\author{
UNIVERSIDADE DE SÃo PAULO \\ FACULdADE DE FILOSOFIA, LETRAS E CIÊNCIAS hUMANAS \\ DEPARTAMENTO dE LETRAS CLÁSSICAS E VERNÁCULAS \\ Programa de pós-graduação em filologia e língua PORTuguesa
}

\title{
Morfologia do VERBo PORTUGUÊs EM OBRAS DE REFERÊNCIA
}

\author{
Maria Elizabeth Leuba Salum \\ Tese apresentada ao Programa de Pós- \\ Graduação em Filologia e Língua Portuguesa, \\ do Departamento de Letras Clássicas e \\ Vernáculas da Faculdade de Filosofia, Letras e \\ Ciências Humanas da Universidade de São \\ Paulo, para obtenção do título de Doutor em \\ Letras.
}

Orientador: Prof. Dr. Valter Kehdi 
Em memória do professor Salum e da professora Flávia Carone, que me apontaram os caminhos com a confiança de que um dia eu encontraria minha vereda. 
Meus agradecimentos,

ao orientador, que, com dedicação e generosidade intelectual, me estimulou a seguir em frente, e

aos familiares e amigos, que, especialmente na fase de redação, aceitaram que eu me furtasse a manter a sempre estreita convivência, que, enfim, se restabelece.

Meu reconhecimento ao Centro de Línguas da FFLCH-USP,

pela oportunidade de trabalho com os alunos de Redação Acadêmica, com as monitoras da área de português e com as colegas educadoras, que vêm compartilhando comigo o exercício da crítica na busca do conhecimento;

pelo favorecimento da minha reentrada na carreira acadêmica, estimulada especialmente pelos membros da coordenação da área de português e da diretoria, bem como pela educadora da área de português a quem eu sucedi, e

pelo apoio oferecido pelos colegas funcionários, monitores e estagiários da área administrativa, que têm permitido o desenvolvimento do meu trabalho profissional. 


\section{Resumo}

Neste estudo, analisou-se o tratamento dado à morfologia verbal do português em três tipos de obras de referência - um estudo de lingüística teórica; nove gramáticas de português, e os verbetes de terminações verbais de um dicionário -, na tentativa de: tornar a descrição mattosiana mais clara para a manipulação didática; verificar em que medida as gramáticas se beneficiam dessa análise; estabelecer possíveis razões para a defectividade em português, e atribuir uma classificação para os verbos com alternância vocálica, baseada no levantamento quantitativo desses verbos.

Assim, a morfologia verbal foi examinada em três textos de Câmara Jr. (1975; 1972; 1970); duas gramáticas de português voltadas para falantes de português como língua materna (Bechara, 1999; Cunha; Cintra, 1985) e em sete gramáticas voltadas para falantes de português como língua estrangeira (Hutchinson; Lloyd, 2002; Perini, 2002; Masip, 2000; Abreu; Murteira, 1998; Gärtner 1998; Teyssier, 1984; Vázquez Cuesta; Mendes da Luz, 1980).

Os resultados da pesquisa mostram que a descrição mattosiana está no bojo de exposição da morfologia das duas primeiras gramáticas, mas poderia ser mais explorada na exposição didática. O levantamento dos verbos defectivos em Bechara (1999); Cunha; Cintra (1985) permitiu verificar relação entre a defectividade verbal e uma possível alternância vocálica nos verbos de terceira conjugação. Apesar da descrição pouco econômica, o estabelecimento de verbetes de Houaiss; Villar (2001a; 2001b) favoreceu o levantamento quantitativo dos verbos com alternância vocálica, fazendo ver que o fenômeno ocorre na maioria dos verbos com vogais radicais /e/ e /o/ das três conjugações.

Palavras chave: alternância vocálica, defectividade, estrutura verbal, gramáticas de PLE, verbetes de terminações verbais 


\begin{abstract}
In this study, the treatment given to the verb Portuguese morphology was analyzed in three types of reference books - theoretical linguistic study; nine grammar books in Portuguese and the dictionary entries of verb endings -, in the attempt of: making clearer Joaquim Mattoso Câmara Jr. description for didactic usage; of verifying to what extent the grammar books take advantage of this analysis; of establishing possible reasons for the defectiveness in Portuguese and of classifying the verbs with vowel variation based on these verbs' quantitative survey.

This way the verb morphology was examined in three Câmara Jr. texts (1975; 1972; 1970); two Portuguese grammar books directed to Portuguese learners viewing this language as a mother-tongue $(1975 ; 1972 ; 1970)$; and in seven grammar books directed to Portuguese learners viewing it as a foreign language. $(1975 ; 1972 ; 1970)$.

The results of this study reveal that Joaquim Mattoso Câmara Jr. description is in the core of the morphology exposure in the two former grammar books, but that it also could be better exploited in the didactic usage. The defective verbs survey in Bechara $(1999,1975)$; Cunha; Cintra (1985) made it possible to verify the relation between the verb defectiveness and a probable vowel variation in the third inflection verbs. Despite a brief description, the entries's setting found in Houaiss; Villar (2001a; 2001b) made it possible the quantitative survey of verbs with vowel variation showing that the phenomenon takes place in most part of verbs with root vowels /e/ and /o/ in the three inflections.
\end{abstract}

KEY-WORDS: vowel variation, defectiveness, verbal strucutur, grammar to foreigners studentes, verbal ending entries 



\section{SuMÁRIO}

INTRODUÇÃ

CAPÍTULO 1

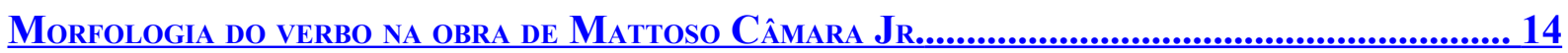

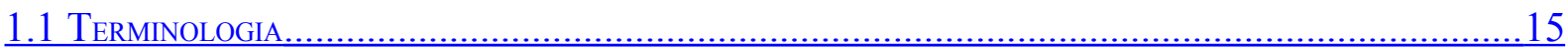

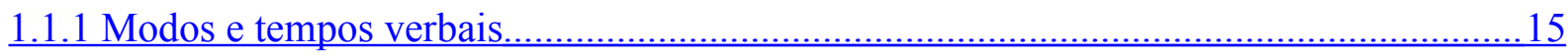

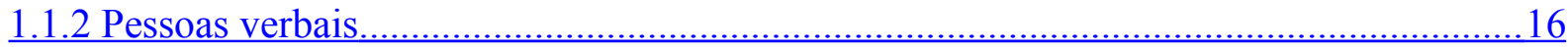

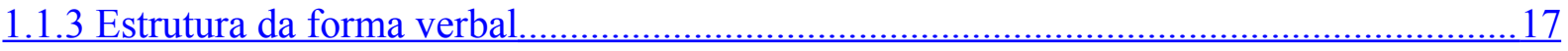

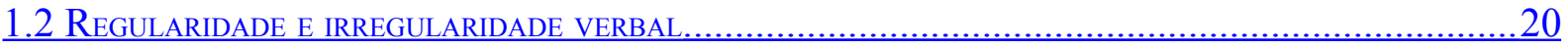

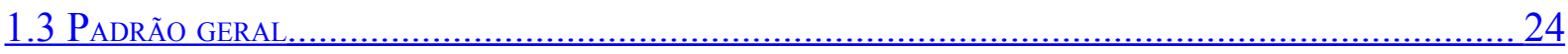

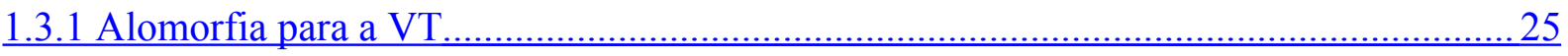

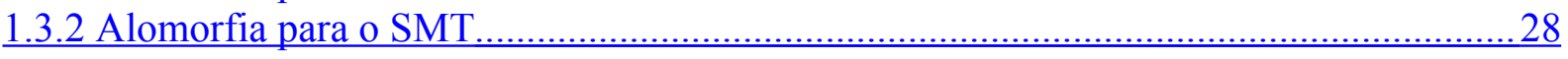

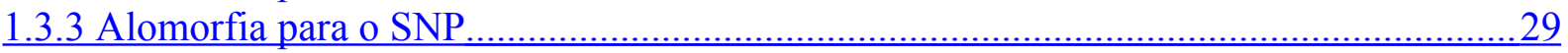

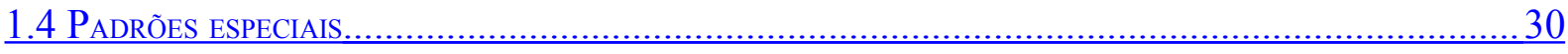

1.4.1 Padrões especiais para o grupo do presente ......................................................... 31

1.4.1.1 Primeiro padrão: verbos da primeira conjugação com alternância vocálica..................32

1.4.1.2 Segundo padrão: verbos das segunda e terceira conjugações com alternância vocálica

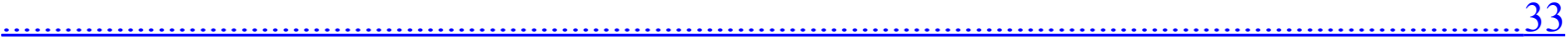

1.4.1.3 Terceiro padrão: verbos com alterações no RI em SbPr........................................... 34

1.4.2 Padrão especial para o grupo do perfeito............................................................. 36

1.4 .3 Padrão especial para o particípio.......................................................................... 38

1.5 PARTICUlARIDAdES NA ESTRUTURA DOS VERBOS MONOSSILÁBICOS................................................ 41

1.5.1 Desvios no terceiro padrão especial para o grupo do presente................................... 41

1.5 .2 Desvios no padrão especial para o grupo do perfeito............................................. 44

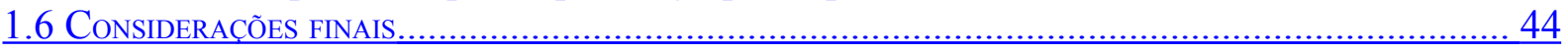

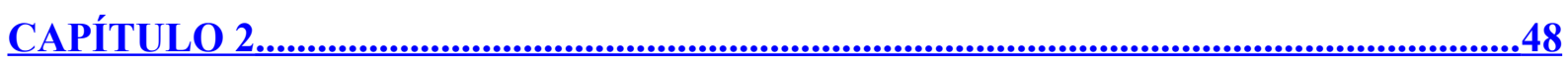

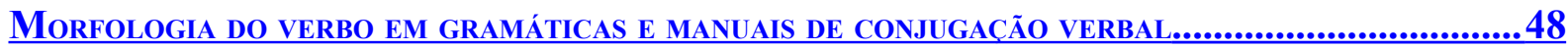

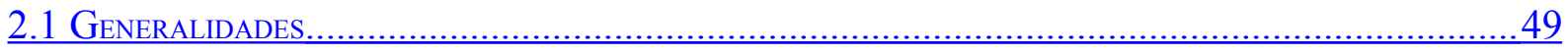

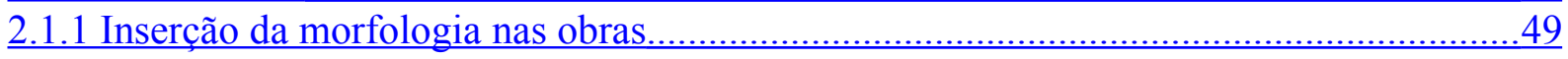

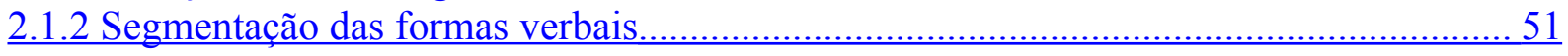

2.1.3 Regularidade, irregularidade e outras classificações para os verbos.............................. 54

2.2 CONJUGAÇ̃̃O DOS VERBOS REGULARES, AUXILIARES, ANÔMALOS E IRREGULARES ...........................56

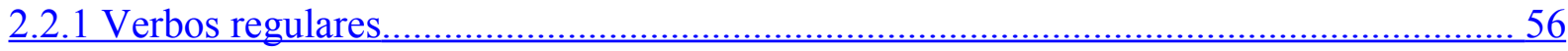

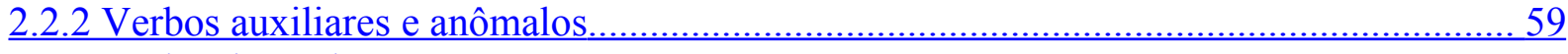

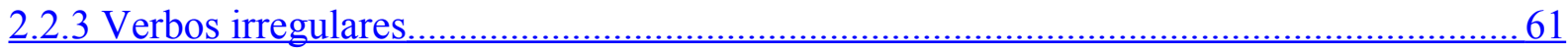

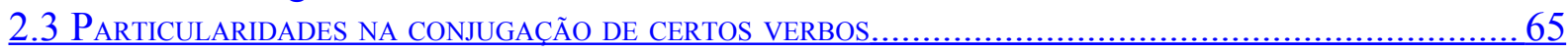

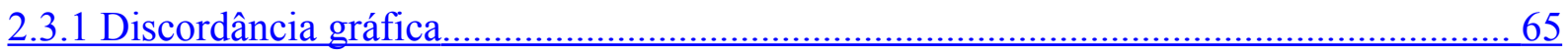

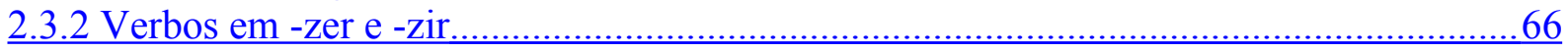

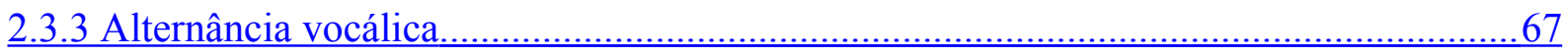




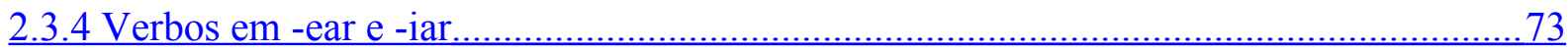

2.3.5 Verbos em -guar/-quar e -güir/-qüir........................................................................

2.3.6 Outros casos........................................................................................... 77

2.4 VERBOS DEFECTIVOS...................................................................................... 79

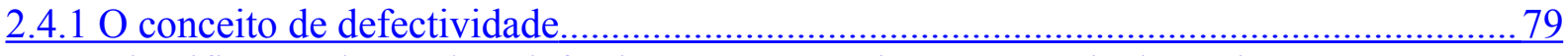

2.4.2 Classificacção dos verbos defectivos nas gramáticas e manuais de conjugação................. 81

2.4.3 Tentativa de identificação das razões para a defectividade verbal nos verbos examinados

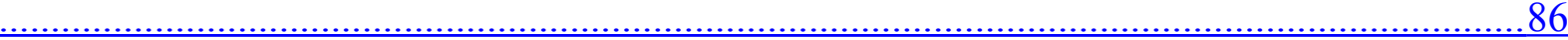

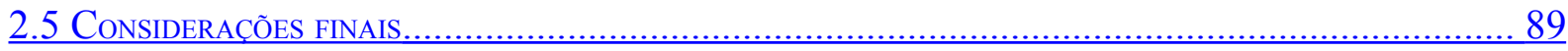

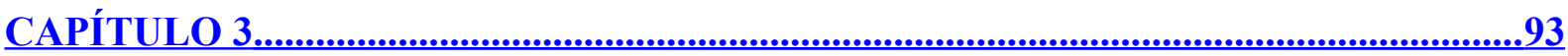

Morfologia do verbo no Dicionário Houaiss da língua portuguesa..........................................93

3.1 A TERMINOLOGIA........................................................................................................94

3.1.1 Uso de terminação e sufixo........................................................................................94

3.1.2 Uso de padrão, paradigma, modelo e grupo...................................................................97

3.1.3 Uso de abundante, co-regular, defectivo, irregular e regular na qualificação dos verbos

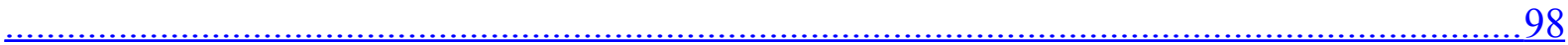

3.1.4 Uso de radical do perfeito, formas rizotônicas e arrizotônicas........................................ 100

3.1.5 Uso de os, todos e os poucos na quantificação dos verbos............................................ 101

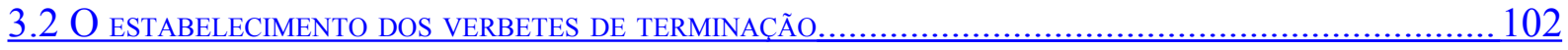

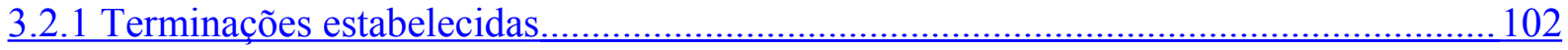

3.2.2 Terminações não-estabelecidas................................................................................104

3.2.3 Terminações que deveriam ter sido estabelecidas em mais de uma entrada...................106

3.2.4 A falta de economia........................................................................................ 109

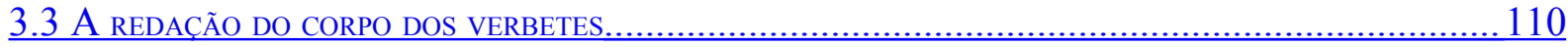

3.3.1 Declaração de regularidade com descrição de particularidades morfológicas................110

3.3.1.1 Redação dos verbetes de terminações correspondentes a verbos de primeira

conjugação com encontros vocálicos no infinitivo............................................................. 112 3.3.1.2 Redação dos verbetes de terminações correspondentes a verbos de primeira e segunda conjugações com discordância gráfica e/ou alternância vocálica.............................................115 3.3.2 Declaração de defectividade ou irregularidade .........................................................120

3.3.3 Descrição de particularidades morfológicas.............................................................. 122

3.3.3.1 Redação dos verbetes de terminações correspondentes a verbos de terceira conjugação com alternância vocálica e/ou defectividade...................................................................... 122 3.3.3.2 Redação dos verbetes de terminações correspondentes a verbos com instabilidade na sílaba tônica do radical..................................................................................................... 125 3.3.3.3 Redação dos verbetes de terminações correspondentes a verbos com outras variações de radical no grupo do presente ....................................................................................... 128 3.3.3.4 Redação dos verbetes de terminações correspondentes a verbos com variações de radical no grupo do presente e de tema no grupo do perfeito................................................. 129 3.3.3.5 Redação dos verbetes com observações estranhas à morfologia verbal..................... 131 3.4 CONSIDERACÕES FINAIS................................................................................................ 131

SÍNTESE DAS CONSIDERAÇÕES FINAIS............................................................................ 134 
Plano de exposiç̃o da morfologia Verbal nas obras nas obras examinadas no Capítulo 2.140

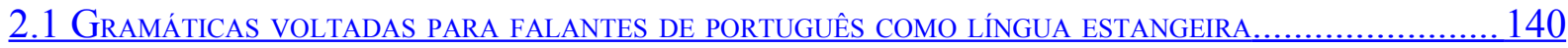

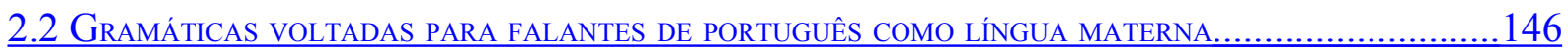

2.3 MANUAIS DE VERBOS.................................................................................. 147

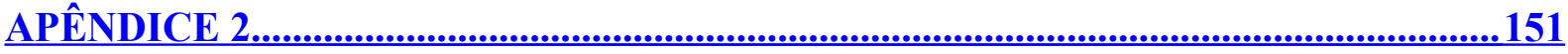

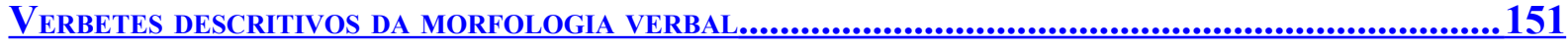

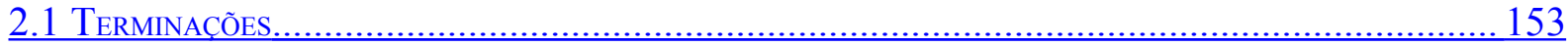

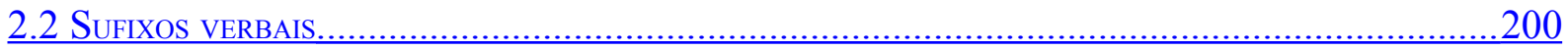

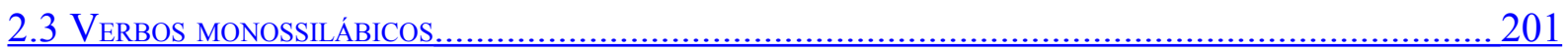

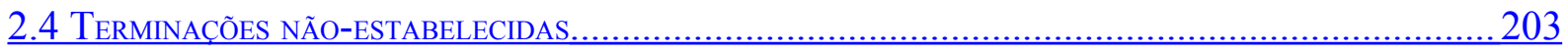

2.4.1 Terminações que corresponderiam a verbos que seriam classificados simplesmente

como regulares.......................................................................................................... 204

2.4.2 Terminações que corresponderiam a verbos que seriam declarados regulares com

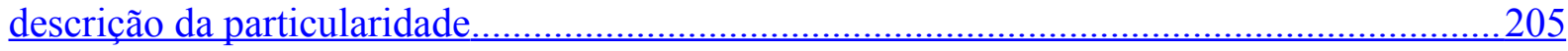

2.4.3 Terminações que corresponderiam a derivados de verbos monossilábicos.................206

2.4.4 Terminações que corresponderiam a verbos de terceira conjugação em que o u é

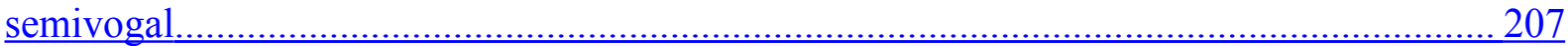

2.4.5 Terminações que corresponderiam a verbos de terceira conjugação em que o u é

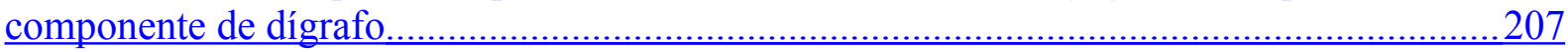

2.4.6 Terminações que corresponderiam a verbos fósseis ou pouco usados....................... 207

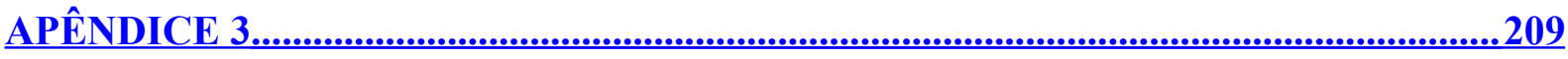

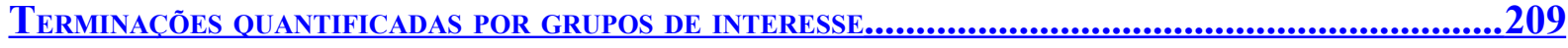

3.1 TERMINAÇÕES CORRESPONDENTES A VERBOS DECLARADAMENTE REGULARES (TOTAL DE 431)...........209

3.2 TERMINAÇÕES CORRESPONDENTES A VERBOS DECLARADAMENTE ABUNDANTES, CO-REGULARES,

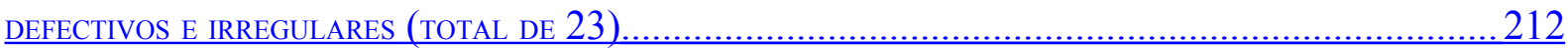

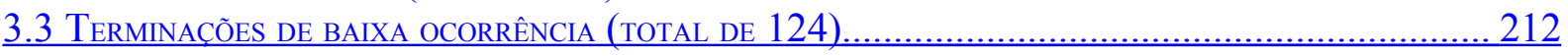

3.4 TERMINACÕES CORRESPONDENTES A VERBOS SIMPLESMENTE CLASSIFICADOS COMO REGULARES (TOTAL DE

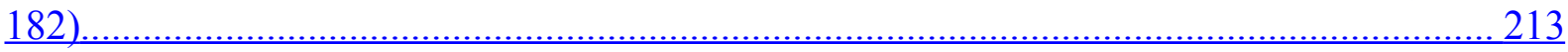

3.5 TERMINACÕES CORRESPONDENTES EXCLUSIVAMENTE A DERIVADOS DE VERBOS MONOSSILÁBICOS (TOTAL

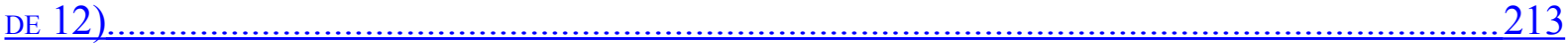

3.6 TERMINACÕES CORRESPONDENTES A VERBOS QUE SEGUEM PARADIGMAS DIFERENTES (TOTAL DE 68)...215

3.7 TERMINACÕES CORRESPONDENTES A VERBOS COM PARTICULARIDADES SEM RELAC̄̃̃O COM A CONJUGAÇ̃̃O

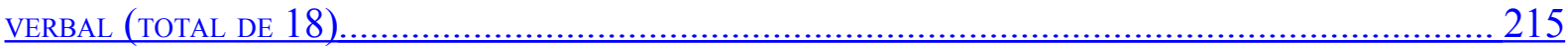

3.8 TERMINAÇÕES CORRESPONDENTES A VERBOS DA PRIMEIRA CONJUGAÇÃO COM DITONGO NO INFINITIVO

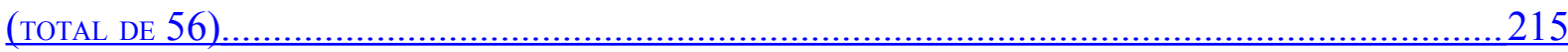


3.9 TERMINAC̄̃̃ES CORRESPONDENTES PARCIALMENTE A VERBOS DA PRIMEIRA CONJUGAÇ̃̃O COM HIATO NO

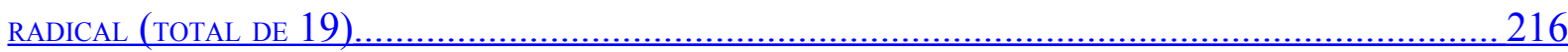
3.10 TERMINACÕES CORRESPONDENTES A VERBOS DE PRIMEIRA E SEGUNDA CONJUGACÕ̃ES COM ALTERNÂNCIA

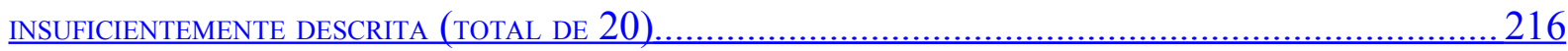
3. 11 TERMINACÕES CORRESPONDENTES A VERBOS DE PRIMEIRA E SEGUNDA CONJUGACÕES EXCLUSIVAMENTE

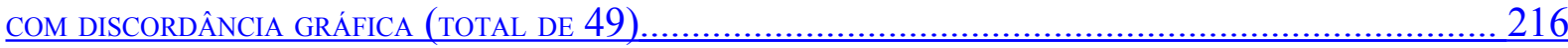
3.12 TERMINACÕES CORRESPONDENTES A VERBOS DE PRIMEIRA E SEGUNDA CONJUGACÕ̃ES EXCLUSIVAMENTE

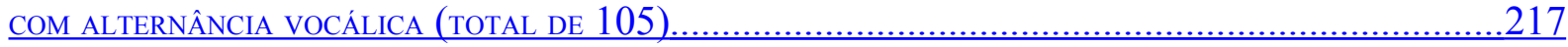
3.13 TERMINACC̃̃ES CORRESPONDENTES A VERBOS DE PRIMEIRA E SEGUNDA CONJUGAÇÕES COM DISCORDÂNCIA GRÁFICA E ALTERNÂNCIA VOCÁLICA AO MESMO TEMPO (TOTAL DE 26).........................................217 3.14 TERMINAÇÕES DE PRIMEIRA CONJUGAÇ̃̃O INICIADAS POR -E E -O COM NÚMERO DE VERBOS (TOTAL DE

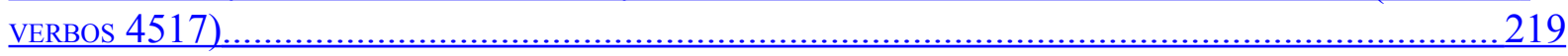
3.15 TERMINAÇ̃̃ES DE SEGUNDA CONJUGAÇ̃̃o INICIADAS POR -E E -O COM NÚMERO DE VERBOS (TOTAL DE

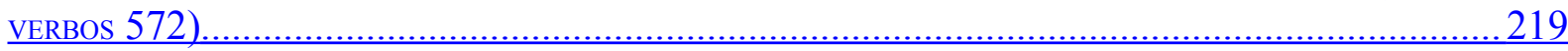
3.16 TERMINAC̄õES CORRESPONDENTES A VERBOS DE TERCEIRA CONJUGACC̃̃O COM ALTERNÂNCIA VOCÁLICA E

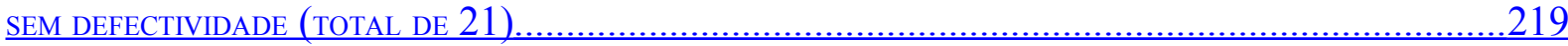
3.17 TERMINAC̄õES CORRESPONDENTES A VERBOS DE TERCEIRA CONJUGAÇ̃̃O COM DEFECTIVIDADE E SEM

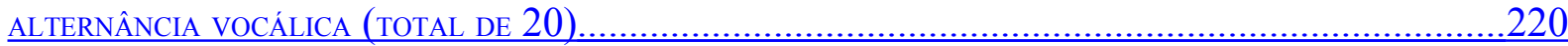
3.18 TERMINAC̄õES CORRESPONDENTES A VERBOS DE TERCEIRA CONJUGACC̃̃O COM ALTERNÂNCIA VOCÁLICA E

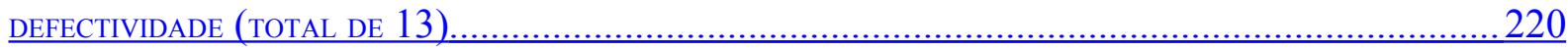
3.19 TERMINACCÕES DE TERCEIRA CONJUGAÇ̃̃O INICIADAS POR -E, -O E -U COM NÚMERO DE VERBOS (TOTAL

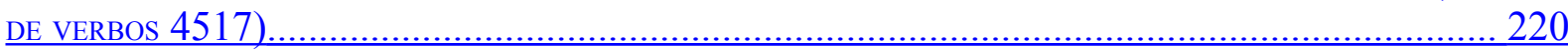
3.20 VERBETES QUE INCLUEM OBSERVAÇÕES ESTRANHAS À MORFOLOGIA VERBAL (TOTAL DE 22)...........220

APÊNDICE 4

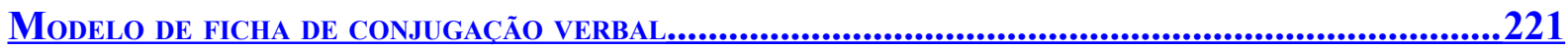

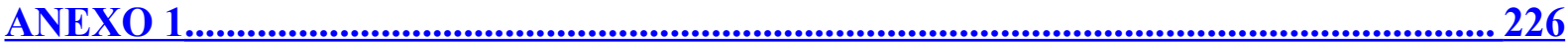

QUADRO PARA OS SUFIXOS MODO-TEMPORAIS NOS VERbOS PORTUGUESES (CÂMARA JR., 1975, P. 146)

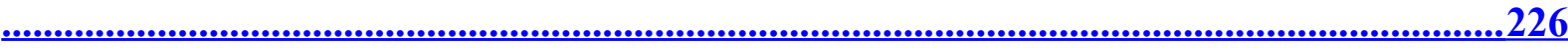

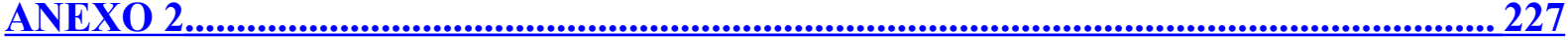

QUADRO PARA OS SUFIXOS NÚMERO-PESSOAIS NOS VERbOS PORTUGUESES (CÂMARA JR, 1975, P. 147)

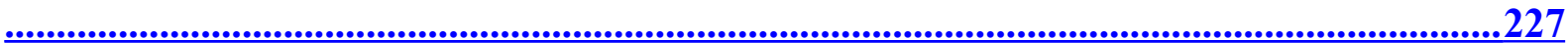




\section{INTRODUÇão}

Este estudo nasceu de uma preocupação didática: a de tornar mais compreensível a morfologia do verbo em português para falantes de língua estrangeira - para quem a memorização das formas verbais é a porta de entrada para a nova língua que precisam ou devem usar. Entende-se a importância que os estrangeiros atribuem ao domínio do sistema verbal - aí incluído o não menos relevante domínio do uso dessas formas, que não será, porém, matéria deste estudo -, pois é a oração, ou seja, a frase organizada em torno de um verbo, "em termos de freqüência, o tipo frasal dominante em português" (Carone, 1986: 512), assim como nas outras línguas derivadas do indo-europeu.

Distribucionalistas americanos não se omitiram com relação ao problema enfrentado pelos estrangeiros, quando ilustraram sua análise em constituintes imediatos da morfologia do inglês. Depois de conceituar morfema como a menor unidade significativa da estrutura da língua, Gleason (1970, p. 55-6) distingue cat, "gato", com significado extralingüístico, de to, cujo significado, lingüístico, se configura apenas por sua distribuição, identificada por meio de comparação de diferentes amostras de uma língua:

[...] Para um estrangeiro, essa distribuição é o traço mais facilmente observável e, daí, a chave principal para seu significado.

Quando se está lidando com sua própria língua, muito disso parece supérfluo. Isso se dá simplesmente porque essas comparações foram feitas repetida e subconscientemente, ou também conscientemente no passado. $[\ldots]^{1}$

Assim, mesmo para os falantes de português como língua materna, apenas parece, mas não é supérflua, a comparação entre as palavras para depreender os morfemas e seus alomorfes, ou seja, suas formas variantes fonologicamente condicionadas. E isso quem faz é o lingüista:

\footnotetext{
${ }^{1}$ No original, "[...] For the foreigner, this distribution is the most easily observable feature of such a morpheme, and hence the chief clue to its meaning. [...] When a person is dealing with his own native language, much of this seems superfluos. This is simply because such comparisons have been made repeatedly ans subconsciously, if not consciously, in the past. [...]"
} 
[...] Como lingüistas, podemos fazer uma descrição de nossos próprios hábitos e, com base nessa definição, fazer a seleção apropriada de forma deliberada. A definição formal só é válida se produz o mesmo resultado que o hábito inconsciente. (Gleason, 1970, p. 62) ${ }^{2}$

É essa, também, a postura de Câmara Jr. (1972, p. 114), quando trata dos verbos irregulares em português:

Este artigo, que visa a uma reformulação do conceito de irregularidade verbal e da maneira de descrevê-la na gramática portuguesa, é em princípio de lingüística teórica e não de lingüística aplicada. Apenas procura lançar naquela os fundamentos em que esta deve assentar.

Ao professor de língua portuguesa é que cabe a manipulação didática da nossa exposição, inclusive a organização de exercícios práticos, baseados nas oposições e correlações formais que aqui se apresentam.

A sugestão, lançada na década de 1960, parece não ter sido acolhida pela maioria dos autores de gramáticas, especialmente as voltadas para falantes de português como língua estrangeira, que, quando muito, permitem que o novo usuário da língua distinga o radical do verbo (o morfema de significação extralingüística) das chamadas terminações (os morfemas lingüísticos, definidos pela distribuição), que engessam os constituintes da forma verbal portuguesa, escondendo-lhes as articulações.

Também em alguns manuais de conjugação verbal, destacam-se as terminações, mas a apresentação dos tempos verbais (do indicativo e, depois, do subjuntivo, seguidos das formas do imperativo, infinitivo, gerúndio e particípio) impede que se perceba a distribuição, entre os tempos e modos verbais, das variantes do radical de um mesmo verbo. O usuário da língua não visualiza, p.ex., que o radical do pretérito perfeito do indicativo se repete em outros três tempos: no mais-que-perfeito mesmo modo, no pretérito imperfeito e no futuro do subjuntivo, conjugados em seções diferentes.

É bem verdade que, sozinho, ele pode fazer a comparação, mas - lembrando o que diz o lingüista americano - nem sempre com consciência. Por isso, os menos atentos sentem como arbitrária a distribuição dos morfemas verbais e acabam por render-se à tirania, repetindo a conjugação verbal completa - por escrito ou oralmente - até memorizá-la, ou então rebelam-se contra a suposta tirania, menosprezando a importância da flexão verbal, e mesmo da variação no radical, que é evidente na comparação de certas formas verbais.

\footnotetext{
${ }^{2}$ No original, "[...] As linguist we may formulate a descriptive statement of our own habits and on the basis of this statement is valid only insofar as it produces the same result as the subconscious habit of the native speaker."
} 
Neste estudo, o objetivo é examinar a morfologia verbal em obras de referência - uma obra de lingüística teórica; nove gramáticas e um dicionário -, procurando

- reorganizar as idéias de Câmara Jr. (1975; 1972; 1970), com base no cotejo de seus principais textos sobre o tema, na tentativa de torná-las mais claras para a "manipulação didática";

- comparar o tratamento do tema em gramáticas de português voltadas para falantes de português como língua materna (Bechara, 1999; Cunha; Cintra, 1985), e como língua estrangeira (Hutchinson; Lloyd, 2002; Perini, 2002; Masip, 2000; Abreu; Murteira, 1998; Gärtner, 1998a; Teyssier, 1984; Vázquez Cuesta; Mendes da Luz, 1980), na tentativa de avaliar em que medida se beneficiam da análise mattosiana;

- fazer o levantamento dos verbos defectivos listados nas duas primeiras gramáticas, e incluídos em manuais de conjugação (Lopes, 1992; Rodrigues, 2003; Ryan, 1991), na tentativa de estabelecer possíveis as razões da defectividade, e

- comparar a redação dos verbetes de terminações verbais, estabelecidas por Houaiss; Villar (2001a; 2001b), na tentativa de verificar o tratamento dado aos verbos não declaradamente regulares, e fazer o levantamento quantitativo dos verbos com alternância vocálica em português.

A escolha dessas obras não foi aleatória. De reconhecida importância, a descrição da morfologia verbal de Câmara Jr. $(1975 ; 1972$; 1970) foi retomada em pesquisas acadêmicas de relevância para este estudo (Kehdi, 1998; Santos, 1989; Luft, 1976; Pontes, 1972). ${ }^{3}$

Em tese de livre-docência ainda não publicada, Kehdi (1998) analisa e interpreta os estudos do lingüista, nos campos da morfologia e da sintaxe portuguesa, dedicando um capítulo à flexão verbal. Propõe que "o próprio quadro mattosiano da flexão verbal sugere possibilidades de reformulação e correção, o que não lhe tira o caráter de referencial básico" (Kehdi, 1998, p. 226). Sua constatação de que "a vogal temática também acumula valores modo-temporais e número-pessoais" será comentada no Capítulo 1.

\footnotetext{
${ }^{3}$ Outros autores, cuja contribuição não foi relevante para este estudo, valeram-se também da análise mattosiana,: Zanotto (1991), em obra de divulgação para estudantes de cursos universitários; Pagliarini (1978), em dissertação sobre morfofonologia das formas verbais finitas; Eastlack (1964), em dissertação sobre morfologia do verbo em português. Sem mencionar os estudos do lingüista brasileiro, Giurescu (1976) propõe uma classificação dos verbos em português com base em sincretismos entre as formas verbais (infinitivo = futuro do subjuntivo).
} 
Em dissertação de mestrado igualmente não publicada, Santos (1989, p. 137) ressalta a importância da distinção feita pelo lingüista "no que respeita à distinção e à autonomia entre as classes de verbos impessoais, unipessoais e defectivos" - o que já faz ver que o eixo de seu estudo é a questão do uso, tema a que se fará referência no Capítulo 2.

Em dissertação para concurso de livre-docência, já publicada, Luft (1976) propõe um modelo, em forma de "diagramas-árvore", de análise morfológica das formas verbais e nominais de análise depois de retomar, dentre outras, a "análise pioneira de Joaquim Mattoso Câmara Jr.". Fazendo a ela alguns "reparos", dentre os quais se considera relevante o questionamento, a ser mencionado no Capítulo 1, sobre a análise de formas nominais de acordo com uma estrutura, proposta por Câmara Jr. (1975, 1972, 1970), que prevê sistematicamente a presença de um sufixo número-pessoal.

Em publicação resultante de dissertação de mestrado, Pontes (1972) apóia-se, também, na análise mattosiana, propondo algumas alterações na estrutura verbal do verbo em português estabelecida pelo lingüista. Neste estudo, discute-se sua posição em relação à vogal temática, considerada pela autora como integrante do sufixo flexional, conforme se verá no Capítulo 1.

Além disso, os trabalhos de Joaquim Mattoso Câmara Jr. são citados em boa parte das gramáticas que foram examinadas neste estudo: duas gramáticas voltadas para falantes de português como língua materna (Bechara, 1999; Cunha; Cintra, 1985) e sete voltadas para falantes de português como língua estrangeira (Hutchinson; Lloyd, 2002; Perini, 2002; Masip, 2000; Abreu; Murteira, 1998; Gärtner 1998; Teyssier, 1984; Vázquez Cuesta; Mendes da Luz, 1980).

A escolha das obras escritas em outras línguas foi determinada pela facilidade de acesso às publicações e aos textos nas línguas cuja estrutura gramatical se conhecia em maior ou menor profundidade. Além disso, procurou-se trabalhar com material editado ou reeditado nas duas últimas décadas do século XX cujos autores tivessem expressão no meio acadêmico. Seis delas são destinadas a falantes de:

- alemão, a Grammatik der portugiesischen Sprache, de Eberhard Gärtner, professor de Romanística na Universidade de Leipzig; 
- espanhol, a Gramática portuguesa, das professoras Pilar Vázquez Cuesta e Maria Albertina Mendes da Luz, obra de consulta nas faculdades de Letras portuguesas em cursos para portugueses e estrangeiros;

- francês, o Manuel de langue portugaise Portugal-Brésil, de Paul Teyssier, professor da Universidade de Paris-Sorbonne;

- inglês, a Modern Portuguese: A Reference Grammar, de Mário Perini, professor visitante do Departamento de Letras Modernas da Universidade do Mississipi, e Portuguese. An Essential Grammar, de Hutchinson; Lloyd, 2002), de Amélia P. Hutchinson e Janet Lloyd, leitoras de português na Universidade de Salford em Oxford, e

- italiano, a Grammatica del portoghese moderno de Maria Helena Abreu e Rita Benamor Murteira, professoras de português na Universidade de Pisa. ${ }^{4}$

A sétima gramática, também destinada a falantes de português como língua estrangeira, mas publicada no Brasil, é de Vicente Masip, coordenador do curso de Licenciatura em Língua Portuguesa e Espanhola na Universidade Federal de Pernambuco, na época da publicação.

Nas referências bibliográficas de todas elas, está a Nova gramática do português contemporâneo (Celso Cunha; Lindley Cintra, 1985), ou então a edição que lhe serviu de base: a Gramática do português contemporâneo, de Celso Cunha, editada pela Bernardo Álvares. Provavelmente por ser menos conhecida fora do Brasil, a Moderna gramática portuguesa (Bechara, 1999), edição revista e ampliada da Moderna gramática da língua portuguesa. Cursos de $1^{\circ}$ e $2^{\circ}$ graus, é citada apenas por Masip (2000).

Os dois primeiros autores são também citados nos manuais de conjugação verbal usados neste trabalho (Rodrigues 2003; Lopes; 1992; Ryan, 1991),: Vera Cristina Rodrigues é responsável pelas tábuas de conjugação de Houaiss; Villar (2001a); João Antunes Lopes faz, na introdução de seu manual, considerações importantes sobre a questão dos verbos defectivos, e Maria Aparecida Ryan, professora da Universidade de Georgetown, revela preocupação evidente com o domínio da morfologia verbal do português por parte de falantes não-nativos.

\footnotetext{
${ }^{4}$ As indicações sobre a atuação acadêmica dos autores correspondem à época de publicação de cada uma das próprias obras, já que foram obtidas em prefácios ou quartas capas.
} 
Optou-se pelo levantamento de dados em Houaiss; Villar (2001a) pelo fato de, na época em que se iniciou a pesquisa, ser ele o único dicionário disponível em versão eletrônica - o que permitiu levantar os verbetes com mais precisão do que caso se tivesse utilizado a versão impressa.

A análise fará ver que a exposição encontrada nas gramáticas está a pedir reformulação, como adverte Câmara (1970, p. 101):

[...] A enumeração desses verbos [ditos 'irregulares'] em 'ordem alfabética' (isto é, por um critério ordenador externo e superficial) deve ceder lugar a novo tratamento descritivo. Ainda aqui é preciso fugir da memorização pura e simples, que é o mais inconveniente meio de aprender. Na realidade, o estudante com ela só aprende afinal, porque consegue entrever um pouco, embora intuitivamente, as relações e coincidências que a enumeração alfabética convencional está encobrindo.

Pela própria natureza, os manuais de conjugação também não contribuem para o estabelecimento dessas relações: multiplicam-se os modelos de conjugação, com relevância para características que não são privativas da categoria do verbo (discordância gráfica, p.ex.).

Em seu dicionário, numa descrição tanto ou mais dispendiosa, Houaiss; Villar (2001a; 2001b) estabelecem como verbetes pouco menos de seiscentas "terminações", que aglutinam quatro elementos distintos - a última vogal do radical (livre ou travada por consoante ou semivogal), a vogal temática, o sufixo modo-temporal e o sufixo número-pessoal -, o que obscurece a descrição feita por Câmara Jr. (1975; 1972, 1970).

É preciso notar que a exposição do lingüista, especialmente nos textos publicados postumamente, fica muitas vezes comprometida por problemas de edição de texto - o que não interfere substancialmente na discussão, admirável, da estrutura dos verbos com a chamada irregularidade de radical. Com muita propriedade, descreve as alternâncias vocálicas especialmente nas segunda e terceira conjugações, mas não dá exatamente solução à classificação desses verbos, que tende a considerar regulares. Percebe-se essa hesitação por marcas implícitas na redação.

Isso aponta para a discussão que se fará, ao longo deste estudo, sobre a classificação desse grupo de verbos em regulares ou irregulares, que não fica clara nas gramáticas e no próprio dicionário. Neste último, a indefinição sobre a classificação é ainda mais acentuada, pois estende-se aos verbos com discordância gráfica, não havendo, em geral, nos verbetes correspondentes aos verbos ditos tradicionalmente "anômalos", "abundantes" e "defectivos" descrição, e não classificação. 
Nas gramáticas, os rótulos lá estão e, por isso, não se pode dizer que há propriamente questionamento, mas hesitação na classificação de verbos com alternância vocálica, e dos verbos que apresentam mais de uma forma por oscilação na sílaba tônica (como adequar ou mobiliar) ou por ditongação da vogal radical (como negociar). Não se tratará especialmente dos verbos com duplo particípio, que serão examinados apenas de acordo com a descrição de Câmara Jr. (1970).

Para tentar entender o comportamento dos verbos defectivos - de que não se ocupa Câmara Jr. (1975; 1972; 1970) -, as gramáticas e manuais acabam oferecendo soluções muitas vezes conciliatórias, que agradam a gregos e troianos, ou contraditórias, que não agradam a ninguém. De toda forma, será possível verificar, em verbos da terceira conjugação, estreita relação entre defectividade e possível alternância vocálica.

Ainda que o estabelecimento das terminações de Houaiss; Villar (2001a; 2001b) não mereça críticas do ponto de vista da redação e edição de texto, ressalta-se a importância do trabalho dos lexicógrafos, sem o qual não teria sido possível fazer o levantamento quantitativo dos verbos de primeira e segunda conjugações com vogais radicais /e/ e /o/ no infinitivo, bem como de terceira conjugação com essas mesmas vogais e também com a vogal /u/ - o que revelou predomínio absoluto desse grupo de verbos no português, com tendência, portanto, à regularidade.

Este estudo está organizado em quatro partes:

- Capítulo 1 - Morfologia do verbo na obra de Mattoso Câmara JR., onde se expõe a análise da estrutura do verbo português, propondo-se uma reorganização, ligeiramente diferente, dos verbos com variação de radical.

- Capítulo 2 - Morfologia do verbo nas gramáticas e manuais de conjugação verbal, onde se discute a apresentação da morfologia verbal feita nas gramáticas e a apresentação de verbos defectivos, abundantes e com oscilação no acento, com base no registro de Bechara (1999); Cunha; Cintra (1985); Rodrigues (2003); Lopes (1992); Ryan (1991).

- Capítulo 3 - Morfologia do verbo no Dicionário Houaiss da língua portuguesa, onde se analisa o conjunto dos verbetes de terminações verbais, descrevendo os diferentes tipos de alternância vocálica, com avaliação de freqüência do fenômeno nesse grupo de verbos. 
- SínteSE das CONSIDERAÇões FinAis, onde serão retomadas as considerações finais de cada um dos três capítulos, com uma proposta de apresentação didática da estrutura verbal, e dos padrões do verbo em português, discutidos no Capítulo 1.

Foram organizados quatro apêndices:

- ApÊndice 1 - Plano de exposição da morfologia Verbal nas obras examinadas no Capítulo 2.

- Apêndice 2 - Verbetes descritivos da morfologia verbal examinados no Capítulo 3.

- Apêndice 3 - TerminaÇões quantificadas por grupos de interesse, referidas no Capítulo 3.

- Apêndice 4 - Modelo de ficha de morfologia verbal para aplicaÇão didática. 


\section{Capítulo 1}

\section{Morfologia do verbo na obra de Mattoso Câmara Jr.}

Os estudos do autor sobre a estrutura verbal estão listados, aqui, pela ordem de publicação, e não necessariamente da edição consultada:

- “O verbo em português” (Câmara Jr., 1975).

- "Para o estudo descritivo dos verbos irregulares" (Câmara Jr., 1972), ${ }^{5}$

- “A flexão verbal portuguesa: o padrão geral" e "Os padrões especiais dos verbos em português" (Câmara Jr., 1970), e

- “A análise da flexão verbal” (Câmara Jr., 1969).

Além desses, há ainda outros textos sobre a morfologia verbal, cujas idéias estão presentes nos quatro estudos: "A alternância portuguesa fui : foi" (Câmara Jr., 2004) e os verbetes irregularidade, forma primitiva, defectivos e particípios (Câmara Jr., 1968). ${ }^{6}$

Segundo Kehdi (1998, p. 106-7), nos quatro primeiros textos, "o autor apresenta, basicamente, os mesmos resultados", mas o "estudo mais substancial" está em Câmara Jr. (1972). De fato, o conteúdo deste artigo repete informações dos textos anteriores - seja de Câmara Jr. (1969, p. 66), onde o autor examina apenas a estrutura dos "verbos regulares, estudando as suas regras de flexão nas três conjugações", seja de Câmara Jr. (1970), onde estabelece as siglas usadas em Câmara Jr. (1972).

Embora Câmara Jr. (1975) faça considerações de ordem diacrônica, pela própria natureza da obra (História e estrutura da língua portuguesa), aqui, como nos outros textos, o lingüista propõe "uma nova orientação, com uma análise mórfica bem elaborada, que faça ver os constituintes elementares da forma verbal”, no plano sincrônico (Câmara Jr, 1975, p. 96).

Este capítulo está organizado em seis partes:

\footnotetext{
${ }^{5} \mathrm{O}$ artigo foi "transcrito da revista de Estudos Lingüísticos (Revista Brasileira de Lingüística Teórica e Aplicada), S. Paulo, Centro de Lingüística Aplicada do Instituto de Idiomas Yázigi, 1 (1): 16-27, 1966)”.

${ }^{6} \mathrm{O}$ texto "A alternância portuguesa fui : foi" teve sua primeira publicação em 1939, na Revista de Filoplogia Hispânica, ano I, vol. 3. É este último estudo que aqui se transcreve com leves acréscimos.” (Câmara Jr., 2004, 285).
} 
- $\quad$ 1.1 Terminologia, onde serão explicitadas as siglas usadas pelo autor e comentadas as observações de Luft (1976) a esse respeito.

- 1.2 Regularidade E iRRegularidade verbal, onde se mostrará a hesitação do autor na fixação dos dois conceitos.

- 1.3 PADRão Geral, onde se exporá a análise mórfica feita pelo autor para os verbos que mantém o radical do infinitivo invariável em todas as formas.

- 1.4 PADRÕES ESPECIAIS, onde será dada uma organização ligeiramente diferente da do autor aos verbos que, em algumas formas, fogem ao padrão geral.

- 1.5 Particularidades NA EStrutura dos verbos monossilábicos, onde serão organizadas algumas informações sobre o dos verbos em questão.

- $\quad$ 1.6 CONSIDERaÇões Finais.

Foram utilizados os símbolos fonéticos do IPA (2005), que nem sempre coincidem com os reproduzidos nas citações de Câmara Jr. (1975, 1972, 1970).

\subsection{Terminologia}

Primeiramente, serão retomadas as siglas com que Câmara Jr. (1975, 1972,1970, 1969) distingue os modos e tempos, e as pessoas verbais, bem como dos elementos de sua fórmula representativa da estrutura verbal. Em seguida, será feita uma discussão sobre o uso de padrão geral e padrões especiais para a classificação dos verbos, termos que, muitas vezes, estão relacionados com o conceito de regularidade e irregularidade.

\subsubsection{Modos E TEMPos Verbais}

Como em Câmara Jr. (1975), o autor não usa sigla de nenhuma natureza e, em Câmara Jr. (1969), propõe siglas para as três conjugações (CI, CII e CIII) que já não figuram nos textos posteriores, serão utilizadas, aqui, apenas as siglas para os modos e tempos (Câmara Jr., 1972; 1970), como reproduzidas no Quadro 1.1. 


\section{Quadro 1.1 - Siglas Para os MOdOS E TEMPOS}

\begin{tabular}{|l|l|l|l|}
\hline modos e formas nominais & tempos \\
\hline indicativo & $\mathbf{I d}$ & presente & $\mathbf{P r}$ \\
\hline imperativo (subjuntivo não subordinado) & $\mathbf{S b} \mathbf{b}_{1}$ & pretérito imperfeito & $\mathbf{P t}_{1}$ \\
\hline subjuntivo (subjuntivo subordinado) & $\mathbf{S b} \mathbf{b}_{2}$ & pretérito perfeito & $\mathbf{P t}_{2}$ \\
\hline infinitivo & $\mathbf{I f}$ & pretérito mais-que-perfeito & $\mathbf{P t}_{3}$ \\
\hline gerúndio & $\mathbf{G d}$ & futuro do presente & $\mathbf{F t}_{1}$ \\
\hline particípio & $\mathbf{P a}$ & futuro do pretérito & $\mathbf{F t}_{2}$ \\
\hline
\end{tabular}

Opondo o subjuntivo e o imperativo ao indicativo, Câmara Jr (1970) lembra que, naqueles, o falante toma uma posição subjetiva, não assinalada no indicativo. Daí ter estabelecido uma sigla única para os dois primeiros modos $(S b)$.

Imperativo $\left(\mathrm{Sb}_{1}\right)$ e subjuntivo $\left(\mathrm{Sb}_{2}\right)$, por sua vez, opõem-se pelo fato de o primeiro não ser sintaticamente subordinado e o segundo ser subordinado a um advérbio ou a um verbo da oração principal.

Como o imperativo em português só tem formas de presente, o autor nem sempre atribui o número 2 à sigla $\mathrm{Sb}$ na indicação do modo subjuntivo quando acompanhada da sigla do tempo: $\mathrm{Sb}_{2} \mathrm{Pr}, \mathrm{Sb}_{2} \mathrm{Pt}$ e $\mathrm{Sb}_{2} \mathrm{Ft}$ (Câmara Jr., 1970), ou simplesmente $\mathrm{SbPr}$, SbPt e $\mathrm{SbFt}$ (Câmara Jr., 1972).

Neste trabalho, usando-se a sigla $\mathrm{SbPr}$ em referência ao presente do subjuntivo, em geral não serão levadas em conta as formas do imperativo, que se confundem com as do subjuntivo "no verbo negativo e mesmo no afirmativo, fora da $2^{\mathrm{a}}$ pessoa gramatical do singular e a $2^{\mathrm{a}}$ pessoa do plural ou $5^{\mathrm{a}}$ pessoa, que só aparece nos verbos portugueses em registros especiais da língua escrita" (Câmara Jr., 1970, p. 92).

\subsubsection{Pessoas verbais}

As formas flexionadas também recebem siglas - P1, P2 e P3, para as três pessoas do singular; P4, P5 e P6, para as três pessoas do plural -, às quais se juntam as siglas dos modos e tempos: P4, P5 do IdPr, p.ex. (Câmara Jr., 1970), ou simplesmente 4,5 IdPr, p.ex. (Câmara Jr., 1972). ${ }^{7}$

\footnotetext{
${ }^{7}$ Em Câmara Jr. (1975), o autor fala ainda em $1^{\mathrm{a}}, 2^{\mathrm{a}}, 3^{\mathrm{a}}$ pessoas do singular e do plural - o que comprova ser este texto de produção anterior ao dos outros três.
} 
O estabelecimento de seis pessoas (e não três) decorre do fato de que pessoa gramatical e pessoa do discurso são duas coisas distintas, como observa Câmara Jr. (1970, p. 74) quando trata do mecanismo da flexão portuguesa:

Em português, o falante pode assinalar que está associado a si outra ou outras pessoas $\left(1^{\mathrm{a}}\right.$ pessoa do plural ou $4^{\mathrm{a}}$ pessoa), ou que está se dirigindo a mais de um ouvinte ( $2^{\mathrm{a}}$ pessoa do plural ou $5^{\mathrm{a}}$ pessoa), ou que a referência à $3^{\mathrm{a}}$ pessoa do plural ou $6^{\text {a }}$ pessoa). $[\ldots]^{8}$

Tratando da dêixis, Lyons (1979: 292) faz uma observação muito semelhante à do lingüista brasileiro sobre a questão do número nos pronomes pessoais:

[...] O pronome nós / we deve ser interpretado como eu / I somado a uma ou mais outras pessoas, e as outras pessoas podem ou não incluir o ouvinte. Em outras palavras, nós / we não é o plural de eu / I: inclui antes uma referencia a eu / I e é plural.

Se, nos nomes - e nos pronomes de terceira pessoa do discurso -, o número pode ser uma multiplicação de um mesmo elemento; nos pronomes de primeira e segunda pessoas, a relação é necessariamente de adição. Isso está fundamentado no que expôs Benveniste (1966, p. 233-5), quando distingue a "pessoa" (“eu” e "tu”) da "não-pessoa”, e o "eu” do "não-eu” e mostra que o plural é marca a falta de limitação, e não a multiplicação.

Neste estudo, quando em referência a uma ou mais pessoas isoladas de um determinado tempo, serão usados apenas o(s) número(s) (1,3,4,6 IdPr, p.ex) e, em referência a todas as formas do tempo, serão omitidos os números (SbPr, p.ex.).

\subsubsection{Estrutura da FORMa VERBAL}

Além das usadas para os modos e tempos, de um lado, e para as formas flexionadas, de outro, o lingüista também usa siglas para representar a estrutura da forma verbal:

$$
\mathrm{T}(\mathrm{R}+\mathrm{VT})+\mathrm{SF}(\mathrm{SMT}+\mathrm{SNP})
$$

Segundo essa fórmula - em todos os modos e tempos, bem como nas formas nominais -, ao tema (formado de radical e vogal temática) segue-se o sufixo flexional (formado de sufixo modo-temporal e sufixo número-pessoal).

Com justeza, Luft (1976, p. 54) critica "a análise das formas verbo-nominais sob o domínio do símbolo SMT (sufixo modo-temporal)", especialmente no caso do particípio e

\footnotetext{
${ }^{8}$ No último segmento do período, há no texto original um salto. O autor deve ter querido dizer algo como: “ou que faz referência a mais de um ser, animado ou inanimado ( $3^{\mathrm{a}}$. pessoa do plural ou $6^{\mathrm{a}}$. pessoa)."
} 
gerúndio, pois "a anexação das desinências de número e pessoal [...] só é possível no caso excepcional (idiotismo) do 'infinitivo pessoal' ".

Ainda assim, esse problema pode ser resolvido se, na fórmula, for incluída uma indicação de que pode não haver SF, justamente quando as formas tiverem caráter "verbonominal", como prefere Luft (1976): T $(\mathrm{R}+\mathrm{VT})+\mathrm{SF}(\mathrm{SMT} \pm \mathrm{SNP})$. Simplificada, a estrutura do particípio e do gerúndio ficaria reduzida a $\mathrm{R}+\mathrm{VT}+\mathrm{SMT}$.

Em Câmara Jr. (1970), à sigla R, opõem-se R', para o radical do perfeito, e $\mathrm{R}_{1}$, para a variação de radical em SbPr e 1 IdPr. Câmara Jr. (1972, p. 107) distingue o "radical de perfeito (RP)" - ou seja, de $\mathrm{IdPt}_{2}, \mathrm{IdPt}_{3}, \mathrm{Sb}_{2} \mathrm{Pt}, \mathrm{Sb}_{2} \mathrm{Ft}$ - do "radical de imperfeito (RI)".

Essa oposição já era feita pelos gramáticos latinos, que dividiam as formas verbais, do ponto de vista aspectual, em "dois grandes grupos, que chamavam, respectivamente, de perfectum 'perfeito' (isto é, feito cabalmente, concluso) e do infectum 'não feito (cabalmente)', isto é, 'imperfeito, ou inconcluso' (Câmara Jr., 1975, p. 127).

É por decalque do latim que o autor fala em radical do imperfeito para referir-se ao radical do infinitivo - o que fica claro na seguinte passagem, quando deixa claro que trabalha no plano sincrônico:

\footnotetext{
Na conjugação verbal, em português, há certas formas primitivas cujo radical se repete num determinado grupo de outras: - 1) $1^{\text {a }}$ pessoa singular do indicativo presente, cujo radical se repete no subjuntivo presente [...] 2) $2^{\mathrm{a}}$ pessoa singular do indicativo pretérito perfeito, cujo radical se repete no pretérito mais-que-perfeito, subjuntivo pretérito e subjuntivo futuro [...] 3) infinitivo, cujo radical se repete nos futuros do indicativo $[\ldots]$

O conceito de "forma primitiva" é sincrônico, de sorte que a forma primitiva não é a gênese das formas que delas de tiram, necessariamente. (Câmara Jr., 1969: forma primitiva)
}

Aquilo que, em Câmara Jr. (1972), é codificado como $\mathrm{R}_{1}$ não recebe sigla em Câmara Jr. (1972, p. 111), onde o autor fala apenas em "oposição de radical entre 2 IdPr e SbPr", no caso dos verbos valer e saber, dentre outros.

Cumpre notar que 2 IdPr é forma rizotônica escolhida pelo lingüista para, ao lado do infinitivo, caracterizar a conjugação do verbo, quando trata da alternância vocálica, pelo fato de que: 
Se em verbos como lavar, regar, morar o infinitivo nos diz a conjugação, é a segunda pessoa do singular do indicativo presente que nos fornece a vogal exata do radical: /lavas/, /røgas/, /mDras/. Ao contrário, /e/ e /o/ são as verdadeiras vogais radicais, respectivamente, em chegas, espelhas, acenas e tomas. $\mathrm{Na}$ terceira conjugação, a harmonização vocálica da pretônica /e/ ou /o/ à tônica /i/ ainda mais perturba, na língua usual, a identificação da genuína vogal da raiz, que nos é dada, ao contrário, inconfundivelmente em $2 \mathrm{IdPr}$; assim /føris/ em face de ferir, pronunciado /firir/, e /frežis/ em face do infinitivo pronunciado e escrito frigir. (Câmara Jr., 1972, p. 101) ${ }^{9}$

Acontece que, no $\mathrm{SbPr}$, o radical pode não coincidir com o do imperfeito (R), como em valha, valhas, etc., de um lado, e valer, de outro. Aqui, é que entra o $\mathrm{R}_{1}$ - que nada tem a ver com $2 \operatorname{IdPr}$ (vales) - e que, em 1 IdPr de saber, ainda apresenta variação: sei, forma "que sincronicamente pode uma redução do radical sab- e uma alternância /a/-/e/" (Câmara Jr., 1972, p. 111).

Além disso, Câmara Jr. (1972, p. 114-5) trata também do radical supletivo dos verbos ser (em que "um radical básico /E/ alterna com outro /se/") e ir (em que "um radical básico /i/ alterna com outro /va/"').

Finalmente, Câmara Jr. (1970) codifica como R o radical específico dos particípios de "padrão especial", seja para os verbos que têm duplicidade dessa forma nominal (eleger: elegido e eleito), seja para os que têm uma única forma, cujo radical não coincide, porém, com o do infinitivo (fazer: feito).

Luft (1976, p. 54) questiona a existência de um "sufixo flexional" que aglutina, "numa espécie de soma heteróclita, as categorias de modo-tempo e número-pessoa", assim como Pontes (1972, p. 43), que considera a vogal temática

[...] parte do sistema flexional, pois ela acompanha os outros morfemas na flexão, enquanto o tema[,] com seus afixos[,] não faz parte do sistema flexional. Ela pode, inclusive, representar as categorias verbais, como morfema cumulativo, como veremos adiante..$^{10}$

Para Kehdi (1998, p. 226-7), a análise da flexão verbal mattosiana pressupõe a existência de quatro morfemas, tendo a vogal temática função meramente classificatória, mas ressalta que:

[...] se, como os distribucionalistas, não dermos ao morfema $\varnothing$ uma importância excessiva, vamos defrontar-nos com numerosos exemplos de cumulação; as

\footnotetext{
${ }^{9}$ Observe-se que, na terceira conjugação, a harmonização vocálica se dá entre as pretônicas /e/ e /i/, que passam à tônica $/ \mathrm{i} /$, e entre $/ \mathrm{o} / \mathrm{e} / \mathrm{u} /$, que passam à tônica $/ \mathrm{u} /$.

${ }^{10}$ Como, para a autora, o tema é composto pela raiz verbal e eventuais prefixos e sufixos, na frase citada deveria constar ou simplesmente o tema não faz parte do sistema flexional ou a raiz com seus sufixos não fazem parte do sistema flexional.
} 
oposições amo/ama/ame conduzem-nos à depreensão das vogais finais e, no caso de $a m-a$, em cotejo com as outras formas, somos obrigados a reconhecer que a vogal temática também acumula valores modo-temporais e número-pessoais.

A noção de que VT + SF, juntos, expressam valores modo-temporais é o que faz Câmara Jr. (1972, p. 107) chamar, é provável que inadvertidamente, de "irregularidade flexional" o fato de os radicais terminados em $-r$ ou $-z$ não receberem "a vogal temática em 3 IdPr: quer (quer $+e r), f a z(f a z+e r)$, produz (produz $+i r)$, etc.”. Trata-se, antes, de fenômeno regular, explicável pelas formas teóricas *quere, *faze, *produze, como ocorre nos "nomes terminados no singular em consoante pós-vocálica", que "têm uma forma teórica em -e /i/ átono final, que se deduz dos plurais. Comparem-se: feliz - felizes, mar - mares, e assim por diante.” (Câmara Jr., 1970, p. 76).

Por uma questão de ordem prática, serão tomadas como base as siglas de Câmara Jr. (1970), fazendo referência ao radical do infinitivo (identificável em Id e Sb, e também nas formas nominais, da maioria dos verbos) como RI, e ao radical do perfeito (identificável apenas em $\mathrm{IdPt}_{2}, \mathrm{IdPt}_{3}, \mathrm{SbPt}$ e SbFt de alguns verbos) como RP.

\subsection{REgULARIDADE E IRREGULARIDADE VERBAL}

No verbete padrão, Câmara Jr. (1968) não define o termo mas, em variação, mostra que um "padrão" reflete uma "invariabilidade imanente" em face das variantes de cada elemento padronizado da língua (“fonema", "morfema", "semantema" e "padrões frasais").

Não fala, aqui, em padrão verbal, mas o substantivo aparece adjetivado por geral, em Câmara Jr. (1972, 1970), e também regular, em Câmara Jr. (1972). Paralelamente, Câmara Jr. (1970) fala em padrões especiais, que equivalem aos "padrões comuns a pequenos grupos de verbos" (Câmara, 1972).

Vê-se, portanto, que padrão geral é entendido como o da estrutura dos verbos ditos regulares, que serve para as três conjugações, enquanto os padrões especiais são entendidos como os de verbos

[...] ditos irregulares, em que certas partes de algumas "terminações" se afastam do modelo considerado regular e em que (o que ainda é mais relevante) o radical deixa de ser invariável e apresenta mudanças. Aí, as nossas gramáticas apenas enumeram os verbos, que interpretam (nem sempre acertadamente) como irregulares, em ordem alfabética, seriando as formas temporais de cada um.

Com isso passam despercebidas importantes realidades de ordem estrutural, cujo conhecimento tornaria mais compreensíveis as formas irregulares e ipso facto muito 
mais fácil apreendê-las. Acresce que a falta de análise leva a redundâncias de exposição e a considerar irregular muita coisa que está no padrão geral, e, uma vez adquirido este, ficou em princípio sabida. (Câmara Jr., 1972, p. 96)

Contudo, o uso da construção passiva em "verbos ditos irregulares" e "modelo considerado regular", em que o agente pode ser identificado com "as nossas gramáticas", marca a reserva do autor em relação ao conceito de regularidade e irregularidade, ainda que, mais adiante, estabeleça que:

A irregularidade verbal deve, com efeito, ser conceituada como uma variação
morfológica impredizível em face dos padrões gerais, ou regulares, da conjugação.
Assim entendida como um desvio do padrão geral morfológico ela não deixa de ser
regular no sentido de que é suscetível de uma padronização também. (Câmara Jr.,
1972, p. 106)

Ao definir irregularidade, Câmara Jr. (1968) alerta para o fato de que a "depreensão de regras de morfofonêmica põe em evidência paradigmas especiais e reduz muito os verdadeiros casos de irregularidade", dando exemplos dos "paradigmas especiais" (verbos com radical variável por alternância vocálica da segunda conjugação, verbos em -ear e verbos com travamento nasal), mas não dos "verdadeiros casos de irregularidade".

Nenhum desses casos é abordado em Câmara Jr. (1969), que se ocupa apenas dos "verbos regulares" - adjetivo que o parece deixá-lo mais à vontade, quando identifica regularidade flexional com padrão geral, como fica claro no título do capítulo "Flexão verbal portuguesa. O padrão geral”, bem como nos parágrafos introdutórios dos quadros da seção “Estrutura da flexão”, do capítulo sobre o verbo de Câmara Jr. (1975, p. 142-7):

O quadro abaixo dá o padrão geral, ou "regular", da distribuição da vogal do tema nas formas verbais portuguesas $[\ldots]$

Levando em conta a ocorrência de $\varnothing$, temos os quadros seguintes para os sufixos modo-temporais e os sufixos número-pessoais nos verbos portugueses [...]

Consideremos agora o quadro geral dos sufixos número-pessoais ou desinências de pessoa $[\ldots]$

Neste último quadro, todavia, está incorporado um caso de "irregularidade flexional isolada" apontado por Câmara Jr. (1972, 1970): o sufixo -des para a 5 IdPr. Da comparação entre esses textos, constata-se hesitação também na denominação daquilo que constituiria irregularidade de radical.

A título de ilustração, compare-se o tratamento dado aos verbos ter, vir e pôr: considerados como um dos "paradigmas especiais" em Câmara Jr. (1968); um dos "padrões 
especiais dos verbos em português" em Câmara Jr. (1970), mas são tratados sob a identificação de "radicais com travamento nasal [...] que apresentam uma variação mais complexa" que a dos verbos nos quais "a oposição de radical entre 2 IdPr e SbPr se apresenta de maneira errática e impredizível” (Câmara Jr., 1972, p. 111-2).

O mesmo está declarado em Câmara Jr. (1975, p. 154-5):

\begin{abstract}
Num número limitado de verbos, ao contrário [das alternâncias vocálicas], a oposição entre radical básico, da $2^{\mathrm{a}}$ pessoa singular do indicativo presente, e radical do presente do subjuntivo (que nem sempre abrange a $1^{\text {a }}$ pessoa singular do indicativo presente), se faz de maneira impredizível e irregular. O único recurso descritivo é aí a enumeração, em lista, dos verbos que apresentam essa posição.

[...] A esta lista deve-se acrescentar três radicais de travamento nasal, em que a troca [da consoante final do radical] é entre o travamento nasal e uma consoante nasal palatal $[\ldots]$
\end{abstract}

Como se vê, as alternâncias vocálicas não são consideradas fenômeno irregular: páginas antes, o autor declara que, “dentro de um princípio geral de 'regularidade', há as alternâncias vocálicas", que se distinguem de outros verbos em que a variação se dá "de maneira impredizível e irregular”. (Câmara Jr., 1975, p. 148-59). Além disso, já se viu que, em Câmara Jr. (1968), são vistas como "paradigma especial” e, em Câmara Jr. (1970), são tratadas no capítulo sobre o "padrão geral” da flexão verbal portuguesa.

No entanto, examinando-se a seqüência de subtítulos em Câmara Jr. (1972, p. 106-13), isso parece mudar de figura:

\footnotetext{
Conceito da irregularidade verbal

As irregularidades de radical; radicais do perfeito

As alternâncias vocálicas no presente

Outras variações de radical no presente

Radicais com travamento nasal

Radicais do imperfeito supletivos
}

Estando entre as "irregularidades" de radical do perfeito e outras "variações" de radical no presente, é-se levado a pensar que as "alternâncias vocálicas no presente" constituem irregularidade. É possível que uma declaração a esse respeito tenha feito parte dos originais do autor, pois no primeiro parágrafo do seguinte trecho há um evidente salto no texto, provavelmente de uma ou mais linhas: 
O radical do imperfeito, mesmo no padrão geral de se estender ao verbo todo, pode por sua vez apresentar variações.

Não se pode desconsiderar, entretanto, o que diz no parágrafo seguinte: que, nas segunda e terceira conjugações, a alternância "se verifica rigorosamente e sistematicamente em condições determinadas" - como se predizíveis, portanto.

Ressalte-se o que diz Kehdi (1998, p. 134): “a alternância verbal configura irregularidade, pois não é predizível (cp. acudo/acodes e iludo/iludes)", atribuindo o tratamento desses verbos como regulares a um "problema de revisão" em Câmara Jr. (1970).

Com relação aos particípios, a hesitação permanece: Câmara Jr. (1970, p. 105) fala em “padrão especial [...] em variação livre com o padrão geral”, que equivalem, respectivamente, ao particípio irregular e regular, em Câmara Jr. (1975, p. 160):

Podemos assim levar em conta dois tipos de formas de particípio perfeito em
português: 1) a "regular", com sufixo -do, acompanhado da vogal do tema em - $a$ ou
em - $-i$ (salvo em vindo); 2) uma irregular, impredizível, sem sufixo, constituída de
um radical verbal e a vogal do tema nominal, e que é, evidentemente, rizotônica ou
"forte".

A irregularidade estaria, então, nos fenômenos não predizíveis pelas regras fonológicas, todas relacionadas com a flexão, em condições determinadas: a crase e a supressão de certos segmentos vocálicos; a mudança de timbre, a ditongação e a redução de vogais a semivogais. Dessa forma, seriam irregulares os verbos com variações do radical, mas que Câmara Jr. $(1970,1972)$ considera como "um desvio do padrão geral morfológico, que não deixa de ser regular", pois passível de padronização.

Aí, irregularidade e regularidade acabam por confundir-se até porque Câmara Jr. (1972) faz entrever uma ambigüidade na conceituação do primeiro desses termos como uma "variação morfológica impredizível em face dos padrões gerais", ou ainda, um "desvio do padrão geral morfológico". Ou seja: há um único padrão geral, que se deve considerar regular ao lado de outros padrões irregulares, ou vários "padrões gerais" com regularidade interna, que corresponderiam aos padrões especiais?

Esta última hipótese não parece absurda, diante da afirmação de que:

Os padrões especiais [...] não são inteiramente caprichosos e arbitrários. Há neles uma organização imanente, que se impõe claramente depreender. Como na loucura, há uma lógica implícita, que o gramático, como naquela o psiquiatra, tem o dever de explicitar. (Câmara Jr., p. 101) 
A idéia já se encontra em Marouzeau (1943, verbete irrégulier), quando conceitua verbos irregulares:

\begin{abstract}
Chamam-se comumente irregulares as formas ou construções que não estão inteiramente de acordo com um tipo considerado como normal: fr. je veux [quero] é dito irregular em relação a nous voulons [queremos], [...], quando se comparam je foule, nous foulons [prenso, prensar]. É nesse sentido que se fala de declinações e conjugações irregulares, de verbos irregulares, etc. Como a irregularidade aparente resulta, em geral, da aplicação de regras não percebidas, o termo é no mais das vezes empregado de forma imprópria, e tende-se hoje em dia a substituí-lo por anômalo. ${ }^{11}$
\end{abstract}

No verbete anomalie, o autor reconhece "o caráter aberrante de uma forma ou construção, dita anômala [...] em relação a um tipo, um sistema, uma regra que rege uma categoria", dando exemplos de verbos da terceira conjugação dos verbos em francês, que diferentemente do que ocorre em qualquer das três conjugações do verbo português - se multiplica em "tipos" verbais. ${ }^{12}$.

Desconsiderando, aqui, a questão da irregularidade (e, portanto, da irregularidade) a oposição será feita entre padrão geral e padrões especiais, levando-se em conta que:

\title{
1.3 Padrão geral
}

Aqui será vista a estrutura da forma verbal portuguesa, considerando-se a forma invariável do radical do infinitivo. Inicialmente, será descrita a alomorfia da vogal temática; em seguida a do sufixo modo-temporal e, finalmente, a do sufixo número-pessoal.

\footnotetext{
${ }^{11}$ No original, "On appelle communnément irrégulières les formes ou constructions qui ne sont pas entièrement conformes à un type consideré comme normal: fr. je veux, est dit irrégulier par rapport à nous voulons quand on compare: je foule, nous foulons. C'est en ce sens qu'on parle de déclinaisons et conjugaisons irrégulières, de verbes irréguliers, etc. Comme l'irrégularité apparente résulte en générale de l'application de règles non aperçues, le terme est employé le plus souvent d'une manière impropre, et on tend aujourd'hui à lui substituer le terme d'anomal."

${ }^{12} 1^{\circ}$ ) No original, "Le terme est employé aujourd'hui pour exprimer le caractère aberrant d'une forme ou d'une construction dite anomale [anomal, unregelemässig; anomalous] par rapport 'a un type, à un système, à une règle qui régit une categorie: pris de prendre, est anomal par rapport a rendu, tendu, vendu, de rendre, tendre, vendre." $2^{\circ}$ ) Para a terceira conjugação, Le nouveau Bescherelle (1966) propõe 61 tábuas de conjugação-modelo. Só de verbos em -re - todos vindos da segunda e da terceira conjugações latinas -, há 24 tábuas verbos-modelo. Dentre elas, contam-se oito de verbos em -dre: dos "verbes en -dre: rendre / verbes en -andre, -endre, -ondre, -erdre, -ordre" (particípio em -du), do "verbe prendre" (particípio em -is), dos "verbes en -eindre: peindre" (particípio em -eint), dos "verbes en -oindre: joindre" (particípio em -oint), dos "verbes en -aindre: craindre" (particípio em -aint), dos "verbes en -oudre: absoudre" (particípio em -ous/oute), dos verbos em coudre (particípio em -su); dos verbos em moudre (particípio em -lu).
} 


\subsubsection{Alomorfia Para a VT}

Cada uma das conjugações é caracterizada por uma vogal tônica no infinitivo: /a/, na primeira; /e/, na segunda e /i/, na terceira. Entretanto, em alguns casos, as vogais características aparecem fora da sílaba tônica - seja na pretônica $\left(\mathrm{IdFt}_{1}\right.$ e $\left.\mathrm{IdFt}_{2}\right)$, seja em sílaba átona final (2,3,6 IdPr). Aqui, o /a/ passa a /[/, na primeira conjugação, e a oposição entre /e/ e /i/ (representados graficamente por um $e$ ) se neutraliza, nas duas outras conjugações. ${ }^{13}$

Além disso, na primeira conjugação, "a vogal temática /a/ não é integralmente estável” - o que explica dois alomorfes em sílaba tônica: /e/ (1 $\left.\mathrm{IdPt}_{2}\right)$ e /o/ (3 $\left.\mathrm{IdPt}_{2}\right)$. Essas formas mantêm paralelismo com as correspondentes da segunda e terceira conjugação, como mostra Câmara Jr. (1972, p. 102), por meio de uma regra fonológica: de um lado, em parti e temi, "a vogal temática é $i$ tônico e com ela se fundiu SNP /y/, que se encontra em /ka(n) tey.'”; de outro, cantou apresenta a mesma estrutura das duas correspondentes: “( canto $+o)(\varnothing+u)$ como $($ tem $+e)(\varnothing+u),($ part $+i)(\varnothing+u) "$.

Vê, se, portanto, que também não é estável a vogal temática na segunda conjugação, passando de /e/ para /i/ não só em $1 \mathrm{IdPt}_{2}$, mas também em $\mathrm{IdPt}_{1}$ e Pa, que se comportam como os verbos da terceira conjugação. No caso de $\operatorname{IdPt}_{1}$ e $1 \mathrm{IdPt}_{2}$, "há respectivamente a crase com SNP -ia, átono, e 1SNP /y/: temia, partia $=($ tem, part $+i)+i a ;$ temi, parti $=($ tem, part $+\mathrm{i})+i(/ \mathrm{y} /)^{\prime}$ (Câmara Jr., 1966, p. 102-3).

Com base em outra regra fonológica, segundo a qual a "vogal final átona de um elemento mórfico é suprimida, na estruturação do vocábulo, quando se adjunge outro elemento mórfico de inicial diversa", Câmara Jr. (1972, p. 103) explica a "ausência da vogal temática" em contato com o SF que começa por vogal: estando ela em sílaba átona (em $1 \mathrm{IdPr}$ e 1,2,3,6 SbPr), como em "canta $+o=$ canto; canta $+e=$ cante", ou pretônica (em 4,5 SbPr), como em "canta $+e$ (tônico) + mos = cantemos".

Em Câmara Jr. (1975, p. 142), essa supressão figura como morfema Ø no "quadro da distribuição da vogal do tema nas formas verbais portuguesas":

$$
\begin{aligned}
& \text { Indicativo presente }-1^{\mathrm{a}} \text { pessoa singular: } \operatorname{am}(\varnothing) o, \operatorname{tem}(\varnothing) o, \operatorname{part}(\varnothing) o \\
& \text { Subjuntivo presente: } \operatorname{am}(\varnothing) e, \text { etc.; } \operatorname{tem}(\varnothing) a, \text { etc.; } \operatorname{part}(\varnothing) a, \text { etc. }
\end{aligned}
$$

\footnotetext{
${ }^{13}$ Nos dois futuros do indicativo - resultantes da aglutinação de duas formas verbais -, a mesóclise denuncia o caráter artificial da vogal temática em posição pretônica: separado das formas reduzidas do verbo haver flexionado, a vogal temática reassume, no infinitivo, sua tonicidade.
} 
Baseado na aplicação das mesmas regras morfofonêmicas postuladas pelo lingüista, Kehdi (1998, p. 110) chama atenção para o fato de que:

Relativamente ao morfema $\varnothing$, ressalte-se que um dos traços que o caracteriza é o fato de ele não poder ser recuperado; o singular caracteriza-se pelo morfema $\varnothing$, em oposição ao plural (marcado pelo morfema /z/), justamente porque não existe, em português, desinência de singular. Ora, a VT pode ser sempre recuperada; sua ausência numa determinada forma verbal decorre da aplicação de leis fonológicas explícitas e gerais.

Em, seus "paradigmas de conjugação verbal", Luft (2000, p. 134-5) parece assumir essa mesma posição, quando usa parênteses para assinalar a VT apagada, e não zero, como se pode ver na reprodução parcial do seu quadro, no Quadro 1.2.

\section{Quadro 1.2 - Reprodução de PaRTe do QuAdro dos Paradigmas de CONJUgaÇão REgular de LuFT (2000)}

\begin{tabular}{|c|c|c|c|c|c|c|c|c|c|c|c|}
\hline \multicolumn{12}{|c|}{ INDICATIVO } \\
\hline \multicolumn{4}{|c|}{$1^{\mathrm{a}} \mathrm{CONJ}$} & \multicolumn{4}{|c|}{$2^{\mathrm{a}} \mathrm{CONJ}$} & \multicolumn{4}{|c|}{$3^{\mathrm{a}} \mathrm{CONJ}$} \\
\hline \multicolumn{2}{|c|}{$\mathrm{T}$} & \multicolumn{2}{|c|}{ D } & \multicolumn{2}{|c|}{$\mathrm{T}$} & \multicolumn{2}{|c|}{$\mathrm{D}$} & \multicolumn{2}{|c|}{$\mathrm{T}$} & \multicolumn{2}{|c|}{ D } \\
\hline $\mathrm{R}$ & VT & MT & NP & $\mathrm{R}$ & VT & MT & NP & $\mathrm{R}$ & VT & MT & NP \\
\hline compr & (a) & $\varnothing$ & 0 & vend & (e) & $\varnothing$ & 0 & part & (i) & $\varnothing$ & 0 \\
\hline compr & $\mathrm{a}$ & $\varnothing$ & $\mathrm{S}$ & vend & $\mathrm{e}$ & $\varnothing$ & $\mathrm{S}$ & part & $\mathrm{i} \rightarrow \mathrm{e}$ & $\varnothing$ & $S$ \\
\hline compr & $a$ & $\varnothing$ & $\varnothing$ & vend & $\mathrm{e}$ & $\varnothing$ & $\varnothing$ & part & $\mathrm{i} \rightarrow \mathrm{e}$ & $\varnothing$ & $\varnothing$ \\
\hline compr & $\mathrm{a}$ & $\varnothing$ & mos & vend & $\mathrm{e}$ & $\varnothing$ & mos & part & $\mathrm{i}$ & $\varnothing$ & mos \\
\hline compr & $\mathrm{a}$ & $\varnothing$ & is & vend & $\mathrm{e}$ & $\varnothing$ & is & part & (i) & $\varnothing$ & is \\
\hline compr & $\mathrm{a}$ & $\varnothing$ & $\mathrm{m}$ & vend & $\mathrm{e}$ & $\varnothing$ & $\mathrm{m}$ & part & $\mathrm{i} \rightarrow \mathrm{e}$ & $\varnothing$ & $\mathrm{m}$ \\
\hline
\end{tabular}

Quando, na terceira conjugação, há neutralização entre as duas vogais, codifica a oposição entre /e/ e /i/ (representados graficamente por um $e$ ) por $i \rightarrow e$, sem dar destaque à representação gráfica $e$.

Numa tentativa de tornar graficamente visualizável a alomorfia da VT nos modos e tempos, e nas formas nominais das três conjugações, elaborou-se o Quadro 1.3, considerandose que, em determinadas condições, o morfema é apagado, e não propriamente zero. 


\section{Quadro 1.3 - Alomorfes para a VT}

\begin{tabular}{|c|c|c|c|c|c|c|c|c|c|c|c|c|c|c|c|c|c|c|}
\hline & \multicolumn{6}{|c|}{$1^{\mathrm{a}}$ conjugação } & \multicolumn{6}{|c|}{$2^{\mathrm{a}}$ conjugação } & \multicolumn{6}{|c|}{$3^{\mathrm{a}}$ conjugação } \\
\hline & 1 & 2 & 3 & 4 & 5 & 6 & 1 & 2 & 3 & 4 & 5 & 6 & 1 & 2 & 3 & 4 & 5 & 6 \\
\hline $\operatorname{IdPr}$ & $(/ \mathrm{a} /)$ & $/ \mathrm{a} /$ & $/ \mathrm{a} /$ & /'a/ & /'a/ & $/ \mathrm{a} /$ & $(/ \mathrm{e} /-/ \mathrm{i} /)$ & $/ \mathrm{e} /-\mathrm{i} /$ & /e/-/i/ & /'e/ & /'e/ & /e/ & $\begin{array}{c}(/ \mathrm{e} /- \\
/ \mathrm{i} / \mathrm{)}\end{array}$ & $(/ \mathrm{e} /-/ \mathrm{i} /)$ & $(/ \mathrm{e} /-\mathrm{i} /)$ & /'i/ & /'i/ & /e/ \\
\hline $\mathrm{IdPt}_{1}$ & /'a/ & /'a/ & $/ ' \mathrm{a} /$ & $/ ' \mathrm{a} /$ & /'a/ & /'a/ & $(/ \mathrm{e} /)$ & $(/ \mathrm{e} /)$ & $(/ \mathrm{e} /)$ & $(/ \mathrm{e} /)$ & $(/ \mathrm{e} /)$ & $(/ \mathrm{e} /)$ & $(/ \mathrm{i} /)$ & $(/ \mathrm{i} /)$ & $(/ \mathrm{i} /)$ & $(/ \mathrm{i} /)$ & $(/ \mathrm{i} /)$ & $(/ \mathrm{i} /)$ \\
\hline $\mathrm{IdPt}_{2}$ & /'e/ & /'a/ & /'o/ & /'a/ & /'a/ & /'a/ & $(/ \mathrm{e} /)$ & /'e/ & /'e/ & /'e/ & /'e/ & /'e/ & $(/ \mathrm{i} /)$ & /'i// & /'i/ & $/ / \mathrm{i} /$ & /'i// & /'i/ \\
\hline $\mathrm{IdPt}_{3}$ & /'a/ & /'a/ & /'a/ & /'a/ & /'a/ & /'a/ & /'e/ & /'e/ & /'e/ & /'e/ & /'e/ & /'e/ & /'i/ & /'i/ & $/ / \mathrm{i} /$ & $/ / \mathrm{i} /$ & & $/ / \mathrm{i} /$ \\
\hline $\mathrm{IdFt}_{1}$ & /a/ & /a/ & /a/ & /a/ & /a/ & $/ \mathrm{a} /$ & /e/ & /e/ & /e/ & /e/ & /e/ & /e/ & $/ \mathrm{i} /$ & $/ \mathrm{i} /$ & $/ \mathrm{i} /$ & $/ \mathrm{i} /$ & /i/ & $/ \mathrm{i} /$ \\
\hline $\mathrm{IdFt}_{2}$ & $/ \mathrm{a} /$ & /a/ & $/ \mathrm{a} /$ & /a/ & /a/ & /a/ & /e/ & /e/ & le/ & le/ & /e/ & /e/ & $/ \mathrm{i} /$ & $/ \mathrm{i} /$ & $/ \mathrm{i} /$ & $/ \mathrm{i} /$ & $/ \mathrm{i} /$ & /i/ \\
\hline $\mathrm{SbPr}$ & $(/ \mathrm{a} /)$ & $(/ \mathrm{a} /)$ & $(/ \mathrm{a} /)$ & $(/ \mathrm{a} /)$ & $(/ \mathrm{a} /)$ & $(/ \mathrm{a} /)$ & $(/ \mathrm{e} /)$ & $(/ \mathrm{e} /)$ & $(/ \mathrm{e} /)$ & $(/ \mathrm{e} /)$ & $(/ \mathrm{e} /)$ & $(/ \mathrm{e} /)$ & $(/ \mathrm{i} /)$ & $(/ \mathrm{i} /)$ & $(/ \mathrm{i} /)$ & $(/ \mathrm{i} /)$ & $(/ \mathrm{i} /)$ & $(/ \mathrm{i} /)$ \\
\hline $\mathrm{SbPt}$ & /'a/ & /'a/ & $/ \mathrm{a} /$ & $/ ' \mathrm{a} /$ & /'a/ & $/$ 'a/ & /'e/ & /'e/ & /'e/ & $/ / \mathrm{e} /$ & $/$ e/ & /'e/ & /'i/ & /'i/ & $/$ i/ & $/ / \mathrm{i} /$ & $/ / \mathrm{i} /$ & /'i/ \\
\hline $\mathrm{SbFt}$ & /'a/ & $/$ 'a/ & /'a/ & $/$ 'a/ & $/$ 'a/ & $/ ' \mathrm{a} /$ & /'e/ & /'e/ & /'e/ & /'e/ & /'e/ & /'e/ & /'i/ & /'i/ & /'i/ & /'i/ & /'i/ & $/ / \mathrm{i} /$ \\
\hline If & $/ \mathrm{a} /$ & /'a/ & $/$ 'a/ & /'a/ & $/ ' \mathrm{a} /$ & $/ ' \mathrm{a} /$ & /'e/ & /'e/ & $/$ 'e/ & /'e/ & /'e/ & /'e/ & /'i/ & /'i/ & /'i/ & $/ \mathrm{i} /$ & /'i/ & $/ / \mathrm{i} /$ \\
\hline $\mathrm{Gr}$ & \multicolumn{6}{|c|}{ /'a/ } & \multicolumn{6}{|c|}{ /'e/ } & \multicolumn{6}{|c|}{ /'i// } \\
\hline $\mathrm{Pa}$ & \multicolumn{6}{|c|}{ /'a/ } & \multicolumn{6}{|c|}{ /'i/ } & \multicolumn{6}{|c|}{ /'i/ } \\
\hline
\end{tabular}

Observações:

$1^{\text {a }) ~ E m ~(/ e /-/ i /), ~ e s t a ́ ~ r e p r e s e n t a d a ~ a ~ n e u t r a l i z a c ̧ a ̃ o ~ e n t r e ~ o s ~ f o n e m a s, ~ q u e ~ s a ̃ o ~ r e p r e s e n t a d o s ~ g r a f i c a m e n t e ~ p o r ~} e$

$2^{\mathrm{a}}$ ) Em /'a/, /'e/ e /'i/, a VT é tônica. Em /a/, /e/ e /i/, é átona pós-tônica (em $3 \mathrm{IdPr}$ canta, vende, p.ex.) ou pretônica (em 1 IdFt ${ }_{2}$ cantaria, venderia, partiria, p.ex.). 
Conforme se pode ver no Quadro 1.3, na primeira conjugação a VT só não é /a/ (tônico ou átono) em nove formas (com supressão em sete; /o/ em uma, e /e/ em outra) e, na segunda e terceira conjugações, só não é /e/-/i/ (neutralizados em sílaba átona) em sete formas (com supressão em todas).

Note-se ainda que, em contato com outra vogal do radical, /e/-/i/, neutralizadas, passam à semivogal [j], grafada $i$ (róis, atrais, instruis, p.ex.). O mesmo ocorre com põe, pões - o que é uma comprovação, no plano sincrônico, de que o verbo faz parte da segunda conjugação, como mostra Câmara Jr. (1972, p. 113):

Partindo do infinitivo, algumas gramáticas classificam ter na segunda conjugação e vir na terceira e alguns chegam a considerar em pôr uma quarta conjugação com a vogal temática -o- apesar de põe, pões, que mostram um radical põ/po(n) e uma vogal temática /e/ com ele ditongada de acordo com a regra fonológica 5. [...]

Portanto, é mais do que pertinente a constatação de Câmara Jr. (1972, p. 101) de que:

[...] A verdadeira oposição é entre a primeira conjugação e uma outra subdividida em duas subconjugações. Não só fonologicamente, pela neutralização da oposição /e/-/i/ nas formas rizotônicas (temes, partes), a segunda e a terceira conjugações se confundem. [...]. Em IdPt $\mathrm{I}_{1}$, há uma vogal temática /i/, tônica, na "terminação" -ia, comum às duas terminações [...], e em $1 \mathrm{IdPt}_{2}$ há igualmente essa vogal temática $[\ldots]$.

\subsubsection{Alomorfia para o SMT}

Sem considerar as formas em que a VT se funde com o SNP ou é suprimida, nos outros modos e tempos ( $\mathrm{IdPt}_{3}, \mathrm{IdFt}_{1}, \mathrm{IdPt}_{2}, \mathrm{SbPt}$; SbFt; If; além de $\mathrm{IdPt}_{1}$ na primeira conjugação) o SMT segue-se à vogal temática.

Câmara Jr. (1975) apresenta um quadro para o sufixo modo-temporal nos verbos portugueses, destacando, à esquerda, os morfemas e indicando, à direita, os modos e tempos em que eles ocorrem. ${ }^{14}$

$\mathrm{Na}$ tentativa de tornar graficamente visualizável a alomorfia da VT, elaborou-se o Quadro 1.4, onde se destacam os alomorfes que diferem do predominante em cada modo e tempo.

\footnotetext{
${ }^{14} \mathrm{O}$ quadro "para o sufixo modo-temporal nos verbos portugueses" está reproduzido no Anexo 1.
} 


\section{Quadro 1.4 - Alomorfes para o SMT nas formas flexionadas}

\begin{tabular}{|c|c|c|c|c|c|c|c|}
\hline \multicolumn{2}{|c|}{$\begin{array}{l}\text { pessoas } \\
\text { modos e tempos }\end{array}$} & 1 & 2 & 3 & 4 & 5 & 6 \\
\hline \multirow{2}{*}{$\mathrm{IdPt}_{1}$} & $1^{\mathrm{a}}$ conjugação & $/ \mathrm{va} /$ & $/ \mathrm{va} /$ & $/ \mathrm{va} /$ & $/ \mathrm{va} /$ & $/ \mathrm{ve} /$ & $/ \mathrm{va} /$ \\
\hline & $2^{\mathrm{a}}$ e $3^{\mathrm{a}}$ conjugações & /'i.a/ & /'i.a/ & /'i.a/ & /'i.a/ & /'i.e/ & /'i.a/ \\
\hline \multirow{2}{*}{$\mathrm{SbPr}$} & $1^{\mathrm{a}}$ conjugação & /e/ & /e/ & /e/ & /e/ & $/ \mathrm{e} /$ & le/ \\
\hline & $2^{\mathrm{a}}$ e $3^{\mathrm{a}}$ conjugações & $/ \mathrm{a} /$ & $/ \mathrm{a} /$ & $/ \mathrm{a} /$ & $/ \mathrm{a} /$ & $/ \mathrm{a} /$ & $/ \mathrm{a} /$ \\
\hline $\operatorname{IdPr}$ & \multirow{10}{*}{$\begin{array}{l}1^{\mathrm{a}}, 2^{\mathrm{a}} \text { e } 3^{\mathrm{a}} \\
\text { conjugações }\end{array}$} & $\varnothing$ & $\varnothing$ & $\varnothing$ & $\varnothing$ & $\varnothing$ & $\varnothing$ \\
\hline $\mathrm{SbPt}$ & & $/ \mathrm{se} /$ & $/ \mathrm{se} /$ & $/ \mathrm{se} /$ & $/ \mathrm{se} /$ & $/ \mathrm{se} /$ & $/ \mathrm{se} /$ \\
\hline $\mathrm{IdPt}_{3}$ & & $/ \bar{a} /$ & $/ \overline{\mathrm{a} /}$ & $/ \mathrm{Da} /$ & $/ \mathrm{Da} /$ & $/ \mathrm{De} /$ & $/ \mathrm{aa} /$ \\
\hline $\mathrm{IdFt}_{1}$ & & $/ / \mathrm{aa} /$ & $/[\bar{a} /$ & $/ / \bar{a} /$ & $/ \mathrm{Ia} /$ & /'Пe/ & $/ " \square \mathrm{a} /$ \\
\hline $\mathrm{IdFt}_{2}$ & & $/$ "'十i.a/ & /"पi.a/ & /'"'i.a/ & /"'Ti.a/ & /'Di.e/ & /"'Ti.a/ \\
\hline $\mathrm{IdPt}_{2}$ & & $\varnothing$ & $\varnothing$ & $\varnothing$ & $\varnothing$ & $\varnothing$ & /Da/ \\
\hline $\mathrm{SbFt}$ & & $/[/$ & $/ \overline{\mathrm{e}} /$ & $/ / /$ & /[// & $/[/$ & $/ \mathrm{De} /$ \\
\hline If & & $/$ /[/ & $/[\mathrm{e} /$ & 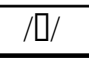 & /[// & $/[/$ & $/ \mathrm{De} /$ \\
\hline $\mathrm{Gd}$ & & \multicolumn{6}{|c|}{$/ \mathrm{Ndo} /$} \\
\hline $\mathrm{Pa}$ & & \multicolumn{6}{|c|}{$/ \mathrm{do} /$} \\
\hline
\end{tabular}

O cotejo desses alomorfes torna ainda mais flagrante a divisão entre a primeira conjugação e as outras duas, diante da existência de um sufixo modo-temporal privativo da primeira conjugação em $\mathrm{IdPt}_{1}$ e PrSb. Nos demais tempos e nas formas nominais, as três conjugações têm exatamente os mesmos SMTs.

É curioso que, em seis tempos, o SMT apresenta uma forma variante para determinadas pessoas, ou seja, o SMT reforça o SNP:

- para $5 \mathrm{IdPt}_{3}, 5 \mathrm{IdFt}_{1}$ e $5 \mathrm{IdFt}_{2}$, uma forma em -e (/[e/, /'Пe/ e /'̃̃ie/) opõe-se a uma forma em $-a(/ \mathrm{Da} /, / / \mathrm{a} \mathrm{a} / \mathrm{e} / / \mathrm{C} . \mathrm{ia} /)$ para as outras cinco pessoas;

- para $6 \mathrm{IdPt}_{2}$, coincidindo com $6 \mathrm{IdPt}_{3}, / / \mathrm{aa} /$ opõe-se a $\varnothing$ para as outras cinco pessoas, e

- $\quad$ para 3,6 SbFt e If, uma forma /[e/ opõe-se a /[/ para as outras quatro pessoas.

\subsubsection{Alomorfia Para o SNP}

Também para o sufixo número-pessoal de $6 \mathrm{IdPr}, \mathrm{SbPr}_{1}$ e $\operatorname{SbPr}_{2}$ está refletida a divisão entre a primeira e as outras duas conjugações, facilmente percebida no Quadro 1.5, onde se pretendeu deixar graficamente mais claras as informações do quadro para os sufixos númerospessoais de Câmara Jr. (1975). ${ }^{15}$

\footnotetext{
${ }^{15} \mathrm{O}$ quadro "para o sufixo número-pessoal nos verbos portugueses” está reproduzido no Anexo 2.
} 


\section{Quadro 1.5 - Alomorfes Para o SNP}

\begin{tabular}{|c|c|c|c|c|c|c|c|}
\hline \multicolumn{2}{|c|}{$\begin{array}{ll} & \text { pessoas } \\
\text { modos e tempos } & \end{array}$} & 1 & 2 & 3 & 4 & 5 & 6 \\
\hline \multirow{2}{*}{$\mathrm{IdPr}$} & $1^{\mathrm{a}}$ conjugação & \multirow{2}{*}{ /o/ } & \multirow{2}{*}{$/ \mathrm{s} /$} & \multirow{2}{*}{$\varnothing$} & \multirow{2}{*}{$/ \mathrm{mos} /$} & \multirow{2}{*}{ /is/ } & $/ \mathrm{u}_{\mathrm{N}} /$ \\
\hline & $2^{\mathrm{a}} \mathrm{e} 3^{\mathrm{a}}$ conjugações & & & & & & $\mathrm{u}_{\mathrm{N} /}$ \\
\hline \multirow{2}{*}{$\mathrm{SbPr}_{2}$} & $1^{a}$ conjugação & \multirow{2}{*}{$\varnothing$} & \multirow{2}{*}{$/ \mathrm{s} /$} & \multirow{2}{*}{$\varnothing$} & \multirow{2}{*}{$/ \mathrm{mos} /$} & \multirow{2}{*}{ /is/ } & $\mathrm{u}_{\mathrm{N} /}$ \\
\hline & $2^{\mathrm{a}} \mathrm{e} 3^{\mathrm{a}}$ conjugações & & & & & & $/ \mathrm{N} /$ \\
\hline \multirow{2}{*}{$\mathrm{SbPr}_{1}$} & $1^{a}$ conjugação & & \multirow{2}{*}{$\varnothing$} & \multirow{2}{*}{$\varnothing$} & \multirow{2}{*}{$/ \mathrm{mos} /$} & \multirow{2}{*}{ /i/ } & $\mathrm{u}_{\mathrm{N}} /$ \\
\hline & $2^{\mathrm{a}}$ e $3^{\mathrm{a}}$ conjugações & & & & & & $/ \mathrm{N} /$ \\
\hline \multirow{2}{*}{$\mathrm{IdPt}_{2}$} & $1^{a}$ conjugação & $/ \mathrm{j} /$ & \multirow{2}{*}{ /ste/ } & \multirow{2}{*}{$/ \mathrm{w} /$} & \multirow{2}{*}{$/ \mathrm{mos} /$} & \multirow{2}{*}{ /stes/ } & \multirow{2}{*}{$/ \mathrm{u}_{\mathrm{N}} /$} \\
\hline & $2^{\mathrm{a}}$ e $3^{\mathrm{a}}$ conjugações & $/ \mathrm{i} /$ & & & & & \\
\hline $\mathrm{IdPt}_{1}$ & \multirow{7}{*}{$\begin{array}{c}1^{\mathrm{a}}, 2^{\mathrm{a}} \text { e } 3^{\mathrm{a}} \\
\text { conjugações }\end{array}$} & $\varnothing$ & $/ \mathrm{s} /$ & $\varnothing$ & $/ \mathrm{mos} /$ & /is/ & $/ \mathrm{u}_{\mathrm{N}} /$ \\
\hline $\mathrm{IdPt}_{3}$ & & $\varnothing$ & $/ \mathrm{s} /$ & $\varnothing$ & $/ \mathrm{mos} /$ & /is/ & $\mathrm{u}_{\mathrm{N}} /$ \\
\hline $\mathrm{IdFt}_{1}$ & & $\varnothing$ & $/ \mathrm{s} /$ & $\varnothing$ & $/ \mathrm{mos} /$ & /is/ & $/ \mathrm{u}_{\mathrm{N}} /$ \\
\hline $\mathrm{IdFt}_{2}$ & & $\varnothing$ & $/ \mathrm{s} /$ & $\varnothing$ & $/ \mathrm{mos} /$ & /is/ & $\mathrm{u}_{\mathrm{N} /}$ \\
\hline $\mathrm{SbPt}$ & & $\varnothing$ & $/ \mathrm{s} /$ & $\varnothing$ & $/ \mathrm{mos} /$ & /is/ & $/ \mathrm{N} /$ \\
\hline $\mathrm{SbFt}$ & & $\varnothing$ & $/ \mathrm{s} /$ & $\varnothing$ & $/ \mathrm{mos} /$ & /is/ & $/ \mathrm{N} /$ \\
\hline If & & $\varnothing$ & $/ \mathrm{s} /$ & $\varnothing$ & $/ \mathrm{mos} /$ & /is/ & $/ \mathrm{N} /$ \\
\hline
\end{tabular}

OBSERVAÇÕEs:

$1^{\text {a) }} \mathrm{O}$ imperativo afirmativo $\left(\operatorname{SbPr}_{1}\right)$ - por oposição ao presente do subjuntivo $\left(\operatorname{SbPr}_{2}\right)$ - está incluído aqui pelo fato de apresentar alomorfes privativos de SNP.

$2^{\mathrm{a}}$ ) Tomou-se $/{ }^{\mathrm{u}} \mathrm{N} /$ a Câmara Jr. (1970, p. 99) para representar a nasalização da vogal temática, grafada $-m$.

Em quatro tempos, a primeira conjugação distingue-se das outras duas. No presente do indicativo e do subjuntivo, bem como no imperativo, o alomorfe é $/ \mathrm{u}_{\mathrm{N}} /$ na primeira conjugação (cantam, p.ex.) - ou seja, além de nasalizar-se, o /a/ do SMT ditonga-se em [ãw] - e /N/, na segunda e terceira (vendem e partem, p.ex.). No pretérito perfeito do indicativo, é /j/ em ditongo com a VT /e/ na primeira conjugação (cantei, p.ex.) e em crase com a mesma VT, na segunda e na terceira (vendi e parti, p.ex.).

\subsection{Padrões especiais}

Reproduzindo-se as informações de Câmara Jr. (1970, 1972, 1970), neste estudo os grupos de verbos serão organizados de forma ligeiramente diferente. Em primeiro lugar, virão os aqui fixados padrão especial para o grupo do presente e padrão especial para o grupo do perfeito. Finalmente, serão examinados os padrões especiais para o particípio.

É preciso advertir que, com exceção do unipessoal prazer (que não apresenta padrão especial para o grupo do presente, já que lhe falta $1 \mathrm{IdPr}$ e $\mathrm{SbPr}$ ), todos os verbos que se 
encaixam no padrão especial para o grupo do perfeito encaixam-se também no dos padrões especiais para o grupo do presente e para os dois futuros do indicativo. Alguns poucos verbos que apresentam padrões especiais para o particípio também apresentam padrões especiais nas formas flexionadas.

Finalmente, há um caso isolado de variação no $\mathrm{RI}$ em $\mathrm{IdFt}_{1}$ e $\mathrm{IdFt}_{2}$ : trata-se dos "três verbos de consoante final /z/ da segunda conjugação". Em fazer, trazer e dizer, o radical perde sua sílaba final, -ze, mantendo-se apenas o SMT e SNP.

\subsubsection{Padrões EsPeciais Para o grupo do PRESENTE}

Há três subpadrões para o grupo do presente:

- o dos verbos da primeira conjugação com alternância vocálica;

- o dos verbos das segunda e terceira conjugações com alternância vocálica, e

- o dos verbos com alteração da vogal ou consoante em SbPr.

Fique claro que esta divisão não é exatamente a proposta pelo lingüista, que não dá especial atenção à alternância vocálica de primeira conjugação, visto que:

As diferenças fonéticas, decorrentes da variação posicional das vogais como tônicas ou átonas, nas formas rizotônicas e nas arrizotônicas respectivamente, já estão pressupostas na estrutura fonológica da língua e não têm significação morfológica. [...] (Câmara Jr., 1975, p. 149)

Assim, atém-se apenas às alternâncias nos verbos de segunda e terceira conjugações com alternância vocálica (“com as raízes de vocalismo em vogal média aberta, na $2^{\text {a }}$

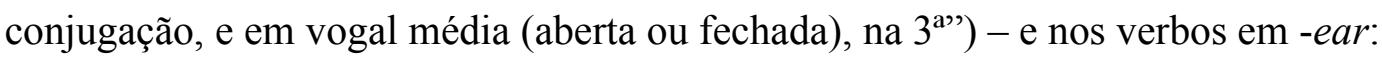

\footnotetext{
Ainda dentro de um princípio geral de "regularidade", há as alternâncias vocálicas, que ocorrem - 1) entre as formas rizotônicas e as formas arrizotônicas, 2) nas formas rizotônicas entre "a $2^{\mathrm{a}}$ pessoa singular e $3^{\mathrm{a}}$ singular e plural do indicativo presente, de um lado, e, de outro lado, na $1^{\mathrm{a}}$ pessoa singular associada ao subjuntivo presente. (Câmara Jr., 1975, p. 149)
}

Além disso, no terceiro padrão - constituído prioritariamente dos verbos que Câmara Jr. (1970, p.103) trata entre aqueles em que "às estruturas de R corresponde uma oposição entre $R$ e $R_{1}$ nas formas arrizotônicas. Ou seja: $R$ para $\mathrm{P} 2,3,6 \mathrm{IdPr}$, mas $\mathrm{R}_{1}$ para $\mathrm{Sb}_{2} \mathrm{Pr}$ (abrangendo as formas arrizotônicas de P4,5) e P1 IdPr." -, incluem-se, aqui, os verbos crer e ler, e os verbos em -air. 


\subsubsection{Primeiro Padrão: verbos da Primeira conJugaÇão com alternânCia Vocálica}

A alternância vocálica na primeira conjugação caracteriza-se pela identidade entre 1, 2, 3, $6 \mathrm{IdPr}$ e 1, 2, 3, $6 \mathrm{SbPr}$, dando-se entre as quatro formas rizotônicas e as arrizotônicas do IdPr, ou seja, entre:

- $\quad$ as vogais médias abertas /E/ e /[/ (levo, levas, leva, levam, e moro, moras, mora, moram p.ex.) e as médias fechadas /e/ e /o/ (levamos, levais e moramos, morais, p.ex.), e

- entre o ditongo /ej/ (receio, receias, receia, receiam, p.ex.), e a vogal média fechada /e/ (receamos, receais, p.ex.).

A estes últimos, juntam-se os verbos em -iar "que apresentam a mesma configuração fonológica, às vezes obrigatoriamente (cf.: odiar : odeio, odeias, etc.), outras vezes optativamente (cf.: negociar : negoceio, negoceias, etc.)" (Câmara Jr., 1972, p. 103-4), mostrando que a aparente irregularidade [...] se resolve numa questão ortográfica: escreve-se -iar, em fidelidade à pronúncia, quando há um nome cognato em -io ou -ia (odiar, por causa de ódio; negociar, por causa de negócio).

De fato, os outros poucos verbos em -iar que se conjugam como os em -ear também têm cognatos com /i/ radical (ansiar : ânsia, incendiar : incêndio, mediar : médio; remediar : remédio) e, ainda que isso não se verifique de forma nem sistemática (anunciar : anúncio, p.ex.), nem predominante (são centenas de verbos em -iar que não se ditongam nem obrigatoriamente, nem optativamente), não se pode ignorar a tendência para a ditongação no uso popular. ${ }^{16}$

Além da ditongação, dois verbos em -ear apresentam eventualmente abertura no timbre da vogal, igualmente verificada nos nomes:

$$
\begin{aligned}
& \text { [...] na derivação, a divergência entre idéia e ideal (o radical é ide-) e na formação } \\
& \text { do feminino uma palavra como européia em face do masculino europeu (houve a } \\
& \text { supressão da semivogal [em contato com outra vogal diversa] em seguida à } \\
& \text { ditongação pelo acréscimo do - } a \text { do feminino). [...] (Câmara Jr., 1972, p. 103-4) }
\end{aligned}
$$

Entretanto, é preciso observar que, diferentemente do que ocorre com a alternância dos verbos em -ear, a alternância nos verbos com vogais radicais $e$ e $o$ não se dá de forma

\footnotetext{
${ }^{16}$ Exemplo disso é o uso jocoso da expressão "aí vareia", que, pela força do hábito, acaba por fixar-se, como se vê fala extraída de blog: "Minha mãe deu um ataque comigo porque me perguntou alguma coisa e eu respondi aí vareia". Eu sempre falava com meus amigos de sacanagem, "aí vareia", mas acabou saindo errado quando era sério rs rs" (http://jornaljd.blogspot.com /2006/ 11/ saia-justa.html, 19/12/2006, 18:00).
} 
sistemática: ao lado de invejar (e outros poucos verbos), com /ع/ nas rizotônicas, há desejar (e outros tantos verbos), em que a vogal não se abre. Assim também, ao lado de pegar (e outros tantos verbos), há chegar (e derivados), em que a vogal também não se abre. Além disso, observa-se uso corrente das formas rizotônicas do verbo fechar com a vogal média aberta nas formas rizotônicas. ${ }^{17}$

\subsubsection{Segundo PADRão: VERbos das SEgunda E TERCEIRA CONJUGaÇÕES COM ALTERNÂNCIA VOCÁLICA}

A alternância vocálica na segunda conjugação caracteriza-se pela identidade entre 1 IdPr e SbPr, dando-se entre três formas rizotônicas, de um lado, e uma forma rizotônica e as arrizotônicas do IdPr, ou seja, entre as vogais:

- médias abertas /\&/ e / $/$ / (cedes, cede, cedem, e moves, move, movem, p.ex.) e as médias fechadas /e/ (cedo, cedemos, cedeis, e movo, movemos, moveis);

Com exceção de querer e poder - que apresentamalteração na consoante radical, fazendo parte, por isso, do terceiro padrão -, todos os outros verbos com vogal /e/ e /o/ orais no RI da segunda conjugação obedecem a este padrão.

Na terceira conjugação, considerando-se a harmonização vocálica (para a qual chama atenção Câmara Jr., 1972; 1970), o padrão de alternância é o mesmo da segunda, dando-se, agora, entre:

- as vogais médias abertas /\&/ e /[/ (feres, fere, ferem, e cobres, cobre, cobrem, bem como sobe, sobes, sobem, p.ex.) e as fechadas /i/ e /u/ (p.ex., firo, ferimos, feris, e cubro, cobrimos, cobris, bem como subimos, subis, p.ex);

- a vogal nasal média fechada /प̣/ (sentes, sente, sentem, p.ex.) e a nasal fechada / (sinto, sentimos, sentis, p.ex). ${ }^{18}$

A harmonização entre /e/ e /i/, /o e /u/, e /प̣/ e /प̣/ facilita em muito a compreensão da alternância vocálica na terceira conjugação, especialmente no caso de verbos como agredir que - consideradas a grafia e a possibilidade de pronúncia do e como /e/, e não /i/ - teriam de

\footnotetext{
${ }^{17}$ Como se poderá ver no Capítulo 3, item 3.3.1.2, há uma quantidade expressiva de verbos que nessa condição, ainda que não constituam a maioria dos verbos do subpadrão aqui fixado.

${ }^{18}$ Note-se que, nas outras duas conjugações, não há alternância nas vogais nasais porque não há, em português, vogal nasal aberta ou média aberta.
} 
ser incluídos no padrão anterior (agrido, agrides, agride, agridem, por oposição a agredimos, agredis), estranho aos outros verbos de sua conjugação.

De toda forma, é preciso notar que, no caso dos verbos com vogal /u/ no RI, a alternância vocálica de terceira conjugação também não é sistemática: ao lado de subir e construir (constróis, constróis, constroem, por oposição a construo, construímos, construis, ainda que consideradas as variantes construis, construi, construem) há verbos como curtir e instruir (sem alternância). ${ }^{19}$

\subsubsection{Terceiro Padrão: verbos com alterações no RI em SBPr}

A alteração da consoante radical é percebida na oposição entre "radical básico, da $2^{\mathrm{a}}$ pessoa singular do indicativo presente, e radical do presente subjuntivo (que nem sempre abrange a $1^{a}$ pessoa singular do indicativo presente)" (Câmara Jr., 1972, p. 112).

Um grupo de dezenove verbos - um da primeira conjugação (estar), catorze da segunda (caber, dizer, fazer, haver, perder, poder, pôr, querer, requerer, ser, ter, trazer, valer e ver) e quatro da terceira (medir, ouvir, pedir, vir) - caracteriza-se, em relação ao RI (que coincide, com o radical de $2 \mathrm{IdPr}$, exceto no caso de perder), por:

- troca isolada da consoante em $1 \mathrm{IdPr}$ e $\mathrm{SbPr}$ (dizer : digo, e diga, etc.; fazer : faço, e faça, etc.; ouvir : ouço, e ouça, etc.; perder : perco, perca, etc.; trazer : trago, e traga, etc.; dizer : valho, e valha, etc.) ou acompanhada de alternância vocálica (medir : meço, e meça, etc., pedir : peço, e peça, etc.; poder : posso, e possa, etc. $)^{20}$;

- travamento nasal em 1 IdPr e SbPr (pôr : ponho, ponha, etc.; ter : tenho, e tenha, etc.; vir : venho, e venha, etc.);

- acréscimo de consoante em 1 IdPr e SbPr (ver : vejo, e veja, etc.) ou apenas em SbPr (estar : estou, e esteja, etc.; haver : hei, e haja, etc.; ser : sou, e seja, etc.), e

- alargamento da vogal radical em 1 IdPr e SbPr (caber : caibo, e caiba, etc.; saber : sei, e saiba, etc., e requerer : requeiro, e requeira, etc.) ou apenas em $\mathrm{SbPr}$ (querer : quero, e queira, etc.).

\footnotetext{
${ }^{19}$, Como se poderá ver no Capítulo 3, item 3.3.3.1, a quantidade de verbos da terceira conjugação sem alternância vocálica é bem menos expressiva do que aquele que se verifica na primeira conjugação ${ }^{20}$ Para alguns desses verbos, Câmara Jr. (1975, p. 154) dá informações de natureza diacrônica: em poder, manteve-se "uma oposição latina (potes: possum)"; em dizer e trazer, o -c- latino $/ \mathrm{k} /$ passou a $/ \mathrm{g} /$ diante de -o e a /z/ diante de $-e$ ("dico $>$ digo, dices $>$ dizes"e traho $>\left[{ }^{*}\right.$ traco $]>$ trago, tracis $>$ trazes"). Em outros casos, o $i$ assilábico de -io, -iam mudou a natureza da consoante ("valeam, valeo $>$ valha, valho"; "video $>$ vejo, videam $>$ veja"; "facio > faço,faciam > faça"; *petio > peço; audio > ouço; *perdeo > perço > perco).
} 
Em relação à troca da consoante, convém notar que - acompanhando o padrão dos verbos de segunda conjugação com vogal /e/ no RI - perder não apresenta alternância vocálica $1 \mathrm{IdPr}$, enquanto, em medir, pedir e poder, a alternância atinge também $1 \mathrm{IdPr}-\mathrm{o}$ que caracteriza os verbos da primeira conjugação, e não os da segunda (a que pertence poder) e da terceira (a que pertencem medir e pedir).

$\mathrm{O}$ travamento nasal também atinge as três outras formas rizotônicas de pôr (pões, põe, põem), ter (tens, tem e têm) e vir (vens, vem e vêm).

Dentre os verbos com acréscimo de consoante em $\mathrm{SbPr}$, ver é o único que se comporta como aqueles em que há mudança isolada da consoante: $1 \mathrm{IdPr}$ e $\mathrm{SbPr}$ são afetadas (vejo, e $v e j a$, etc.). Nos outros, em que não há acréscimo de consoante em $1 \mathrm{IdPr}$, apenas hei apresenta alteração, que coincide com a dos verbos com alargamento da vogal radical.

Para haver e saber, Câmara Jr. (1972, p. 111-2) interpreta sincronicamente hei, "como uma forma radical haj- com a vocalização do /ž/ final e uma alternância /a/-/e/", e sei, "como uma redução do radical saib- e uma alternância /a/-/e/".

Também caber, saber, requerer —, apresentam ditongação da vogal radical em 1 IdPr e no SbPr. No verbo querer, conforme já se viu, a alternância vocálica de 1 IdPr não se repete em $\mathrm{SbPr}$, em cujas formas há ditongação tanto quanto em requerer. ${ }^{21}$

A este último grupo, juntam-se, aqui, verbos de segunda e terceira conjugações (crer e ler, e verbos em -air), que o autor trata de forma isolada.

Quando enuncia uma de suas regras morfofonêmicas, Câmara Jr. (1972, p. 105-6) alinha os verbos terminados em -air aos terminados em -oer e -uir:

As vogais temáticas /e/ e /i/, com a oposição neutralizada nas formas rizotônicas, passam a semivogal /y/ em contacto com uma vogal diversa do radical, com a qual portanto se ditongam.

Daí, róis ou móis, para roer ou moer, atrais ou instruis, para atrair e instruir, e todos os demais verbos de estrutura fonológica análoga, que certas gramáticas colocam entre os "irregulares" por causa da letra -i-, representando /y/, em vez de -e, que em posição átona final corresponde à neutralização da oposição /e/-/i/.

É preciso observar, porém, que, em atrair, há ditongação não só em $3 \mathrm{IdPr}$, mas também em $1 \operatorname{IdPr}$ (caio), que se repete em $\mathrm{SbPr}$ de (caia, etc.) - o que não se verifica nem em roer (rôo, e roa, etc.), nem em instruir (instruo, e instrua, etc.).

\footnotetext{
${ }^{21}$ SbPrCâmara Jr. (1975, p. 155) mostra que o $i$ assilábico de capiam "se transpôs para a sílaba precedente, dentro do movimento geral para a eliminação dos ditongos crescentes que se tinham temporariamente constituído em latim vulgar”.
} 
Verifica-se o mesmo em ler e crer, para os quais vale a mesma regra morfofonêmica que explica a ditongação nos verbos em -ear, mas "na segunda conjugação, em vez do que acontece na primeira, esta ditongação se estende às formas arrizotônicas de $\mathrm{P} 4,5$ de $\mathrm{Sb}_{2} \mathrm{Pr}$ : leiamos, leiais; creiamos (cf. ao contrário - passeemos, passeeis)", como observa Câmara Jr. $\left(1970\right.$, p. 100). ${ }^{22}$

\subsubsection{PAdRão ESPECIAL PARA O GRUPO do PERFEITO}

Com exceção de perder, valer, medir, ouvir, pedir, todos os verbos do segundo subpadrão para o grupo do presente encaixam-se no padrão especial para o grupo do perfeito $\left(\mathrm{IdPt}_{2}, \mathrm{IdPt}_{3}, \mathrm{SbPt}\right.$ e SbFt), que se caracteriza por variação na VT do RI, e no SNP de 1,3 $\mathrm{IdPt}_{2}$. Doze desses verbos - onze da segunda conjugação (caber, dizer, fazer, haver, poder,

pôr, prazer, querer, saber, trazer, ter e vir) e um da primeira (estar) - apresentam vocalismo em:

- Low/, seja com manutenção da consoante final (caber : coube, etc.; haver : houve, etc., e saber : soube, etc.), seja com alteração (prazer : prouve, etc.; e trazer : trouxe, etc.); ${ }^{23}$

- /i/, com mudança da consoante final (dizer : disse, etc., e querer: quis, etc.);

- /i/:/e/, seja com manutenção da consoante final (fazer : fiz : fez), seja com acréscimo (estar : estiveste : esteve, ter : tiveste : teve), seja com alteração na vogal (vir : viestes : veio), e

- /u/:/o/, seja com manutenção da consoante (poder : pudeste : pôde), seja com acréscimo (pôr : pus : pôs).

É preciso notar que, com exceção do verbo vir, as alternâncias vocálicas marcam $3 \mathrm{IdPt}_{2}$ em relação a todas as outras formas do grupo do perfeito $\left(1,2,4,5,6 \mathrm{IdPt}_{2} ; \mathrm{IdPt}_{3} ; \mathrm{SbPt}\right.$, e $\mathrm{SbFt}$ ), conforme se pode ver no Quadro 1.6.

\section{Quadro 1.6 - Verbos COM ALternânCia VOCÁlica EM IDPT}

\begin{tabular}{|c|c|c|c|c|c|c|c|}
\hline alternância entre & & & & & & alternância entre & \\
\hline $3 \mathrm{IdPt}_{2}$ & $/$ estev & $/ \mathrm{fez} /$ & $/ \mathrm{pod} /$ & $/ \mathrm{poz} /$ & $/$ tev/ & $1 \mathrm{IdPt}_{2}$ & $/ \mathrm{ve} /$ \\
\hline
\end{tabular}

\footnotetext{
${ }^{22}$ Said Ali (1931: 148-50) registra: "Na $1^{\text {a }}$ singular evitou-se o ditongo que proviria do acréscimo direto de -o aos radicais acabados em vogal, inserindo o fonema $i$ (iota) caio, creio, seio e leio."

${ }^{23}$ No caso do unipessoal prazer, a vogal temática / $\varepsilon /$ da forma teórica (*prouveste) reflete-se em $6 \mathrm{IdPt}_{2}, 3,6$ $\mathrm{IdPt}_{3}, \mathrm{SbPt}$ e SbFt.
} 


\begin{tabular}{l|l|l|l|l|l|l|l} 
outras formas & /estiv/ & /fiz/ & /pud/ & /puz/ & /tiv/ & outras formas & /vi///vĩ \\
\hline
\end{tabular}

Ver distingue-se dos outros verbos pelo fato de que a forma marcada é $\operatorname{IdPt}_{2}$ (veio), em que a vogal radical se ditonga, por oposição a todas as outras formas, considerando-se que, em1 $\mathrm{IdPt}_{2}$ (vim), o radical conserva o travamento nasal verificado em $\operatorname{IdPr}$ (venho, vens, etc.), $\mathrm{SbPr}$ (venha, venhas, etc.) e, também, em Id Pt1 (vinha, vinhas).

Assim como nos outros oito verbos, a VT (dada por $2 \mathrm{IdPt}_{2}$ ) é a vogal média aberta tônica $/ \varepsilon /$, que pode ser:

- em 1,3 $\mathrm{IdPt}_{2}$, média fechada átona $e$ (para a maioria dos verbos) ou Ø (em fiz, fez e pus, pôs), e

- $\quad$ em $4 \mathrm{IdPt}_{2}$, média fechada tônica $e$, como no padrão geral.

No Quadro 1.7, comparam-se a estrutura do padrão geral da segunda conjugação (p.ex., vender) e a dos verbos do padrão especial para o grupo do perfeito (p.ex., caber), destacando-se os alomorfes não coincidentes. 


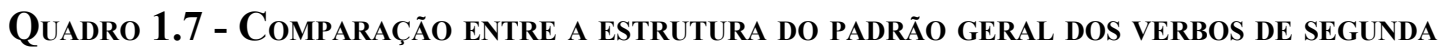
CONJUGAÇÃo E do PADRÃo ESPECIAL PARA O GRUPO DO PERFEITO

\begin{tabular}{|c|c|c|c|c|c|c|c|c|c|c|c|c|c|}
\hline \multirow{2}{*}{ padrão } & \multirow{2}{*}{ pessoas } & \multicolumn{3}{|c|}{$\mathrm{IdPt}_{2}$} & \multicolumn{3}{|c|}{$\mathrm{IdPt}_{3}$} & \multicolumn{3}{|c|}{$\mathrm{SbPt}$} & \multicolumn{3}{|c|}{$\mathrm{SbFt}$} \\
\hline & & VT & SMT & SNP & VT & SMT & SNP & VT & SMT & SNP & VT & SMT & SNP \\
\hline \multirow{6}{*}{$\left.\underset{\left(2^{\mathrm{a}} \text { conj. }\right.}{\text { geral }}\right)$} & 1 & /'i/ & $\varnothing$ & $(/ \mathrm{j} /)$ & /'e/ & /प्र/ & $\varnothing$ & /'e/ & $/ \mathrm{se} /$ & $\varnothing$ & /'e/ & /[// & $\varnothing$ \\
\hline & 2 & /'e/ & $\varnothing$ & /ste/ & /'e/ & /प्र/ & $/ \mathrm{s} /$ & /'e/ & $/ \mathrm{se} /$ & $/ \mathrm{s} /$ & /'e/ & /पए/ & /s/ \\
\hline & 3 & /'e/ & $\varnothing$ & $/ \mathrm{w} /$ & /'e/ & /पए।/ & $\varnothing$ & /'e/ & $/ \mathrm{se} /$ & $\varnothing$ & /'e/ & /D/ & $\varnothing$ \\
\hline & 4 & /'e/ & $\varnothing$ & $/ \mathrm{mos} /$ & /'e/ & /पए/ & $/ \mathrm{mos} /$ & /'e/ & $/ \mathrm{se} /$ & $/ \mathrm{mos} /$ & /'e/ & /[1/ & $/ \mathrm{mos} /$ \\
\hline & 5 & /'e/ & $\varnothing$ & /stes/ & /'e/ & /प्र/ & /is/ & /'e/ & $/ \mathrm{se} /$ & /is/ & /'e/ & /[]/ & /is/ \\
\hline & 6 & /'e/ & /प्य/ & $/{ }^{\prime \prime} \mathrm{N} /$ & /'e/ & /प्य/ & $/{ }^{4} \mathrm{~N} /$ & /'e/ & $/ \mathrm{se} /$ & $/ \mathrm{N} /$ & /'e/ & /पू/ & $/ \mathrm{N} /$ \\
\hline \multirow{6}{*}{$\begin{array}{l}\text { especial } \\
\text { para o } \\
\text { grupo do } \\
\text { perfeito }\end{array}$} & 1 & $/ \mathrm{e} /$ & $\varnothing$ & $\varnothing$ & /'छ/ & /प्य/ & $\varnothing$ & /'\&/ & $/ \mathrm{se} /$ & $\varnothing$ & /'E/ & /[/ & $\varnothing$ \\
\hline & 2 & /'\&/ & $\varnothing$ & /ste/ & /'\&/ & /पए/ & $/ \mathrm{s} /$ & $\mid ' \varepsilon /$ & $/ \mathrm{se} /$ & $/ \mathrm{s} /$ & /'\&/ & /प्य/ & $/ \mathrm{s} /$ \\
\hline & 3 & $/ \mathrm{e} /$ & $\varnothing$ & $\varnothing$ & /'E/ & /प्र/ & $\varnothing$ & $/ ' \varepsilon /$ & $/ \mathrm{se} /$ & $\varnothing$ & /'\&/ & /[// & $\varnothing$ \\
\hline & 4 & /'e/ & $\varnothing$ & $/ \mathrm{mos} /$ & /'\&/ & /प्य/ & $/ \mathrm{mos} /$ & $/ ' \varepsilon /$ & $/ \mathrm{se} /$ & $/ \mathrm{mos} /$ & /'\&/ & /[// & $/ \mathrm{mos} /$ \\
\hline & 5 & $\mid ' \varepsilon /$ & $\varnothing$ & /stes/ & /'E/ & /प्र/ & /is/ & /'\&/ & $/ \mathrm{se} /$ & /is/ & /'E/ & /[// & /is/ \\
\hline & 6 & /'\&/ & /प्य/ & $/{ }^{\prime \prime} \mathrm{N} /$ & /'E/ & /प्रा/ & $/{ }^{\prime \prime} \mathrm{N} /$ & $/ ' \varepsilon /$ & $/ \mathrm{se} /$ & $/ \mathrm{N} /$ & /'\&/ & /प्र/ & $/ \mathrm{N} /$ \\
\hline
\end{tabular}

Como ocorre com a VT - $e$ átono em $1 \operatorname{IdPt}_{2}$ (e não $i$ tônico) e em $3 \operatorname{IdPt}_{2}$ (e não $e$ tônico) e $e$ médio aberto em $2 \operatorname{IdPt}_{2}$ (e não médio fechado) -, não há coincidência de SNP em 1, $3 \mathrm{IdPt}_{2}$. É curioso que, nestes verbos, o morfema zero caracterize o SNP de 1,3 $\mathrm{IdPt}_{2}$ (no lugar de $i$ e $u$ assilábicos, respectivamente, do padrão geral) tanto quanto em 1,3 $\operatorname{IdPt}_{3}, 1,3$ $\mathrm{SbPt}$ e 1,3 SbFt - de forma mais uniforme, portanto, que no caso dos verbos regulares.

Mais importante é a confirmação de que, pelo fato de a VT /E/, dada por $2 \mathrm{IdPt}_{2}$, caracterizar o sistema flexional para o grupo do perfeito assim como pelo fato de repetir-se nos outros três tempos,

[...] muito se simplifica a descrição dos verbos irregulares se nos prendermos exclusivamente às formas primitivas; as formas derivadas só devem ser mencionadas quando, excepcionalmente, não se enquadram no processo acima indicado [a repetição do radical de $2 \mathrm{IdPt}_{2} \mathrm{em} \mathrm{IdPt}{ }_{2}, \mathrm{SbPt}$ e SbFt]. Dessa forma, é desnecessária a especificação dos tempos em que o RP se realiza [...]. (Kehdi, 1998, p. 130)

Verbos monossilábicos que não se encaixam perfeitamente neste padrão - seja por não terem variação no RI (dar e ver), seja por não terem VT (ir e ser) - serão vistos neste Capítulo, item 1.5.

\subsubsection{Padrão especial para o PARTicípio}

A estrutura mórfica do particípio português caracteriza-se pela forma invariável do radical do infinitivo, ao qual se soma a VT característica de Pa em cada uma das conjugações (/a/, para a primeira, e /i/, para a segunda e a terceira) e pelo SMT -do. 
Paralelamente, há os particípios que Câmara Jr. (1968, verbete defectivos) classifica como "irregulares", de dois tipos:

[...] 1) com um radical variante, em face do infinitivo, e a vogal temática nominal (ex.: preso, cf. prender, dito, cf. dizer, feito, cf. fazer; 2) com o radical do infinitivo e a vogal temática (ex.: aceito, aceitar; ganho, ganhar; entregue; entregar. [...] Às vezes concorrem para o mesmo verbo, o particípio regular e o irregular [...]

Em Câmara Jr. (1970, p.103-4), esses dois tipos de particípio constituem os "padrões especiais" do particípio, o primeiro formado "na base do radical do infinitivo" e o segundo, "na base de um alomorfe do radical do infinitivo". O autor organiza, então, duas listas, observando que "algumas gramáticas aumentam a lista, incluindo formas que são na realidade nomes adjetivos cognatos do verbo".

Nas três conjugações, a VT caracaterística desses particípios é /o/, com variante /e/, conforme se pode ver no Quadro 1.8. 
Quadro 1.8 - Particípios com Particularidades na estrutura Verbal

\begin{tabular}{|c|c|c|c|c|c|}
\hline & RI variável & RI invariável & & RI variável & RI invariável \\
\hline expulsar & expulso & expulsado & entregar & entregue & entregado \\
\hline fritar & frito & fritado & expressar & expresso & expressado \\
\hline ganhar & ganho & ganhado & enxugar & enxuto & enxugado \\
\hline gastar & gasto & gastado & matar & morto & matado \\
\hline pagar & pago & pagado & \multirow{5}{*}{\multicolumn{3}{|c|}{$\frac{\Delta}{1^{\mathrm{a}} \text { conjugação }}$}} \\
\hline salvar & salvo & salvado & & & \\
\hline soltar & solto & soltado & & & \\
\hline aceitar & aceito/aceite & aceitado & & & \\
\hline assentar & assente & assentado & & & \\
\hline & \multirow{9}{*}{\multicolumn{2}{|c|}{$2^{\mathrm{a}}$ conjugação }} & eleger & eleito & elegido \\
\hline & & & morrer & morto & morrido \\
\hline & & & prender & preso & prendido \\
\hline & & & suspender & suspenso & suspendido \\
\hline & & & dizer & dito & \\
\hline & & & fazer & feito & \\
\hline & & & escrever & escrito & \\
\hline & & & $p \hat{o r}$ & posto & \\
\hline & & & ver & visto & \\
\hline & \multirow{5}{*}{\multicolumn{2}{|c|}{$3^{\mathrm{a}}$ conjugação }} & frigir & frito & frigido \\
\hline & & & exprimir & expresso & exprimido \\
\hline & & & imprimir & impresso & imprimido \\
\hline & & & abrir & aberto & \\
\hline & & & cobrir & coberto & \\
\hline
\end{tabular}

É notável que quase metade dos verbos (treze) elencados por Câmara Jr. (1975, 1970) sejam da primeira conjugação; dez, da segunda, e cinco, da terceira - denunciando, mais uma vez, a oposição entre a primeira e as duas outras conjugações.

Além disso, todos os verbos da primeira conjugação têm duas formas de particípio: uma que se encaixa no padrão geral (p.ex., expulsado), eventualmente com uma terceira forma, também do padrão especial (p.ex., aceite). Na segunda conjugação, são apenas quatro verbos: dois por alternância vocálica (entregado/entregue e expressado/expresso), um por troca de consoante (enxugado/enxuto) e um por cruzamento com morrer (matado/morto). ${ }^{24}$

Nas duas outras conjugações, os particípios são do padrão especial, ainda que alguns deles (eleito, p.ex.) convivam com outras do padrão (elegido, p.ex.). Além disso,

\footnotetext{
${ }^{24}$ Segundo Câmara Jr. (1975, p. 161), morto é "nome adjetivo, proveniente do particípio perfeito latino do verbo mori, "morrer", que a partir do português clássico, em vez de ser associado ao verbo correspondente português morrer (cujo particípio é o português morrido), foi atribuído ao verbo matar em variação livre com matado.
} 
os verbos que se encaixam apenas no padrão especial são necessariamente da segunda conjugação (dizer : dito, fazer : feito. escrever : escrito, pôr : posto, ver : visto) ou terceira (abrir : aberto. cobrir : coberto).

Convém chamar atenção para o fato de que a vogal radical de alguns destes verbos apresenta alteração na vogal radical por alternância vocálica (exprimir/expresso; abrir/aberto; cobrir : coberto) ou ditongação (eleger/eleito, fazer/feito).

Salienta-se, ainda, a observação de Câmara Jr. (1975, p. 160) sobre vindo, “onde a queda de /n/ entre vogais, com nasalação, impediu a manutenção de um final -ido, como nos demais verbos de tema em - $i$ " - o que mostra que esse particípio obedece à estrutura do padrão geral, com a única ressalva de que a vogal temática recebe travamento nasal (tanto quanto em vens, vinha, vinhas, etc. e vim).

\subsection{Particularidades na estrutura dos verbos monossilábicos}

Serão analisados, primeiramente, os desvios no padrão especial para o grupo do presente e, em seguida,os desvios no padrão especial do grupo do perfeito.

\subsubsection{Desvios No TERCEIRO PADRÃo ESPECIAL PARA O GRUPO DO PRESENTE}

Os verbos ser e ir têm radicais supletivos: no primeiro, "um radical básico / $/$ / alterna com /se/"; no segundo, "um radical básico /i/ alterna com /va/" (Câmara Jr, 1972, p. 113-4).

Segundo o autor, no verbo ser, o radical /E/ de 2,3 $\operatorname{IdPr}(e ́ s$, é) sofre variação por acréscimo de consoante: $/ \varepsilon \mathrm{\varepsilon} / \mathrm{em} \operatorname{IdPt} 1$ (era, etc.), enquanto o radical /se/ de If (ser), $\mathrm{IdFt}_{1}$ (serei, etc.), $\mathrm{IdFt}_{2}$ (seria, etc.), Gr (sendo), também sofre variações por mudança de consoante (sou, somos, sois, e sãa) e por acréscimo de consoante (seja, sejas, etc), conforme se viu neste Capítulo, item 1.4.1.3.

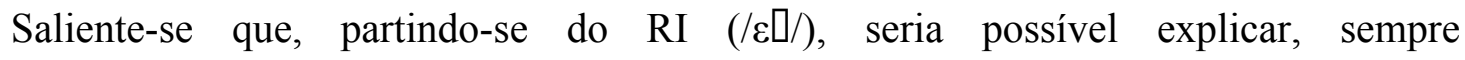
sincronicamente, a perda da consoante radical em és, é, com crase entre a consoante radical $/ \varepsilon /$ e a vogal temática /e/ do verbo de segunda conjugação.

Em ir, o radical /va/ de 2,3,4, $6 \operatorname{IdPr}$ (vais, vai, vamos, vão) e $\operatorname{SbPr}$ (vá, vás, etc.) sofre variação por alternância vocálica: /vo/ em $1 \operatorname{IdPr}(v o u)$, enquanto o radical /i/ em If (ir), $5 \operatorname{IdPr}$ (ides), $\operatorname{IdPt}_{1}$ (ia, etc.), $\operatorname{IdFt}_{1}$ (irei, etc.), $\mathrm{IdFt}_{2}$ (iria, etc.), Gr (indo), $5 \operatorname{SbPr}_{2}$ (ide) não sofre variação. 
Convém mencionar que, em vai, vais, a VT torna-se semivogal quando em contato com uma vogal diversa (tanto quanto em instrui, instruis) e que, em vão, a nasalização do $a$ em sílaba tônica, pelo SNP de $6 \mathrm{IdPr}$, ditonga a vogal (tanto quanto em cantarão, venderão, partirão). Nas outras formas, há crase entre a vogal radical /i/ e a VT/i/, sendo que em $\mathrm{IdPt}_{1}$ (ia, etc.), essas duas vogais craseadas se fundem com SMT (tanto quanto em partia, etc.).

Embora coincidam com 1,6 IdPr de ser e ir, as mesmas formas dos verbos dar e estar são explicadas por Câmara Jr. (1972, p. 105) por meio de uma regra morfofonêmica, segundo a qual:

\footnotetext{
Nas formas monossilábicas, a vogal temática ou flexional, que teoricamente seria átona, fica tônica e o seu timbre muda em conseqüência.

É por isso que se tem dás em face de cantas, cantam, ou dês, dê em face de cantes, em cante. Igualmente em dão há o ditongo tônico correspondente ao ditongo átono de cantam, isto é, SNP correspondente a uma semivogal $/ \mathrm{w} /$ mais o travamento nasal, porque se acrescenta a /a/ [...]. Até em dou, com a pronúncia literária e inusual /dow'/ (em vez da corrente /do'), o que se encontra é a contraparte tônica do -o átono final [...]. Mesmo estou, estás, está, estão se situam dentro dessa regra fonológica, se considerarmos que o genuíno radical é st- e que o $e$ - (/i/) inicial é um desenvolvimento secundário, decorrente da exclusão, na fonologia portuguesa, de /st/ inicial [...]
}

Isso só não ocorre com verbos de segunda e terceira conjugações em que há ditongação da vogal radical em 1 IdPr (leio, e leia, etc; creio, e creia, etc), acréscimo de consoante com travamento por consoante nasal palatal (ponho, e ponha, etc; tenho, e tenha, etc; venho, e venha, etc), ou simples acréscimo de consoante (vejo), conforme se pode ver no no Quadro 1.9, onde está incluído o verbo rir, que mantém apenas em 1 IdPr a vogal radical do verbo latino. 
Quadro 1.9 - Formas de IdPr dos verbos monossilábicos

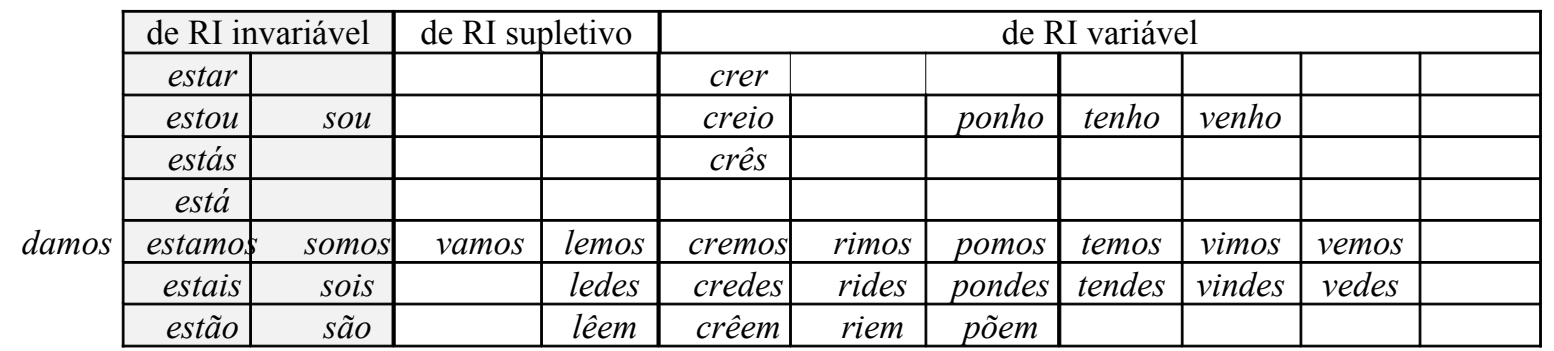

O radical de pôr, ter e vir também é travado por consoante nasal palatal em $\operatorname{IdPt}_{1}$ com alternância para vogal média fechada (punh-, tinh-, vinh-). Em $\mathrm{IdFt}_{1}, \mathrm{IdFt}_{2} \mathrm{e}$ If, os radicais $p o(n), t e(n)$ e $v e(n)$ - com alternância para $v i(n)$ - perdem o travamento nasal, resultando em formas (po-, te- e vi-), que só recebem VT em pões e põe.

Em 6 IdPr de ler, crer e ver, a tônica incide sobre a raiz, tanto quando em vendem - e riem. Em têm e vêm, há crase da vogal radical com VT, marcada graficamente pelo acento. Em 2,3 IdPr de todos os outros verbos, o radical também permanece monossilábico: em ler, crer, ver e rir, exatamente como em dá. Em ir, como já se viu, a VT passa a /j/, pelo contato com a vogal radical, como em cair.

Outra particularidade a ser notada é que a freqüência de /des/ na forma de $5 \operatorname{IdPr}(\mathrm{em}$ sete verbos, por oposição a dais, estais e sois) mostra que este alomorfe - encontrado em 5 SNP de SbFt e If do dos verbos do padrão geral (p.ex., venderdes) e também do padrão especial para o grupo do perfeito (p.ex., couberdes e caberdes, respectivamente) - é predominante nos verbos monossilábicos.

Isso talvez explique por que Câmara Jr. (1975, p. 147) incluiu -des (que, em Câmara Jr. (1972), conforme se viu em 1.2, é considerado irregularidade flexional) no quadro geral dos sufixos número-pessoais ou desinência de pessoa":

\footnotetext{
$2^{\mathrm{a}}$ pl. -stes: Indicativo pretérito perfeito (amastes; temestes; partistes)

-des: Subjuntivo futuro e infinitivo pessoal (amarDEs; temerDEs; partirDEs)

Indicativo presente, em raízes monossilábicas terminadas em -e, na $2^{\mathrm{a}}$ conjugação e -i, na $3^{\mathrm{a}}$, ou por travamento nasal (leDES; iDES; ponDES) Imperativo, nas mesmas condições, e com a supressão do -s final (leDE; iDE; ponDE)
}

-is/is/: em todos os demais tempos; no Imperativo, com a supressão do -s final 


\subsubsection{Desvios nO PADRÃo ESPECIAL PARA O GRUPO dO PERFEITO}

Resta comparar o comportamento de caber (que representa o padrão especial para o grupo do perfeito), com quatro verbos monossilábicos, dentre os quais dois não têm variação no radical e outros dois não têm VT /\&/, conforme se pode ver no Quadro 1.10, onde se destacam as formas não coincidentes.

Quadro 1.10 - ComparaÇão entre o COMPORTAMENTo de CABER E DaR, VER, IR E SER

\begin{tabular}{|c|c|c|c|c|c|c|c|c|c|c|c|c|c|c|c|}
\hline & \multicolumn{3}{|c|}{ caber } & \multicolumn{4}{|c|}{$d a r$} & \multicolumn{4}{|c|}{ ver } & \multicolumn{4}{|c|}{ ir e ser } \\
\hline $\mathrm{RP}$ & $\begin{array}{l}\mathrm{V} \\
\mathrm{T}\end{array}$ & SMT & SNP & RI & VT & SMT & SNP & RI & VT & SMT & SNP & RP & VT & SMT & SNP \\
\hline \multirow{6}{*}{ /koub } & /e/ & $\varnothing$ & $\varnothing$ & \multirow{6}{*}{$/ \mathbf{d} /$} & $/ \mathrm{e} /$ & $\varnothing$ & $/ \mathbf{j} /$ & \multirow{6}{*}{$/ \mathbf{v} /$} & $/ / \mathbf{i} /$ & $\varnothing$ & $/ \mathbf{j} /$ & /fu/ & $\varnothing$ & $\varnothing$ & $/ \mathbf{j} /$ \\
\hline & $/$ /'E/ & $\varnothing$ & /ste/ & & $/{ }^{\prime} \varepsilon$ & $\varnothing$ & $/$ ste/ & & $/ / \mathbf{i} /$ & $\varnothing$ & $/$ ste/ & \multirow{5}{*}{ /fo/ } & $\varnothing$ & $\varnothing$ & $/$ ste/ \\
\hline & $/ \mathrm{e} /$ & $\varnothing$ & $\varnothing$ & & $/ \mathrm{e} /$ & $\varnothing$ & $/ \mathrm{w} /$ & & $/ / \mathbf{i} /$ & $\varnothing$ & $/ \mathbf{w} /$ & & $\varnothing$ & $\varnothing$ & $/ \mathbf{j} /$ \\
\hline & $/$ 'e/ & $\varnothing$ & $/ \mathrm{mos} /$ & & $/ / \mathrm{e} /$ & $\varnothing$ & $/ \mathrm{mos}$ & & /'i/ & $\varnothing$ & $/ \mathrm{mos} /$ & & $\varnothing$ & $\varnothing$ & $/ \mathrm{mos} /$ \\
\hline & /'E/ & $\varnothing$ & /stes/ & & /' & $\varnothing$ & $/$ stes/ & & $/ / \mathbf{i} /$ & $\varnothing$ & /ste/ & & $\varnothing$ & $\varnothing$ & $/$ ste/ \\
\hline & /'/' & $/ \overline{\mathrm{a}} /$ & $/{ }^{\mathrm{u}} \mathrm{N} /$ & & /' & //प/ & $/{ }^{\mu} \mathrm{N} /$ & & /'i/ & $/ \bar{a} /$ & $/{ }^{\mu} \mathrm{N} /$ & & $\varnothing$ & $/ \sqrt{\mathrm{a} /}$ & $/{ }^{\mathrm{u}} \mathrm{N} /$ \\
\hline
\end{tabular}

Dar, da primeira conjugação, apresenta a VT do padrão especial do perfeito, mas mantém o RI nos tempos do grupo do perfeito. Ou seja: o radical e o SNP são do padrão geral, mas a VT é do padrão especial para o perfeito.

Também em ver, permanecem o RI e o SNP do padrão geral, mas a VT do verbo da segunda conjugação comporta-se como a dos verbos da terceira: “em ve- há a crase do radical ve- com a vogal temática; em vi-, a supressão da vogal do radical, átona, com a adjunção da vogal temática, tônica, /i/” (Câmara Jr., 1972, p. 108).

Os verbos ser e ir têm um outro radical supletivo /fo/, com variante /fu/ apenas em 1 $\mathrm{IdPt}_{2}$, além de terem 1,3 $\mathrm{IdPt}_{2}$ igualmente marcados, desta vez pelo $i$ assilábico não só em foi, mas também em fui.

\subsection{Considerações finais}

Não resta dúvida de que a análise mórfica proposta pelo autor contribui enormemente para a compreensão da estrutura verbal em português e, portanto, para a fixação das formas verbais, por parte dos falantes de português como língua materna ou estrangeira.

Como argumenta Hockett (1967, p. 148), se estudar as palavras sem dar importância à combinação dos morfemas fosse uma verdade, 
[...] então tudo o que teríamos de aprender ao estudar uma língua estrangeira seriam os morfemas individuais e seu significado. O significado de qualquer enunciado completo ficaria imediatamente claro com base no significado dos constituintes fundamentais. ${ }^{25}$

Não tivesse o lingüista brasileiro identificado os morfemas do verbo por meio da comparação de seus alomorfes nos diferentes modos e tempos e nas diferentes pessoas, valendo-se muitas vezes do auxílio de regras morfofonêmicas estabelecidas em contraste com outras categorias gramaticais, não teria sido possível caracterizar os diferentes padrões verbais, que, neste trabalho, foram organizados de forma um diferente da proposta por Câmara Jr. (1972, 1970):

- padrão geral, caracterizado por RI invariável, bem como por alomorfes claramente determinados para a VT, o SMT e o SNP fonologicamente condicionados;

- três padrões especiais para o grupo do presente, caracterizados por variações no RI (alternância vocálica na primeira conjugação; alternâncias vocálicas nas duas outras conjugações; alterações no RI em SbPr);

- padrão especial para o grupo do perfeito, caracterizado por RI variável em $\mathrm{IdPt}_{2}$,

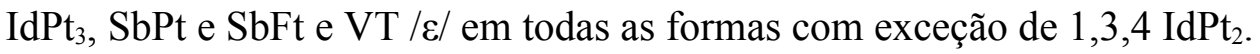

É importante constatar a inexistência de SMT que se afaste dos estabelecidos no padrão geral, havendo alguns desvios na VT (zero em quer, faz, diz, produz) e no SNP (-des para 5 IdPr em verbos monossilábicos), que não merecem ser chamados de propriamente de irregularidades. Se assim não fosse, o próprio lingüista Câmara Jr. (1975) não teria incluído o sufixo -des no quadro geral dos sufixos número-pessoais. Com relação à supressão da VT, viu-se que é explicável nas formas teóricas encontrando paralelo na flexão nominal.

A identificação da regularidade interna nos padrões especiais do presente, p.ex., permite que se veja como desvios a ausência de alternância vocálica em determinados verbos, ou ainda a falta de identidade entre 1 IdPr e SbPr em verbos como saber (em relação a caber).

Isso ratifica a afirmação de que muitas vezes a irregularidade é apenas aparente, resultando da aplicação de regras não percebidas, formuladas por Marouzeau (1943), que propõe, porém, uma solução que não resolve o problema: a substituição de irregular por

\footnotetext{
${ }^{25}$ No original, "[...] then all we would have to learn in studying a foreign language would be the individual morphemes and their meanings. The meaning of any whole utterance would be immediately obvious on the basis of the meanings of the ultimate constituents."
} 
anômalo - termos encontrados nas gramáticas normativas, que serão vistos no Capítulo 2, item 2.1.3.

É compreensível, portanto, a hesitação de Câmara Jr. (1975, 1972, 1970) com relação à rotulação dos verbos em regulares ou irregulares. Com relação aos verbos com alternância vocálica, no entanto, não parece que essa hesitação se justifique, senão nos casos dos verbos que não sofrem alternância vocálica. Isso ficará comprovado no Capítulo 3, itens 3.3.1.2 e 3.3.3.1, onde o levantamento quantitativo desses verbos mostrará a predominância de verbos com alternância vocálica, em maior ou menor grau, em cada uma das três conjugações.

Nos textos examinados neste Capítulo, o lingüista não trata dos verbos defectivos, privados de algumas ou todas as formas rizotônicas do presente do indicativo, as correspondentes do imperativo e do subjuntivo presente, mas em Câmara Jr. (1968, verbete defectivos) há considerações importantes para a morfologia verbal, conforme se pode ver em:

É na terceira conjugação que há um número bastante apreciável de verbos defectivos. A inexistência de flexão é uma questão de desuso, o que faz essa flexão ser abolida na norma lingüística e ser considerada contrária à eufonia. Mas, como a flexão está prevista na estrutura das oposições flexionais, pode aparecer esporadicamente quer na língua corrente, quer na língua literária. [...].

Convém não confundir com os verbos defectivos os impessoais e os unipessoais, que, em virtude de sua significação e aplicação, só têm $3^{\mathrm{a}}$ pessoa.

Levando-se em conta a possibilidade de conjugação das formas rizotônicas em verbos que não têm o comprometimento de sentido dos verbos impessoais e unipessoais - ou seja, que podem ser usados em qualquer pessoa de todos os modos e tempos por mais estranho que soem -, no Capítulo 2 será feito um estudo dos verbos defectivos, que são prioritariamente da terceira conjugação, como observa o lingüista.

Ressaltada a enorme contribuição do autor para a compreensão da estrutura verbal em português, não se pode deixar de mencionar as dificuldades encontradas, por problemas de edição, quando do cotejo dos textos aqui examinados. A oscilação na fixação das siglas e a omissão, embora rara, de trechos de texto tornam sua exposição, especialmente nas publicações póstumas (Câmara Jr., 1972; 1970), pouco acessível a professores de língua portuguesa, "a quem cabe a manipulação didática da nossa exposição, inclusive a organização de exercícios práticos, baseados nas oposições e correlações formais que aqui se apresentam”, lembrando mais uma vez as palavras de Câmara Jr. (1972, p. 114). 
$\mathrm{Na}$ tentativa de tornar mais claras essas oposições e correlações formais é que se elaboraram os Quadros 1.3, 1.4 e 1.5, onde se pretendeu tornar graficamente visualizáveis os morfemas da VT, SMT e SNF que caracterizam o padrão geral, em cada um dos modos, tempos e pessoas do verbo. Assim também, com a seqüência dos Quadros 1.6 a 1.10, pretendeu-se evidenciar graficamente as particularidades dos padrões especiais. 


\section{Capítulo 2}

\section{Morfologia do verbo em gramáticas e manuais de CONJUgaÇão Verbal}

De acordo com a organização que os autores das gramáticas deram ao tema, cinco dos textos examinados constituem partes do capítulo intitulado:

- "Verbo", em Bechara (1999, 1975);

- "Verbo", em Cunha; Cintra (1985);

- “Das Prädikat” [O predicado], em Gärtner (1998a);

- "O grupo do verbo: verbo e advérbio", em Masip (2000), e

- "O verbo", em Vázquez Cuesta; Mendes da Luz (1980; 1961).

Os quatro restantes correspondem a capítulos inteiros:

• "Il verbo", além dos anexos "Coniugazione dei verbi ausiliari", "Coniugazione dei verbi regolari", "Coniugazione pronominale", "Coniugazione della voce passiva" e “Coniugazione dei principali verbi irregolari”, em Abreu; Murteira (1998);

- "Verbs", em Hutchinson; Lloyd (2002);

- "The Verb" e "Irregular Verbs", além dos apêndices "Regular Verbs" e "Irregular and Anomalous Verbs, em Perini (2002), e

- "Morphologie du verbe", em Teyssier (1984).

Em Lopes (1992), Rodrigues (2003) e Ryan (1991), foram examinadas apenas as tábuas de conjugação dos verbos em -uar e alguns em -iar, bem como dos defectivos.

Este capítulo está organizado em cinco partes:

- 2.1 Generalidades, onde se exporá resumidamente o plano de cada uma das gramáticas, bem como se analisarão os critérios para a classificação dos verbos.

- $\quad$ 2.2 Conjugação dos verbos Regulares, auXiLiares, anômalos E irRegulares, onde será feita uma comparação entre a forma como os diferentes autores apresentam as formas flexionadas dos verbos assim classficados. 
- 2.3 Particularidades na conjugação de certos verbos, onde se mostrará como os autores tratam verbos que não são claramente declarados regulares ou irregulares.

- 2.4 Verbos defectivos, onde serão comparadas as listas de verbos defectivos propostas pelos autores das gramáticas voltadas para falantes de português como língua materna e as respectivas tábuas dos manuais de verbos, bem como será feita uma tentativa de identificação das razões para a defectividade verbal.

- $\quad 2.5$ CONSIDERAÇÕES FINAIS

É de interesse o Apêndice 1 - Plano de exposição da morfologia verbal nas obras EXAminadas no Capítulo 2, quando se quiser verificar o modo como cada assunto é tratado pelos autores.

Neste Capítulo, foram utilizados os símbolos fonéticos do IPA (2005), que nem sempre coincidem com os de Bechara (1999) e Cunha; Cintra (1985).

\subsection{Generalidades}

Primeiramente, será visto o modo como cada um dos autores insere a morfologia verbal em sua gramática. Em seguida, serão apresentados e discutidos os critérios por eles usados para expor a segmentação do verbo. Finalmente, será estabelecida relação entre a classificação proposta nessas obras e a proposta na NGB - Nomenclatura Gramatical Brasileira.

\subsubsection{INSERÇÃo DA MORFOLOGIA NAS OBRAS}

Algumas gramáticas voltadas para falantes de português como língua estrangeira têm objetivo exclusivamente didático. Além do tratamento teórico do tema, Abreu; Murteira (1998) e Masip (2000) trazem séries de exercícios com respostas. Dentro do mesmo espírito, Hutchinson; Lloyd (2002, p. XII) lançam mão de quadros e outros recursos gráficos para "oferecer ao aluno de português um panorama sucinto e razoavelmente abrangente da gramática portuguesa". ${ }^{26}$

Outras são destinadas "particularmente (mas não exclusivamente) ao público universitário" (Teyssier, 1984, p. 11) ou a "estudantes de todos os níveis, em particular aos de

\footnotetext{
${ }^{26}$ No original, "The aim of this work is to offer the student of Portuguese a succinct and reasonably comprehensive overview of Portuguese grammar."
} 
intermediário e avançado, e para uso de seus professores” (Perini, 2002, p. XxI). Embora este último autor declare que sua gramática apresente "uma descrição minuciosa da língua portuguesa, tanto falada quanto escrita" e aquele tenha feito uma boa descrição do "português contemporâneo", recorrendo a informações históricas apenas quando muito esclarecedoras do estado da língua moderna, ao menos no que toca à morfologia verbal, as duas obras não têm o fôlego da de Vázquez Cuesta; Mendes da Luz (1980) e da de Gärtner (1998a). ${ }^{27}$

As duas autoras ibéricas deixam claro que:

[...] dentro da maior simplicidade por se destinar não exclusivamente aos alunos de Filologia Românica das nossas Faculdades de Filosofia e Letras mas ao público em geral, procurámos oferecer nesta Gramática, juntamente com a descrição da língua literária e familiar de Portugal e do Brasil, um panorama completo, embora elementar, do passado do idioma e do seu estado actual nas regiões e entre os sectores da população onde não triunfou a norma lingüística da comunidade culta. [...] (Vázquez Cuesta; Mendes da Luz, 1980, p. 12)

O romanista alemão é autor de uma gramática "com o fim de servir de obra de consulta para professores de português e para alunos avançados, para os quais era geralmente difícil o acesso a obras recentes de Lingüística portuguesa e mesmo a textos em língua portuguesa" (Gärtner, 1998b, p. 1).

Essas duas últimas gramáticas equiparam-se à “Moderna Gramática Portuguesa, que "alia a preocupação de uma científica descrição sincrônica a uma visão sadia da gramática normativa, libertada do ranço do antigo magister dixit e sem baralhar os objetivos das duas disciplinas" (Bechara, 1999, p. 20), e à Gramática do português contemporâneo, cujos autores se preocuparam não só com "o ensino da língua portuguesa não só em Portugal, no Brasil e nas nações lusófonas da África, mas em todos os países em que se estuda a nossa língua", mas também com "a descrição do português contemporâneo que levasse em conta as diversas normas vigentes dentro do seu vasto domínio geográfico (principalmente as admitidas como padrão em Portugal e no Brasil)”. (Cunha; Cintra, 1985, p. XIII).

\footnotetext{
${ }^{27} 1^{\circ}$ ) No original de Teyssier (1984), "Parlé au Portugal, au Brésil et dans divers pays d'Afrique et d'Asie désormais souverains, le portugais occupe de vastes zones du globe. Il figure en bone position dans le groupe des langues á vocation internationale. Il est donc normal que l'étude du portugais attire un nombre de plus en plus grand de personnes. C'est à elles que s'adresse le présent ouvrage, et tout particulièrement (mais non exclusivement au public universitaire.". $2^{\circ}$ ) No original de (Perini, 2002), "This grammar presents a detailed description of the modern Portuguese language as spoken and written in Brazil. It is intended for the use of English-speaking students at all levels, in particular intermediate and advanced ones, and for the use of their teachers.
} 
A maioria dos autores apresenta a morfologia antes da sintaxe do verbo, seja no mesmo capítulo (Bechara, 1999; 1975; Cunha; Cintra, 1985; Teyssier, 1984), seja em capítulos diferentes (Gärtner, 1998a; Perini, 2002; Vázquez Cuesta; Mendes da Luz, 1980). Nas restantes (Abreu; Murteira, 1998; Hutchinson; Lloyd, 2002; Masip, 2000), a morfologia é apresentada paralelamente ao uso de modos e tempos.

Nem sempre o número de páginas dedicadas ao verbo em cada uma das gramáticas é indicador de profundidade no tratamento do tema. No entanto, chama atenção o fato de que, enquanto a maioria dos autores faz sua exposição entre cinqüenta e sessenta páginas, Hutchinson; Lloyd (2002) e Masip (2000) o fazem em menos de trinta, e Abreu; Murteira (1998), em noventa.

Examinando-se, também, a quantidade de títulos e subtítulos, é possível perceber o nível de comprometimento, de cada um dos autores, com a clareza e a economia na organização da informação: Nas 27 páginas em que Hutchinson; Lloyd (2002), p.ex., tratam da morfologia verbal, há 76 títulos e subtítulos enquanto, nas 91 de Abreu; Murteira (1998) há 53.

O destaque excessivo às particularidades obscurece a visão geral, tão importante para a apreensão da informação - coisa de que não prescindem Cunha; Cintra (1985), Teyssier (1984) e Vázquez Cuesta; Mendes da Luz (1980), que organizam o conteúdo em grandes blocos encabeçados por doze títulos em média. ${ }^{28}$

\subsubsection{SegmentaÇão das fOrmas Verbais}

Ao tratar segmentação das formas verbais, a maioria dos autores das gramáticas usa terminação com o sentido de "segmento final de uma palavra" ou, como faz Gärtner, 1998a, no sentido de "sufixo". Mantém-se, aqui, a terminologia de cada um deles, sendo o uso de terminação e sufixo discutido no Capítulo 3, item 3.1.1.

Ao tratar da estrutura do verbo, Cunha; Cintra (1985, p. 376) reconhecem um "RADICAL VERBAL" e

uma TERMINAÇ̃̃o, da qual participa pelo menos um dos seguintes elementos:

a) a vogal TEMÁTICA - $a$-, característica dos verbos da $1^{a}$ conjugação:

canto cant-a-va cant-a-ra

\footnotetext{
${ }^{28}$ Para o plano das gramáticas voltadas para estrangeiros e para brasileiros, Cf. Apêndice 1, itens 1.1.1 e 1.1.2, respectivamente.
} 
b) o SUFIXO TEMPORAL (OU MODO-TEMPORAL), que indica o tempo e o modo:

cant-a-va cant-a-ra

c) a DESINÊNCIA PESSOAL (ou NÚMERO PESSOAL), que identifica a pessoa e o número:

canto cant-a-va-s cant-á-ra-mos

Com a supressão de canto, no item $b$, e a substituição de cantava por cantavas, no item $c$, os gramáticos deixam claro por que falam em "pelo menos um". Como se viu no Capítulo 1, itens 1.3.2 e 1.3.3, tanto o SMT quanto o SNP (aqui chamados "sufixo temporal" e "desinência pessoal") podem ser representados pelo morfema zero.

Bechara $(1999$, p. 233) reproduz a fórmula vista no Capítulo 1, item 1.1.3, chamando o sufixo de desinência (“" ( ou seja, um sufixo referente à flexão em vez de referente à derivação, que é sufixo derivacional ou lexical" (Câmara Jr., 1968, verbete sufixo). É o único autor a reproduzir e comentar a análise mórfica do padrão geral dos verbos em português, vista no Capítulo 1 , item 1.1.3.

Gärtner (1998a, p. 52) distingue a vogal temática (-a-,-e- ou - $i-)$ da desinência do infinitivo $(-r)$ dos verbos chamar, ofender e iludir, mas não destaca os constituintes da terminação nas outras formas verbais. Ao segmentar cantávamos em radical (cant) e terminação (ávamos), Teyssier (1984, p. 153) aglutina a vogal temática (á) com o sufixo "temporal" ( $v a)$ e a desinência "pessoal" (mos).

Esse expediente é usado também por Hutchinson; Lloyd (2002) e Masip (2000) na conjugação dos verbos regulares, quando destacam graficamente a terminação, sem discriminar, contudo, a vogal temática e os sufixos modo-temporais e número-pessoais - o que só será didático no caso dos verbos regulares.

Perini (2002, p. 133-4) chega a propor um quadro com as terminações de primeira pessoa do singular e das formas nominais, reproduzido no Quadro 2.1.

\section{Quadro 2.1 - Reprodução da Table 11. Tense endings (First Person singular where APPLICABLE)}




\begin{tabular}{|c|c|c|c|c|}
\hline \multirow{6}{*}{ Indicative } & Present & $-O$ & $-O$ & $-O$ \\
\hline & Imperfect & $-a v a$ & $-i a$ & $-i a$ \\
\hline & [Future & -arei & -erei & -irei] + \\
\hline & Conditional & -aria & -eria & -iria + \\
\hline & Preterite & $-e i$ & $-i$ & $-i$ \\
\hline & [Pluperfect & -ara & -era & $-i r a]+$ \\
\hline \multirow{2}{*}{ Imperative } & (colloquial) & $-a$ & $-e$ & $-e$ \\
\hline & (formal) & $-e$ & $-a$ & $-a$ \\
\hline \multirow{3}{*}{ Subjunctive } & Present & $-e$ & $-a$ & $-a$ \\
\hline & Imperfect & -asse & -esse & $-i s s e+$ \\
\hline & Future & $-a r$ & $-e r$ & $-i r+$ \\
\hline \multirow{4}{*}{ Nominal forms } & $\begin{array}{l}\text { Impersonal } \\
\text { infinitive }\end{array}$ & $-a r$ & $-e r$ & $-i r+$ \\
\hline & $\begin{array}{l}\text { [Personal } \\
\text { infinitive }\end{array}$ & $-a r$ & $-e r$ & $-i r]+$ \\
\hline & Gerund & -ando & -endo & -indo + \\
\hline & Participle & $-a d o$ & $-e d o$ & $-i d o$ \\
\hline
\end{tabular}

De acordo com o autor, os colchetes assinalam os tempos que "atualmente, de um modo geral, se restringem à língua escrita" e o sinal + indica que "a diferença entre as conjugações consiste meramente na presença, no início do sufixo, de $a$, e, ou $i$, para a primeira, segunda e terceira conjugações". ${ }^{29}$

Por considerar essas terminações indevidamente como "sufixos", o autor reduz as vogais temáticas de primeira, segunda e terceira conjugações a meras letras iniciais em -aria, -eria e -iria, p.ex., ignorando a presença do único e real sufixo -ria. É preciso notar, ainda, que as terminações do "imperativo coloquial" (na verdade, presente do indicativo usado como imperativo) nem mesmo comportam um sufixo, pois o $-a$, na primeira conjugação, e o $-e$, na segunda e terceira conjugações (sendo nesta última o /e/ variante de /i/ em posição átona), são vogais temáticas, e é zero o sufixo modo-temporal, bem como o número-pessoal.

No entanto, em nenhum desses autores há equívocos graves, como os que se verificam em Masip (2000): é possível admitir que -o, p.ex., seja terminação em "tenho", mas não que -ns o seja terminação em "tens", tal como o autor apresenta.

Tanto Vázquez Cuesta; Mendes da Luz (1980) quanto Abreu; Murteira (1998) conjugam os verbos regulares sem destaque para nenhum dos morfemas.

\footnotetext{
${ }^{29}$ No original, "Tenses within brackets, [ ], are nowadays largely restricted to the written language. [...] Tenses marked with + are those in which the difference between the conjugations consists merely of the presence, at the beginning of the suffix, of $a, e$ e $i$, for the first, second and third conjugations, respectively, e.g.,. -asse, -esse, -isse."
} 


\subsubsection{Regularidade, IRREgUlaRidade E OUTRAS ClassificaÇões PARA OS VERBos}

Como nos textos oficiais da NGB - reproduzidos por Kury (1959, p. 1-34) e Oliveira (1965, p.175-98) - não há nenhum comentário à mera lista de termos a serem usados nas análises fonética, morfológica e sintática, os gramáticos brasileiros definem, cada um à sua maneira, o que seja verbo regular, irregular, anômalo, defectivo, abundante, auxiliar.

Esta última classificação nada tem a ver com a morfologia do verbo, mas com a sintaxe, por participar da "conjugação perifrástica" (Kury, 1959, p. 65), emprestando muitas vezes também "um matiz semântico ao verbo principal e dando origem aos chamados aspectos do verbo." (Bechara, 1999, p. 230).

Desconsiderando, assim, a classificação dos verbos como auxiliares (embora conjuguem os verbos ter, haver ser e estar na seção "Verbos auxiliares e o seu emprego"), bem como a distinção entre verbos irregulares e anômalos (que não se estabelece na Nomenclatura Gramatical Portuguesa), Cunha; Cintra (1985, p. 374) classificam o verbo em quatro categorias:

Os Regulares flexionam-se de acordo com o paradigma, modelo que representa o tipo comum da conjugação [...].

São IRREGULARES os verbos que se afastam do paradigma de sua conjugação [...].

Verbos DEFECTIVos são aqueles que não têm certas formas [...] Entre os DEFECTIVOS costumam os gramáticos incluir os UNIPESSOAIS, especialmente os IMPESSOAIS, usados apenas na $3^{\text {a }}$ pessoa do singular [...].

ABundanTES são os verbos que possuem duas ou mais formas equivalentes. De regra, essa abundância ocorre no particípio.

Bechara (1999, p. 227) porém, dá como exemplos de verbos abundantes aqueles que apresentam duplicidade também em formas conjugadas: "havemos e hemos; constrói e construi". O mesmo fazem os autores das gramáticas explicativas da NGB (Kury, 1959, Luft, 1978 e Oliveira, 1965). Bechara (1999, p. 226) explicita, ainda, a diferença entre verbos defectivos (aos quais "quase sempre faltam as formas rizotônicas”), impessoais e unipessoais.

Diferentemente de Cunha; Cintra (1985), Bechara (1999, p. 226) adota o rótulo anômalo para o verbo "que apresenta, na sua conjugação, radicais primários diferentes: ser (reúne o concurso de dois radicais, os verbos latinos sedēre e ĕsse") e ir (reúne o concurso de três radicais, os verbos latinos ire, vadēre e ĕsse)", observando que "outros autores consideram anômalo o verbo cujo radical sofre alterações que o não podem enquadrar em 
classificação alguma: dar, estar, ter, haver, ser, poder, ir, vir, ver, caber, dizer, saber, pôr, etc.".

É neste último sentido que Perini (2002) conjuga oito "verbos anômalos" (anomalous verbs): dar, estar, haver, ir, pôr, ser, ter e vir. Em obras explicativas da mesma NGB, Kury (1959, p. 63) elenca ser, ir, pôr, ter, haver, estar, ver e vir; Luft (1978, p. 95), os mesmos verbos, declarando, porém, ser "melhor reservar o termo 'anômalo' para os verbos ir e ser, por causa da heteronímia de seus radicais".

Mencionando apenas estes dois últimos verbos, Oliveira (1965, p. 75) discute a classificação:

\begin{abstract}
Uma vez que os verbos "anômalos" são verbos particularmente "irregulares" é discutível, à luz dos princípios de simplificação que norteiam a "NGB", a utilidade do termo "anômalo", como lembra Isaac Nicolau Salum (artigo in "O Estado de São Paulo", edição de 21/6/1959): "Consagra (a Nomenclatura) a distinção entre 'irregular' e 'anômalo', na classificação dos verbos, distinção dispensável, para quem quer simplificar $[\ldots]$
\end{abstract}

Luft (1978, p. 95) também advoga o uso de uma só classificação, mas não em nome da simplificação ou da inclusão de uma categoria (verbo anômalo) dentro da outra (verbo irregular). Trata-se, antes, de uma questão terminológica:

Observa Marouzeau (LTL, s. v. Irrégulier) que hoje se tende a substituir o termo
"irregular" por "anômalo", porque aquele se presta a equívocos e impropriedades
devidos a conceitos errôneos de "regra" ("a irregularidade resulta em geral da
aplicação de regras não percebidas", id. ib.) O irregular é produto de regras de
menor abrangência. Seria, pois, preferível o termo único "anômalo", oposto a
"normal". Entretanto a denominação opositiva regular/irregular é arraigada demais
para se pensar numa alteração terminológica.

O mais relevante na posição de Marouzeau (1943, verbete irrégulier) é a observação de que são "irregulares as formas ou construções que não estão inteiramente de acordo com um tipo considerado como normal" e de que "a irregularidade resulta em geral da aplicação de regras não percebidas", conforme se viu no Capítulo 1, item 1.2.

Isso vai ao encontro da posição de Câmara Jr. (1972, 1970), que está reproduzida em (Bechara,1999, p. 225-6) de que irregular é o verbo que, "em algumas formas, apresenta variação no radical ou na flexão". Não há dúvida de que essa definição é mais adequada do que aquela segundo a qual o verbo irregular "se afasta do respectivo paradigma, apresentando flexões não consideradas modelares na respectiva conjugação” (Luft, 1978, p. 94), ou ainda 
"não se pauta exatamente pelo paradigma de sua conjugação" (Kury, 1959, p. 63), na mesma linha do que fazem Cunha; Cintra (1985).

Vázquez Cuesta; Mendes da Luz (1980, p. 438-9) advertem que:

[...] a maior parte das irregularidades que se observam nos verbos portugueses se radicam nos perfeitos simples, que levam o acento no radical em vez de na terminação e derivam directamente dos perfeitos fortes latinos. Noutras ocasiões, a irregularidade que afecta a primeira pessoa do singular do presente do indicativo passa a todo o presente do conjuntivo, tempos intimamente ligado com ele. [...]

É por isso que as autoras distinguem a conjugação dos "verbos irregulares" e "outros tipos especiais de conjugação", dentre os quais a alternância vocálica, fenômeno ao qual Bechara (1999; 1975), Cunha; Cintra (1985), Gärtner (1998a) e Teyssier (1984) também dão especial destaque. Verbos com outras particularidades nem sempre são tratados da mesma forma em cada uma das gramáticas, conforme será visto neste Capítulo, item 2.3.

\subsection{CONJUGaÇÃo dos VERBos REgUlares, AUXILIARES, ANÔMALOS E IRREGULARES}

Primeiramente, será examinada a forma como cada um dos autores apresenta os verbos regulares, com seus respectivos verbos-modelo, passando-se, então, aos verbos auxiliares, anômalos e irregulares.

\subsubsection{Verbos REgULARES}

Cunha; Cintra (1985, p. 377) organizam os verbos regulares em três grupos: o dos derivados do presente do indicativo, o dos derivados do perfeito do indicativo e o dos derivados do infinitivo. Essa divisão baseia-se no pressuposto de que o verbo em português "apresenta três tempos primitivos, sendo os outros deles derivados", mais especificamente a primeira pessoa do presente do indicativo; a segunda pessoa do singular do pretérito perfeito e o infinitivo não flexionado, ou uma forma do pretérito imperfeito, conforme se viu no Capítulo 1, item 1.1.3.

Apesar de os autores ressaltarem a importância desse "artifício didático" tomado ao latim, o "processo formativo" não vem à luz, pois ilustram a exposição com cantar, vender e partir, sem variação no radical, nos quais as marcas das formas ditas primitivas não são notadas nas ditas derivadas. 
Todos os autores fazem figurar a conjugação completa dos verbos regulares nos tempos simples, ainda que nem sempre os nomeiem regulares, como Hutchinson; Lloyd (2002, p. 56), que graficamente destacam sua conjugação, como reproduzido no Quadro 2.2.

\section{QuAdro 2.2 - REProduÇão do QUAdro de CONJUGaÇÃo doS VERbos REGULARES NO PRESENTE do indicativo de Hutchinson; Lloyd}

\begin{tabular}{|c|c|c|c|c|}
\hline $\begin{array}{l}\text { eu } \\
\text { tu } \\
\text { ele, ela, você } \\
\text { nós } \\
\text { (vós) } \\
\text { eles, elas, vocês }\end{array}$ & $\begin{array}{l}\text { cantar } \\
\text { 'to sing' } \\
\text { canto } \\
\text { cantas } \\
\text { cant } a \\
\text { cantamo } \\
S \\
\text { cantais } \\
\text { cantam }\end{array}$ & $\begin{array}{l}\text { vender } \\
\text { 'to sell } \\
\text { vendo } \\
\text { vendes } \\
\text { vende } \\
\text { vendemos } \\
\text { vendeis } \\
\text { vendem }\end{array}$ & \begin{tabular}{l}
\multicolumn{1}{l}{ partir } \\
'to leave' \\
parto \\
partes \\
parte \\
partimos \\
partis \\
partem
\end{tabular} & $\begin{array}{l}\quad \text { pôr } \\
\text { 'to put' } \\
\text { ponho } \\
\text { pões } \\
\text { põe } \\
\text { pomos } \\
\text { pondes } \\
\text { põem }\end{array}$ \\
\hline
\end{tabular}

É preciso dizer que o verbo pôr não é modelo de uma quarta conjugação - não nomeada, mas sugerida pela sua inclusão no quadro de verbos tradicionalmente usados como modelos de verbos regulares. Conforme se viu no Capítulo 1, item 1.3.1, pôr apresenta a vogal temática característica da segunda conjugação.

Gärtner (1998a) e Vázquez Cuesta; Mendes da Luz (1980) conjugam também os compostos, como o fazem Bechara (1999; 1975) e Cunha; Cintra (1985). Em algumas gramáticas, constam também outras tábuas de conjugação: na voz passiva, com pronome reflexivo e com pronome átono não-reflexivo $(o)$.

Abreu; Murteira (1998) apresentam essas três tábuas em todos os tempos simples e também nos compostos. O mesmo fazem Bechara (1999; 1975) e Gärtner (1998a), mas apenas para a conjugação pronominal reflexiva, no caso do primeiro, e para a conjugação passiva, no caso do segundo.

No Quadro 2.3, estão discriminados os tipos de conjugação completa encontrada em cada uma das gramáticas, com indicação dos verbos-modelo escolhidos por cada um dos autores. 
Quadro 2.3 - ConjugaÇão dos verbos Regulares nos tempos simples, na voz Passiva, PRONOMINAL NAS GRAMÁTICAS

\begin{tabular}{|l|c|c|c|c|c|c|}
\hline \multirow{2}{*}{ gramáticas } & \multicolumn{7}{|c|}{ conjugação } \\
\cline { 2 - 8 } & \multicolumn{2}{|c|}{ dos verbos regulares } & $\begin{array}{c}\text { na voz } \\
\text { passiva }\end{array}$ & $\begin{array}{c}\text { com pronome } \\
\text { reflexivo }\end{array}$ & $\begin{array}{c}\text { com pronome } \\
\text { átono } o\end{array}$ \\
\hline Abreu; Murteira & amar & atender & partir & louvar & lavar-se & tirar \\
\hline Bechara & cantar & vender & partir & amar & apiedar-se & pôr \\
\hline Cunha; Cintra & cantar & vender & partir & louvar & lavar-se & \\
\hline Gärtner & chamar & ofender & iludir & os 3 anteriores & & os 3 anteriores \\
\hline Hutchinson; Lloyd & cantar & vender & partir & & & \\
\hline Masip & cantar & beber & partir & & lavar-se & \\
\hline Teyssier & cantar & vender & garantir & & & \\
\hline Perini & andar & vender & partir & & & \\
\hline Vázquez C.; Mendes L. & cantar & viver & unir & louvar & queixar-se & levar \\
\hline
\end{tabular}

Não é de se estranhar que a conjugação com pronome átono $o$ tenha sido proposta por apenas três autores. De fato, as modificações ortográficas em presença do pronome enclítico (e suas flexões) nas formas verbais em nasal (tiram-no, põe-no, p.ex.), -r (tirá-lo, p.ex.), -s (levamo-lo, p.ex) - e também da mesóclise nos dois futuros do indicativo - não justificam a conjugação de todas as formas verbais.

Basta a explicitação das regras, que Teyssier $(1984$, p. 88,155$)$ faz no capítulo do pronome pessoal ("Place des pronoms pesonnels atones"), e retoma no capítulo do verbo (“Les verbes et les pronoms pesonnels atones"), até porque o problema não diz respeito à morfologia verbal, mas a adaptações ortográficas.

Mesmo a conjugação passiva pode ser dispensada, pois consiste em perífrase do auxiliar ser conjugado (e também estar, dentre outros verbos de ligação) e de verbo principal no particípio. No que toca à morfologia, basta que se conheça a conjugação do verbo ser; o apassivamento é matéria da sintaxe.

Com relação à escolha dos verbos-modelo, nota-se, ainda no Quadro 2.3, a preferência pelos verbos cantar, para a primeira conjugação, e partir, para a terceira (em seis gramáticas), e de vender, para a segunda conjugação (em cinco). São esses os verbos escolhidos por Cunha; Cintra (1985), cujas obras figuram na bibliografia de todos os outros gramáticos. ${ }^{30}$

\footnotetext{
${ }^{30}$ A Nova gramática do português contemporâneo (aqui identificada como Cunha; Cintra, 1985) consta na bibliografia de Abreu; Murteira (1998), Gärtner (1998a), Hutchinson; Lloyd (2002), Masip (2000) e Perini (2002). Masip (2000) refere também a gramática de Evanildo Bechara, assim como Ryan (1991), que usou a Gramática do português contemporâneo, de Celso Cunha, editada pela Bernardo Álvares, que serviu de base para Cunha; Cintra (1985). Essa mesma edição consta na bibliografia de Vázquez Cuesta; Mendes da Luz (1980), Gärtner (1998a), Teyssier (1984).
} 
É curioso, por isso, que Vázquez Cuesta; Mendes da Luz (1980, p. 408-9) generalizem a afirmação relativa à escolha dos verbos-modelo nas "gramáticas dirigidas a portugueses ou brasileiros", sem nenhuma ressalva em favor do gramático brasileiro, cuja Gramática do português contemporâneo consta de sua "bibliografia fundamental".

\begin{abstract}
As gramáticas dirigidas a portugueses ou a brasileiros limitam-se, ao escolher seus paradigmas verbais regulares, à simples regularidade ortográfica, o que, a um estrangeiro, pode induzir em erro. Daí que tenhamos substituído neste livro os tradicionais amar, dever e partir de quase todas elas por verbos cuja vogal temática é um $i$ ou um $u$-vogais de timbre médio que carecem de realizações aberta ou fechadas com valor fonológico e que em posição átona conservam o seu timbre - ou uma nasal - a qual mantém o seu carácter fechado e cheio tanto quando é tónica como quando é átona -; são eles: cantar, viver e unir.
\end{abstract}

De toda forma, a observação das autoras serve para Masip (2000), que escolhe beber, com alternância vocálica nas duas variedades do português, e para Abreu; Murteira (1998) e Gärtner (1998a), que usam, respectivamente, como verbos-modelo da primeira conjugação amar e chamar - com variações de timbre no português europeu "sempre que o acento recai na terminação" (Vázquez Cuesta; Mendes da Luz; 1980, p. 409). ${ }^{31}$

É curioso que haja tanta variedade para os verbos-modelo: além dos já comentados amar, chamar e beber, encontram-se ainda os verbos atender em Abreu; Murteira (1998); ofender e iludir, em Gärtner (1998a); garantir em Teyssier (1984); andar em Perini (2002), e viver e unir em Vázquez Cuesta; Mendes da Luz (1980).

No caso de Gärtner (1998a), é possível arriscar uma razão: chamar, ofender e iludir prestam-se também às conjugações passiva e pronominal. Ainda em seu favor, note-se que, enquanto outros autores lançaram mão de quatro (Masip, 2000), cinco (Cunha; Cintra; 1985) e até seis verbos (Abreu; Murteira, 1998; Bechara, 1999; 1975 e Vázquez Cuesta; Mendes da Luz, 1980) para suas tábuas de conjugação, o lingüista alemão usou sempre os mesmos três verbos.

\title{
2.2.2 VERBOS AUXILIARES E ANÔMALOS
}

Cunha; Cintra (1985) apresentam a conjugação dos auxiliares ser, estar, ter e haver, fora da lista dos irregulares, sem atribuir-lhes nenhum rótulo, mas não há dúvida de que são tidos como irregulares, como deixa claro Bechara $(1999$; 1975), que, apesar de dar destaque à conjugação dos quatro verbos, os inclui entre os "irregulares". Teyssier (1984) faz o mesmo

\footnotetext{
${ }^{31}$ Como Gärtner (1998a) descreve, com muita propriedade, chamar entre os verbos com alternância vocálica de primeira conjugação, a escolha do verbo-modelo deve ser resultado de lapso na edição.
} 
com relação a ter e haver, conjugando ser e estar entre os verbos muito irregulares ("verbes très irréguliers").

Em Gärtner (1998a), e Perini (2002) são conjugados nas formas em que fogem ao paradigma dos verbos regulares, sendo classificados, pelo primeiro, entre os verbos irregulares (“Unregelmässige Verben”) e, pelo segundo, entre os anômalos (“anomalous"). Hutchinson; Lloyd (2002) conjugam-nos na lista dos verbos com presente irregular (“Irregular Present"), pretérito perfeito irregular (“Irregular Imperfect"), e assim sucessivamente. ${ }^{32}$

Na mesma linha, Abreu; Murteira (1998) incluem os auxiliares entre os verbos que têm o presente irregular ("verbi che hanno il presente irregolare"), verbos que têm o imperfeito irregular ("verbi che hanno il imperfetto irregolare"), etc., mas conjugam em anexo os principais verbos irregulares e o verbo haver. Além de tratar do uso pessoal e impessoal deste último verbo, observam que, "como auxiliar, tem o mesmo uso de ter, mas é usado na língua culta sobretudo escrita. Ocorre praticamente apenas no imperfeito do indicativo, condicional e imperfeito do conjuntivo". ${ }^{33}$

Os quatro verbos são conjugados como auxiliares, sem nenhuma outra classificação, em Masip (2000) e três deles (haver, ser e ter) em Vázquez Cuesta; Mendes da Luz (1980), que deixam estar na lista dos irregulares, talvez pelo fato de que, diferentemente de ser, o verbo em questão participa apenas secundariamente como auxiliar na construção perifrástica de voz passiva.

Apesar de a NGB propor a classificação dos verbos em auxiliar (de natureza sintática) ao lado das outras cinco (de natureza morfológica, mesmo no caso da já discutida classificação em anômalos), nas gramáticas explicativas da nomenclatura, os verbos auxiliares recebem, eventualmente, mais de uma classificação, conforme se pode ver no Quadro 2.4.

\footnotetext{
${ }^{32}$ Provavelmente por lapso na edição, as autoras não indicam nenhum verbo irregular no futuro do subjuntivo e só ser é conjugado no mais-que-perfeito do subjuntivo.

${ }^{33} \mathbf{1}^{\mathbf{}}$ ) No original, "Haver, como ausiliare, ha lo stesso uso de ter, ma è usado nel linguaggio accurato sopratutto scritto. Ocorre praticamente soltanto all'imperfetto dell'indicativo, condizionale ed imperfetto del congiuntivo.". $\left.\mathbf{2}^{\mathbf{0}}\right) \mathrm{Na}$ tradução, manteve-se a nomenclatura portuguesa (condicional e conjuntivo), usada pelas autoras em outros momentos, para o nosso futuro do pretérito do indicativo e futuro do subjuntivo.
} 
QUAdro 2.4 - ClassificaÇão de ESTAR, HAVER, SER E ter NAS GRAMÁticas EXPLICATIVAS da NGB

\begin{tabular}{|c|c|c|c|}
\hline verbos & Kury (1959) & Luft (1978) & Oliveira (1965) \\
\hline estar & auxiliar, irregular, e anômalo & auxiliar e irregular & auxiliar e irregular \\
\hline haver & auxiliar e anômalo & auxiliar & auxiliar \\
\hline ser & auxiliar e anômalo & auxiliar e anômalo & anômalo \\
\hline ter & auxiliar e anômalo & auxiliar & auxiliar \\
\hline
\end{tabular}

Desconsiderando-se a classificação em anômalo, como o fazem declaradamente Cunha; Cintra (1985), os verbos auxiliares não passam de verbos irregulares, que não deixam de ter uma regularidade interna, especialmente no padrão especial para o grupo do perfeito, conforme visto no Capítulo 2, itens 1.4.2.

\subsubsection{VERBOS IRREGULARES}

Os verbos irregulares são apresentados em listas onde figuram os tempos em que há formas que fogem ao paradigma dos verbos regulares, apresentados:

- de acordo com a conjugação a que pertencem, obedecendo à ordem alfabética, nas seções “Conjugação dos verbos irregulares” (Bechara, 1999, p. 267-75); “Outros tipos de irregularidade" (Cunha; Cintra, 1985, p. 409-29), "Verbos irregulares" (Vázquez Cuesta; Mendes da Luz (1980, p. 438-48);

- em ordem alfabética, no apêndice "Conjugação dos principais verbos irregulares" (Coniugazione dei principali verbi irregolari) (Abreu; Murteira, 1998, p. 210-5) e na seção "Verbos irregulares" (Unregelmässige Verben) (Gärtner, 1998a, p. 76-7);

- de acordo com os tempos e modos em que há formas que fogem ao paradigma dos regulares, ao longo do capítulo (Hutchinson; Lloyd, 2002, p. 57-73; Masip, 2000, p. 115-20; Teyssier, 1984, p. 172-85), sendo que este último autor acrescenta uma "Lista dos verbos muito irregulares" (Liste des verbes très irréguliers), e

- $\quad$ sem critério aparente, no apêndice "Verbos irregulares e anômalos" (Irregular and Anomalous Verbs) (Perini (2002, p. 585-96)

A primeira modalidade de apresentação (de acordo com a conjugação a que pertencem, obedecendo à ordem alfabética) é de fácil consulta e faz lembrar que cada um das três conjugações tem um paradigma particular. Em Cunha; Cintra (1985, p. 413), os quadros (apenas com os tempos em que há formas que fogem ao paradigma dos regulares) permitem 
identificar melhor a irregularidade, conforme se vê na reprodução do quadro de conjugação dos verbos crer e ler, no Quadro 2.5

\section{Quadro 2.5 - Reprodução do quadro de conjugaÇão dos verbos CRer e ler de Cunha; Cintra} (1985)

\section{Crer e ler}

São irregulares no PRESENTE DO INDICATIVO e, em decorrência, no PRESENTE DO SUBJUNTIVO e nos IMPERATIVOS AFIRMATIVO E NEGATIVO.

\begin{tabular}{|c|c|c|c|}
\hline \multirow{2}{*}{$\begin{array}{c}\text { Indicativo } \\
\text { presente }\end{array}$} & \multirow{2}{*}{$\begin{array}{l}\text { Subjuntivo } \\
\text { presente }\end{array}$} & \multicolumn{2}{|c|}{ Imperativo } \\
\hline & & AFIRMATIVO & Negativo \\
\hline $\begin{array}{l}\text { creio } \\
\text { crês } \\
\text { crê } \\
\text { cremos } \\
\text { credes } \\
\text { crêem }\end{array}$ & $\begin{array}{l}\text { creia } \\
\text { creias } \\
\text { creia } \\
\text { creiamos } \\
\text { creiais } \\
\text { creiam }\end{array}$ & $\begin{array}{l}\text { crê } \\
\text { creia } \\
\text { creiamos } \\
\text { crede } \\
\text { creiam }\end{array}$ & $\begin{array}{l}\text { não creias } \\
\text { não creia } \\
\text { não creiamos } \\
\text { não creiais } \\
\text { não creiam }\end{array}$ \\
\hline leio & leia & & \\
\hline lês & leias & lê & não leias \\
\hline lê & leia & leia & não leia \\
\hline lemos & leiamos & leiamos & não leiamos \\
\hline ledes & leiais & lede & não leiais \\
\hline lêem & leiam & leiam & não leiam \\
\hline
\end{tabular}

A título de comparação, veja-se a conjugação do verbo crer em Bechara (1999, p. 267), onde faltam, provavelmente por lapso na edição, três formas do imperativo afirmativo e todas as do imperativo negativo:

\section{Crer}

Pres. ind.: creio, crês, crê, cremos, credes, crêem

Pret. perf.. ind.: cri, creste, creu, cremos, crestes, creram

Pres. subj.: creia, creias, creia, creiamos, creiais, creiam

Pret. imp. subj.: cresse, cresses, cresse, crêssemos, crêsseis, cressem

Fut. subj.: crer, creres, crer, crermos, crerdes, crerem

Imp.: crê, crede

Part: : crido

A segunda modalidade (em ordem alfabética, sem discriminação da conjugação) assemelha-se à dos manuais de conjugação verbal. A penúltima (de acordo com os tempos e modos em que há formas que fogem ao paradigma dos regulares) é didática, mas pouco econômica, pois repetem-se os mesmos verbos em todos os tempos em que são dados como irregulares.

É preciso fazer uma ressalva para o caso de Gärtner (1998a), cuja lista de verbos em ordem alfabética é uma retomada do assunto tratado adequadamente como mudança da 
consoante no final do radical ("Veränderung des stammauslautendem Konsonanten") e particularidades do radical do perfeito ("Besonderheiten der Perfekstammes"), vistos no Capítulo 1, itens 1.4.1.2 e 1.4.2.

A última (sem critério aparente), em que os verbos não vêm agrupados por conjugação, nem em ordem alfabética, nem expostos didaticamente por grupos de irregularidade, dificulta enormemente a consulta.

Se a lista de Cunha; Cintra (1985) tem apresentação melhor do que a das demais, do ponto de vista do conteúdo é também a mais equilibrada, pois os gramáticos não incluem aí os verbos tratados nas seções anteriores ("Verbos auxiliares" e "Verbos com alternância vocálica"), tampouco nas posteriores ("Verbos de particípio irregular", "Verbos abundantes e "Verbos impessoais, unipessoais e defectivos").

Uma parte dos verbos irregulares elencados pelos gramáticos - dar; dizer, fazer, pôr, querer, saber, trazer e ver; ouvir, vir - consta também da lista dos outros. Os restantes, todos com variação no radical, estão incluídos na lista dos irregulares de Bechara $(1999 ; 1975)$ e Teyssier (1984), mas nem sempre nas outras gramáticas, conforme se pode ver no Quadro 2.6.

QUADRo 2.6 - VERBOS NEM SEMPRE MENCIONADOS COMO IRREGULARES NAS GRAMÁTICAS

\begin{tabular}{|c|c|c|c|c|c|c|}
\hline verbos & Gärtner & $\begin{array}{l}\text { Vázquez C.; } \\
\text { Mendes L. }\end{array}$ & $\begin{array}{l}\text { Abreu; } \\
\text { Murteira }\end{array}$ & Perini & Masip & $\begin{array}{c}\text { Hutchinson; } \\
\text { Lloyd } \\
\end{array}$ \\
\hline aprazer & $\mathrm{x}$ & & & & & \\
\hline caber & $\mathrm{x}$ & $\mathrm{x}$ & $\mathrm{x}$ & $\mathrm{x}$ & $\mathrm{x}$ & \\
\hline ler & $\mathrm{x}$ & $\mathrm{x}$ & $\mathrm{x}$ & $\mathrm{x}$ & $\mathrm{x}$ & \\
\hline crer & $\mathrm{x}$ & $\mathrm{x}$ & $\mathrm{x}$ & $\mathrm{x}$ & & \\
\hline \multicolumn{7}{|l|}{ desprazer } \\
\hline medir & $\mathrm{x}$ & $\mathrm{x}$ & $\mathrm{x}$ & $\mathrm{x}$ & & $\mathrm{x}$ \\
\hline pedir & $\mathrm{x}$ & $\mathrm{x}$ & $\mathrm{x}$ & $\mathrm{x}$ & & $\mathrm{x}$ \\
\hline perder & $\mathrm{x}$ & $\mathrm{X}$ & $\mathrm{x}$ & $\mathrm{x}$ & & \\
\hline poder & $\mathrm{x}$ & $\mathrm{x}$ & $\mathrm{x}$ & $\mathrm{x}$ & $\mathrm{x}$ & \\
\hline \multicolumn{7}{|l|}{ prazer } \\
\hline requerer & $\mathrm{x}$ & $\mathrm{x}$ & & & & \\
\hline rir & $\mathrm{x}$ & $\mathrm{x}$ & $\mathrm{x}$ & $\mathrm{x}$ & $\mathrm{x}$ & \\
\hline valer & $\mathrm{x}$ & $\mathrm{x}$ & $\mathrm{x}$ & $\mathrm{x}$ & & \\
\hline $\begin{array}{l}\text { verbos em } \\
\text {-ear e -iar }\end{array}$ & & & $\mathrm{x}$ & $\mathrm{x}$ & & \\
\hline
\end{tabular}

A ausência do pouco usado prazer não é relevante em Gärtner (1998a) - que, ainda assim, registra aprazer - e emVázquez Cuesta; Mendes da Luz (1980). Também não tem 
relevância a omissão de requerer em Abreu; Murteira (1998) e Perini (2002). As maiores lacunas estão principalmente em Hutchinson; Lloyd (2002) e, secundariamente, em Masip (2000).

Este último autor peca não só por omissão: na seção das "irregularidades dos pretéritos", há verbos absolutamente regulares nesse tempo (andar, conduzir, morrer e rir), sem falar nas "irregularidades dos imperativos", onde conjuga verbos que seguem o modelo do imperativo nos verbos regulares (reproduzindo duas formas do presente do indicativo, sem o $s$, e três do presente do subjuntivo): dizer, fazer, fugir, ir, pedir, pôr, sair, seguir, ter, trazer e vir.

Finalmente, são também Cunha; Cintra (1985, p. 429) os únicos autores que reservam uma lista especial para oito verbos com particípio irregular, que montam a onze, se incluídos

[...] três verbos da $1^{\text {a }}$ conjugação - ganhar, gastar e pagar - de que outrora se usavam normalmente os dois particípios. Na linguagem atual preferem-se, tanto nas construções com o auxiliar ser como naquelas em que entra o auxiliar ter, as formas irregulares ganho, gasto e pago, sendo que a última substituiu completamente o antigo pagado.

Além desses verbos, listam também 27 "verbos abundantes" (dez na primeira conjugação; oito na segunda e nove na terceira), com particípio irregular ao lado do irregular, conforme se vê no Quadro 2.7.

\section{Quadro 2.7 - Verbos com Particípio irregular em Cunha; Cintra (1985)}

\begin{tabular}{|c|c|c|c|c|c|}
\hline \multicolumn{2}{|c|}{ 1 $^{\text {conjugação com particípio }}$} & \multicolumn{2}{|c|}{$2^{\text {a }}$ conjugação com particípio } & \multicolumn{2}{c|}{$3^{\text {a }}$ conjugação com particípio } \\
\hline irregular & irregular e regular & irregular & irregular e regular & irregular & irregular e regular \\
\hline \multirow{6}{*}{ ganhar } & aceitar & & & & emergir \\
& entregar & & acender & & exprimir \\
& enxugar & dizer & benzer & & extinguir \\
gastar & expressar & escrever & eleger & abrir & frigir \\
pagar & expulsar & fazer & incorrer & cobrir & imergir \\
& isentar & pôr & morrer & vir & imprimir \\
& matar & ver & romper & & inserir \\
& salvar & & suspender & & omitir \\
& soltar & & & submergir \\
& vagar & & & & \\
\hline
\end{tabular}

A esses 38 verbos com particípio irregular, Vázquez Cuesta; Mendes da Luz (1980) acrescentam outros 25 (absorver, afligir, agradecer, assentar, atender, cativar, cegar, completar, convencer, corrigir, cultivar, descalçar, dirigir, dissolver, distinguir, escurecer, inquietar, juntar, libertar, limpar, manifestar, nascer, ocultar, secar e tingir); Bechara 
(1999), dez (arrepender, desabrir, desenvolver, envolver, erigir, fartar, findar, pasmar, pegar, revolver); Gärtner, quatro (confundir, empregar, expelir e submeter); Teyssier (1984), um (incluir) e Abreu; Murteira (1998), um (omitir).

O registro de tantos particípios irregulares - alguns em desuso, como "repeso por arrepeso" (de arrepender), outros de caráter claramente adjetival, como culto (de cultivar) vai contra uma das tendências sugeridas por Cunha; Cintra (1985, p. 431):

\begin{abstract}
Muitos particípios irregulares, que outrora serviam para formar tempos compostos, caíram em desuso. Entre outros, estão nesse caso: cinto, do verbo cingir; colheito, do verbo colher; despeso, do verbo despender. Alguns, como absoluto (de absolver) e resoluto (de resolver) continuam na língua, mas com valor de adjetivos.
\end{abstract}

A outra tendência parece ser a da substituição do particípio regular pelo irregular (como no caso dos já citados ganho, gasto e pago) ou da criação popular de particípios irregulares: "Pelo modelo de entregue, formou-se empregue, de uso freqüente em Portugal e na linguagem popular do Brasil". 34

\title{
2.3 Particularidades na ConjugaÇão de Certos verbos
}

Primeiramente, será visto o tratamento dado aos verbos com discordância gráfica e aos verbos em -zer e -zir. Em seguida, será examinada a forma como os diferentes autores tratam questões importantes como a alternância vocálica, a ditongação dos verbos em -ear e -iar, a instabilidade na sílaba tônica dos verbos em -guar/-quar e -güir/-qüir. Finalmente, serão vistos outros casos isolados.

\subsubsection{DisCORDÂNCIA GRÁFICA}

Para a maioria dos autores, é regular a mudança ortográfica em certas formas dos verbos em -car, -çar, -gar, -cer, -ger, -car, -gir, -guer e -guir, considerando-se os termos utilizados por eles: discordância gráfica, (Cunha; Cintra, 1985); variação de grafia (Bechara, 1999; 1975), mudanças ortográficas (Vázquez Cuesta; Mendes da Luz, 1980), que também traduzem a orthographische Veränderung (Gärtner, 1998a), e adaptações ortográficas, que traduzem as adaptations orthographiques (Teyssier, 1984) e o orthographic adjustement (Perini, 2002).

\footnotetext{
${ }^{34}$ Essa tendência fica clara em exemplo extraído de blog da Internet: “ontem foi aniversário da minha mulher, aí eu fui aprontar uma surpresa / so que eu marco a surpresa, e chego na hora certa / e ninguem tinha chego, estragou tudo! / chegaram tudo com $20 \mathrm{~min}$ de atraso!” (http://ueba.com.br/forum/lofiversion, 14/10/2006, 20:00)
} 
Hutchinson; Lloyd (2002) observam em nota que essas mudanças se fazem "para preservar o som original da consoante radical”, sem reconhecer nenhuma irregularidade nelas. Só Abreu; Murteira (1998) falam em irregolarità grafica (irregularidades gráficas) e Masip (2000) inclui, na seção de "irregularidades dos presentes de indicativo e subjuntivo", aparecer, crescer e conhecer, que "mudam o $-c$ em -ç na primeira pessoa do singular do presente do indicativo".

Ambos os procedimentos são inadequados, pois "não entram no rol dos verbos irregulares aqueles que, para conservar a pronúncia, têm de sofrer variação de grafia" (Bechara, 1999, p. 226). Prevista também para formas nominais derivadas (saquinho, ao lado de saco, e corajoso, ao lado de coragem, p.ex.), a discordância gráfica incide sobre determinadas formas flexionadas do verbo: na primeira conjugação, primeira pessoa do pretérito perfeito do indicativo e todas do presente do subjuntivo e, na segunda e terceira, primeira pessoa do presente do indicativo e todas as do presente do subjuntivo.

No Quadro 2.8, a discordância gráfica está ilustrada nas três conjugações pelos verbos-modelo de Ryan (1991) - e Rodrigues (2003), no caso de ressarcir (que, naquela autora é considerado defectivo, sem as formas em que ao $c$ - se seguiria um -o ou $-a$ ).

\section{QuAdro 2.8 - EXEMPLOS DAS POSSIBILIDADES DE DISCORDÂNCIA GRÁFICA NO VERBo}

\begin{tabular}{|c|c|c|c|c|c|c|c|c|c|}
\hline & \multicolumn{3}{|c|}{$1^{\mathrm{a}}$ conjugação } & \multicolumn{3}{c|}{$2^{\mathrm{a}}$ conjugação } & \multicolumn{3}{c|}{$3^{\mathrm{a}}$ conjugação } \\
\cline { 2 - 10 } & infin. & $1^{\mathrm{a}}$ pret. perf. ind. & pres. subj. & infin. & $1^{\mathrm{a}}$ pres. ind. & pres. subj. & infin. & $1^{\mathrm{a}}$ pres. ind. & pres. subj. \\
\hline$c / q u$ & ficar & fiquei & fique & & & & & & \\
\hline$c / c$ & laçar & lacei & lace & tecer & teço & teça & $\begin{array}{c}\text { ressarci } \\
\text { r }\end{array}$ & ressarço & ressarça \\
\hline$g / g u$ & largar & liguei & ligue & & & & & & \\
\hline$g / j$ & & & & abranger & abranjo & abranja & reagir & reajo & reaja \\
\hline
\end{tabular}

\subsubsection{VERBOS EM -ZER E -ZIR}

Cunha; Cintra (1985) incluem também em sua lista de irregulares os verbos em -uzir, que a maioria dos outros autores examina em seções especiais, a saber:

- "Verbos terminados em -zer e -zir: tipos fazer e traduzir" (Bechara, 1999; 1975);

- "Verben mit stammauslautendem Vokal" (Verbos com radical terminado em vogal), (Gärtner, 1998a);

- “Verbes terminés en -zer et -zir" (Verbos terminados em -zer e -zir), (Teyssier, 1984), e 
- “Outros tipos especiais de conjugação” (Vázquez Cuesta; Mendes da Luz, 1980).

Hutchinson; Lloyd (2002) e Masip (2000) omitem-se a respeito dos verbos em -uzir, dando conta dos em -azer na conjugação de fazer, prazer e trazer (de jazer só Bechara, 1999; 1975 e Gärtner, 1998a tratam - como irregular, e não como defectivo) e dos em -izer, na conjugação de dizer, conforme se viu neste Capítulo, item 2.3.2.

Abreu; Murteira (1998) e Perini (2002) consideram, respectivamente, conduzir e produzir como irregulares, que servem de modelo para um número insignificante de outros verbos: induzir, luzir reluzir, na gramática publicada na Itália e conduzir e reproduzir, na gramática publicada nos Estados Unidos. Aqui também não há nenhuma razão para que conduzir, p.ex., seja modelo numa gramática e faça parte da lista dos que seguem o modelo de produzir, na outra.

\subsubsection{AlternânCIA VOCÁliCA}

Considerando beber verbo regular da primeira conjugação, Abreu; Murteira (1998) e Masip (2000) não distinguem as "diferenças de timbre na vogal do radical conforme nele recaia ou não o acento tônico", que "não são exatamente as mesmas na variante européia e na variante brasileira da língua portuguesa, devido sobretudo ao fenômeno da redução das vogais em sílaba átona" (Cunha; Cintra, 1985, p. 402).

$\mathrm{Na} \mathrm{NGB}$, não se faz menção à alternância vocálica, da qual se ocupam estes últimos autores, Bechara (1999; 1975), e também Perini (2002), particularmente na variante brasileira. Dão igual destaque à variante européia Gärtner (1998a); Teyssier (1984);Vázquez Cuesta; Mendes da Luz (1980).

Hutchinson; Lloyd (1992, p. 80) mencionam marginalmente a mudança de som na vogal na conjugação verbal (“changing vowel sounds in verbal conjugation”), exemplificando-a insuficientemente, com apenas um verbo de cada uma das três conjugações (lavar, dever e dormir), fazendo uma nota para os verbos da terceira conjugação: "Nos verbos em -ir, a vogal radical $e$ ou $o$ transforma-se em $i$ ou $u$ respectivamente na primeira pessoa do singular" (p. 56). ${ }^{35}$

\footnotetext{
${ }^{35}$ No original, "If the stem vowel in -ir verbs is an $\mathbf{e}$ or $\mathbf{0}$, it becomes i or u respectively in the first person of plural."
} 
De todos os gramáticos, Cunha; Cintra (1985, p. 403-4) são os que mais pormenorizam os casos de alternância. Apresentam dois verbos ilustrativos da primeira conjugação (levar e lograr), descrevendo, à maneira de regra geral, que:

[...] no primeiro, à vogal fechada [ə] do português normal de Portugal e à semifechada [e] do português normal do Brasil, que aparecem na $1^{\mathrm{a}}$ e $2^{\mathrm{a}}$ pessoas do plural, corresponde a semi-aberta $[\varepsilon]$ na $1^{\mathrm{a}}, 2^{\mathrm{a}}$ e $3^{\mathrm{a}}$ pessoas do singular e na $3^{\mathrm{a}}$ do plural. No segundo, há uma mutação semelhante: à vogal fechada $[\mathrm{u}]$ do português normal de Portugal e à semifechada [o] do português normal do Brasil, existentes nas formas arrizotônicas, corresponde à semi-aberta $[\square]$ nas formas arrizotônicas.

Fazem, então, uma série de "observações", que em sua maioria podem ser interpretadas como verdadeiras exceções para os verbos:

- $\quad$ em que as vogais $e$ e $o$ fazem parte de ditongo, vêm seguidas de consoante nasal articulada ou são nasais;

- em que a vogal $e$ vem seguida de consoante palatal (mas os verbos invejar, embrechar, frechar e vexar conjugam-se como levar), e

- chegar (e derivados) e em -oar.

Para a segunda, Cunha; Cintra (1985, p. 405) conjugam outros dois verbos-modelo (dever e mover) e, novamente à maneira de regra geral, mostram que:

a) no PRESENTE DO INDICATIVO, as formas rizotônicas apresentam uma alternância da vogal semifechada [e] e [o] da $1^{\text {a }}$ pessoa do singular com a vogal semi-aberta $[\varepsilon]$ e [] da $2^{\text {a }}$ e $3^{\text {a }}$ pessoas do singular e da $3^{\text {a }}$ do plural; nas formas arrizotônicas observase a distinção entre as vogais átonas fechadas $[ə]$ e $[u]$ do português de Portugal e as semifechadas [e] e [o] do português do Brasil;

b) no PRESENTE DO SUBJUNTIVO, o português do Brasil mantém em todas as formas a vogal [e] ou [o], conservada no português de Portugal somente nas formas rizotônicas, pois nas arrizotônicas se dá a redução normal a [ə] ou [u].

c) no IMPERATIVO AFIRMATIVO, a $2^{\mathrm{a}}$ pessoa do singular, em correspondência com a do PRESENTE Do INDICATIVO, tem a vogal semi-aberta [e] ou []; no português do Brasil, a $2^{\mathrm{a}}$ pessoa do plural, forma arrizotônica, e as formas derivadas do PRESENTE Do SUBJUNTIVo ( $3^{\text {a }}$ do singular, $1^{\text {a }}$ e $3^{\text {a }}$ do plural e todas as pessoas do IMPERATIVO NEGATIVO) conservam a voga] semifechada [e] ou [o] deste tempo; no português de Portugal, as formas rizotônicas derivadas do PRESENTE DO SUBJUNTIVO mantêm a vogal semifechada [e] ou [u], mas as formas arrizotônicas apresentam a redução a [ə] ou [u].

Aqui também, excetuam-se os verbos:

- em que as vogais $e$ e $o$ vêm seguidas de consoante nasal articulada ou são nasais; 
- querer e poder, que apresentam todas as formas rizotônicas do presente do indicativo com $e$ semi-aberto, além de irregularidade nos tempos derivados do presente do indicativo no caso do primeiro (queira, queiras, etc.)

Em relação à terceira, conjugam primeiramente dois modelos (servir e dormir), para os quais formulam uma espécie de regra geral:

a) no PRESENTE DO INDICATIVO, as formas rizotônicas apresentam uma alternância da vogal fechada [] ou [0] da $1^{\text {a }}$ pessoa do singular com a vogal semi-aberta [0] e [0] [ə] da $2^{\mathrm{a}}$ e $3^{\mathrm{a}}$ pessoas do singular e da $3^{\mathrm{a}}$ do plural; nas formas arrizotônicas observase a redução vocálica normal a [ə] ou [0] no português europeu e uma oscilação entre $[0 /[]$ ou $[\square / \square]$ no português do Brasil, com predominância da vogal fechada $[0]$ ou [] por influência assimilatória da vogal tônica;

b) no PRESENTE DO SUBJUNTIVO, derivado da $1^{\text {a }}$ pessoa do PRESENTF DO INDICATIVO, mantém-se em todas as formas as vogais daquela pessoa, [] ou [0], conforme o caso;

c) no IMPERATIVO AFIRMATIVO, a $2^{\mathrm{a}}$ pessoa do singular, em correspondência com a do PRESENTE DO INDICATIVO, tem a vogal [0] ou [ $\mathrm{C}$ ]; a $2^{\mathrm{a}}$ do plural, em consonância com a do PRESENTE DO INDICATIVO, apresenta a vogal [ə] ou [0], no português de Portugal, e [0/0] ou [0/0], no português do Brasil; as formas derivadas do PRESENTE DO SUBJUNTIVo ( $3^{\text {a }}$ do singular, $\mathrm{l}^{\mathrm{a}}$ e $3^{\mathrm{a}}$ do plural e todas as pessoas do IMPERATIVO NEGATIVO) conservam a vogal [] ou [] deste tempo.

Fazem constar, então, nova série de observações, onde, além de conjugar um terceiro modelo (agredir), que apresenta "[i] nas quatro formas rizotônica do PRESENTE DO INDICATIVO,

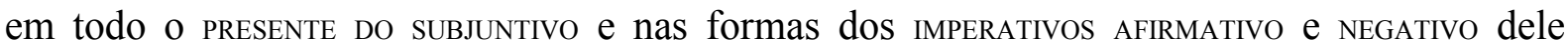
derivadas", apontam como exceções os verbos:

- em que a vogal $o$ faz parte de ditongo;

- medir, pedir, despedir e impedir, que apresentam vogal semi-aberta em todas as formas rizotônicas, e

- polir e sortir, "que apresentam vogal fechada em todas as formas rizotônicas, "aliás, de pouco uso".

Conjugam, ainda, mais dois modelos (frigir e acudir), para os quais formulam igualmente uma espécie de regra geral:

[...] embora tenham [i] e [u] no radical, os verbos frigir e acudir se comportam como se fossem verbos com $e$ e $o$ gráficos no infinitivo, conjugando-se nos quatro tempos mencionados pelos modelos de servir e dormir.

Seguem-se as exceções para os verbos: 
- aludir, assumir, curtir, iludir, presumir, resumir, urdir e os verbos em -uir (mas os verbos construir, destruir e reconstruir comportam-se como acudir);

- entupir e desentupir, construir, destruir e reconstruir podem apresentar também as formas sem alternância;

- aspergir e submergir, que têm e semifechado na $1^{\text {a }}$ pessoa do singular e nas formas dela derivadas.

Bechara (1999, p. 239-43) simplifica essas informações todas, propondo dois grupos de verbos com alternância vocálica na primeira conjugação (levando-se em conta apenas a variante brasileira), um para a segunda e oito para a terceira.

Na seção "Verbos notáveis quanto à pronúncia ou flexão", Bechara (1999, p. 245) enfatiza que, em roubar e inteirar, p.ex., os ditongos fechados ou e ei não se reduzem a vogais abertas: "roubo (e não róbo, etc.)" e "(inteiro (e não intéro, etc.)".

Desconsiderando a harmonização vocálica entre /e/-/i/, que simplifica a alternância na terceira conjugação, conforme se viu no Capítulo 1, item 1.4.1.2, a maioria dos autores identifica alternância entre vogais:

- $\quad$ semifechada e semi-aberta, na série das anteriores (/e/:/\&/) e posteriores (/o/:/】/), em verbos de primeira e segunda conjugações, e

- $\quad$ semifechada, semi-aberta e fechada, na série das anteriores $(/ \mathrm{e} /: / \varepsilon /: / 1 /)$ e posteriores (/o/:/[/:/u/), em verbos da terceira conjugação.

- $\quad$ semifechada e fechada, na série das anteriores (/e/:/i/) e posteriores (/o/:/u/), em verbos da terceira conjugação;

- fechada e semi-aberta, na série das anteriores $(/ \mathrm{i} / / / \mathcal{\varepsilon} /)$ e posteriores $(/ \mathrm{u} /: /[/ /)$, em verbos da terceira conjugação, e

- semifechada e semi-aberta, na série das anteriores (/e/:/\&/), em verbos da terceira conjugação, com dois subtipos.

Esses cinco tipos de alternância são ilustrados por verbos que nem sempre coincidem, conforme se pode ver no Quadro 2.9. Em boa parte dos casos, os verbos são conjugados em tábuas à moda de verbos-modelo; em outros casos, consta o primeiro verbo de uma lista de verbos ilustrativos, sem feição modelar. 


\section{QuAdro 2.9 - Verbos ILUSTRATIVOS Da ALTERNÂNCIA VOCÁLICA NO PORTUGUÊS Do BRASIL}

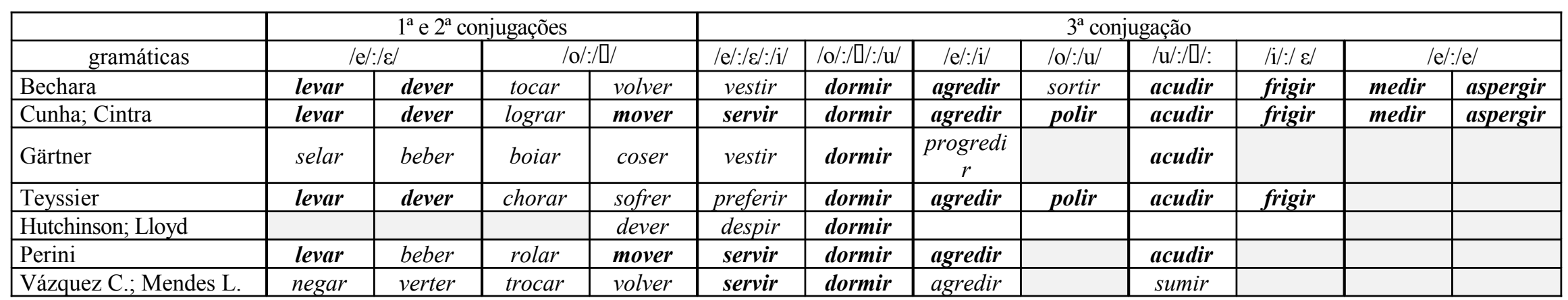

OBSERVAÇÕEs:

$1^{\circ}$ ) Gärtner (1998a) trata de outros tipos de alternância vocálica específicos da variante européia, passíveis de serem descritos também na variante brasileira

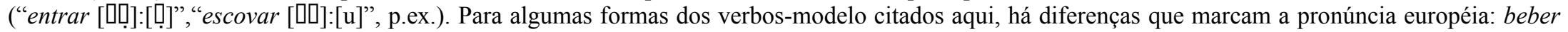
(bebemos [«], bebeis [«], bebamos [«] e bebais [«]), p.ex.

$2^{\circ}$ ) Teyssier (1984) identifica a variante brasileira, diferenciando-a da portuguesa; destaca o caso especial de reflectir, na variante portuguesa, (cujas formas arrizotônicas têm $e$ não-reduzido) e refletir, na variante brasileira (que se conjuga pelo modelo de preferir).

3.) Vázquez Cuesta; Mendes da Luz (1980), tratam também da alternância vocálica excepcional em domar, somar, tomar e ganhar, verbos em que a vogal é nasalizada por $m, n$ e $n h$ "não travantes". Na segunda conjugação, verter vem acompanhado de dever, e volver, de correr. Na terceira conjugação (p. 437-8), além de servir, lista ferir, sentir, mentir, reflectir, seguir, despir, aderir; além de dormir, cobrir; além de agredir, prevenir e progredir; além de sumir, fugir, acudir, bulir, consumir, cuspir, sacudir e engulir.

Os casos de alternância de primeira e segunda conjugações são ilustrados por todos os autores. Na terceira, apenas Cunha; Cintra

(1985) e Bechara $(1999$; 1975) dão exemplos de todos os casos. A omissão de verbos como polir e frigir, em Gärtner (1998a), Perini 
(2002) e Vázquez Cuesta; Mendes da Luz (1980) é compreensível, pela inexpressiva freqüência desse tipo de alternância, conforme se verá no Capítulo 3, item 3.3.3.1.

Seria também explicável a omissão de medir caso os autores tivessem observado a alternância entre vogal semifechada (/e/) em medir e semi-aberta (/\&/) em meço, mede, medes e medem, quando conjugam o verbo, ao lado de pedir, entre os irregulares. Aspergir, sem nenhuma outra particularidade que a alternância vocálica, o verbo deve ter sido mesmo negligenciado pela maioria dos autores.

É preciso notar que Vázquez Cuesta; Mendes da Luz (1980: 413 e 438) tratam dos verbos com alternância vocálica de terceira conjugação em duas seções ("Timbre da vogal temática tónica nos verbos da $2^{\text {a }}$ e da $3^{\text {a }}$ conjugação" e "Outros tipos especiais de conjugação"), muito provavelmente pelo fato de, na terceira conjugação, "este fenómeno, ao contrário do que sucede com a metafonia dos verbos da $2^{\mathrm{a}}$ conjugação, se reflectir na ortografia, determinando para este tipo de verbos a consideração gramatical de não-regulares”.

O mesmo fazem ver Cunha; Cintra (1985, p. 402), quando alertam para o fato de que não é lógico que, de um lado,

[...] se considerem regulares verbos como beber e mover [...] e, de outro lado, se tenham por irregulares verbos como frigir e acudir. Há flagrante semelhança nos casos citados. Apenas em beber e mover não se distinguem na escrita (fato meramente gráfico, por conseguinte), aquelas oposições de fonemas vocálicos a que nos referimos.

Essa diferença de tratamento fica clara quando, depois de ter dedicado espaço próprio à alternância vocálica (p. 239-43), Bechara (1999; 1975) inclui alguns dos verbos aí descritos (acudir, cobrir, frigir, mentir, progredir, servir e submergir) na lista dos verbos irregulares de terceira conjugação (p. 271-5), mas não segue o mesmo procedimento na lista dos irregulares das outras duas conjugações.

Isso sem falar dos autores que acabam por incluir na lista dos irregulares alguns dos verbos com alternância vocálica da terceira conjugação, discriminados no Quadro 2.10. 


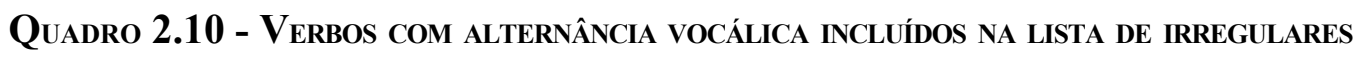

\begin{tabular}{|l|c|c|c|}
\hline \multicolumn{1}{|c|}{ verbos } & Masip & $\begin{array}{c}\text { Abreu; } \\
\text { Murteira }\end{array}$ & Bechara \\
\hline acudir & $\mathrm{x}$ & & $\mathrm{x}$ \\
\hline advertir & $\mathrm{x}$ & & \\
\hline cobrir & $\mathrm{x}$ & & $\mathrm{x}$ \\
\hline conseguir & $\mathrm{x}$ & & \\
\hline cuspir & $\mathrm{x}$ & & \\
\hline dormir & $\mathrm{x}$ & $\mathrm{x}$ & \\
\hline ferir & & $\mathrm{x}$ & \\
\hline frigir & $\mathrm{x}$ & & $\mathrm{x}$ \\
\hline mentir & & & $\mathrm{x}$ \\
\hline polir & & & $\mathrm{x}$ \\
\hline progredir & & $\mathrm{x}$ & \\
\hline seguir & & & \\
\hline sentir & & $\mathrm{x}$ & \\
\hline servir & $\mathrm{x}$ & $\mathrm{x}$ & \\
\hline sumir & $\mathrm{x}$ & & \\
\hline vestir & $\mathrm{x}$ & $\mathrm{x}$ & \\
\hline
\end{tabular}

O problema não está em considerar esses verbos irregulares, mas em fazer listas inexpressivas do ponto de vista quantitativo (há cerca de 200 verbos de terceira conjugação com alternância vocálica, como se verá no Capítulo 3, item 3.3.3.1), aparentemente sem critério de freqüência de uso na escolha dos verbos-modelo (por que advertir, e não divertir? por que progredir, e não agredir? por que acudir, e não sacudir?).

\subsubsection{VERBOS EM -EAR E -IAR}

Assim como Cunha; Cintra (1985, p. 410-1), outros autores fazem constar entre os irregulares "verbos em -ear e -iar". A diferença está no fato de que os dois autores tratam de passear como modelo de todos os verbos que "recebem um $i$ depois do e nas formas rizotônicas" e de incendiar como um dos cinco verbos que "mudam o [i] em [ej] nas formas rizotônicas", enquanto os outros autores não generalizam suficientemente seus modelos.

$\mathrm{Na}$ lista de Abreu; Murteira (1998), estão passear (como modelo apenas de atear, bloquear, estrear, lisonjear, recear e semear - sem mencionar que a lista é aberta) e odiar (como modelo de ansiar, incendiar, mediar e remediar - sem mencionar que a lista é fechada). Na de Perini (2002), aparece apenas odiar (como modelo de ansiar e incendiar). 
Gärtner (1998a) e Vázquez Cuesta; Mendes da Luz (1980) não se omitem com relação a esses dois grupos de verbos, dos quais tratam, respectivamente, na seção dos "verbos com radical terminado em vogal" (Verben mit stammauslautendem Vokal) e na seção "Outros tipos especiais de conjugação".

Hutchinson; Lloyd (2002) e Masip (2000) omitem-se com relação à ditongação nas formas rizotônicas de alguns verbos em -iar - que pode explicar-se, conforme se viu no Capítulo 1, item 1.4.1.1, pela mesma regra morfofonêmica aplicável aos verbos em -ear -, deixando de mostrar aos estrangeiros, como lembram Cunha; Cintra (1985, p. 411), que:

- cinco verbos em -iar (ansiar, incendiar, mediar, odiar e remediar), que "por analogia com os verbos em -ear (já que na pronúncia se fundem o $e$ e o $i$ reduzidos) [...] mudam o $[i]$ em $[e j]$ nas formas rizotônicas", e

- um grupo de verbos em -iar ("agenciar, comerciar, negociar, obsequiar, premiar e sentenciar, entre outros") que, "no português de Portugal e na língua popular do Brasil, não seguem uma norma fixa, antes vacilam entre os modelos de anunciar e incendiar".

Aos cinco verbos em -iar, poderia ser acrescentado intermediar, por ser derivado de mediar. No grupo do segundo item, Bechara (1999; 1975) inclui outros verbos (diligenciar, evidenciar, licenciar, penitenciar, presenciar, providenciar, reverenciar, vangloriar e vitoriar) “e outros", de modo que sua lista permanece aberta. Teyssier (1984) dá, também como exemplos, negociar, obsequiar, premiar e sentenciar, enquanto Vázquez Cuesta; Mendes da Luz (1980), apenas comerciar.

\subsubsection{VERBOS EM -GUAR/-QUAR E -GÜIR/-QÜIR}

Na seção "Verbos notáveis quanto à pronúncia ou flexão", Bechara $(1999 ; 1975)$ aborda o problema da fixação da sílaba tônica nas formas rizotônicas:

- dos verbos em -uar, de acordo com o modelo de aguar (águo, águas, etc; ágüe, ágües, etc.) ou apaziguar (apaziguo, apaziguas, etc; apazigúe, apazigúes, etc);

- $\quad$ de mobiliar (mobílio, mobílias, etc; mobílie, mobílies, etc.)

Enquanto o gramático registra a existência de uma variante mobilar, de conjugação regular, Cunha; Cintra (1985, p. 411) chamam atenção para a variante gráfica mobilhar, 
"admitida pelo Vocabulário Oficial e que melhor reproduz a sua pronúncia corrente”, eliminando a "anomalia mais gráfica do que fonética".

Masip (2000) forma um grupo de "alguns verbos em -iar e todos os "terminados em -quar e -guar", que se conjugam "com tonicidade especial nas três pessoas do singular e na terceira do plural do presente do indicativo e subjuntivo", listando abreviar, acariciar, aguar, copiar, afiliar, apaziguar e liquar.

Bechara (1999, p. 244) também chama atenção para a conjugação de obviar - "obvio (i), obvias ( $($ ) , obvia (i), obviamos, obviais, obviam (i)": conforme se viu acima, dentre os verbos em -iar que não apresentam variação na vogal radical (p.ex., odiar, com ditongação, e construir, com alternância vocálica), apenas mobiliar é passível de oscilação na tônica, ainda assim explicada por Cunha; Cintra (1985, p. 411) como "uma anomalia mais gráfica do que fonética".

No que toca aos verbos em -uar, não só estes dois últimos autores - que, como Vázquez Cuesta; Mendes da Luz (1980), tratam de adequar como verbo defectivo -, mas todos os outros omitem-se diante de um problema que atinge também outros verbos de terceira conjugação em que o $u$ faz parte dos grupos $g u$ e $q u$, dos quais Bechara $(1999 ; 1975)$ tampouco trata.

A questão não é simples porque, no uso, eventualmente a semivogal (ou semiconsoante) é tomada como vogal nos grupos -ua, -ue, -ui e -uo, antecedidos de $g$ - ou q-. Como observa Fernández (1951, p. 31),

Não é de se estranhar que diante dos ditongos crescentes a consciência auditiva creia estar na presença de sons consonânticos ou próximos deles. Por isso, a gramática tradicional só considerou como ditongos os decrescentes, influenciada sem dúvida pelo sistema vocálico do grego e do latim $[\ldots]^{36}$

No entanto, a recomendação dos autores de manuais de conjugação para as formas rizotônicas dos verbos em -guar, -quar, -güir e -qüir (sem o trema na grafia de Portugal) não é sempre a mesma, havendo verbos em que o $u$, tônico, é considerado vogal (V), em arguo, p.ex.; outros em que o $u$, átono, é considerado semivogal (SM), em águo, p.ex., conforme se pode ver no Quadro 2.11, onde há verbos dados como defectivos em todas as formas rizotônicas (D).

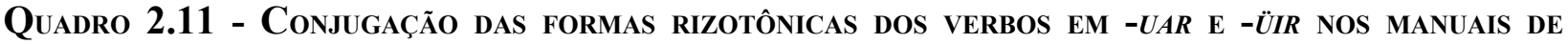 CONJUGAÇÃO VERBAL}

\begin{tabular}{|l|c|c|c|}
\hline verbos & Lopes & Rodrigues & Ryan \\
\hline
\end{tabular}

\footnotetext{
${ }^{36}$ No original, "No es extraño que ante los diptongos crecientes la conciencia auditiva crea hallarse en presencia de sonidos consonánticos o próximos a ellos. Por eso la gramática tradicional sólo ha considerado como diptongos a los decrecientes, influída sin duda por el sistema vocálico del griego y del latín [...]”.
} 


\begin{tabular}{|c|c|c|c|}
\hline adequar/readequar & D ou V & D ou SV & $\mathrm{D}$ \\
\hline aguar/anaguar/desaguar/enxaguar & $\mathrm{V}$ & SV ou V & SV \\
\hline alonginquar & & SV ou V & SV \\
\hline aminguar/minguar & SV & SV ou V & V ou SV \\
\hline antiquar & $\mathrm{V}$ & $\mathrm{D}$ & $\mathrm{D}$ \\
\hline apaniguar & $\mathrm{V}$ & $\mathrm{V}$ ou SV & SV \\
\hline apaziguar & V ou SV & V ou SV & SV \\
\hline apropinquar & V ou SV & SV ou V & SV \\
\hline argüir & $\mathbf{V}$ & $\mathbf{V}$ & $\mathbf{V}$ \\
\hline atreguar & $\mathrm{V}$ & V ou SV & SV \\
\hline averiguar & $\mathrm{V}$ & V ou SV & SV \\
\hline biguar & & $\mathrm{V}$ ou SV & SV \\
\hline coliquar & & V ou SV & \\
\hline contiguar & $\mathrm{V}$ & V ou SV & \\
\hline delinqüir & V ou SV ou D & SV & SV \\
\hline deslinguar & $\mathrm{V}$ & SV ou V & \\
\hline eguar & & V ou SV & \\
\hline fraguar & & SV ou V & SV \\
\hline obliquar & $\mathrm{V}$ & V ou SV & $\mathrm{V}$ \\
\hline redargüir & $\mathrm{V}$ & $\mathbf{V}$ & $\mathbf{V}$ \\
\hline retorqüir & $\mathrm{D}$ & SV & $\mathrm{D}$ \\
\hline santiguar & & V ou SV & \\
\hline
\end{tabular}

Note-se que, para Rodrigues (2003, p. 102-5), quase sempre o $u$ pode ser as duas coisas: preferentemente vogal (V ou SV) em dez casos e, preferentemente, semivogal em seis, segundo o que anota, respectivamente, nas tábuas de conjugação de:

- apaziguar/obliquar: "Há flutuação da localização da sílaba tônica destes verbos, sendo também aceita sua conjugação pelo padrão 5, de aguar", e

- aguar/anaguar/desaguar/enxaguar: "Há flutuação da tonicidade destes verbos, preferindo-se, em Portugal, sua conjugação pelo padrão 4, de apaziguar."

É curioso que Lopes (1992), cujo manual é publicado em Portugal, não dá as mesmas soluções para aguar e compostos, nos quais o $u$ é sempre vogal: águo, águas, etc.; ágüe, ágües, etc. Menos ainda Ryan (1990), que só admite dupla possibilidade para minguar (e, portanto, aminguar), que segue o paradigma de apaziguar, mas "admite também as formas do paradigma" de aguar.

A hesitação é flagrante: apenas no caso de argüir, concordam os autores de manuais de conjugação. Para aguar e derivados, a solução de Lopes (1992) nega a de Ryan (1990), enquanto 
Rodrigues (2003) aceita as duas soluções. Para delinqüir, o primeiro desses três autores registra três paradigmas, ou seja, cada falante que faça como melhor entender.

No Capítulo 3, item 3.3.3.2, será possível ver que Houaiss; Villar (2001a; 2001b) também hesitam com relação à "consciência auditiva” de que fala Fernández (1951).

\subsubsection{Outros casos}

Particularidades relativas estritamente à grafia ou pronúncia são contempladas apenas por:

- Gärtner (1998a), nas seções sobre a mudança da consoante final do radical e particularidades do radical do perfeito ("Veränderung des stammauslautendem Konsonanten e Besonderheiten des Perfektstamme"), já mencionadas neste Capítulo, item 2.2.3, e

- Bechara (1999), na seção "Verbos notáveis quanto à pronúncia ou flexão", já mencionada neste Capítulo, item 2.3.5.

Quando trata da mudança na tonicidade e acentuação gráfica, nos verbos com radical em hiato com acento gráfico nas formas em que a tônica no $i$ ou $u$ (s $\underline{a} \underline{u} d a r:$ saúdo; re $\underline{u}$ nir : reúno;

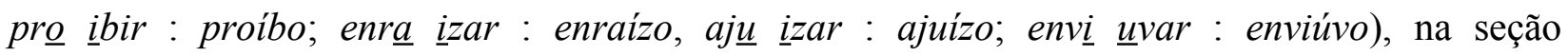
"Betonungswechsel und Akzentsetzung" (mudança na tonicidade e acentuação gráfica), Gärtner (1998a) faz ver que considera em todos esses verbos a existência de um hiato estável - o que impõe o acento gráfico nas formas rizotônicas.

É compreensível que a maioria dos outros autores não trate dessa particularidade gráfica, que atinge outras categorias gramaticais (saúde, raizes, juizo, viúvo, para citar alguns exemplos). Só Bechara (1999, p. 245) chama atenção para o fato de que "saudar proferido com ditongo (saudo, saudas, etc.) ocorre aqui e ali nos poetas e se fixa no falar coloquial e popular".

Para Aguiar (1955, p. 348), "não há dúvida de que, um dia, a conjugação será mesmo saudo, saudas, saudo. É questão de tempo. A ditongação do hiato não se efectuou ainda pela influência de saúde".

O acento gráfico no $i$ como vogal tônica de hiato (em caí, moí e distribui), bem como no $u$ tônico em formas dos verbos em "-guar e -guir" em que o $u$ é vogal (averiguar : averigúe e arguir : argúis) também têm respaldo nas regras de acentuação. $\mathrm{O}$ mesmo ocorre com a primeira vogal do hiato oo, que "apesar de terem a mesma pronúncia em todo o domínio do idioma, não 
são acentuadas no português de Portugal, ao passo que no português do Brasil recebem um acento circunflexo" (Cunha e Cintra, 1985, p. 71).

Bechara (1999, p. 244) conjuga o presente do indicativo de verbos com encontros consonantais como se nas formas rizotônicas houvesse oscilação na sílaba tônica - “rapto (rá), raptas (rá), rapta (rá), raptamos, raptais, raptam (rá)" -, quando não há aí senão a possibilidade de pronúncia inadequada, ainda que freqüente, da consoante muda.

Mais relevante é a observação esclarecedora a respeito da conjugação dos verbos:

- resfolegar (resfólego, resfólegas, etc; resfólegue, resfólegues, etc) ao lado de resfolgar (resfolgo, resfolgas, etc.);

- apiedar (apiedo, apiedas, apieda, apiedamos, apiedais, apiedam) ao lado de apiadar (apiado, apiadas, apiada, apiadamos, apiadais, apiadam), e

- moscar (mosco, moscas, mosca, moscamos, moscais, moscam) ao lado de muscar (musco, muscas, musca, muscamos, muscais, muscam).

Bechara (1999, p. 244) esclarece que:

A lição antiga de alguns gramáticos antigos e ortógrafos confundia o arcaico apiadar e apiedar numa só conjugação, o que não aconselhamos [...] A mesma confusão existia com moscar e muscar (sumir-se) [...] A correção, porém, talvez seja mais difícil, por serem muito pouco usados moscar e muscar.

O gramático reproduz o que diz Aguiar (1955, p. 348), que atribui aos eruditos "erros do tomo de resfólego, mobílio, mínguo, oblicúo, apiado (como flexão de apiedar), musco (como flexão de moscar) e outras aberrações". 


\subsection{VERBos DEFECTIVOS}

Primeiramente, será feita uma reflexão sobre o conceito de defectividade e as possíveis razões para a omissão de certas formas em determinados verbos. Em seguida, será examinada a classificação dos verbos defectivos nas gramáticas e manuais de conjugação. Finalmente, será feita uma tentativa de identificar as razões para a defectividade nos verbos examinados aqui.

\subsubsection{O CONCEITO DE DEFECTIVIDADE}

Antes de tratar dos verbos defectivos, Cunha; Cintra (1985 p. 431) lembram que, nos verbos impessoais (de uso restrito à $3^{\mathrm{a}}$ pessoa do singular) e unipessoais (de uso restrito à $3^{\mathrm{a}}$ pessoa do singular e do plural), "é a própria idéia expressa pelo verbo que não pode aplicar-se a determinadas pessoas".

Está claro que essa classificação não é morfológica, mas sintático-semântica, como observa Borba (1996: 65), quando trata dos verbos que indicam vozes de animais:

Têm comportamento sintático-semântico paralelo: todos são verbos de ação com um só argumento - o sujeito agente, nome de indivíduo do reino animal, capaz de produzir aquela voz; todos admitem o mesmo tipo de transferência para o traço humano (cf. cacarejar $\rightarrow$ soltar sua voz (a galinha); produzir (uma pessoa) som desagradável). [...]

A possibilidade de haver um sujeito agente com o verbo cacarejar, p.ex., está documentada em Borba (1990: verbete cacarejar): "E a velha de súbito cacarejou um riso frouxo (CBC); eu não cacarejo nem converso prosas de bicho de rabo (TR)". Embora, nas duas abonações, grunhir esteja na terceira pessoa do singular, é perfeitamente possível dizer grunhi (ou grunhiste, grunhimos, ou grunhistes) “com um ar de cansaço”, e o verbo já não poderá ser chamado de impessoal. ${ }^{37}$

\footnotetext{
37 Não havendo indicação da fonte no exemplo documentado no Dicionário Unesp do português contemporâneo, organizado pelo autor e publicado em 2004, mais recentemente, portanto ("Veja se fala direito, não fique aí cacarejando!"), deu-se preferência para o registro em dicionário publicado dois anos antes, onde o autor faz constar a indicação de que os dois exemplos foram, respectivamente, retirados de $O$ conto brasileiro contemporâneo. Bosi, A., org. São Paulo, Cultrix, 1977 e Travessias. Lopes, E., São Paulo, Moderna, 1980, segundo consta na lista de siglas do corpus de Borba (2002).
} 
Assim também, no verbete chover, o autor registra exemplos em que o verbo deixa de ser impessoal, como "Ninguém chove, ninguém faz sol (B)", em que ninguém pode ser substituído por qualquer um dos pronomes pessoais ou de tratamento. ${ }^{38}$

A defectividade dos "verbos que designam gritos de animais" já foi contestada por Said Ali (1931, p. 173), que argumentou com o uso na "linguagem das fábulas, em que imaginamos os animais falantes e, referindo-se a si próprios, usarão o verbo na $1^{\text {a }}$ pessoa" e, "em linguagem metafórica", em que se atribui ao "homem o que é próprio das criaturas irracionais".

Não há dúvida de que a defectividade está ligada ao uso. Fundamentado em diversos autores - alguns deles citados neste trabalho -, Santos (1989, p. 140) insiste nisso, argumentando, contudo, que as formas não flexionadas na "norma padrão" têm "lugar garantido dentro do vasto sistema do português, incapaz de lhes causar a menor rejeição, já que o sistema é eclético, imparcial e universal".

Isso equivale a dizer que, do ponto de vista morfológico, não há verbos defectivos posição assumida por Nogueira (1963, p. 8), em cujo seu manual aparece a conjugação completa de todos os verbos, pois o autor considera a defectividade um "critério injustificável e insubsistente", ainda que ponha "em itálico as formas que se diz faltarem".

Admitindo-se, com Cunha; Cintra (1985, p. 432), que uma determinada forma não se usa "por prestar-se a confusão com uma forma do outro verbo, de emprego mais freqüente" (a coincidência com as formas rizotônicas de falar justificaria a inexistência das respectivas formas em falir), a defectividade é determinada por razões morfológicas, mesmo que pouco prováveis.

No entanto, os gramáticos levantam outra hipótese para a defectividade verbal: a "pronúncia desagradável" de algumas formas (exemplificadas pelas rizotônicas de abolir). Implicando juízo e valor, "há freqüentes discordâncias entre os gramáticos em estabelecer os casos de lacuna verbal aconselhados por motivos eufônicos."

Said Ali (1931, p. 178) propõe, ao lado dessa razão, uma outra que não carece da subjetividade do julgamento de valor: a "dúvida relativa à aplicação da alternância vocálica [...] nos verbos defectivos em -ir, cuja lista, outrora bastante longa, o tempo se tem incumbido de ir reduzindo". E exemplifica com cinco verbos antes defectivos, conjugados com alternância vocálica: compelir (compilo), digerir (digiro), discernir (discirno), expelir (expilo), submergir (submirjo).

\footnotetext{
${ }^{38}$ O exemplo foi extraído de A borboleta amarela. Braga, R.. 4.ed. Rio de Janeiro, Sabiá, 1963, segundo
} consta na lista de siglas do corpus de Borba (2002). 
Lopes (1992, 5-6) também sugere que essas discordâncias possam ser decorrentes da alternância vocálica, quando comenta que a co-existência de formas como "acodes - aludes, pego - chego $([\varepsilon]-[\mathrm{e}])$ "

[...] dá lugar a padronizações mais relevantes, se não mesmo a formas opinativas de impossível confirmação prática, por divergentes ou contraditórias: do verbo colorir diz Sá Nogueira e M. Santos Alves que possui "conjugação completa"; Celso Cunha concede-lhe as formas em que se mantenha o $i$ ou em que este seja substituído por $e$; apenas lhe atribuem as formas em que se mantém o $i$ temático Francisco Torrinha, A. Gomes Ferreira e J. M. Nunes de Figueiredo, J. Pereira Tavares, F. J. Cardoso Júnior; F. Rebelo Gonçalves, no Vocabulário da Língua Portuguesa, faz preceder de um asterisco as formas em que não aparece o $i$, o que equivale a dizer que as considera teóricas; Camilo Castelo Branco e Cecília Meireles escreveram, respectivamente: “... maneiras que disfarçam e colorem as concessões", "O colar de Carolina/ colore o colo de cal/ torna colorada a menina". [...]

De todas elas, parece ser esta última a explicação mais aceitável, pois não é infreqüente o uso de formas de verbos defectivos com oscilação na abertura da vogal. ${ }^{39}$

\subsubsection{ClassificaÇão dos Verbos defECtivos nas gramáticas E Manuais de CONJUGaÇão}

Como se vê, as discordâncias entre os gramáticos na conjugação de colorir, assim como de outros verbos listados nas obras aqui examinadas, assentam-se na possibilidade de:

- conjugação completa, ainda que com formas teóricas,

- defectividade em uma forma rizotônica do presente do indicativo (primeira pessoa do singular), ou

- defectividade em quatro formas rizotônicas do presente do indicativo (primeira, segunda e terceira pessoas do singular e terceira do plural).

Nos dois últimos casos, faltam, por conseguinte, todas as formas do presente do subjuntivo e as respectivas do imperativo.

Com exceção de Abreu; Murteira (1998), Gärtner (1998a) e Masip (2000), que não tratam dos verbos defectivos, os autores das outras gramáticas abordam o tema, em profundidade (Bechara, 1999; 1975; Cunha; Cintra, 1985; Teyssier, 1984, e Vázquez Cuesta; Mendes da Luz, 1980), ou superficialmente (Hutchinson; Lloyd, 2002 e Perini, 2002).

\footnotetext{
${ }^{39}$ Sirvam de exemplo as duas formas do verbo explodir, em frases colhidas na Internet: "Quando sou atingido por um raio, eu expludo, espero dois segundos, eu apareço.", (//http:educação.cnotinfor.pt, 19/12/2006, 17:20), ao lado de "30 segundos para explodir...vejo algumas caras mais familiares...pedem para eu parar...digo que agora já não consigo...já não posso voltar atrás... / 10 segundos...os momentos mais marcantes da minha vida vão passando por mim...as memorias...as tristezas....as fraquezas...onde para a alegria? / Explodo! (www.escritacriativa.com, 19/12/2006, $17: 22)$.
} 
Este último registra apenas abolir e aturdir, como defectivos em uma forma rizotônica, verbos também listados - além de banir, colorir, demolir, emergir e imergir -com a mesma classificação por as autoras da gramática publicada na Inglaterra, que citam falir como verbo defectivo nas quatro formas rizotônicas.

Bechara (1999, p. 226-7) é quem propõe o maior número de verbos defectivos, dividindoos em três grupos - e não em dois, como fazem a maioria dos gramáticos:

a) os que não se conjugam nas pessoas em que depois do radical aparecem $a$ ou $o[\ldots]$

b) os que se usam unicamente nas formas em que depois do radical vem $i[\ldots]$

c) oferecem particularidades especiais: [...]

1 - precaver(-se) e reaver. No pres. ind. só têm as duas primeiras pessoas do plural [...]

2 - adequar, antiquar: cabem-lhe as mesmas observações feitas ao grupo anterior.

3 - grassar e rever (= destilar): só se usam nas terceiras pessoas.

$\mathrm{Na}$ verdade, precaver-se, reaver, adequar e antiquar comportam-se como os verbos listados no item b e só estão separados deles porque não fazem parte da terceira conjugação, à qual pertence a maioria dos verbos defectivos, como observam Cunha; Cintra (1985).

De fato, são unipessoais, e não defectivos, outros verbos dessas duas conjugações incluídos na lista de Bechara (1999; 1975), Vázquez Cuesta; Mendes da Luz (1980) e Teyssier (1984): grassar e rever, no sentido de "destilar", no autor brasileiro; precatar-se, nas autoras ibéricas, e soer, no autor francês.

Na primeira conjugação, as flexões de adequar e antiquar - defectivos nas quatro formas arrizotônicas para Bechara (1999; 1975), Cunha; Cintra (1985) e Ryan (1991), mas conjugados integralmente em Rodrigues (2003), com o $u$ pós-tônico - não pode ser dissociada da dos outros verbos em -guar e -quar, conforme se viu neste Capítulo, item 2.3.5.

Na segunda, Vázquez Cuesta; Mendes da Luz (1980, p. 415) argumentam que reaver não se conjuga nas formas rizotônicas pelo fato de o primitivo haver ser utilizado "raras vezes para a formação dos tempos compostos". Certamente, ao fazer essa afirmação, as autoras pensam no uso do presente de haver no pretérito perfeito composto do indicativo, já que, no uso culto, mesmo na língua falada, o auxiliar é bastante usado especialmente no pretérito mais-que-perfeito composto.

No caso de precaver-se, a defectividade nas mesmas formas parece vir da hesitação entre conjugar o verbo indevidamente como derivado de ver ou mesmo, inexplicavelmente, seguindo o modelo de $v i r .^{40}$

\footnotetext{
${ }^{40}$ Se assim não fosse, os professores não tratariam do tema, como documentado em site de dúvidas: Precaver-se também não se conjuga em todas as pessoas. Assim, não existem as formas "precavejo", "precavês", "precavém”, "precavenho", "precavenha”, “precaveja”, etc. (http://falabonito.wordpress.com, 15/02/2007, 21:55).
} 
Bechara $(1999,1975)$ dá ainda como defectivo, em uma forma rizotônica, o verbo feder, conjugado integralmente em Lopes (1992), Rodrigues (2003) e Ryan (1991). Esta última autora observa que "A primeira pessoa do singular do presente do indicativo e suas derivadas são usadas em linguagem popular." Isso mostra que - além da identidade formal com outros verbos, a falta de eufonia e a hesitação no timbre da vogal - há quem leve em conta uma quarta explicação para a defectividade, de ordem estritamente semântica: o preconceito lingüístico.

No Quadro 2.12, estão reproduzidos os verbos mencionados por pelo menos dois gramáticos, com a indicação de D1 para os defectivos em apenas em uma forma; D4, para os defectivos em quatro formas, e CC, para os de conjugação completa. 
Quadro 2.12 - Verbos defectivos Mencionados EM PELO MENOS dUAS GRAMÁticas

\begin{tabular}{|c|c|c|c|c|c|c|c|c|c|}
\hline verbos & Bechara & $\begin{array}{l}\text { Cunha; } \\
\text { Cintra }\end{array}$ & Teyssier & $\begin{array}{l}\text { Vásquez, C.; } \\
\text { Mendes L. }\end{array}$ & verbos & Bechara & $\begin{array}{l}\text { Cunha; } \\
\text { Cintra }\end{array}$ & Teyssier & $\begin{array}{l}\text { Vásquez, C.; } \\
\text { Mendes L. }\end{array}$ \\
\hline fremir & D1 & D1 & D1 & D1 & abolir & D1 & D1 & D1 & D4 \\
\hline fulgir & D1 & D1 & D1 & D1 & banir & D1 & D1 & D1 & D4 \\
\hline aturdir & D1 & D1 & D1 & & carpir & D1 & D1 & D1 & D4 \\
\hline brandir & D1 & D1 & D1 & & colorir & D1 & D1 & D1 & D4 \\
\hline exaurir & D1 & D1 & D1 & & delinqüir & D1 & D4 & D4 & \\
\hline jungir & D1 & D1 & D1 & & demolir & D1 & D1 & D1 & D4 \\
\hline haurir & D1 & D1 & & & extorquir & D1 & & & D4 \\
\hline ungir & & D1 & D1 & & puir & D1 & D4 & & \\
\hline comedir(-se) & D4 & D4 & D4 & D4 & retorquir & D1 & D1 & D1 & D4 \\
\hline remir & D4 & D4 & D4 & D4 & embair & $\mathrm{CC}$ & D4 & & D4 \\
\hline renhir & D4 & D4 & D4 & D4 & emergir & $\mathrm{CC}$ & D1 & D1 & D1 \\
\hline combalir & D4 & D4 & D4 & & \multirow{7}{*}{\multicolumn{5}{|c|}{$\begin{array}{l}\text { OBSERVAÇÃo: } \\
\text { A classificação de emergir serve para imergir e } \\
\text { submergir a a de comedir-se, para descomedir-se. }\end{array}$}} \\
\hline empedernir & D4 & D4 & $\mathrm{D} 4$ & & & & & & \\
\hline aguerrir & D4 & D4 & D4 & & & & & & \\
\hline falir & D4 & & D4 & D4 & & & & & \\
\hline fornir & D4 & D4 & & & & & & & \\
\hline adir & D4 & & & D4 & & & & & \\
\hline florir & D4 & & & D4 & & & & & \\
\hline
\end{tabular}

Na coluna da esquerda, há oito verbos defectivos em uma forma e dez, em quatro, nas gramáticas em que são mencionados, e muitas vezes nos manuais de verbos consultados. Lopes (1992), Rodrigues (2003) e Ryan (1991) concordam com a classificação de oito dos dez verbos defectivos em quatro formas (adir, aguerrir, empedernir, falir, florir, fornir, remir e renhir) e dois dos oito defectivos em uma forma (brandir e fremir).

De um lado, a discordância está na conjugação completa de aturdir, jungir e ungir (por Lopes, 1992 e Rodrigues, 2003) e de fulgir (por Rodrigues, 2003 e Ryan, 1991). De outro lado, está na classificação de combalir e comedir-se como defectivos em uma forma por Rodrigues (2003) e Ryan (1991); de exaurir como de conjugação completa por Rodrigues (2003) e defectivo em quatro formas por Ryan (1991), e de haurir como de conjugação completa, por Rodrigues (2003)

Os nove verbos da coluna da direita são classificados como defectivos ora em uma forma, ora em quatro, e a consulta aos manuais de verbos nem sempre resolve o problema.

Com relação a abolir, banir, carpir, colorir, demolir e retorquir, Ryan (1991) dá a mesma classificação da maioria dos autores: defectivos em uma forma. O mesmo faz Rodrigues (2003), mas levando em conta a alternância vocálica de abolir, colorir, demolir e retorquir - com /[/ nas três formas rizotônicas conjugadas. 
Para Lopes (1992) - que não observa a alternância vocálica -, abolir, colorir e demolir seguem o paradigma de combalir, com defectividade em quatro formas; os outros três verbos, em uma, com a ressalva de que "autores portugueses" consideram banir defectivo em quatro formas, assim como há "quem" classifique carpir e retorquir da mesma forma.

Com relação a extorquir, os três autores dão a mesma classificação de Bechara (1999; 1975) - defectivo em uma forma -, sendo que Rodrigues (2003) assinala a presença de /[/ nas três formas rizotônicas conjugadas.

Em Ryan (1991) e Rodrigues (2003), delinqüir recebe a mesma classificação indicada por Bechara (1999; 1975) - defectivo em uma forma - mas, em Lopes (1992), o verbo tem conjugação completa, pelo modelo de argüir (arguo, argúis, argúi, etc.).

Apenas Ryan (1991) concorda com Bechara $(1999 ; 1975)$ na defectividade de uma forma de puir; Lopes (1992) e Rodrigues (2003) dão a conjugação completa do verbo, pelo modelo de contribuir e ruir, respectivamente.

Para os dois verbos seguintes, Bechara $(1999 ; 1975)$ dá a conjugação completa. O mesmo fazem Rodrigues (2003) e Lopes (1992) para embair. Ryan (1991), assim como Cunha; Cintra (1985) e Vázquez Cuesta; Mendes da Luz (1980), considera o verbo defectivo nas quatro formas.

Bechara $(1999 ; 1975)$ não faz nenhuma referência à alternância vocálica de emergir, que atinge emerge, emerges e emergem - com a indicação de abertura no timbre da vogal em Cunha; Cintra (1985) e Teyssier (1984) - e que, no passado, teria atingido a quarta forma rizotônica, Rodrigues (2003) confirma emerjo (///) e emerge, emerges, emergem (///), mas Lopes (1992) preconiza emirjo, ao dar divergir como verbo-modelo para a conjugação de emergir, embora observe que "alguns autores" consideram o verbo defectivo em uma forma. 


\subsubsection{TeNTATIVA DE IDENTIFICAÇÃo DAS RAZÕES PARA A DEFECTIVIDADE VERBAL NOS VERbOS EXAMINADOS}

No Quadro 2.13, registra-se o número de ocorrência de classificação dos 29 verbos vistos acima como defectivos em uma forma (D1) ou em quatro (D4), de conjugação completa (CC) e com a indicação de sem menção (SM) autores, nas quatro gramáticas e nos três manuais de verbos.

\section{Quadro 2.13 - Número de autores Que Classificam os verbos do Quadro 2.12}

\begin{tabular}{|c|c|c|c|c|c|c|c|c|c|}
\hline verbos & D1 & $\mathrm{D} 4$ & $\mathrm{CC}$ & SM & verbos & D1 & $\mathrm{D} 4$ & $\mathrm{CC}$ & SM \\
\hline fremir & 7 & & & & fulgir & 5 & & 2 & \\
\hline banir & 6 & 1 & & & delinqüir & 3 & 2 & 1 & 1 \\
\hline brandir & 6 & & & 1 & aturdir & 4 & & 2 & 1 \\
\hline carpir & 6 & 1 & & & embair & & 4 & 2 & 1 \\
\hline retorquir & 6 & 1 & & & jungir & 4 & & 2 & 1 \\
\hline abolir & 5 & 2 & & & exaurir & 4 & 1 & 1 & 1 \\
\hline colorir & 5 & 2 & & & haurir & 4 & & 1 & 2 \\
\hline demolir & 5 & 2 & & & puir & 3 & 1 & 1 & 2 \\
\hline extorquir & 4 & 1 & & 2 & ungir & 3 & & 2 & 2 \\
\hline remir & & 7 & & & emergir & 3 & & 4 & \\
\hline renhir & & 7 & & & & & & & \\
\hline aguerrir & & 6 & & 1 & & & & & \\
\hline empedernir & & 6 & & 1 & & & & & \\
\hline falir & & 6 & & 1 & & & & & \\
\hline adir & & 5 & & 2 & & & & & \\
\hline comedir-se & 2 & 5 & & & & & & & \\
\hline florir & & 5 & & 2 & & & & & \\
\hline fornir & & 5 & & 2 & & & & & \\
\hline combalir & 2 & 4 & & 1 & & & & & \\
\hline
\end{tabular}

Levando-se em conta as sete obras consultadas, os verbos da coluna da esquerda são efetivamente defectivos - porque assim classificados por cinco dos autores, pelo menos, e também porque nenhum deles foi considerado de conjugação completa.

Isso posto, é possível comprovar em certos verbos a relação entre defectividade e alternância vocálica. Dos nove verbos classificados como defectivos em uma forma, cinco (abolir, colorir, demolir, extorquir e retorquir) seguem o modelo de dormir, apresentando alternância vocálica nas três formas rizotônicas conjugadas.

Se deixassem de ser defectivos, seriam conjugados *abulo, *coluro, *demulo, *exturco e * returco, a menos que seguissem o modelo da segunda conjugação, sendo então conjugados *abolo, *coloro, *demolo, *extorco e *retorco, seguindo o modelo de mover - o que não é absurdo como se verá adiante, quando se tratar de explodir e outros verbos mencionados por apenas um gramático. 
Dentre os verbos classificados como defectivos em quatro formas,, se conjugados, por mais estranho que soe ao ouvido, também apresentariam alternância vocálica:

- aguerrir e empedernir, pelo modelo de servir (*aguirro, *aguerres, *aguerre, *aguerrem; *empedirno, *empedernes, *empederne, *empedernem) ou de aspergir (*aguerro; *empederno), e

- florir e fornir, pelo modelo de dormir (*fluro, *flores, *flore, *florem; *furno, *fornes, *forne, *fornem), ou de mover, como se da segunda conjugação (*floro; ${ }^{*}$ forno $)$.

Na coluna da direita, todos os verbos são considerados por pelo menos um autor como de conjugação completa - o que põe em cheque a defectividade, independentemente do maior ou menor número de autores que admitem conjugação completa: quatro (emergir), três (embair), dois (aturdir, fulgir, jungir, puir e ungir) ou um (delinqüir, exaurir e haurir).

De qualquer forma, o que se observou na primeira coluna em relação à alternância vocálica, observa-se também aqui para emergir, que efetivamente apresenta hesitação entre dois modelos (de aspergir e frigir) para a primeira pessoa do singular, como observa Ryan (1991, $\mathrm{p}$. 154): "é comum substituir-se a primeira pessoa do singular do presente do indicativo, emirjo, que caiu em desuso, por emerjo e desta termos as derivadas". Aturdir e sobretudo puir - o qual Cunha; Cintra (1985) consideram defectivo em quatro formas - poderiam apresentar alternância vocálica em três formas rizotônicas, de acordo com o modelo de acudir e construir.

É também explicável a defectividade de delinqüir, considerada a hesitação - neste caso, sem relação com a alternância vocálica - entre duas formas possíveis (*delínquo a par de delinqúo) em função dos padrões de conjugação dos verbos em -guir e -quir, como se viu neste Capítulo, item 2.3.5.

Outros verbos, de ambas as colunas, se deixassem de ser defectivos na primeira pessoa do presente do indicativo, apresentariam formas coincidentes com as respectivas de verbos da primeira conjugação - uma das hipóteses de Cunha; Cintra (1985), igualmente mencionada acima, como causa da defectividade. São eles: carpir, comedir-se, falir e remir, em relação a começar, carpar, falar e remar.

Dos restantes, seis são de conjugação completa em pelo menos um manual:

- embair, conjugado por Lopes (1992) pelo modelo de subtrair; 
- exaurir e haurir, conjugados por Rodrigues (2003), pelo modelo de aplaudir, e

- fulgir, jungir, ungir, conjugados por Rodrigues (2003), pelo modelo de fingir e por Ryan (1991), pelo modelo de dirigir.

Seriam adir, banir, brandir, combalir, fremir e renhir defectivos pelas razões de ordem eufônica, de que falam também Cunha; Cintra (1985)?

Não se pode dar resposta a essa pergunta antes que se examine o comportamento de outros verbos defectivos, mencionados, dentre os gramáticos, apenas por:

- Cunha; Cintra (1985) - brunir, em uma forma, e foragir-se, em quatro formas;

- Teyssier (1984) - ungir, em uma forma, e punir (provavelmente no sentido de "pugnar", e não de "castigar"), em quatro formas;

- Vázquez Cuesta; Mendes da Luz (1980) - escapulir, gerir e munir, em quatro formas, e

- Bechara (1999; 1975) - delir, esculpir, espargir, explodir, impingir, pruir e ruir, em uma forma, e emolir, esbaforir, espavorir, exinanir, garrir, inanir, ressequir, revelir e transir, em quatro formas.

No Quadro 2.14, registra-se o número de autores (quatro das gramáticas e três, dos manuais de verbos) que classificam cada um desses verbos como defectivos em uma forma (D1) ou em quatro (D4), de conjugação completa (CC), com a indicação de sem menção (SM). ${ }^{41}$

\footnotetext{
${ }^{41}$ Além desses verbos, Bechara (1999, p. 227) identifica como "outrora defectivos, [...] hoje conjugados integralmente" advir, agir, compelir, desmedir-se, discernir, fruir, polir, prazer, refulgir, ressarcir e, como "defectivos", bramir e vagir, que são na verdade unipessoais.
} 


\section{QUADro 2.14 - NÚMERo de AUTORES QUE CLASSIFICAM OS VERBOS MENCIONADOS EM APENAS UMA GRAMÁTICA}

\begin{tabular}{|l|c|c|c|c|l|c|c|c|c|}
\hline verbos & D1 & D4 & CC & SM & verbos & D1 & D4 & CC & SM \\
\hline emolir & & $\mathbf{4}$ & & & escapulir & & 1 & $\mathbf{3}$ & \\
\hline espavorir & & $\mathbf{4}$ & & & gerir & & 1 & $\mathbf{3}$ & \\
\hline garrir & & $\mathbf{4}$ & & & espargir & 1 & & $\mathbf{3}$ & \\
\hline ressequir & & $\mathbf{4}$ & & & impingir & 1 & & $\mathbf{3}$ & \\
\hline inanir & $\mathbf{1}$ & $\mathbf{3}$ & & & munir & & 1 & $\mathbf{3}$ & \\
\hline delir & $\mathbf{2}$ & $\mathbf{2}$ & & & parir & & 1 & $\mathbf{3}$ & \\
\hline pruir & $\mathbf{3}$ & & 1 & & punir & & 1 & $\mathbf{3}$ & \\
\hline ruir & $\mathbf{3}$ & & 1 & & ressarcir & & 1 & $\mathbf{3}$ & \\
\hline exinanir & & $\mathbf{3}$ & & 1 & ungir & 1 & & $\mathbf{3}$ & \\
\hline esbaforir & & $\mathbf{3}$ & & 1 & brunir & 1 & 1 & 2 & \\
\hline foragir-se & & $\mathbf{3}$ & 1 & & desmedir-se & 1 & & 2 & \\
\hline revelir & & $\mathbf{3}$ & & 1 & esculpir & 1 & 1 & 2 & \\
\hline \multirow{2}{*}{} & & & explodir & 2 & & 2 & \\
\cline { 2 - 9 } & polir & & 2 & 2 & \\
\hline & & & & & 2 & 1 & 1 \\
\hline
\end{tabular}

Aqui também, a defectividade poderia ser explicada:

- pela possível alternância vocálica em delir, revelir e ressequir; emolir, esbaforir e espavorir; pruir e ruir, na coluna da esquerda, e gerir; escapulir, explodir e polir, na coluna da direita, e

- pela possível confusão com formas de verbos de emprego mais freqüente em parir (em relação a parar) e transir (em relação a transar), na coluna da direita.

No caso de parir, a identidade ficaria desfeita com a ditongação da vogal, como figura em Rodrigues (2003) e em Bechara (1999, p. 227), que anota:

Moderna e normalmente o verbo parir está incluído neste grupo: Pres. parimos e paris. Mas também, apesar de, por tabu lingüístico, ser desusado na linguagem de sociedade, pode ser conjugado integralmente, com irregularidade apenas na $1^{\text {a }}$ pess. do ind. e em todo o pres. do subj.: pairo, pares, pare, parimos, paris, parem. Pres. subj.: paira, pairas, paira, pairamos, pirais, pairam.

No entanto, seria criada outra coincidência formal com as formas do verbo pairar - o que enfraquece bastante a hipótese da defectividade pela confusão entre formas de verbos diferentes. Além disso, alguns outros verbos ficariam sem explicação - em especial os da coluna da direita, que são conjugados pela maioria dos autores consultados como de conjugação completa.

\subsection{Considerações finais}

É indiscutível que as duas gramáticas voltadas para falantes de português como língua materna, que não têm preocupação meramente didática, levam em conta a importante análise 
mórfica de Mattoso Câmara Jr. Em Bechara (1999), está mesmo reproduzida a descrição da estrutura verbal, com os morfemas característicos da vogal temática, e dos sufixos modotemporal e número-pessoal.

Na descrição dos verbos irregulares, ambos os gramáticos não se beneficiam dos padrões especiais para os verbos com variação no radical (do presente e do perfeito) descritos especialmente em Câmara Jr. (1972), deixando de generalizar pretensas especificidades, presos às velhas listas organizadas em ordem alfabética.

Mesmo quando Cunha; Cintra (1985) relacionam as ditas formas primitivas e derivadas, não há relevo para isso, pois os autores estabelecem essa relação nos verbos regulares, em que não há variação de radical nem nos grupos do presente, nem nos do perfeito. Tais relações só ficam claramente evidenciadas nos verbos irregulares, como mostram Gärtner (1998a) e Teyssier (1984).

Aliás, é preciso louvar a exposição feita por esses dois autores, bem como a de Vázquez Cuesta; Mendes da Luz (1980): sem menosprezar a organização e a clareza da informação, ultrapassam as preocupações meramente didáticas, podendo servir de consulta também ao usuário que já conhece a estrutura verbal em português. $\mathrm{O}$ mesmo não se pode dizer da exposição da morfologia verbal em Perini (2002), que pretende atingir o público universitário, apresenta lacunas e imprecisões no tratamento do tema (como a omissão da alternância vocálica, p.ex.).

Também merecem louvor Hutchinson; Lloyd (2002) e Abreu; Murteira (1998), que, valendo-se de uma organização de caráter claramente didático e despretensioso, não negligenciam a variação de radical mostrada pelo lingüista brasileiro. A julgar por alguns títulos ("irregularidades dos pretéritos", p.ex.), Masip (2000) obedeceria a esses princípios, mas não é isso efetivamente que acontece. Ao lado de alguns acertos, há graves equívocos (a inclusão de verbos regulares em listas de irregulares, p.ex.) - que comprometem a exposição que se pretende didática.

Além disso, a comparação da forma como os autores de gramáticas apresentam a morfologia verbal - especialmente nas voltadas para falante de português como língua estrangeira - suscita algumas curiosidades. Uma delas é tentar entender os critérios que nortearam a escolha dos verbos-modelo, que se multiplicam como se os autores tivessem bebido em fontes teóricas completamente diferentes. Não se pode esquecer que pelo menos a gramática 
de Celso Cunha e Lindley Cintra (ou a edição que lhe serviu de base) consta na bibliografia de todos os outros autores e a de Evanildo Bechara, em Masip (2000).

Isso pode ser um indicador de falta de rigor metodológico, caso se aceite a hipótese de que, na ilustração dos fatos lingüísticos, os autores usem o primeiro verbo que vem à lembrança. Aliás, em muitas dessas obras (Perini, 2002, Masip, 2000; Abreu; Murteira, 1998), a exposição da morfologia verbal deveria ter sido submetida a uma edição de texto que conduzisse a reformulações no conteúdo e na redação. É esse também o caso da exposição de Bechara (1999; 1975), de excelente conteúdo, mas que não apresenta a notável organização de Cunha; Cintra (1985).

Embora os dois autores das gramáticas voltadas para falantes de português como língua materna - assim como Gärtner (1998) e Teyssier (1984) -esses autores reúnam importantes informações sobre as alternâncias vocálicas, não se pode dizer que tenham chegado a uma descrição econômica e satisfatória desse grupo de verbos. Ressalte-se a criteriosa, mas também dispendiosa, descrição de Cunha; Cintra (1985), na tentativa de dar a esse grupo de verbo em cada uma das conjugações.

Além disso, a alternância continua na fronteira entre a regularidade e irregularidade problema que se tentará resolver, no Capítulo 3, com o levantamento quantitativo desses verbos.

Com relação aos verbos em -iar, os autores das gramáticas voltadas para falantes de português como língua materna fazem uma lista fechada para aqueles que seguem exclusivamente o paradigma dos verbos em -ear, mas propõem listas abertas para os verbos que são conjugados ora como os verbos em -ear, ora como os verbos em -iar, que abrigam um número imprevisível de verbos.

Finalmente, destacam-se as listas de verbos defectivos de Bechara $(1999,1975)$ e Cunha; Cintra (1985), que possibilitaram a comparação da conjugação proposta para esses verbos em três manuais de conjugação.

A tarefa não é propriamente original. Comparação do mesmo tipo de foi feita por Santos (1989), que se baseou em três obras diferentes das examinadas aqui: o Novo dicionário da língua portuguesa, de Aurélio Buarque de Hollanda Ferreira; o Dicionário de verbos e regimes, de Francisco Fernandes, e o Breviário da conjugação de verbos, de Otelo Reis).

Enquanto Santos (1989, p. 140), preocupado com o uso, conclui que as formas flexionais não constantes na norma padrão são condenadas por alguns professores que, numa postura "nada 
democrática" consideram ser "a norma padrão, ideal, concebida como a única válida é a que a camada social mais elevada domina", neste trabalho, procurou-se postular as razões pelas quais alguns verbos são descritos como defectivos, e não por que são mantidos como defectivos pela tradição didática.

O resultado aponta para a hipótese de Said Ali (1931) de que a dúvida a respeito da mudança no timbre da vogal pode fazer que o falante hesite entre duas formas, chegando mesmo a evitá-las para não incorrer em erro - o que parece confirmar-se no exame contrastivo dos verbos de terceira conjugação com alternância vocálica e/ou defectividade, feito no Capítulo 3.

Ainda que a omissão das formas rizotônicas resulte de uma solução arbitrária que os gramáticos normativos adotam para cumprir um dever do ofício - o estabelecimento de normas de uso -, essa arbitrariedade (que nada tem a ver com os direitos lingüísticos) só poderá ser contestada quando se tiver em mãos uma pesquisa sobre o uso atual das formas rizotônicas desses verbos por falantes brasileiros. 


\section{Capítulo 3}

\section{Morfologia do verbo no Dicionário Houaiss da língua portuguesa}

Este dicionário teve Antonio Houaiss, Mauro de Salles Villar e Francisco Manoel de Mello Franco como "diretores da equipe editorial" - o que os torna responsáveis pelo plano da obra (e, por isso, serão aqui denominados editores), executado por diferentes equipes, dentre as quais a de "redatores de elementos mórficos" (doravante denominados simplesmente redatores), que se revezaram em duas fases, sempre sob a coordenação de Roberto Cortes de Lacerda (Houaiss; Villar, 2001a, "Créditos do dicionário"; 2001b, p. XII).

Os 588 verbetes ( 585 de "terminações" e três "sufixos" verbais) deveriam dar conta da morfologia das 14.812 entradas de verbos (13.209 em -ar, $798 \mathrm{em} \mathrm{-er,} 764 \mathrm{em}-i r$, e ainda $p \hat{r}$ e quarenta derivados), mas há verbos para os quais, certamente por lapso na edição, não foram estabelecidas terminações que mantêm estreita semelhança com as estabelecidas.

Além disso, há 31 verbos que, por lapso na edição e/ou redação, não foram descritos em nenhum verbete de terminação. Nesses casos, foi necessário recorrer à tábua de conjugação, de responsabilidade de Vera Cristina Rodrigues (Houaiss; Villar, 2001a: Créditos do CD-ROM).

Finalmente, há quatro terminações que não deveriam ter sido estabelecidas por não apresentarem duas sílabas. Assim, o conjunto de verbetes descritivos da morfologia verbal a serem analisados neste Capítulo monta a 581 terminações, três sufixos, além de onze verbetes de verbos monossilábicos e 91 terminações não estabelecidas, embora possíveis.

Este Capítulo está organizado em quatro partes:

- 3.1 A terminologia, onde serão feitas considerações de natureza terminológica para que se evitem equívocos na análise do conjunto de verbetes.

- 3.2 O estabelecimento dos verbetes, onde se tentará identificar as supostas diretrizes para o estabelecimento do conjunto de terminações.

- 3.3 A REDAÇ̃̃o DO CORPO DOS VERBETES, onde se analisará o tratamento dado à morfologia verbal no conjunto dos verbetes.

- 3.4 ConsideraÇ̃os finais 
São de interesse:

- Apêndice 2 Verbetes descritivos da morfologia verbal examinados no Capítulo 3, útil quando se quiser ter acesso ao texto dos verbetes; à definição dos verbos pouco conhecidos, eventualmente citados aqui, e à lista de terminações por mim estabelecidas.

- Apêndice 3 - TerminaÇões quantificadas por grupos de interesse, analisadas no Capítulo 3 , útil quando se quiser verificar os dados numéricos discutidos aqui.

- Apêndice 4 - Ficha de conjugaÇão do presente do indicativo, onde se procura aplicar de maneira didática algumas das constatações deste estudo.

Foram utilizados os seguintes recursos gráficos:

- itálico, para palavras tomadas pelo significante, e não pelo significado;

- negrito, para as entradas dos verbetes, e

- negrito itálico, para destaque em citações (a fim de evitar repetir a todo momento a indicação de "[grifo meu]") e no texto do trabalho.

\subsection{A terminologia}

Primeiramente, será discutida a pertinência do uso de terminação e sufixo para a classificação dos respectivos verbetes. O mesmo será feito em relação aos termos metalingüísticos usados no corpo dos verbetes de forma imprecisa ou redundante - o que compromete, em maior ou menor grau, a compreensão dos conceitos a eles associados.

\subsubsection{USO DE TERMINAÇÃO E SUFIXO}

No verbete terminação, os redatores advertem que "as entradas de partículas verbais classificadas como term. (terminação) neste dicionário escapam à definição canônica do termo", ou seja, "desinência de uma palavra" (acepção 5 do mesmo verbete com a rubrica GRAM), sendo desinência definida (no respectivo verbete com a rubrica LING) como "sufixo flexional que aparece no final de vocábulos adicionando ao seu radical significados gramaticais".

É o que Cunha; Cintra (1985, p. 375) traduzem pela fórmula “= vOGAL TEMÁTICA + SUFIXo -r" quando tratam do infinitivo das três conjugações verbais, ou seja, as "terminações -ar, -er e -ir" a que se refere Bechara (1999, p. 225) na conceituação de verbo regular. 
Mesmo considerando-se que terminação pode, não canonicamente, ser interpretada como "o final de uma palavra" ou, canonicamente, como "o elemento sufixal ou desinencial" (Marouzeau, 1943, verbete terminaison ${ }^{42}$ ), causa espécie considerar -atir como "terminação" do verbo único latir, cujo segmento inicial fica reduzido à consoante $l$, ou ainda -arder como "terminação" do também único verbo arder, que fica então sem segmento inicial. Afinal, como observa Gleason Jr. (1961, p. 59):

Em geral, os afixos são subsidiários das raízes, enquanto estas são os centros das construções tais como palavras. As raízes são freqüentemente mais extensas que os afixos, e geralmente muito mais numerosas no vocabulário. ${ }^{43}$

Outras “terminações” identificam-se com aquilo que Cunha e Cintra (1985, p. 99-100), por "vantagens didáticas", consideram sufixo verbal: "a combinação de SUFIXo + vOGAL TEMÁTICA $(-a)+$ sufixo do infinitivo (-r), como em "afug-ent-ar". E listam então: -ear, -ejar, -entar, (i)ficar, -icar, -ilhar, -inhar, -iscar, -itar e -izar, aos quais se pode acrescentar aç(ar) e -ant(ar), mencionados por Bechara (1999, p. 364) dentre os "principais sufixos para formar verbos".

Na verdade, -ificar (mas não -ficar) pode ser considerado sufixo, como se pode ver já nos primeiro exemplos de -ficar:

-ficar el.comp. pospositivo, de verbos (e seus der.) provindos de v. latinos em -ficāre; estes são quase sempre de latinidade relativamente tardia (s II d.C. em diante), pois em realidade são todos baseados em facěre 'fazer', com apofonia, donde -ficěre, daí os passados para a $1^{\mathrm{a}}$ conj. lat. -āre; esse trânsito revelou-se fecundo no lat.vulg. e nas línguas român. (esp. -ficar, fr. -fier, it. -ficare); em port., a homofonia e homografia com ficar 'permanecer, estar sem trânsito, estabilizar-se' (de outro étimo, ver ficar) não parecem ter comprometido o uso dos dois (como se fez no esp. ficar $=$ quedar): todos os v. assim são causativos, isto é, indicam ações ou fatos em que o rad. principal é causado ou objetivado por -ficar; eis uns exemplos: acetificar, acidificar, aerificar, albificar, alcalificar, amplificar, beatificar, bestificar, bonificar, brutificar, burrificar, calcificar $[\ldots]$

Como lembra o lingüista americano, os afixos são subsidiários das raízes, e na maioria desses exemplos o morfema que se prende à raiz é -ificar, em comutação com outros morfemas o que fica evidente na comparação entre o verbo acidificar, o adjetivo ácido e o substantivo acidez.

Ressalte-se que, de acordo com as informações do próprio verbete, -ficar só pode ser considerado "elemento de composição pospositivo" no latim tardio - o que também não se aplica

\footnotetext{
${ }^{42}$ No original, "Terme employé de façon ambigüe pour désigner soit la finale d'un mot, quelle que soit sa nature, soit l'élément suffixal ou désinentiel tel que l'analyse le distingue".

${ }^{43}$ No original, "In general, affixes are subsidiary to roots, while roots are the centers of such constructions as words. Roots are frequently longer than affixes, and generally much mora numerous in the vocabulary."
} 
à maioria desses mesmos exemplos (como beatificar, em cujo verbete consta a etimologia "lat. beatifico, as, āvi, ātum, āre"), por oposição à maioria dos outros (acidificar, em cujo verbete consta a etimologia "ácido $+-i-{ }_{-}-$ficar", como se, em português, o - $i$ - fosse mera vogal de ligação).

A idéia expressa por Bechara (1999, p. 338) de que o sufixo "não tem curso independente na língua [...] é formador de "palavra nova, emprestando-lhe uma idéia acessória e marcando-lhe a categoria (substantivo, adjetivo, etc.) a que pertence" aparece no verbete sufixo ("afixo que, posposto a uma raiz, radical, tema ou palavra, produz formas flexionadas ou derivadas"), ficando bem claro que esse segmento tem força produtiva, como é o caso de -ar, que no dicionário é classificado como "sufixo".

Dois outros segmentos são indevidamente classificados como "sufixos" (-cer e -scer) ao lado das "terminações" -ecer e -escer - que, estas, sim, poderiam ser consideradas variantes gráficas de um mesmo sufixo (tendo -escer grafia "própria de palavras importadas que já chegaram à língua com -sc-, ou devidas à analogia”, como anota Bechara (1999, p. 364). Com relação a -(s)cer, assim como ocorre com -ficar, não podem ser considerados sufixos por não serem subsidiários de raiz.

Assim, teria sido possível manterem-se apenas -ecer e -escer como terminações, classificando como sufixo apenas -ar, a única terminação de infinitivo latino "usada na formação de novos verbos", segundo Allen Jr. (1941, §§ 147-61), que, ao tratar da formação de verbos em português, mostra poderem funcionar como sufixos: -ecer (em endurecer, vindo de duro + -ecer, diferentemente de aquecer, vindo do lat. adcalēscere), -ear (em ferretear, vindo de ferrete + -ear, diferentemente de jarretar, vindo de jarrete + -ar), -ejar (certamente em alvejar, mas não necessariamente em forcejar, que tanto pode ter vindo de força + -ejar quanto de forcejo + -ar), -entar (em endurentar e outros raros exemplos), -ilhar (em dedilhar e outros poucos exemplos) e -izar (em evangelizar e outros poucos exemplos). ${ }^{44}$

\footnotetext{
${ }^{44} \mathbf{1}^{\mathbf{}}$ ) No original, "-ar [...] It is the only of the Latin infinitive endings which is used in Portuguese in the formation of new verbs, and, among Portuguese verbal suffixes, it is one of the richest in examples [...]." $2^{\mathbf{0}}$ ) A produtividade do sufixo -ear fica ainda mais clara diante da variante jarretear registrada por Houaiss; Villar (2001a) para jarretar, "cortar o(s) jarrete(s), os tendões dos músculos posteriores da coxa a". 30) Em relação aos outros sufixos, o autor observa: para -antar, "has not been found in such [these ones of new verbs] formations"; para -escer, "a learned attempt to restore the latin form of the suffix"; para -icar, assim como -car, -igar, -egar, -gar, não é usado em "new formations in Portuguese"; para -inhar, "is not extended in new formations"; para -iscar "an apparent suffix", resultado de -isco, -isca + -ar (embora admita que fariscar pode ter sido formado a partir de faro "by the addition of -iscar, taken from the verbs above [beliscar, choviscar, lambiscar, mariscar, pestiscar]"); para -itar, terminação de verbos do latim clássico e do vulgar, não havendo "evidence of an extension of the suffix in the formation of new Portuguese verbs".
} 
De fato, nos verbetes das respectivas terminações, dentre outros, os redatores aludem ao valor sufixal, seja explicitamente como em -ejar ("com caráter sufixal”), seja implicitamente como em -ear ("dominantemente freqüentativos"), -ecer ("como incoativo"), -entar ("v. ditos causativos") e -izar (“com caráter freqüentativo").

Sem negligenciar o fato de que o estabelecimento dessas terminações dá continuidade a uma tradição gramatical desvinculada da descrição lingüística, neste Capítulo terminação designará cada um dos segmentos assim classificados pelos lexicógrafos.

\subsubsection{USO DE PADRÃo, PARADIGMA, MODELO E GRUPO}

No corpo dos verbetes de terminação, padrão corresponde a paradigma - que, na acepção 12 de seu respectivo verbete, é definido como o "conjunto de formas vocabulares que servem de modelo para um sistema de flexão ou de derivação (p.ex.: na declinação, na conjugação etc.); padrão", com a rubrica GRAM -, como em -iar (“acusam a um tempo o padrão regular de assobiar e o irregular de ansiar").

Com o mesmo sentido, são usados: o próprio paradigma, como em -uar ("há, porém, certa confusão de paradigmas em -oar e -uar"); modelo, como em -oer ("o modelo de moer serve, em princípio, de paradigma”); grupo, como em -edir (“os v. da língua com esta term. pertencem ao grupo 1) de -gredir [...] ao grupo 2) de pedir [...]”), e mesmo subpadrão em -uir (“o [padrão] dos v. argüir, delinqüir, redargüir, com dois subpadrões (o de argüir e redargüir)"). ${ }^{45}$

Todavia, o principal uso de padrão está no verbete terminação ("padrões de alteração gráficos, históricos, semânticos e/ou morfológicos ocorridos em cada grupo citado"), com o sentido de conjunto de particularidades manifestadas nos grupos de verbos de cada uma das terminações. No mesmo verbete, paradigma assume então o sentido de modelo ("paradigmas em torno dos quais tais [verbos] se grupam"). ${ }^{46}$

\footnotetext{
${ }^{45}$ Em Houaiss; Villar (2001b, p. XLV), padrão e paradigma também são usados como sinônimos: "7 Regularidade - "São chamados verbos regulares da $1^{\text {a }}$ conjugação todos os verbos que se conjugam como o padrão ou paradigma amar $[\ldots]$..."

${ }^{46}$ Em Houaiss; Villar (2001b, p. XLV), nota-se confusão entre padrão e subpadrão na descrição da alternância vocálica: "diverge desse padrão ["9.1.1", caracterizado pela abertura das "vogais $e$ e $o$ do radical"] o verbo chegar e seus derivados", e "divergem desse subpadrão ["9.1.2 b", caracterizado pelaausência de alternância "nos verbos cuja vogal radical $o$ ou $e$ é seguida de consoante nasal ou de consoante palatal"] os verbos invejar, embrechar, flechar, frechar e vexar, que retornam ao subpadrão 9.1.1 supra [ausência de alternância "nos verbos cuja 'vogal' radical é em verdade um ditongo radical]".
} 
Neste Capítulo, padrão passa a designar o conjunto de particularidades comuns a verbos em várias terminações morfológicas, e paradigma, as particularidades de um grupo de verbos dentro de uma terminação.

\subsubsection{USO DE ABUNDANTE, CO-REGULAR, DEFECTIVO, IRREGULAR E REGULAR NA QUALIFICAÇÃO DOS VERBOS}

Em 431 verbetes, os verbos são declarados simplesmente "regulares", como em -apar ("todos os v. da língua com essa term. são regulares"). Na maioria deles, a declaração de regularidade vem seguida da descrição de particularidades morfológicas, como em -aipar (“. todos os v. da língua com essa term. regulares, isto é, preservam o ditongo ai tanto nas $\mathrm{f}$. rizotônicas como nas arrizotônicas"). ${ }^{47}$

Em -arrir (“o v. barrir, metaforicamente conjugado, só é defectivo na $1^{\mathrm{a}}$ p.s. pres.ind. e pres.subj.; o verbo garrir só é conjugado nas f. arrizotônicas") e outros catorze verbetes, os verbos são declarados "defectivos", em uma forma rizotônica (barrir) ou nas quatro (garrir) do presente do indicativo e, nos dois casos, em todas as do presente do subjuntivo. Não raro, os verbos são considerados regularizados, como em -arcir (o v. ressarcir, tido como defectivo (na $1^{\text {a }}$ p.s.pres.ind. e, decorrentemente, no pres.subj., e, antes, em todas as f. rizotônicas), é hoje em dia regular"). ${ }^{48}$

Em apenas três verbetes, os verbos são declarados irregulares em suas formas flexionadas. Além disso, a irregularidade (eventualmente associada à abundância) vem declarada para o particípio de alguns verbos, como em -ender ("alguns, além do part. regular (tipo acendido), têm um segundo, irregular").

Diante dessa clara resistência à rotulação - observada também nos textos de Câmara Jr. (1972, 1970), conforme se viu no Capítulo 1, item 1.2 -, é curioso que falem em "verbos coregulares" e "co-regularidade" em três verbetes ${ }^{49}$ :

-air term. [...] são co-regulares, conjugáveis segundo o padrão, p.ex., de sair: saio, sais, sai, saímos, saís, saem; saía etc.; saí, saíste, saiu, saímos, saístes, sairram; sairei etc.; sairia etc.; saia, saias, saiamos, saiais, saiam; saísse etc.; sair, saíres, sair, sairmos, sairdes, sairem; saindo; saído [...]

\footnotetext{
${ }^{47}$ Para as terminações correspondentes a verbos declaradamente regulares, Cf. Apêndice 3, item 3.1.

${ }^{48}$ Para as terminações correspondentes a verbos declaradamente defectivos, irregulares, abundantes e coregulares, Cf. Apêndice 3, item 3.2.

${ }^{49}$ Em -uer, o termo também aparece (“a conj., co-regular dos vários v. citados, segue o paradigma ergo, ergues [...]”), mas o verbete, por ser atípico, não está sendo considerado nesta análise. Além disso, se houvesse mesmo co-regularidade nos "verbos em -uer", a observação deveria ter sido feita em -erguer, já que "os v. terminados graficamente em -uer [...] só ocorrem com a sílaba final -guer e tão-somente nos comp. de erguer".
} 
-ear term. há por vezes cruzamentos entre os v. em -ear e os em -iar; mas o padrão culto oferece extrema co-regularidade em todos os v. em causa; tome-se, como paradigma, o v. nortear: norteio, norteias, norteia, norteamos, norteais, norteiam; norteava etc.; norteei etc.; nortearei etc.; nortearia etc.; norteie, norteies, norteie, norteemos, norteeis, norteiem; norteasse etc.; nortear etc.; norteando; norteado [...]

-iar term. [...] não apresenta a co-regularidade de -ear, mas seus v., em grande maioria, seguem o padrão, tomado aqui como exemplo, de assobiar [...]; há, entretanto, uns quantos - como ansiar e odiar - que cruzam as f. rizotônicas como se fossem em -ear (anseio/odeio, anseias/odeias [...], mas ansiemos/odiemos, ansieis/odieis) e uns quantos outros - como agenciar [...] - que acusam a um tempo o padrão regular de assobiar e o irregular de ansiar [...]

Não estando co-regular e co-regularidade registrados no dicionário, é preciso interpretar o que os redatores querem dizer quando usam os dois termos. É possível pensar que qualquer verbo é co-regular dos que seguem rigorosamente o mesmo paradigma: copiar poderia ser coregular de assobiar, tanto quanto os verbos em -air e -ear o são em relação a sair e nortear, respectivamente. Entretanto, se assim fosse, os redatores não teriam usado o rótulo apenas nesses três verbetes. Resta saber, então, se há algo em comum entre eles.

No "padrão" de sair e no "paradigma" nortear - que serve tanto para os verbos em -ear quanto para uma pequena parcela dos verbos em -iar, conforme se viu no Capítulo 1, item 1.4.1.1 -, há uma semivogal entre a vogal radical e a desinência número-pessoal em saio e norteio, e anseio (e em todas as formas do presente do subjuntivo). No entanto, diferentemente do que ocorre com norteias, norteia e norteiam, e com anseias, anseia e anseiam (em que à vogal radical ditongada se segue a vogal temática $a$ ), em sais e sai a semivogal $i$ corresponde à vogal temática $e$ em ditongo com a vogal radical, não havendo em saem nenhum dos dois tipos de ditongação.

Não se pode, portanto, dizer que a ditongação sistemática nas formas rizotônicas caracteriza a co-regularidade, única razão que poderia explicar a afirmação de que os verbos em -iar (nos quais a ditongação não é sistemática) apresentam a co-regularidade dos em -ear - o que faz concluir ser o rótulo indevido.

Assim, neste Capítulo, aos assim chamados regulares opõem-se os verbos defectivos em uma forma, para os defectivos na primeira pessoa do presente do indicativo (e em todas as do presente do subjuntivo); verbos defectivos em quatro formas, para os defectivos nas quatro formas rizotônicas do presente do indicativo (e em todas as do presente do subjuntivo); verbos defectivos regularizados, para os assim declarados ou "tidos como defectivos", e verbos com formas não-regulares, para os restantes. 


\subsubsection{USO DE RADICAL DO PERFEITO, FORMAS RIZOTÔNICAS E ARRIZOTÔNICAS}

Além de em -aber e -aver, radical do perfeito aparece apenas em:

-azer term. 1) fazer [...] tem no pres.ind. faço (donde pres.subj. faça etc.), fazes, faz, fazemos etc.; rad. do perf. fiz, fizeste, fez, fizemos etc. (donde fizera etc., fizesse etc., fizer etc.), part. feito, fut. farei etc., fut.pret. ou cond. faria etc.; 2) jazer [...] é modernamente regular, salvo na $3^{\text {a }}$ p.s.pres.ind. jaz; 3) prazer $[\ldots]$, salvo na $3^{\text {a }}$ p.s.pres.ind. que faz praz, é regular, subsistindo, porém, no rad. do perf., a par da $\mathrm{f}$. moderna regular prazi etc. [...], a f. antiga prouve etc. (prouvera etc., prouvesse etc., prouver etc.); 4) trazer $[. .$.$] tem no pres.ind. trago (donde todo o pres.subj. traga, tragas$ etc.), trazes, traz, trazemos, trazeis, trazem, perf. trouxe etc. (donde trouxera etc., trouxesse etc., trouxer etc.), fut. trarei etc. e fut.pret. ou cond. traria etc.

O termo é usado na descrição de fazer e prazer, mas não de trazer, onde trouxe é identificado como forma básica para trouxera, trouxesse e trouxer. De fato, conforme se viu no Capítulo 1, item 1.1.3, o radical do perfeito é encontrado no pretérito perfeito e mais-que-perfeito do indicativo, bem como no pretérito imperfeito e no futuro do subjuntivo. A escolha da forma básica, porém, não é arbitrária, como os redatores do verbete dão a entender no caso de fazer: "fiz, fizeste, fez, fizemos etc. (donde fizera etc., fizesse etc., fizer etc.)".

Conforme se viu ainda no Capítulo 1, item 1.4.2, só poderiam ser consideradas básicas fizeste, fizestes ou fizeram, que, além de variação no radical, apresentam vogal temática característica. É por isso que Bechara (1999, p. 237) não fala em radical do perfeito, mas em "tema do pretérito perfeito do indicativo". Além do pretérito perfeito do indicativo, identifica assim como Cunha e Cintra (1985) - dois outros "tempos primitivos": o presente do indicativo e o infinitivo impessoal.

No presente do indicativo, a forma que comum ao tempo primitivo e aos tempos derivados já não é mais a mesma, como os redatores deixam claro: "faço (donde pres.subj. faça etc.)"; "trago (donde todo o pres.subj. traga, tragas etc.)". Trata-se, conforme se viu no Capítulo 1, item 1.4.1.2, de verbos com radical do infinitivo variável em uma forma rizotônica do presente do indicativo e no presente do subjuntivo.

A tonicidade em uma das sílabas do radical ou fora dele importa também para os verbos:

- defectivos, aos quais podem faltar uma ou mais formas rizotônicas, como descrito em -arcir (“o v. ressarcir, tido como defectivo (na 1ª.s.pres.ind. e, decorrentemente, no pres.subj., e, antes, em todas as f. rizotônicas), é hoje em dia regular");

- com oscilação na tonicidade, como descrito em -aguar ("há neles controvérsia preceptiva quanto à acentuação nas f. rizotônicas, mas a distinção gráfica -guar de 
-goar visa às possibilidades da silabação [...], donde, correlatamente, a acentuação nas f. rizotônicas"), e

- com alternância vocálica, como descrito em -ebar (os poucos v. da língua com esta term. têm a vogal -e-, nas f. rizotônicas, aberta”)

Com exceção dos defectivos, são todos casos de verbos que, aqui, passam a ser chamados de variação de radical no grupo do presente, por oposição aos verbos com variação de tema no grupo do perfeito.

\subsubsection{USO dE OS, TODOS E OS POUCOS NA QUANTIFICAÇÃo DOS VERBOS}

Há três principais redações para a parte introdutória do corpo dos verbetes: "term. os $\boldsymbol{v}$. $\boldsymbol{d a}$ língua com essa term. (despilchar, empilchar) são regulares" (como em -ilchar); "term. todos os v. da língua com essa term. são regulares" (como em -alfar) e - "term. os poucos v. da língua com essa term. são regulares" (como em -arjar).

As duas primeiras são equivalentes. Dizer "os verbos" ou "todos os verbos" resulta no

mesmo, ainda que "os verbos" de -ilchar, "todos os verbos" de -alfar - e também "os poucos verbos" (sarjar e tarjar) de -arjar - sejam sempre dois (despilchar, empilchar, de um lado, e escalfar e esfalfar, de outro).

Basta a comparação entre os três verbetes para se constatar a fragilidade no critério de escolha de um desses três modelos de redação em função do número de verbos incluídos em cada uma dessas terminações. No caso de terminações com alguma particularidade relevante, as informações do verbete podem falsear a análise quantitativa dos verbos por especificidades de conjugação. Isso fica bem claro quando se verifica, p.ex., que "os poucos v. da língua" de -obar, com alternância vocálica, montam a dezenove.

Quantos seriam, afinal, “poucos verbos”? Qualquer índice a ser fixado seria arbitrário, de modo que teria sido mais prudente falar apenas em "os verbos", chamando atenção para as terminações de baixa ocorrência, que aqui designam as correspondentes a um verbo (como -atir, unicamente para latir) ou a dois (como -onjar, para esponjar e lisonjar), especialmente quando se trata de variantes (como -arrer, para varrer e barrer) ou derivados (-enzer, para benzer e rebenzer). 


\subsection{O ESTABELECIMENTO DOS VERBETES DE TERMINAÇÃO}

Primeiramente, serão caracterizadas as terminações, quatro delas atípicas - o que reduz a 581 o conjunto das verdadeiras terminações estabelecidas. Em seguida, serão examinadas 82 terminações que, por uma questão de uniformização, deveriam ter sido estabelecidas, bem como algumas terminações que deveriam ter sido estabelecidas em mais de uma entrada, por mais dispendiosa que fossem essas duas medidas. Finalmente, será posto e relevo o caráter antieconômico e pouco eficaz da descrição da morfologia verbal no conjunto de terminações verbais.

\subsubsection{TeRminações ESTABELECIDAS}

Em seu manual de conjugação verbal, Nogueira (1963) também estabelece 359 tábuas de conjugação verbal, sendo que a maioria das terminações é de duas sílabas. Dentre umas poucas monossilábicas, -dar (para o verbo dar) e -ir (para o ver rir) destoam de -guar, -guir, -quar, -quir, -ir) e outras, de duas (-aizar, -anciar, -eizar, -enciar, -guentar, -iudar, -quentar, -unciar).

Como as terminações não foram caracterizadas do ponto de vista formal, só o exame da totalidade dos verbetes permite verificar que, com exceção de -er e -ir, as terminações caracterizam-se por serem constituídas de duas sílabas, sendo:

- a primeira livre (como em -elar) ou travada (como em -erlar e -oiar)

- a segunda constituída por -ar, -er e -ir antecedidos de consoante (como em -ater), dígrafo (como em -uprir).

Tanto é assim que os verbos com hiato no radical foram tratados nas terminações iniciadas pela segunda vogal do hiato e os verbos com ditongo no radical forma tratados em verbete próprio, como se pode ver na comparação entre:

-umar term. os v. da língua com essa term. são regulares; aziumar e ciumar têm o -ugraficamente acentuado nas f. rizotônicas (aziúmo, ciúmas, aziúma, ciúmam, aziúme, ciúmes, ciúmem)

-eumar term. o v. da língua com esta term., afleumar, é regular, preservando o ditongo fechado $-e u$ -

Só -eizar foi estabelecida para descrever verbos com hiato no radical, em duplicidade com -izar: 
-izar term. [...] os muitos v. da língua com essa term. são regulares; quando essa term. é precedida de vogal (ajuizar, arcaizar, desajuizar, desenraizar, desjuizar, desraizar, emboizar, enraizar, europeizar, hebraizar, judaizar, plebeizar), o $i$ se faz graficamente acentuado nas f. rizôtonicas (-aízo, -eízo, -uízo, -aíze, -eíze, -uíze etc.)

-eizar term. os dois v. que consignam esta term. (homogeneizar e heterogeneizar) fazem, nas f. rizotônicas, hiato típico: homogeneízo, heterogeneízas, homogeneíza, heterogeneízam, homogeneize etc."

Isso faz pensar na possibilidade de o encontro vocálico em homogeneizar e heterogeneizar ter sido considerado um ditongo, ao contrário de europeizar e plebeizar, em que foi considerado hiato. Essa hesitação pode encontrar explicação em Bisol (1999, p. 723) de que, nos ditongos: 
Todas as vogais entram como núcleos silábicos, inclusive as altas, mas quando o processo de silabação começa, vogais altas, adjacentes a vogais não-altas, são incorporadas à coda $[\ldots]$

De acordo com essa análise da sílaba como possuidora de uma estrutura interna de constituintes, a semivogal de arcaizar, europeizar (e homogeneizar), emboizar e ajuizar em estado pré-silábico têm estatuto de vogal - o que pode gerar a realização do encontro vocálico ora como ditongo, ora como hiato.

Além de -eizar, outras três "terminações" não são constituídas de duas sílabas: -orizar, composta igualmente de três sílabas; lhar, composta de uma única sílaba, e -uer, que não passa de fragmento de sílaba, estabelecida, ao lado de -erguer, provavelmente porque, em -uir, há remissão indireta às terminações correspondentes aos verbos "em que o -u- não é pronunciado, é mero recurso gráfico, como nos casos tratados em -erguer, -anguir, -anquir, -eguir, -equir, -inguir, -orquir".

As duas primeiras devem ter sido estabelecidas - também indevidamente - em função de sua relação com sufixos nominais: "dos v. terminados em -izar, há não poucos em -orizar, verbos correspondentes parte final do voc. de base [-or(ia) ou -or $(o / a)]+-i z a r$ " e "-lhar, em verdade, pode ter um suf. - Ih(a/o), de -cula-/-culu-, + o - $a$ - da vogal temática da $1^{\text {a }}$ conj.." ${ }^{50}$

Assim, descontadas essas três terminações - e também -acir que, sem corresponder a nenhum verbo registrado no dicionário, deve ter sido estabelecida por lapso de edição -, foram estabelecidas 581 verdadeiras terminações.

\subsubsection{TERMINAÇÕES NÃO-ESTABELECIDAS}

A omissão de 91 terminações poderia explicar-se pelo fato de que $85 \%$ delas são de baixa ocorrência, ou seja, correspondem a um ou a dois verbos. ${ }^{51}$

No entanto, essa hipótese não se sustenta quando se comparam esses índices com os de terminações estabelecidas, conforme se pode ver na Tabela 3.1.

\footnotetext{
${ }^{50}$ Note-se que nem -lhar, nem -lha encontram registro em Bechara (1999), Cunha e Cintra (1985) e Allen Jr. (1941).

${ }^{51}$ Para as terminações de baixa ocorrência, Cf. Apêndice 3, item 3.3 e, para as terminações que, se estabelecidas, seriam do mesmo tipo, Cf. Apêndice 2, itens 2.4.1 a 2.4.6.
} 


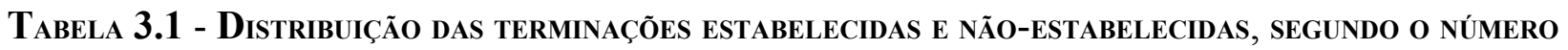 DE VERBOS}

\begin{tabular}{lcccc}
\hline \multirow{2}{*}{ terminações } & \multicolumn{2}{c}{ estabelecidas } & \multicolumn{2}{c}{ não } \\
no de verbos & $\mathrm{n}^{\text {o }}$ & $\%$ & $\mathrm{n}^{\mathrm{o}}$ & $\%$ \\
\hline um ou dois & 124 & 21,2 & 79 & 86,8 \\
três ou mais & 461 & 78,8 & 13 & 13,2 \\
total & 585 & 100,0 & 91 & 100,0 \\
\hline
\end{tabular}

Fonte: Apêndice 3, item 3.3 e Apêndice 2, itens 2.1, 2.4.1 a 2.4.6

Embora apenas 21,2 \% das terminações estabelecidas sejam de baixa ocorrência, em números absolutos (124) elas superam significativamente não só as não-estabelecidas do mesmo tipo (79), como também o total de terminações não estabelecidas (91).

Poderia explicar-se também caso o número de terminações não-estabelecidas correspondentes a verbos simplesmente classificados como regulares, sem descrição do comportamento verbal, fosse majoritário em relação aos outros. Não é isso, porém, o que mostram os dados da Tabela 3.2..$^{52}$

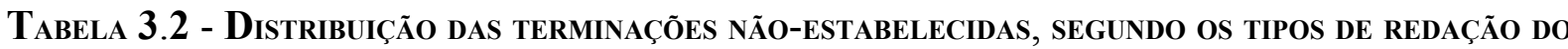 CORPO DO VERBETE}

\begin{tabular}{lrrrrc}
\hline \multirow{2}{*}{ tipos de redação } & \multicolumn{2}{c}{ estabelecidas } & \multicolumn{3}{c}{ não } \\
& \multicolumn{1}{c}{ estabelecidas } \\
& \multicolumn{1}{c}{$\mathrm{n}^{\mathbf{0}}$} & \multicolumn{1}{c}{$\%$} & \multicolumn{1}{c}{$\mathrm{n}^{\mathbf{0}}$} & \multicolumn{1}{c}{$\%$} \\
\hline simplesmente regulares & 182 & 31,1 & 29 & 31,8 \\
regulares com descrição de particularidades morfológicas & 249 & 42,6 & 30 & 33,0 \\
derivados de verbos monossilábicos & 12 & 2,1 & 15 & 16,5 \\
de terceira conjugação em que o $u$ é semivogal ou ditongo & 6 & 1,0 & 9 & 9,9 \\
antigos ou pouco usados & 7 & 1,2 & 8 & 8,8 \\
outros & 129 & 22,0 & 0 & 0 \\
total & 585 & 100,0 & 91 & 100,0 \\
\hline
\end{tabular}

Fonte: Apêndice 3, itens 3.4 e 3.5 e Apêndice 2, itens 2.4.1 a 2.4.6

Em relação às terminações correspondentes a verbos declarados simplesmente regulares, o percentual é praticamente o mesmo para as estabelecidas $(31,1 \%)$ e as não-estabelecidas $(31,8 \%)$, mas algumas destas últimas corresponderiam a verbos muito mais usados (calibrar, equilibrar, vibrar, p.ex.) do que os descritos em certas terminações estabelecidas, como -ubrar (“os v. elucubrar e lucubrar são regulares”).

\footnotetext{
${ }^{52}$ Para as terminações correspondentes a verbos simplesmente classificados como regulares, Cf. Apêndice 3, item 3.4 e, para as terminações que, se estabelecidas, corresponderiam a verbos do mesmo tipo, Cf. Apêndice 2 , item 2.4.1.
} 
Não é muito menor o percentual de terminações que corresponderiam a verbos declarados regulares com descrição de suas particularidades $(33,0 \%)$ em relação às estabelecidas $(42,6 \%)$. Aqui também foram negligenciadas terminações correspondentes a verbos tão importantes (alegrar, integrar e regrar, p.ex.) quanto os registrados em -ograr (“os poucos v. da língua com essa term. são regulares, com o -o- aberto nas f. rizotônicas (deslogro, logras, malogra, sogram, deslogre, logres, malogre, sogrem)").

Chamam atenção os casos em que o percentual de terminações não-estabelecidas é muito mais alto do que o das estabelecidas: para derivados de verbos monossilábicos, 16,5\% contra 2,1\%; para verbos de terceira conjugação em que o $u$ é semivogal ou ditongo, $9,9 \%$ contra $1,0 \%$, e para verbos antigos ou pouco usados, $8,8 \%$ contra $1,2 \%$.

É preciso notar que - ao lado de -abster e -advir - os editores não estabeleceram treze terminações que corresponderiam a derivados de pôr. Se esse verbo, diferentemente dos outros monossilábicos da segunda conjugação, não foi mencionado em -er ("há nela os segg. v. monossilábicos no inf. pessoal: crer, ler, ser, ter e ver"), é muito possível que as terminações correspondentes a seus derivados não constem por lapso na edição. ${ }^{53}$

Assim também, sete verbos de uso antigo (como trager) ou raro (como demulcir) ou restrito a determinados países de língua portuguesa (como cuxir) só foram descritos em seu próprio verbete, mas outros verbos na mesma condição (raer, envaidar, gualdir e condir) mereceram verbete de terminação (-aer, -aidar, -aldir e -ondir). ${ }^{54}$

Tudo leva a crer, portanto, que essas 91 terminações tenham sido negligenciadas no processo de edição do texto.

\subsubsection{TERMINAÇÕES QUE DEVERIAM TER SIDO ESTABELECIDAS EM MAIS DE UMA ENTRADA}

Se os critérios para o estabelecimento das terminações do ponto de vista formal não foram estabelecidos, não se pode dizer o mesmo com relação à sua função. No verbete terminação, os editores advertem que:

[...] as entradas de partículas verbais classificadas como term. (terminação) neste dicionário escapam à definição canônica do termo, tendo sido estabelecidas após a verificação dos paradigmas em torno dos quais tais se grupam, com o fito de possibilitar

\footnotetext{
${ }^{53}$ Para as terminações correspondentes a derivados de verbos monossilábicos, Cf. Apêndice 3, item 3.5 e, para as terminações que, se estabelecidas, corresponderiam a verbos do mesmo tipo, Cf. Apêndice 2, item 2.4.3.

${ }^{54}$ Para as terminações correspondentes a verbos fósseis ou pouco usados (-aer, -aidar, -apir, -implir, -obvir, -odrir, -olvar, -ondir, -onir e -onzar), Cf. Apêndice 2, item 2.1, e, para as terminações que, se estabelecidas, corresponderiam a verbos fósseis ou pouco usados, Cf. Apêndice 2, item 2.4.6.
} 
a identificação dos padrões de alteração gráficos, históricos, semânticos e/ou morfológicos ocorridos em cada grupo citado [...]

Dada a falta de clareza em determinados trechos do corpo do verbete, é-se obrigado a supor que tenha havido salto em "paradigmas em torno dos quais tais [verbos] se grupam", podendo-se entender, assim, que diferentes terminações- correspondentes a verbos com um mesmo paradigma - constituem um determinado padrão, como ocorre com

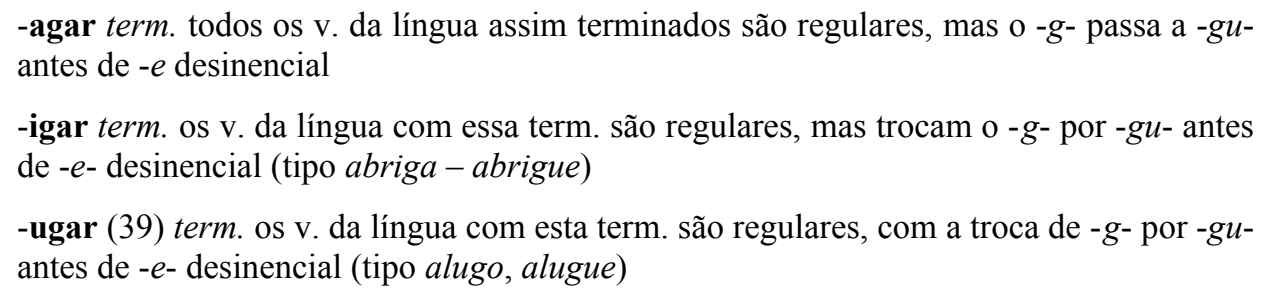

$\mathrm{O}$ mesmo não se verifica em -egar, correspondente a verbos que "têm aberto o - $e$ - nas $f$. rizotônicas, além de mudarem o -g- em -gu- antes de -e- desinencial [...]; chegar [...] tem, entretanto, o -e- rizotônico fechado [...]". Há, aí, dois paradigmas: o dos verbos com alternância vocálica, que seguem o mesmo padrão dos verbos em -ergar ("têm o -e- aberto nas f. rizotônicas e a mudança do - $g$ - em - $g u$ - antes do -e- desinencial") e em -elgar, que não foi estabelecida, mas corresponderia ao verbo único adelgar..$^{55}$

São 68 as terminações correspondentes a verbos que seguem paradigmas diferentes, das quais:

- 61, com dois paradigmas, como em -ular (“os v. da língua com esta term. são regulares; se a term. é precedida de vogal [...], o -ú- se grafa acentuado nas $f$. rizotônicas: abaúlo [...]");

- três, com três paradigmas, como em -edar ("os v. da língua com esta term. têm o -eaberto nas $f$. rizotônicas: alamedo [...]; o v. apiedar [...] muda tradicionalmente esse -e- rizotônico em -a-: apiado [...], mas hoje em dia abona-se tb. apiedo etc.; o v. redar conjuga-se como dar, no sentido de 'dar novamente'[...]"), e

- quatro, com mais de três paradigmas, como em -azer term. 1) fazer [...] tem no pres.ind. faço (donde pres.subj. faça etc.), fazes, faz, fazemos etc.; rad. do perf. fiz, fizeste, fez, fizemos etc. (donde fizera etc., fizesse etc., fizer etc.), part. feito, fut. farei etc., fut.pret. ou cond. faria etc.; 2) jazer [...] é modernamente regular, salvo na $3^{\mathrm{a}}$ p.s.pres.ind. jaz; 3) prazer [...], salvo na $3^{\text {a }}$ p.s.pres.ind. que faz praz, é regular,

\footnotetext{
${ }^{55}$ Para terminações correspondentes a verbos que seguem paradigmas diferentes, Cf. Apêndice 3, item 3.6.
} 
subsistindo, porém, no rad. do perf., a par da f. moderna regular prazi etc. (com prazera, prazesse, prazer etc.), a f. antiga prouve etc. (prouvera etc., prouvesse etc., prouver etc.); 4) trazer [...] tem no pres.ind. trago (donde todo o pres.subj. traga, tragas etc.), trazes, traz, trazemos, trazeis, trazem, perf. trouxe etc. (donde trouxera etc., trouxesse etc., trouxer etc.), fut. trarei etc. e fut.pret. ou cond. traria etc.

Essas terminações teriam merecido mais de uma entrada, assim como o verbo redar mereceu três entradas diferentes:

${ }^{1}$ redar $v$. (1798 cf. Eluc) VITIC t.d. m.q. redrar [tornar a cavar (a vinha) para livrar de ervas a área contígua ao pé $] \odot$ ETIM alt. de redrar $\odot$ HOM $\operatorname{rede}\left(1^{\mathrm{a}} 3^{\mathrm{a}}\right.$ p.s. $)$, redes $\left(2^{\mathrm{a}}\right.$ p.s. $) /$ rede /ê/ (s.f.) e pl.

${ }^{2}$ redar v. (1836 cf. SC) p.us. 1 t.d.bit. dar mais uma vez; tornar a dar 2 t.d.bit. dar repetidamente $\odot$ GRAM a respeito da conj. deste verbo, ver gram no verbete dar $\odot$ ETIM re- + dar; ver $d a(d)-\odot$ HOM ver ${ }^{1}$ redar

${ }^{3}$ redar $v$. int. atirar a rede $\odot$ ETIM rede + -ar; ver $\operatorname{red}(i)-\odot$ HOM ver ${ }^{1}$ redar

Assim, a terminação correspondente deveria ter sido estabelecida em três entradas "com um algarismo alceado à esquerda da unidade léxica - de acordo com recomendação dos editores para homônimos homógrafos homófonos de qualquer categoria gramatical e também para os elementos mórficos “1-fugo" e “2-fugo” (Houaiss; Villar, 2001b, p. XVIII-XIX) -, tal como ilustrado no Quadro 3.1.

\section{Quadro 3.1 - Estabelecimento EFetivo e POSSível De - EDAR}

\begin{tabular}{|c|c|}
\hline & 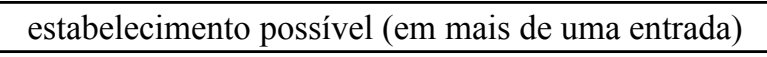 \\
\hline $\begin{array}{l}\text {-edar term. os v. da língua com esta term. têm o } \\
\text {-e- aberto nas f. rizotônicas: alamedo, alevedas, } \\
\text { almoeda, amoedam, aquede, arredes, arremede, } \\
\text { azedem; o v. apiedar (e despiedar e desapiedar) } \\
\text { muda tradicionalmente esse -e- rizotônico em } \\
\text {-a-: apiado, despiades, desapiadem etc., mas } \\
\text { hoje em dia abona-se tb. apiedo etc.; o v. redar } \\
\text { conjuga-se como dar, no sentido de 'dar } \\
\text { novamente', e como o padrão acima, no sentido }\end{array}$ & $\begin{array}{l}\text { '-edar term. os v. da língua com esta term. têm o -e- } \\
\text { aberto nas f. rizotônicas: alamedo, alevedas, } \\
\text { almoeda, amoedam, aquede, arredes, arremede, } \\
\text { azedem; assim se conjuga o v. redar no sentido de } \\
\text { 'jogar rede'; o v. apiedar (e despiedar e desapiedar) } \\
\text { muda tradicionalmente esse -e- rizotônico em -a-: } \\
\text { apiado, despiades, desapiadem etc., mas hoje em dia } \\
\text { abona-se tb. apiedo etc. } \\
\text { 'edar o v. redar conjuga-se como dar, no sentido de } \\
\text { 'dar novamente' }\end{array}$ \\
\hline
\end{tabular}

Note-se que, havendo um verbo apiadar, mesmo que registrado como de uso informal e antigo e com simples remissão para apiedar, não se pode considerar que, neste último verbo, haja mudança de vogal nas formas rizotônicas. É por isso que Bechara (1999, p. 244) contesta “a lição antiga de alguns gramáticos e ortógrafos [a qual] confundia o arcaico apiadar e o clássico apiedar numa só conjugação”. 


\subsubsection{A falta de economia}

A falta de economia fica denunciada já no estabelecimento das terminações de baixa ocorrência: em 124 terminações (62 correspondentes a um verbo e outras em igual número, a dois) são descritos apenas 182 verbos. Isso sem contar as 75 terminações (55 que corresponderiam a um verbo e 20, a dois) que, se estabelecidas, corresponderiam a um total de 94 verbos.

Além disso, o sistema não é prático. O usuário interessado na conjugação de despir ou crespir encontrará no verbete do verbo a remissão para o de terminação (“GRAM a respeito da conj. deste verbo, ver -espir"). Será obrigado a consultar, então, um segundo verbete (-espir) para saber que "o v. despir faz na $1^{\mathrm{a}}$ p.s. do pres.ind. dispo (donde todo o pres.subj. dispa etc.), regularizando-se nas demais f., sendo que as rizotônicas têm o -e-aberto; crespir, raro de uso, tende a seguir esse padrão" - com toda a imprecisão conferida pelo uso do verbo tender no caso de crespir. Não é preciso dizer que, diante de tantos atalhos, o usuário da versão eletrônica não hesitará em consultar a tábua de conjugação.

Quem estiver interessado na conjugação de desdar nem mesmo suspeitará da existência do verbete de -esdar ("o só v. da língua com esta term. é der. de dar e se conjuga como este (desdou, desdás, desdá etc.)"), pois em seu verbete, há remissão para o verbete do verbo primitivo (“GRAM a respeito da conj. deste verbo, ver gram no verbete dar").

Tampouco é econômico um sistema que prevê o estabelecimento de verbetes para se declaram apenas que "os poucos v. da língua com essa term. são regulares" (em -ifrar), ou que “os v. da língua com essa term. são regulares" (em -iver), ou ainda que "o v. suprir é regular" (em -uprir), não havendo menção, em verbetes desse tipo, nem mesmo à conjugação verbal. ${ }^{56}$

Para os editores, esse tipo de verbo não apresenta "particularidades flexionais", pelo que se depreende do parágrafo inicial da seção de verbos da parte pré-textual de Houaiss; Villar (2001b, p. XLIV):

Os verbos constantes desta obra trazem quase sempre no campo GRAM a remissão ao verbete de sua terminação, onde se esclarecem suas particularidades flexionais. Quando ao verbo não se seguir esta remissão, entender-se-á que não apresenta particularidades

\footnotetext{
${ }^{56}$ A indicação da conjugação a que pertencem os verbos aparece no verbete do sufixo -ar ("em que há o $a$ temático dessa conj. e o $r$ desinencial do inf.), das terminações -er ("composta da vogal temática -e-, da $2^{\mathrm{a}}$ conj., + a desin. $-r$ do inf.") e -ir ("composta da vogal temática $-i$ - da $3^{a}$ conj. $+a$ desin. $-r$ do inf. pes."), e em apenas mais 26 verbetes: -açar, -anhar, -ear, -ejar, -enhar, -entar, -estar, -iar, -inhar, -itar, -izar, -lhar, -oar, -onhar, -orar, -uçar, - ujar, -unhar e -uzar, da primeira conjugação; -ecer, -escer, -oer e -uer, da segunda, e -air, -uir, e -urir, da terceira.
} 
flexionais, conjugando-se, por conseguinte, pelos padrões regulares da respectiva conjugação, constantes dos quadros a seguir. Os verbos irregulares que constituem modelo para grande número de outros apresentam seu paradigma no próprio verbete.

Fica claro que as "particularidades flexionais" nada têm a ver com a descrição da flexão verbal vista no Capítulo 1, item 1.1.3; trata-se, aí, das características particulares aos verbos que se afastam dos "padrões regulares constantes dos quadros" - a saber: amar, vender e partir. ${ }^{57}$

Assim, um usuário interessado na conjugação dos verbos cifrar, viver ou suprir, p.ex. em cujos verbetes não há remissão para as respectivas terminações - deverá entender por si só que qualquer um desses três verbos "não apresenta particularidades flexionais, conjugando-se, por conseguinte, pelos padrões regulares da respectiva conjugação" (Houaiss; Villar, 2001b, p. XLIV).

Finalmente, a abertura dos verbetes correspondentes a verbos que seguem paradigmas diferentes representaria um aumento de 80 verbetes (60 para as terminações correspondentes a verbos que seguem dois paradigmas; oito, para as que correspondem a três paradigmas, e doze, para as correspondentes a verbos que seguem três paradigmas).

\subsection{A REDAÇÃo DO CORPO dOS VERBETES}

Aqui serão examinados os 499 verbetes que têm redação diferente da apresentada no corpo dos 182 verbetes de terminações correspondentes a verbos simplesmente classificados como regulares, a começar por aqueles onde há declaração de regularidade com descrição de particularidades morfológicas. Em seguida, virão aqueles onde há declaração de defectividade ou irregularidade, invariavelmente com descrição das particularidades morfológicas e, finalmente, aqueles onde há apenas descrição das particularidades morfológicas.

\subsubsection{DEClaraÇão de REgUlaridade COM DESCRIÇão de PARTICULARIDADES MORFOLÓGICAS}

A declaração de regularidade com descrição de particularidades morfológicas encontra-se em 431 verbetes, dentre os quais os de terminações correspondentes a verbos com particularidades sem nenhuma relação com a flexão verbal como em -ixar ("são regulares, quer o

\footnotetext{
${ }^{57}$ Em -amar, a descrição dos respectivos verbos como "regulares, mas o $a$ antenasal é vogal variável, de oral a nasalado, segundo as regiões" contraria a observação de que são "chamados verbos regulares da $1^{\text {a }}$ conjugação todos os verbos que se conjugam como o padrão ou paradigma amar" (Houaiss; Villar, 2001b, p. $\mathrm{XLV})$.
} 
$x$ valha /cs/ [...], quer valha como /ch/") e -ugnar ("regulares e preservam a seqüência consonântica -gn-: pugno (e não púguino ou puguino)").

Ainda que presentes em algumas gramáticas, conforme se viu no Capítulo 2, item 2.3.6, essas particularidades não mereceriam ter sido descritas nos verbetes de terminações verbais porque estão previstas no sistema fonológico da língua para todas as categorias gramaticais. Além disso, só quem ouve [puginu] escreverá puguino e quem diz [tru[i] no lugar de [trosi] não está livre de dizer [fi $[\mathrm{a}]$, numa variante lingüística estranha às "obras literárias, técnicas e didáticas, além de periódicos de informação geral e entretenimento" - documentos escritos que serviram de "base documental" para o dicionário (Houaiss; Villar, 2001, p. Xv). ${ }^{58}$

Embora relacionadas com a flexão verbal, também estão previstas nas regras de acentuação para qualquer classe gramatical as "adequações gráficas" dos verbos "regulares" em -inguar (“-ínguo, -ínguas, -íngua, -inguamos etc.; -íngüe, -íngües, -íngüe, -ingüemos etc.”) e -inquar ("-ínquo, -ínquas, -ínqua, -inquamos etc.; -ínqüe, -ínqües, -ínqüe, -inqüemos etc."), já que os redatores observam, em -uar, que nesses dois grupos de verbos há "ausência do hiato $u$ $a^{\prime \prime}$.

Se há ausência de hiato, há presença de ditongo e, havendo ditongo, é natural que as formas rizotônicas sejam acentuadas, ainda que, no mesmo verbete -uar, os redatores denunciem "controvérsia preceptiva quanto à acentuação nas formas rizotônicas", conforme se verá em 3.3.3.2.

Em outros verbetes, a observação das particularidades também está implícita ou explicitamente relacionada à flexão verbal, afetando sempre uma ou mais formas rizotônicas, como em:

- -airrar ("regular, preservando o ditongo ai tanto nas $\boldsymbol{f}$. rizotônicas como nas arrizotônicas"), ou -aimar ("regulares, isto é, as suas $\boldsymbol{f}$. rizotônicas ou arrizotônicas têm o ditongo ai (descendente) preservado; mas sua pronúncia é variável, de oral aberto a nasal, consoante as regiões");

- $\quad$-izar ("regulares; quando essa term. é precedida de vogal [...], o $i$ se faz graficamente acentuado nas $\boldsymbol{f}$. rizôtonicas (-aizo, -eizo, -uizo, -aize, -eize, -uíze etc.)");

\footnotetext{
${ }^{58}$ Para as terminações correspondentes a verbos com particularidades sem relação com a flexão verbal, Cf. Apêndice 3, item 3.7.
} 
- -alcar ("regulares, mas o c muda em qu antes de e (decalque, decalques, decalquemos etc.)"), ou -ulcar ("regulares, mudando o $-c$ - em $-q u$ - antes de $-e$ - desinencial (tipo inculcas, inculques)"), e

- -olar ("regulares, mas têm o -o- aberto nas f. rizotônicas: abemolo, acebolas, acrisola, assolam, cantarole, degoles, descoles, perolem"), ou -orar ("regulares, com o -o- aberto nas $\boldsymbol{f}$. rizotônicas aboboro, acaloras, afervora, clangoram, deflore, desvigores, empiore, tutorem").

Nos verbetes em que as observações dizem respeito ao comportamento dos encontros vocálicos em verbos da primeira conjugação (-airrar, -aimar e -izar), a redação nem sempre é uniforme, mas não apresenta contradições. No entanto, quando se trata da discordância gráfica (-alcar e -uçar) e da alternância vocálica (-olar e -orar) em verbos de primeira e segunda conjugações e/ou, há contradição nos quatro tipos de redação. ${ }^{59}$

Também são declarados regulares com restrição verbos com falta de regularidade em uma única forma, como em -uzir (“os vários v. da língua com essa term. são regulares, salvo na $3^{\text {a }}$ p.s. do pres.ind. e no imper.: -uz") ou no particípio, como -abrir (“o verbo abrir e seus derivados são regulares, salvo no part. aberto"), conforme se verá em 3.3.3.4 e 3.3.3.5.

Também em -apir, os redatores declaram que “o v. usucapir é regular, embora raro na $1^{a}$ p.s.pres.ind. e no pres.subj." - o que equivaleria a dizer que pode ser considerado defectivo nessas formas.

\subsubsection{REDAÇ̃̃o DOS VERBETES DE TERMINAÇÕES CORRESPONDENTES A VERBOS DE PRIMEIRA CONJUGAÇÃo COM ENCONTROS VOCÁLICOS NO INFINITIVO}

Em 27 verbetes das 56 terminações correspondentes a verbos da primeira conjugação com ditongo no infinitivo, os redatores discriminam sua particularidade principal - a preservação do encontro vocálico, como em -airrar ("preservando o ditongo ai tanto nas f. rizotônicas como nas arrizotônicas"), ou de seu timbre, como em -eimar ("mantendo sempre fechado o timbre do ditongo -ei-"). ${ }^{60}$

$$
* * *
$$

\footnotetext{
${ }^{59} \mathbf{1}^{\mathbf{0}}$ ) Na segunda conjugação, não há nenhuma terminação correspondente a verbos com encontros vocálicos no radical e, na terceira, os verbos em -air, -aurir, -ouvir e -uir não são declarados regulares. $\mathbf{2}^{\circ}$ ) Na terceira conjugação, os únicos verbos com alternância vocálica declarados regulares são os descritos em -upir.

${ }^{60}$ Consideram-se, aqui, apenas as terminações correspondentes a verbos em que ao ditongo se segue sílaba iniciada por consoante: -aiar e -uiar estão entre as terminações correspondentes a verbos simplesmente classificados como regulares; -oiar, entre as correspondentes a verbos com alternância vocálica, e -eiar, se tivesse sido estabelecida, estaria ao lado das duas primeiras (Cf. Apêndice 2, item 2.4.1).
} 
A preservação do ditongo (como em -airrar) deve ter sido descrita em virtude da formação de hiato nas formas rizotônicas de alguns poucos verbos, em:

-aidar term. o único v. da língua com esta term. é envaidar, antigo e de raro uso; as suas f. rizotônicas deviam ter sido envaído, envaídas etc., envaíde, envaídes etc., mas hoje em dia é registrado como se regular, envaido, envaidas etc., envaide, envaides etc.

-audar term. os v. da língua com essa term. são regulares, isto é, mantêm mesmo nas f. rizotônicas o ditongo au: defraudo etc., descaudas etc., fraudem etc.; mas saudar (e ressaudar) tem variação nas f. arrizotônicas ( $s a-u$-da-mos ou $s a u$-da-mos) e hiato nas rizotônicas (saúdo, saúdas, saúda, saúdam, saúde, saúdes, saúdem)

A formação de hiato em envaidar é localizada no passado e dada apenas como possível. Para saudar, conforme se viu no Capítulo 2, item 2.3.6, há tendência em fixar-se na língua popular. Por uma questão de uniformização, a preservação do ditongo deveria ter sido descrita em outros dez verbetes, onde verbos do mesmo tipo são simplesmente declarados regulares $(\text { como em -aibrar })^{61}$.

Conforme mencionado em 3.2.1, o comportamento de verbos com hiato no radical são descritos nas terminações iniciadas pelas vogais $-i$ ou $-u$ (como em -izar, por oposição a -eizar). Por isso, é equivocada a menção a essa particularidade em:

-aular term. o v. enjaular é regular e mantém em todas as f. o ditongo au já abaular, apaular, desembaular, embaular conjugam-se como saudar; ver -AUDAR

-uidar term. os v. cuidar, descuidar, recuidar são regulares; liquidar ou liqüidar são do padrão $-I D A R$, ver

-uitar term. os v. puitar e circuitar são conexos com um hiato atual (puíta) e um hiato diacrônico (cir-cu-i-tus), postulando nas f. rizotônicas igual padrão: puito, puítas, puita, puítam, puite, puites, puite, puitem; circuito, circuítas, circuita, circuitamos, circuitais, circuitam

Nesses três verbetes, deveriam ter sido descritos apenas os verbos em que há ditongo no infinitivo (enjaular e desenjaular, em -aular; cuidar, descuidar e recuidar, e também liqüidar, em -uidar, e acuitar e luitar, em -uitar).

A descrição daqueles em que há hiato no radical já figura em -ular (“se a term. é precedida de vogal [...], o -ú- se grafa acentuado nas f. rizotônicas: abaúlo, apaúlas, embaúla, faúlam [...]”), -idar (“ruidar, nas f. rizotônicas, tem acento agudo no - $i$-”) e -itar (“ajesuitar, porém, traz acento gráfico nas f. rizotônicas”), onde caberia a descrição de puitar - e circuitar e auto-circuitar, consideradas as informações dadas em -uitar. Cumpre notar que, considerada a

\footnotetext{
${ }^{61}$ Para as terminações correspondentes a verbos da primeira conjugação com ditongo no radical, Cf. Apêndice 3, item 3.8 e, para as terminações que, se estabelecidas, corresponderiam a verbos do mesmo tipo (-aibar, -eidar e-uivar), Cf. Apêndice 2, item 2.4.2.
} 
tábua de conjugação no verbete dos dois verbos, circuitar e auto-circuitar deveriam ter sido descritos em -uitar, com o ditongo preservado. ${ }^{62}$

A preservação do ditongo (como em -eimar) deve ter sido descrita em virtude da possibilidade de mudança de timbre, como em -aimar ("sua pronúncia é variável, de oral aberto a nasal, consoante as regiões"). Não havendo especificação das "regiões" onde o timbre do ditongo ai vem sendo pronunciado "de oral aberto a nasal", os verbos nessas terminações não se equiparam aos que apresentam alternância vocálica "canônica". ${ }^{63}$

Tais terminações - juntamente com as correspondentes a verbos com vogais antenasais serão identificadas, por isso, como correspondentes a verbos com alternância vocálica insuficientemente descrita.

Dentre os verbetes de terminações correspondentes a verbos com segmentos vocálicos antenasais, não há observação a respeito da suposta alternância em -onhar (“os v. da língua com essa term. são regulares"), por oposição a -omar (“os v. da língua com essa term. são regulares, mas o -o-, mesmo nas f. rizotônicas, é variável, segundo as regiões e classes, indo de aberto a nasalado") e -onar (“todos os v. da língua com essa term. são regulares, mas o -o- das f. rizotônicas varia, segundo as classes e regiões, de - $O$ - aberto a nasalado").

Nenhuma justificativa há para esse tratamento diferente: se a vogal antenasal de somar de telefonar pode abrir-se, por que não poderia abrir-se o $o$ de sonhar, como está descrito, aliás, para o $a$ em -anhar ("todos os v. da língua com essa term. são regulares, mas a vogal antenasal é variável, indo de oral a nasalada, segundo as regiões”) e -enhar (“os v. com esta term. são regulares, embora o timbre - $e$ - nas f. rizotônicas varie de aberto a fechado nasal, segundo as regiões").

A contradição no que diz respeito às formas em que poderia haver alternância denunciada pela comparação entre a redação de -omar ("mesmo nas f. rizotônicas") e -onar ("f.

\footnotetext{
${ }^{62}$ Para as terminações correspondentes parcialmente a verbos da primeira conjugação com hiato no radical, Cf. Apêndice 3, item 3.9.

${ }^{63}$ Em -eber, além da alternância vocálica "canônica" - "nas f. rizotônicas fechado o -e- na $1^{\mathrm{a}}$ p.s. do pres.ind. (percebo) e nas conexas do pres.subj. (perceba, percebas, perceba, percebam) e aberto nas restantes f. rizotônicas (percebes, percebe, percebem)" -, os redatores observam "variações mesmo cultas regionais em que estas últimas f. abertas se preservam fechadas: nas f. arrizotônicas, o - $e$ - de base tende à harmonização vocálica com a vogal tônica, constituindo, assim, uma vogal variável: percebia/percibia, mas percebemos (em Portugal faz-se - $e$ - reduzido)", sem especificar tampouco as regiões em que essas "variações" poderiam ser documentadas.
} 
rizotônicas") não é isolada, e pode ser verificada também nos verbetes de terminações correspondentes a verbos com ditongo oral. ${ }^{64}$

Em dez dos vinte verbetes de terminações correspondentes a verbos com alternância insuficientemente descrita, os redatores fazem menção, direta ou indireta, às formas rizotônicas, como em -eigar ("em certas áreas, a redução desse ditongo a -e- nas f. arrizotônicas (amantegar) gera um -e- aberto rizotônico") e -oupar ("há a tendência, em certos casos, de igualá-los aos v. em -opar, com a conseqüente conj. nas f. rizotônicas por esse padrão, não canônico").

Em sete, não fazem menção às formas em que haveria alternância (como em -anhar, visto acima) e, em três, deixam entender que o fenômeno se daria em todas as formas: em -omar (visto acima), -aimar ("as suas f. rizotônicas ou arrizotônicas têm o ditongo $a i$ (descendente) preservado; mas sua pronúncia é variável, de oral aberto a nasal, consoante as regiões") e -ainar ("preservam o ditongo ai tanto nas f. rizotônicas como nas arrizotônicas, mas seu timbre flutua de oral aberto a nasal, conforme as regiões").

\subsubsection{REDAÇÃO dOS VERBETES DE TERMINAÇÕES CORRESPONDENTES A VERBOS DE PRIMEIRA E SEGUNDA CONJUGAÇÕES COM DISCORDÂNCIA GRÁFICA E/OU ALTERNÂNCIA VOCÁLICA}

Nos verbetes de terminações correspondentes a verbos de primeira e segunda conjugações com discordância gráfica e/ou alternância vocálica, há quatro tipos de redação, como exemplificado no Quadro 3.2. ${ }^{65}$

\section{Quadro 3.2 - Principais tipos de redaÇão dos verbetes de terminações Correspondentes a Verbos COM DISCORDÂNCIA GRÁFICA OU ALTERNÂNCIA VOCÁLICA}

\begin{tabular}{|c|c|c|}
\hline tipos de redação & $\begin{array}{l}\text { terminações correspondentes a verbos } \\
\text { com discordância gráfica } \\
\end{array}$ & $\begin{array}{l}\text { terminações correspondentes a verbos com } \\
\text { alternância vocálica }\end{array}$ \\
\hline $\begin{array}{l}\text { declaração de } \\
\text { regularidade com } \\
\text { ratificação }\end{array}$ & $\begin{array}{l}\text {-igir term. os v. da língua com essa term. } \\
\text { são regulares, com a } 1^{\mathrm{a}} \text { p.s. do pres.ind. } \\
\text {-ijo (donde todo o pres.subj. -ija etc.) }\end{array}$ & $\begin{array}{l}\text {-orar term. os v. da língua com esta term., } \\
\text { orar inclusive, são regulares, com o -o- } \\
\text { aberto nas f. rizotônicas: aboboro, acaloras, } \\
\text { afervora, clangoram, deflore, desvigores, } \\
\text { empiore, tutorem }\end{array}$ \\
\hline $\begin{array}{l}\text { declaração de } \\
\text { regularidade com } \\
\text { retificação }\end{array}$ & $\begin{array}{l}\text {-acar term. todos os v. da língua assim } \\
\text { terminados são regulares, mas mudam o } \\
\text { - } c \text { - em }-q u \text { - antes de }-e \text { desinencial }\end{array}$ & $\begin{array}{l}\text {-olfar term. os v. da língua com essa term. } \\
\text { são regulares, mas com o -o- aberto nas } \mathrm{f} \text {. } \\
\text { rizotônicas: desengolfo, engolfas, golfa, } \\
\text { regolfam, solfe, desengolfes, engolfe, golfe, } \\
\text { regolfem }\end{array}$ \\
\hline
\end{tabular}

\footnotetext{
${ }^{64}$ Para as terminações correspondentes a verbos de primeira e segunda conjugações com com alternância vocálica insuficientemente descrita, Cf. Apêndice 3, item 3. 10.

${ }^{65}$ Para as terminações correspondentes a verbos de primeira e segunda conjugações exclusivamente com discordância gráfica, Cf. Apêndice 3, item 3.11; para as terminações correspondentes a verbos de primeira e segunda conjugações exclusivamente com alternância vocálica, Cf. Apêndice 3, item 3.12, e para as terminações correspondentes a verbos de primeira e segunda conjugações com discordância gráfica e alternância vocálica ao mesmo tempo, Cf. Apêndice 3, item 3.13.
} 


\begin{tabular}{|c|c|c|}
\hline $\begin{array}{l}\text { descrição de } \\
\text { particularidades } \\
\text { morfológicas }\end{array}$ & $\begin{array}{l}\text {-ercar term. os poucos } \mathrm{v} \text {. da língua com } \\
\text { essa term. têm o }-e \text { - aberto nas f. } \\
\text { rizotônicas e o }-c \text { - mudado em }-q u \text {-, } \\
\text { antes de }-e \text { - desinencial }[\ldots]\end{array}$ & $\begin{array}{l}\text {-ebar term. os poucos v. da língua com esta } \\
\text { term. têm a vogal -e-, nas f. rizotônicas, } \\
\text { aberta }[\ldots]\end{array}$ \\
\hline $\begin{array}{l}\text { descrição do } \\
\text { comportamento } \\
\text { verbal com inferência } \\
\text { de não-regularidade }\end{array}$ & $\begin{array}{l}\text {-anger term. os v. da língua com essa } \\
\text { term. têm a } 1^{\text {a }} \text { p.s. do pres.ind. -anjo } \\
\text { (com o pres.subj. conexo: tanja, tanjas } \\
\text { etc.), sendo as demais f. regulares }\end{array}$ & $\begin{array}{l}\text {-erter term. o v. verter (e seus vários der.) } \\
\text { faz a } 1^{\text {a }} \text { p.s. do pres.ind. verto, com -e- } \\
\text { fechado (donde o pres.subj. verta, com -e- } \\
\text { fechado); todas as demais f. são regulares }\end{array}$ \\
\hline
\end{tabular}

A falta de uniformidade na redação desses verbetes poderia pôr em questão a declaração de regularidade para verbos que apresentam essas particularidades - que incidem, ambas, sobre as formas rizotônicas.

Com relação à discordância gráfica, entretanto, a dúvida parece dissolver-se em Houaiss; Villar (2001b, p. XLV):

Há regularidades em certos verbos que - precisamente para serem mantidas como tais - exigem modificações ortográficas: o verbo traficar, no presente do indicativo trafico, tem de escrever-se trafique no presente do subjuntivo; fingir, finjo, finja; ficar, fico, fique; justiçar, justiço, justice; chegar, chego, chegue; distinguir, distingo, distinga, etc. $^{66}$

A alternância vocálica de primeira e segunda conjugações tem outra natureza. Não se trata de troca de grafema para manutenção da regularidade do verbo: apesar de descrita nos verbos (contestar /e/: contesto/[/) e nos nomes (posto /o/: postos / $/$ /), não é sistemática nem nos verbos (aparelhar /e/: aparelho /e/), nem nos nomes (rosto /o/: rostos /o/) - diferentemente do que ocorre com a discordância gráfica.

Houaiss; Villar (2001b, p. XLv) não falam em regularidade ou irregularidade quando tratam da alternância vocálica, limitando-se a conceituar vagamente o fenômeno:

Alternância vocálica - Dentro do sistema flexional do verbo, as formas rizotônicas tendem, porque acentuadas, a ter sua vogal diferenciada em relação às das formas arrizotônicas.

O único recurso que se tem para tentar identificar a posição dos editores com relação à alternância vocálica de primeira e segunda conjugações é verificar se um dos quatro tipos de redação prevalece no conjunto dos verbetes. Como muitos dos verbetes dizem respeito a verbos também com discordância gráfica, convém comparar todos esses dados, reunidos na Tabela 3.3.

\section{Tabela 3.3 - Distribuição dos Verbetes de terminaÇões CORReSPONDENTES A Verbos de PRimeira e SEGUNDA CONJUGAÇÕES COM DISCORDÂNCIA GRÁFICA E/OU ALTERNÂNCIA VOCÁLICA, SEGUNDO OS TIPOS DE REDAÇÃO}

\footnotetext{
${ }^{66}$ Certamente, distinga aí está em lugar de distingue.
} 


\begin{tabular}{|c|c|c|c|c|c|c|}
\hline \multirow[b]{2}{*}{ tipos de redação } & \multicolumn{2}{|c|}{ discordância } & \multicolumn{2}{|c|}{ alternância } & \multicolumn{2}{|c|}{$\begin{array}{l}\text { discordância e } \\
\text { alternância }\end{array}$} \\
\hline & $\mathrm{n}^{\mathrm{o}}$ & $\%$ & $n^{o}$ & $\%$ & $\mathrm{n}^{\mathrm{o}}$ & $\%$ \\
\hline declaração de regularidade sem restrição & 20 & 40,8 & 52 & 49,5 & 9 & 34,6 \\
\hline declaração de regularidade com restrição & 26 & 53,1 & 18 & 17,2 & 5 & 19,2 \\
\hline $\begin{array}{l}\text { descrição das particularidades morfológicas } \\
\text { sem inferência de não-regularidade }\end{array}$ & 1 & 2,0 & 29 & 27,6 & 9 & 34,6 \\
\hline $\begin{array}{l}\text { descrição das particularidades morfológicas } \\
\text { com inferência de não-regularidade }\end{array}$ & 2 & 4,1 & 6 & 5,7 & 2 & 7,7 \\
\hline $\begin{array}{l}\text { sem menção às particularidades } \\
\text { morfológicas }\end{array}$ & 0 & 0,0 & 0 & 0,0 & 1 & 3,9 \\
\hline total & 59 & 100,0 & 105 & 100,0 & 26 & 100,0 \\
\hline
\end{tabular}

Fonte: Apêndice 3, itens 3.11, 3.12 e 3.13 
É surpreendente que, nos verbetes de terminações correspondentes a verbos exclusivamente com alternância vocálica, a regularidade sem restrição (49,5\%) supere a regularidade com restrição $(17,2 \%)$, especialmente quando se verifica que, em 53,1\% dos verbetes de terminações correspondentes a verbos exclusivamente com discordância gráfica, a regularidade sofre restrição.

No entanto, com ou sem restrição, a discordância gráfica é declarada regular em 93,9\% dos verbetes - índice que cai para $66,7 \%$ no caso da alternância vocálica e 53,8\% no caso da discordância gráfica e alternância vocálica. Isso confirma que, para os editores, ambos os fenômenos são vistos como regulares, mas revela também forte tendência em não rotular a alternância vocálica como regular: em $27,6 \%$ dos verbetes de terminações correspondentes a verbos exclusivamente com alternância vocálica, há apenas descrição sem inferência de nãoregularidade (contra 5,7\%, com inferência de não-regularidade). Quando aliada à discordância gráfica, esse percentual sobe para $34,6 \%$ (contra 7,7\%).

Conforme se viu no Capítulo 2, item 2.3.3, a regularidade dos verbos de primeira e segunda conjugações com alternância vocálica é questionada por Cunha e Cintra (1985), Vázquez Cuesta; Mendes da Luz (1980) em função da feição não-regular dos verbos do mesmo tipo pertencentes à terceira conjugação.

De fato, levando-se em conta as anotações de Houaiss; Villar (2001a; 2001b) nos verbetes de terminação, se forem contabilizados os verbos de primeira e segunda conjugações com vogais médias no radical, não há dúvida de que a alternância vocálica é fenômeno regular incontestavelmente na segunda conjugação, conforme se pode ver na Tabela $3.4{ }^{67}$

\section{Tabela 3.4 - Distribuição dos Verbos de Primeira e Segunda COnJugaÇões com Vogais médias no RADICAL SEGUNDO A CLASSIFICAÇÃo}

\begin{tabular}{lcccc}
\hline \multirow{2}{*}{$\mathrm{n}^{\mathrm{o}}$ de verbos } & \multicolumn{3}{c}{$1^{\mathrm{a}}$ conjugação } & \multicolumn{2}{c}{$2^{\mathrm{a}}$ conjugação } \\
classificação & $\mathrm{n}^{\mathrm{o}}$ & $\%$ & $\mathrm{n}^{\mathrm{o}}$ & $\%$ \\
\hline sem alternância vocálica & 1704 & 37,7 & 0 & 0,0 \\
com alternância vocálica & 2806 & 62,1 & 568 & 99,3 \\
defectivos com alternância vocálica & 0 & 0,0 & 3 & 0,5 \\
defectivos & 0 & 0,0 & 1 & 0,2 \\
com indefinição & 7 & 0,2 & 0 & 0,0 \\
total & 4517 & 100 & 572 & 100 \\
Fonte: Apêndice 3, itens 3.2.14 e 3.2.15 & & & &
\end{tabular}

\footnotetext{
${ }^{67}$ Para as terminações de primeira e segunda conjugações iniciadas por -e e - $o$ com número de verbos, Cf.
} Apêndice 3.2, item 3.14 e 3.15 . 
Os três verbos de segunda conjugação que são defectivos com alternância vocálica são exceler, sobreexceler e sobrexceler, descritos em -eler ("exceler [...], para uns não tem a $1^{\text {a }}$ p.s. do pres.ind., donde, decorrentemente, não tem o pres.subj., enquanto para outros é regular (com excelo, donde excela, com -e- fechado), sendo com -e- aberto as restantes f. rizotônicas (exceles, excele, excele)"). O verbo defectivo é eqüipoler, para o qual não foi estabelecida terminação, mas que, na tábua de conjugação do verbete do verbo, recebe a seguinte observação "Forma antiga não conjugável pelos padrões atuais".

$\mathrm{Na}$ primeira conjugação, a regularidade é menos aparente: embora os verbos com alternância vocálica sejam majoritários, o percentual é muito menor do que na segunda conjugação. É preciso ressaltar, no entanto, que 1092 dos 1704 verbos sem alternância vocálica são em -ear - apenas estrear e idear sofrem alternância por abertura da vogal.

Os sete verbos em a respeito dos quais não se pode definir a existência de alternância vocálica ou não estão entre os verbos em -echar, que de acordo com o critério de Houaiss; Villar (2001a; 2001b) se dividem em:

- dez verbos (apetrechar, barbechar, bochechar, desfechar, endechar, entrechar, entrefechar, fechar, pelechar e petrechar), que por serem cognatos de substantivos em cujo verbete há indicação de timbre fechado para a vogal (apetrecho, barbecho, bochecho, desfecho, decho, entrecho, fecho, pelecho e petrecho) não sofrem alternância vocálica;

- nove verbos (amechar, aflechar, afrechar, desfrechar, encalamechar, esmechar, flechar, frechar e mechar), que por serem cognatos de substantivos em cujo verbete há indicação de timbre aberto para a vogal (flecha, frecha e mecha) sofrem alternância vocálica, e

- cinco verbos (brechar, desembrechar, embrechar, pechar e repechar), que por serem cognatos de substantivos em cujo verbete não há indicação do timbre da vogal (brecha, embrechado, embrecho e brecha e pecha) ficam sem definição.

Note-se que não tratam de invejar em -ejar ("os muitos v. da língua com esta term. são regulares, até porque o timbre fechado do - $e$ - se preserva tanto nas f. arrizotônicas quanto nas $\mathrm{f}$. rizotônicas: alveja, branquejo, desejais, espacejemos, farejamos, gorgoleje, mercadejes, pestanejam, planejemos, pragueje, rouquejeis, solfejem etc.”), que por isso não foi contabilizado entre os verbos com alternância vocálica. 
$\mathrm{Na}$ de terceira conjugação, os verbos com alternância vocálica representam uma porcentagem muito maior - o que justifica o tratamento diferente do que os redatores conferiram aos verbetes de terminações correspondentes a verbos de primeira e segunda conjugações, conforme se verá em 3.3.3.1.

\subsubsection{DECLARAÇ̃̃o DE DEFECTIVIDADE OU IRREGULARIDADE}

Em quinze verbetes, os verbos são declarados "defectivos" e, em três, "irregulares" em formas flexionadas. Esses dois tipos de verbos são conceituados no verbete:

verbo $[\ldots] \cdot$ •. defectivo GRAM verbo que não apresenta todas as formas (de tempo, pessoa, modo ou voz) do paradigma da conjugação a que pertence (p.ex.: banir, explodir, falir, comedir-se, reaver, soer, precaver-se) [A defectividade verbal tem como razões principais a eufonia e a significação.] • v. irregular GRAM verbo que não segue o paradigma dos verbos da sua conjugação, podendo a irregularidade ocorrer na desinência flexional (estou) ou no radical (troux-e) [...]

Em Houaiss; Villar (2001b, p. XLIV-LIX), os verbos defectivos são definidos em parágrafo reservado para a

Irregularidade - Os verbos que apresentam qualquer discrepância em relação ao seu paradigma são ditos irregulares. Se a irregularidade decorre do fato de que não têm certas formas - por motivo de não-uso ou de incompatibilidade de seu sentido para com certas flexões -, nesse caso tais verbos são chamados de defectivos. [...]

Nos verbetes de terminação, porém, raras vezes os verbos são declarados efetivamente defectivos, conforme se pode ver no Quadro 3.3.

Quadro 3.3 - Principais tipos de redaÇão dos verbetes de terminações correspondentes a verbos DECLARADOS DEFECTIVOS

\begin{tabular}{|c|c|c|}
\hline tipos de redação & terminações & $\begin{array}{l}\mathrm{n}^{\mathrm{o}} \mathrm{de} \\
\text { term. }\end{array}$ \\
\hline $\begin{array}{l}\text { defectivo na } 1^{\mathrm{a}} \\
\text { p.s.pres.ind. e no } \\
\text { pres.subj. }\end{array}$ & $\begin{array}{l}\text {-anquir term. o v. branquir é defectivo na } 1^{a} \text { p.s.pres.ind. e, decorrentemente, } \\
\text { no pres.subj.; por isso, não se impõe a mudança ortográfica do } q u \text { em } c \text { (que } \\
\text { ocorreria antes de } o \text { e } a \text { desinenciais) }\end{array}$ & 3 \\
\hline $\begin{array}{l}\text { tido como } \\
\text { defectivo na } 1^{\text {a }} \\
\text { p.s.pres.ind. e no } \\
\text { pres.subj. }\end{array}$ & $\begin{array}{l}\text {-amir term. os v. bramir e rebramir são tidos como defectivos, a saber, sem a } \\
\mathbf{1}^{a} \text { p.s.pres.ind. e, decorrentemente, sem o pres.subj. }\end{array}$ & \multirow[t]{2}{*}{8} \\
\hline $\begin{array}{l}\text { tido como } \\
\text { defectivo nas } \\
\text { arrizotônicas }\end{array}$ & $\begin{array}{l}\text {-agir term. os poucos v. da língua com essa term. são regulares, com o - } g \text { - } \\
\text { passando a }-j \text { - antes de }-o \text { e }-a \text { desinenciais (reajo, donde reaja etc.); vagir, } \\
\text { porém, é tido como defectivo, sem as f. que seriam com }-j-\end{array}$ & \\
\hline regularizados & $\begin{array}{l}\text {-arcir term. o v. ressarcir, tido como defectivo (na } \mathbf{1}^{a} \text { p.s.pres.ind. e, } \\
\text { decorrentemente, no pres.subj., e, antes, em todas as f. rizotonicas), é hoje em } \\
\text { dia regular (com a mudança do }-c-\text { em }-c ̧-\text { antes de }-o \text { e }-a \text { desinenciais, tipo } \\
\text { ressarço, ressarçava) }\end{array}$ & 3 \\
\hline
\end{tabular}


O predomínio de verbetes em que os verbos são tidos como defectivos é flagrantemente maior do que a dos verbos declarados defectivos. Somados aos defectivos regularizados, constituem 78,6\% do total desses verbetes. Confirma-se, aqui, mais que a resistência em rotular os verbos, a disposição em admitir que os verbos tradicionalmente considerados defectivos podem ser conjugados metaforicamente, como em -anir ("granir é regular, ganir metaforicamente tb. o é"), ou não, como em - odir ("embora us. nas $3^{\text {as }}$ p., ocorrem tb. na $2^{\text {a }}$ (com o -o- aberto no pres.ind.), havendo ocorrências de explodo (com -o- fechado) e expludo (donde, decorrentemente, exploda etc. ou expluda etc.)").

Esses dois tipos de defectividade (em uma ou nas quatro formas rizotônicas do presente do indicativo) são descritos em outros vinte verbetes, conforme se verá em 3.3.3.1.

A irregularidade, por sua vez, é declarada num número muito menor de verbetes:

- -ear ("tem irregularidade específica, a saber, nas f. rizotônicas o hiato -e-a- se desfaz em -ei-a- (ou -ei-e-), enquanto nas arrizotônicas a vogal de base rad. -e- se faz vogal variável, de pronúncia flutuante/e:i/"), onde a noção se confunde com a de coregularidade ("o padrão culto oferece extrema co-regularidade em todos os v. em causa");

- -iar ("agenciar, alumiar, apreciar, balbuciar, cadenciar, clemenciar, depreciar, desapreciar, desnegociar, despremiar, desremediar, diligenciar, evidenciar, gerenciar, incendiar, indulgenciar, mediar, premiar, presenciar, promediar, remediar, silenciar, vivenciar [...] acusam a um tempo o padrão regular de assobiar $\mathrm{e}$ o irregular de ansiar"), onde há mera descrição e outro tipo de irregularidade ("mobiliar e desmobiliar flutuam, nas f. rizotônicas, entre o acento intensivo em -biou em -li-"), e

- - uspir (“o v. cuspir (e seus der. virtuais ou potenciais) só é irregular nas f. rizotônicas do pres.ind. -ospes, -ospe, -ospem, com -o- aberto"), onde os verbos com alternância vocálica de terceira conjugação são declarados irregulares, ainda assim em determinadas formas.

É preciso notar que, em -iar, a lista dos verbos que podem ser conjugados de acordo nem sempre coincide com a dos gramáticos vista no Capítulo 2, item 2.3.4. Dos 23 verbos (um dos quais mediar, que é considerado do padrão de ansiar), há em comum apenas seis verbos: agenciar, negociar (e desnegociar), diligenciar, evidenciar, premiar, presenciar. 


\subsubsection{DESCRIÇÃo DE PARTICULARIDAdES MORFOLÓGICAS}

A maior parte destes verbetes é de terminações correspondentes a verbos com alternância vocálica de terceira conjugação e/ou defectividade, mas também a verbos com alternância de primeira e segunda conjugações (segundo o que já se viu em 3.3.1.2).

Algumas terminações correspondem a verbos com outras variações no radical do grupo do presente (do mesmo tipo das descritas em -air, -ear, e -iar, correspondentes a verbos declaradamente irregulares e/ou "co-regulares") e, especialmente, a verbos em que o $u$ é semivogal ou dígrafo (segundo o que se viu em 3.3.2).

Em número mais reduzido, há terminações correspondentes a verbos com variações de radical do grupo do presente e de tema no grupo do perfeito. Finalmente, há os verbetes onde se descrevem particularidades relacionadas com a desinência flexional.

\subsubsection{REDAÇÃo DOS VERBETES DE TERMINAÇÕES CORRESPONDENTES A VERBOS DE TERCEIRA CONJUGAÇÃo COM ALTERNÂNCIA VOCÁLICA E/OU DEFECTIVIDADE}

Com exceção de -uspir, em todos os outros verbetes de terminações correspondentes a verbos de terceira conjugação com alternância vocálica, há apenas descrição da particularidade, em geral com conjugação das formas afetadas. Muitos deles apresentam algum tipo de defectividade, de modo que as duas particularidades são descritas juntas em treze verbetes, sendo a defectividade sem alternância vocálica descrita em vinte verbetes. ${ }^{68}$

Nos verbetes de terminações correspondentes a verbos de terceira conjugação com alternância vocálica e/ou defectividade, há quatro tipos de redação, exemplificados no Quadro 3.4 .

\footnotetext{
${ }^{68}$ Para as terminações correspondentes a verbos de terceira conjugação com alternância vocálica e sem defectividade, Cf. Apêndice 3, item 3.16; para as terminações correspondentes a verbos de terceira conjugação com defectividade e sem alternância vocálica, Cf. Apêndice 3, item 3.17, e para as terminações correspondentes a verbos de terceira conjugação com alternância vocálica e defectividade, Cf. Apêndice 3, item 3.18 .
} 
Quadro 3.4 - Principais tipos de redaÇão dos verbetes de terminações correspondentes a verbos DE TERCEIRA CONJUGAÇÃo COM ALTERNÂNCIA VOCÁLICA E/OU DEFECTIVIDADE

\begin{tabular}{|c|c|c|c|}
\hline $\begin{array}{l}\text { tipos de } \\
\text { redação }\end{array}$ & com alternância vocálica & com defectividade & $\begin{array}{c}\text { com alternância vocálica e } \\
\text { defectividade }\end{array}$ \\
\hline $\begin{array}{l}\text { descrição da } \\
\text { particularidade } \\
\text { sem inferência } \\
\text { de não- } \\
\text { regularidade }\end{array}$ & $\begin{array}{l}\text {-erzir term. o v. cerzir troca } \\
\text { o -e- por - } i \text { - nas f. rizotônicas } \\
\text { (cirzo, donde cirza, cirzes, } \\
\text { cirze, cirzem) }\end{array}$ & $\begin{array}{l}\text {-alir term. os poucos } \mathrm{v} \text {. da } \\
\text { língua com essa term. (balir, } \\
\text { combalir, encalir e falir) têm } \\
\text { de regra todos as f. } \\
\text { arrizotônicas; não têm a } \\
1^{\mathrm{a}} \text { p.s.pres.ind. e logo não têm } \\
\text { o pres.subj.; há ocorrências } \\
\text { de bale, balem, combale, } \\
\text { combalem }\end{array}$ & $\begin{array}{l}\text {-ernir term. os poucos v. da } \\
\text { língua com esta term. são } \\
\text { tidos como conjugáveis só } \\
\text { nas f. arrizotônicas, com } \\
\text { tendência a admitirem as } \\
\text { rizotônicas em -ernes, -erne e } \\
\text {-ernem }\end{array}$ \\
\hline $\begin{array}{l}\text { descrição da } \\
\text { particularidade } \\
\text { com inferência } \\
\text { de não- } \\
\text { regularidade }\end{array}$ & $\begin{array}{l}\text {-ertir (4) term. os } \mathrm{v} \text {. } \\
\text { advertir e divertir fazem na } \\
1^{\mathrm{a}} \mathrm{p} . \mathrm{s} \text {. do pres.ind. -irto } \\
\text { (donde o pres. subj. -irta, irtas } \\
\text { etc.), regularizando-se nas } \\
\text { demais } f \text {., que têm -e- aberto } \\
\text { quando rizotônicas (-ertes, -erte, } \\
\text {-ertem) }\end{array}$ & $\begin{array}{l}\text {-orir term. [...] colorir, } \\
\text { descolorir, multicolorir não } \\
\text { têm a } 1^{\text {a }} \text { p.s. do pres.ind. e, } \\
\text { assim, o pres.subj., } \\
\text { regularizando-se nas demais } \\
f \text {., sendo que as rizotônicas têm } \\
\text { o-o- aberto }[. . .]\end{array}$ & $\begin{array}{l}\text {-erir term. todos os v. com } \\
\text { essa term. (alguns de uso } \\
\text { raro) fazem a } 1 \text { p.s. do } \\
\text { pres.ind. em -iro (donde o } \\
\text { pres.subj. em -ira etc.), } \\
\text { regularizando-se nas demais } \\
\text { f., que têm o -e-aberto nas f. } \\
\text { rizotônicas }\end{array}$ \\
\hline $\begin{array}{l}\text { declaração de } \\
\text { irregularidade }\end{array}$ & $\begin{array}{l}\text {-uspir term. o v. cuspir (e seus } \\
\text { der. virtuais ou potenciais) só é } \\
\text { irregular nas f. rizotônicas do } \\
\text { pres.ind. -ospes, -ospe, -ospem, } \\
\text { com -o- aberto }\end{array}$ & & \\
\hline
\end{tabular}

Apesar de ser considerada uma irregularidade que decorre da inexistência de certas formas (conforme se viu em 3.3.2), a defectividade, nos verbetes de terminação, assenta-se em terreno pantanoso, enquanto a alternância vocálica se finca em solo menos instável, conforme se pode ver na Tabela 3.5 .

\section{Tabela 3.5 - Distribuição dos VERbetes de TERMinaÇões CORRESPONDENTES A VERBos de TERCEIRA CONJUGAÇÃO COM ALTERNÂNCIA VOCÁLICA E/OU DEFECTIVIDADE SEGUNDO OS TIPOS DE REDAÇ̃̃o}

\begin{tabular}{lrrrrrr}
\hline \multicolumn{1}{r}{$\begin{array}{r}\text { terminações correspondentes } \\
\text { a verbos com }\end{array}$} & \multicolumn{2}{c}{ alternância } & \multicolumn{2}{c}{ defectividade } & \multicolumn{2}{c}{$\begin{array}{c}\text { alternância e } \\
\text { defectividade }\end{array}$} \\
tipos de redação & $\mathrm{n}^{\mathrm{o}}$ & $\%$ & $\mathrm{n}^{\mathrm{o}}$ & $\%$ & $\mathrm{n}^{\mathbf{0}}$ & $\%$ \\
descrita com inferência de não-regularidade & 19 & 95,0 & 4 & 20,0 & 6 & 42,9 \\
descrita sem inferência de não-regularidade & 0 & 0,0 & 16 & 80,0 & 8 & 57,1 \\
declarada irregular & 1 & 5,0 & 0 & 0,0 & 0 & 0,0 \\
total & 20 & 100,0 & 20 & 100,0 & 14 & 100,0 \\
\hline
\end{tabular}

Fonte: Apêndice 3.2, itens 3.2.16, 3.2.17 e 3.2.18

Em apenas 5\% dos verbetes de terminações correspondentes a verbos com alternância vocálica, os redatores declaram irregularidade, mas em 95\% deles fazem inferir a não- 
regularidade. Conforme já se viu em 3.3.1.2, nas primeira e segunda conjugações, este último percentual é muitíssimo mais baixo: 5,7\%, quando há exclusivamente alternância vocálica, e 7,7\%, quando associada à discordância gráfica. Fica evidente, portanto, que a alternância vocálica de terceira conjugação é considerada fenômeno não-regular, diferentemente do que acontece com a de primeira e segunda.

O percentual de verbetes onde a alternância vocálica sem inferência de não-regularidade $(57,1 \%)$ só é alto quando está associada à defectividade, que isoladamente apresenta um índice altíssimo (80\%). Assim, os verbos defectivos não se ligam nem à regularidade, nem à nãoregularidade: ficam a esperar pela regularização, já que a defectividade tende a ser neutralizada, quer por uma construção passiva com agente indeterminado ("tido como defectivo"), quer por uma expressão adverbial de tempo ("é hoje em dia regular").

No entanto, levando-se em conta as anotações de Houaiss; Villar (2001a; 2001b) nos verbetes de terminação, se forem contabilizados os verbos de terceira conjugação com uma das duas vogais médias do radical, a alternância vocálica parece ainda fenômeno regular, conforme se pode ver na Tabela 3.6. ${ }^{69}$

\section{Tabela 3.6 - Distribuição dos Verbos de terceira ConjugaÇão COM Vogais MÉdias e Vogal FECHADA POSTERIOR NO RADICAL SEGUNDO A CLASSIFICAÇÃO}

\begin{tabular}{lcccc}
\hline \multirow{2}{*}{\begin{tabular}{c}
\multirow{2}{*}{$\mathrm{n}^{\mathrm{o}}$ de verbos } \\
classificação
\end{tabular}} & \multicolumn{2}{c}{$\begin{array}{c}\text { vogais médias } \\
\text { le/ } / \mathrm{e} / \mathrm{o} /\end{array}$} & \multicolumn{2}{c}{ vogal fechada } \\
posterior /u/ \\
$\mathrm{n}^{\mathrm{o}}$ & $\%$ & $\mathrm{n}^{\mathrm{o}}$ & $\%$ \\
\hline sem alternância vocálica & 0 & 0,0 & 230 & 88,5 \\
com alternância vocálica & 147 & 73,8 & 19 & 7,3 \\
defectivos com alternância vocálica & 26 & 13,1 & 0 & 0,0 \\
defectivos & 26 & 13,1 & 11 & 4,2 \\
total & 199 & 100,0 & 260 & 100,0 \\
\hline
\end{tabular}

Fonte: Apêndice 3, item 3.19

Assim como ocorre nas duas outras conjugações, é majoritário o número de verbos com alternância vocálica, especialmente quando se consideram os defectivos nas formas em que são conjugados, como os descritos em -odir (“os v. da língua com essa term., embora us. nas 3 as p., ocorrem tb. na $2^{\mathrm{a}}$ (com o -o- aberto no pres.ind.), havendo ocorrências de explodo (com -ofechado) e expludo (donde, decorrentemente, exploda etc. ou expluda etc.)"): somados, esses dois

\footnotetext{
${ }^{69}$ Para as terminações de terceira conjugação iniciadas por $-e,-o$-u com número de verbos, Cf. Apêndice 3 , item 3.19 .
} 
grupos de verbos representam $86,9 \%$ de todos os verbos em terminações iniciadas por - $e$ ou por $-O$.

Nos verbos em que a vogal radical é /u/, a coisa muda de figura: os verbos com alternância vocálica (cuspir, p.ex.) e defectivos (aducir, p.ex.) - estes últimos pouquíssimo usados, aliás - estão em flagrante minoria: somados, totalizam apenas 11,5\%. Por isso, nesse caso, é possível falar em irregularidade.

Esses dados numéricos permitem confirmar a hipótese aventada no Capítulo 2, item 2.4.1, de que a defectividade está relacionada com a alternância vocálica: dos 67 verbos defectivos (quatro da segunda conjugação e 63, da terceira), 29 (três na segunda conjugação e 26, na terceira) sofrem alternância vocálica nas formas em que são conjugados.

\subsubsection{REDAÇÃO DOS VERBETES DE TERMINAÇÕES CORRESPONDENTES A VERBOS COM INSTABILIDADE NA SÍLABA TÔNICA DO RADICAL}

Verbos como aguar e argüir foram descritos, respectivamente, em -uar e -uir, mas o tratamento é indevido pois, quando o $u$ é semivogal, esses dois segmentos constituem uma única sílaba (tanto quanto -lhar). Só constituem verdadeiras terminações para verbos em que o $u$ é vogal - e, portanto sílaba vocálica -, como atuar e influir, respectivamente.

Certamente por isso, os lexicógrafos estabeleceram -aguar e outras terminações correspondentes a verbos de primeira conjugação em que o $u$ é semivogal, onde estão duplicadas, nem sempre fielmente, as informações dadas em -uar, conforme se pode ver no Quadro 3.5. 
Quadro 3.5 - Descrição MORfológica dos Verbos de PRimeira CONJUGaÇão EM QUe o $U$ É SEMIVOGaL

\begin{tabular}{|c|c|c|}
\hline \multirow{3}{*}{$\begin{array}{l}\text { descrição em -uar } \\
\text { Os v. aguar, desaguar, enxaguar, aminguar, } \\
\text { minguar, deslinguar, fraguar, embora haja } \\
\text { controvérsia preceptiva quanto à acentuação } \\
\text { nas formas rizotônicas, devem ser conjugados } \\
\text { como águo }[\ldots] ; \text { mínguo, [...] (alguns } \\
\text { gramáticos aceitam padrões como aguo [...] } \\
\text { agúe }[. . .])\end{array}$} & \multicolumn{2}{|r|}{ descrição em } \\
\hline & -aguar & $\begin{array}{l}\text { há neles controvérsia preceptiva quanto à } \\
\text { acentuação nas f. rizotônicas, mas a distinção } \\
\text { gráfica -guar de -goar visa às possibilidades da } \\
\text { silabação }(\text { a-guar [...]), donde, correlatamente, a } \\
\text { acentuação nas f. rizotônicas (águo [...]) }\end{array}$ \\
\hline & -inguar & $\begin{array}{l}\text { regulares, com as adequações gráficas: -ínguo [...] } \\
\text {-ingües }\end{array}$ \\
\hline $\begin{array}{l}\text { atreguar e eguar têm o }-u \text { - tônico nas } \mathrm{f} \text {. } \\
\text { rizotônicas }\end{array}$ & -eguar & tem o -u- tônico nas f. rizotônicas: atreguo $[\ldots]$ \\
\hline $\begin{array}{l}\text { apaniguar, apaziguar, averiguar, biguar, } \\
\text { contiguar, santiguar há também controvérsia } \\
\text { quanto a vogal que recebe a tonicidade: } \\
\text { conjugam-se, p.ex., como apaníguo ou } \\
\text { apaniguo [...] }\end{array}$ & -iguar & têm o -u- tônico nas f. rizotônicas: -iguo \\
\hline \multirow{2}{*}{$\begin{array}{l}\text { Os v. adequar, antiquar, coliquar, obliquar } \\
\text { são conjugáveis nas f. arrizotônicas }\end{array}$} & -equar & $\begin{array}{l}\text { conjugáveis, regularmente, só nas f. arrizotônicas; } \\
\text { modernamente, porém, ocorrem f. rizotônicas } \\
\text { segundo dois padrões - adéquo/adequo [...] }\end{array}$ \\
\hline & -iquar & $\begin{array}{l}\text { conjugáveis nas f. arrizotônicas; há ocorrências de } \\
\text { rizotônicas com vacilação na tônica: antiquo ou } \\
\text { antíquo }[. . .]\end{array}$ \\
\hline $\begin{array}{l}\text { em relação a alonginquar e apropinquar, } \\
\text { nas f. rizotônicas, o acento tônico é no }-i-\text { : } \\
\text { alongínquo }[. . .] \text { alongínqüe }\end{array}$ & -inquar & regulares, com as adequações gráficas: -ínquo $[\ldots]$ \\
\hline
\end{tabular}

Se as informações são coincidentes na maioria dos casos, a conjugação dos verbos em -equar e -iquar preconizada em -uar é maleabilizada nos respectivos verbetes - como acontece, aliás, para a da maioria dos verbos "tidos como defectivos". De possivelmente defectivos ("são conjugáveis nas f. arrizotônicas"), esses verbos passam a ter duas conjugações possíveis: uma em que o $u$ é semivogal (adéquo, antíquo); outra, em que é vogal (adequo, antiquo).

A mesma duplicidade de formas é descrita para aguar e derivados, anaguar e fraguar como "controvérsia preceptiva quanto à acentuação nas f. rizotônicas" mas, tanto em -aguar quanto em -uar, a escolha pela conjugação em que o $u$ é semivogal fica muito clara: "devem ser conjugados como águo" e "donde, correlatamente, a acentuação nas f. rizotônicas (águo [...])", respectivamente.

Para minguar, aminguar, deslinguar e malinguar, a duplicidade de formas é negada em -inguar, onde a regularidade é declarada para a conjugação em que o $u$ é semivogal - assim como em -inquar, como já se viu em 3.3.1 -, mostrando serem regulares os verbos que mantêm o ditongo nas formas rizotônicas do infinitivo, até porque, dentre os ditongos crescentes “apresentam estabilidade aqueles que têm a semivogal [w] precedida de [k] (grafado $q$ ) ou de [g], conforme observam Cunha e Cintra (1985, p. 48). 
Daí, provavelmente, a preferência dos lexicógrafos por águo, águas, água e águam em detrimento de aguo, aguas, agua e aguam. É possível inferir-se então que, nos verbos em -equar e -iquar, as formas em que o $u$ é semivogal são consideradas regulares, por oposição àquelas em que o $u$ é vogal, da mesma forma que as formas rizotônicas dos verbos em -eguar e -iquar são consideradas não-regulares.

Na terceira conjugação, além de ser vogal e semivogal (influir e argüir, p.ex., conforme já se viu), o $u$ pode ser também componente de dígrafo (distinguir, p.ex.). Nos dois primeiros casos, os verbos são descritos em:

-uir term os v. terminados em -uir, da $3^{\mathrm{a}}$ conj., pertencem a dois grupos: o daqueles em que o - $u$ - é foneticamente pronunciado [...] e daqueles em que o - $u$ - não é pronunciado, é mero recurso gráfico, como nos casos tratados em [...] -anguir, -anquir, -eguir, -equir, -inguir, -orquir; há três padrões que devem ser considerados na conjugação dos v. em -uir com o -u- pronunciado: 1) o dos v. construir, destruir, reconstruir, que apresentam variações de flexão, em relação ao padrão mais geral a saber: construo, construis/constróis [...] 2) o dos v. argüir, delinqüir, redargüir, com dois subpadrões (o de argüir e redargüir): arguo, argúis [...]e o de delinqüir: delínquo/delinquo, delínqües/delinqúis [...] 3) o dos demais v. (como exemplo, influir) [...]

Para os verbos em que o $u$ é semivogal, a descrição só não se repete porque não foram criadas as devidas terminações para os "dois subpadrões (o de argüir e redargüir): arguo, argúis [...] e o de delinqüir: delínquo/delinquo, delínqües/delinqúis [...]”, descritos em -uir, tendo havido omissão dos verbos desmilingüir-se (na tábua, conjugado desmilínguo-me, desmilíngüeste) e retorqüir (na tábua sem a $1^{a}$ p.s. pres.ind. e pres.subj.). ${ }^{70}$

Levando-se em conta que, na primeira conjugação, a regularidade está na preservação do ditongo nas formas rizotônicas (assim declarada em -inguar e -inquar), desmilingüir-se poderia ter sido declarado regular e retorqüir, defectivo; delinqüir é descrito com abundância nas formas rizotônicas; argüir e redargüir, com irregularidade nessas mesmas formas.

Os verbos em que o $u$ é componente de dígrafo são tratados em seus próprios verbetes: -anguir, -anquir, -eguir, -equir, -inguir e -orquir - verdadeiras terminações, nas quais o $u$ é sílaba vocálica -, mas os editores não estabeleceram terminações para moquir, mosquir, suquir e susquir, provavelmente por serem de uso restrito (nos dois primeiros há simples remissão para comer e, nos dois últimos, indicação de uso em Portugal e Trás-os Montes, respectivamente) - o que explica, mas não justifica a omissão. ${ }^{71}$

\footnotetext{
${ }^{70}$ Para as terminações que, se estabelecidas, corresponderiam a verbos de terceira conjugação em que o $u$ é semivogal, Cf. Apêndice 2, item 2.4.4.

${ }^{71}$ Para as terminações que, se estabelecidas, corresponderiam a verbos de terceira conjugação em que o $u$ é componente de dígrafo, Cf. Apêndice 2, item 2.4.5.
} 
Dos vinte verbos em que o $u$ é componente de dígrafo, distinguir e extinguir são declarados regulares, "não obstante ocorrências de hiperurbanismo com a pronúncia do -u-" (em -inguir), e seguir (e seis derivados), descrito com alternância vocálica em -eguir ("tem a $1^{\mathrm{a}} \mathrm{p} . \mathrm{s}$. do pres.ind. sigo $[\ldots]$ e as restantes f. rizotônicas com -e-aberto").

Os onze restantes apresentam algum tipo de defectividade, descrita no verbete (branquir, entanguir, extorquir, languir, ressequir e retorquir) ou mostrada na tábua de conjugação (moquir, mosquir, relinquir, suquir e susquir-se).

\subsubsection{REDAÇÃO DOS VERBETES DE TERMINAÇÕES CORRESPONDENTES A VERBOS COM OUTRAS VARIAÇÕES DE RADICAL NO GRUPO DO PRESENTE}

Diferentemente dos casos examinados em 3.3.3.1 e 3.3.3.2, nos seis verbetes seguintes, os redatores limitam-se a indicar e conjugar as formas rizotônicas que apresentam alguma particularidade, na maioria das vezes com inferência de não-regularidade:

- $\quad$-aler (“o v. valer (e seus der.) tem a $1^{\text {a }}$ p.s. do pres.ind. valho e o pres.subj. conexo valha etc.");

- -arir ("os v. malparir e parir têm nas $1^{\text {a }}$ p.s.pres.ind. malpairo e pairo e, decorrentemente, o pres.subj. malpaira e paira etc., regulares as demais $f . ")$;

- - edir (“de pedir (e derivados) e medir (e derivados) [...], com a 1"ap.s. do pres.ind. em -eço (donde pres. do subj. -eça, -eças etc.), -edes, -ede, -edem (todas essas f. com -eaberto), sendo todas as demais $f$. regulares");

- $\quad$ erder (“os v. perder e disperder fazem na $1^{\text {a }}$ p.s.pres.ind. -erco (donde todo o pres.subj. -erca, -ercas, -erca, -ercamos, -ercais, -ercam, com -e-fechado nas $\mathrm{f}$. rizotônicas) e com -e- aberto nas restantes f. rizotônicas - -erdes, -erde, -erdem; todas; todas as demais $f$. são regulares")

- $\quad$-erer ("mas requerer faz requeiro (e, decorrentemente, requeira etc.) [...]; todas as demais $f$. são regulares")

- -ouvir (“o v. ouvir e seus der. [...] fazem na 1ªp.s. do pres.ind. ouço (donde pres.subj. todo ouça, ouças etc.), regularizando-se em todas as demais $f$. .').

Mais uma vez, fica evidente a resistência à rotulação: só em -aler - provavelmente por lapso na redação - não há inferência de não-regularidade na forma primitiva e nas dela derivadas, 
cuja relação é marcada pela presença seja do adjetivo conexo (em -aler), seja dos advérbios decorrentemente (em -arir e -erer) e donde (em -edir, -erder e -ouvir).

Em -oar ("abotoar, avoar [...] têm a 1'p.s. do pres.ind. abotôo, avôo etc.") - em que a particularidade é meramente gráfica, conforme se viu no Capítulo 2, item 2.3.6 -, os verbos deveriam ter sido rotulados como regulares.

\subsubsection{REDAÇÃO DOS VERBETES DE TERMINAÇÕES CORRESPONDENTES A VERBOS COM VARIAÇÕES DE RADICAL NO GRUPO DO PRESENTE E DE TEMA NO GRUPO DO PERFEITO}

Em quatro verbetes, os redatores salientam a relação entre a "1ap.s. do pres.ind." e o "pres. subj.", conjugando as formas rizotônicas afetadas, bem como a relação entre as formas com variação de tema no grupo do perfeito, numa descrição que fica muito aquém daquela que se viu no Capítulo 1, item 1.4:

-aber term. o v. caber (e derivados) tem caibo na $1^{\mathrm{a}}$ p.s. [do pres.] ind. e o pres.subj.
conexo (caiba, caibas, caibamos etc.), e o rad. do perf. em coube (coubeste, coube,
coubemos, coubestes, couberam), com os conexos coubera etc., couber etc., coubesse
etc.; o v. saber (e derivados) tem sei na $1^{\mathrm{a}}$ p.s.ind., mas o pres.subj. saiba etc.; e o rad. do
perf. soube (soubeste, soube, soubemos, soubestes, souberam), com os conexos soubera
etc., souber etc., soubesse etc. -azer term. 1) fazer [...] tem no pres.ind. faço (donde pres.subj. faça etc.), fazes, faz, fazemos etc.; rad. do perf. fiz, fizeste, fez, fizemos etc. (donde fizera etc., fizesse etc., fizer etc.), part. feito, fut. farei etc., fut.pret. ou cond. faria etc.; 2) jazer (e adjazer, circunjazer, subjazer) é modernamente regular, salvo na $3^{a}$ p.s.pres.ind. jaz; 3) prazer [...], salvo na $3^{a}$ p.s.pres.ind. que faz praz, é regular, subsistindo, porém, no rad. do perf., a par da f. moderna regular prazi etc. (com prazera, prazesse, prazer etc.), a f. antiga prouve etc. (prouvera etc., prouvesse etc., prouver etc.); 4) trazer (destrazer, retrazer) tem no pres.ind. trago (donde todo o pres.subj. traga, tragas etc.), trazes, traz, trazemos, trazeis, trazem, perf. trouxe etc. (donde trouxera etc., trouxesse etc., trouxer etc.), fut. trarei etc. e fut.pret. ou cond. traria etc.

-izer term. o v. dizer (e seus der.) faz a $1^{\text {a }}$ p.s. do pres.ind. digo (donde o pres.subj. diga etc.), dizes, diz etc.; o perf. disse etc. (donde dissera etc., dissesse etc., disser etc.); o imp. dize ou diz, diga, dizei, e o part. dito

-oder term. o v. poder [...] faz a $1^{\mathrm{a}} \mathrm{p} . \mathrm{s}$. do pres.ind. posso (donde o pres.subj. possa etc.), podes, pode, podem (com -o- aberto); perf. pude, pudeste, pôde (com acento gráfico fechado), pudemos, pudestes, puderam (com -e- desinencial aberto) (donde pudera etc., pudesse etc. e puder com -e- sempre aberto); as demais f. são regulares

Em -aber, quando observam que "o v. saber (e derivados) tem sei na $1^{\mathrm{a}}$ p.s.ind., mas o pres.subj. saiba etc.", questionam a relação entre forma primitiva e formas derivadas, sem mostrar, no entanto, que, em sei, há alternância na vogal radical e perda da consoante final.

Em -azer e -izer, a conjugação mecânica não permite ver que $f a z$ e traz, de um lado, e diz, de outro, são formas reduzidas do radical sem adição da vogal temática, de acordo com uma regra morfofonêmica vista no Capítulo 1, item 1.1.3 - provavelmente não-regulares, a julgar pelo 
tratamento dado a jazer ("é modernamente regular, salvo na $3^{a}$ p.s.pres.ind. jaz) e prazer ("salvo na $3^{\text {a }}$ p.s.pres.ind. que faz praz, é regular"), semelhante ao que recebem os verbos em -uzir, declarado regular "salvo na $3^{a}$ p.s. do pres.ind. e no imper.: -uz".

Também passam despercebidas na conjugação verbal a "alternância /i/-/e/" em fiz e $f e z$ e a variação no radical no futuro do presente e do pretérito em fazer e trazer, não havendo em -izer nem mesmo a conjugação dessas duas formas.

Em -oder, os redatores chamam atenção para a alternância vocálica nas formas rizotônicas (“com -o- aberto"), mas não para a "alternância /u/-/o/", em pude e pôde (com $o$ fechado, e não com "acento gráfico fechado"), que só é graficamente acentuada por oposição a pode (com o aberto). Cumpre notar que a vogal temática (e não o "-e-desinencial”) é aberta no radical do perfeito não só em puderam (e "pudera etc., pudesse etc. e puder"), mas também nos verbos com variação de tema no grupo do perfeito - onde os redatores não fizeram o mesmo tipo de observação.

Em outros dois verbetes, os redatores salientam apenas a relação entre as formas com variação de radical no grupo do perfeito:

-aver. term. o v. haver faz no pres.ind. hei, hás, há, havemos ou hemos, haveis ou heis, hão; o pres.subj. haja etc.; o rad. do perf. houve, donde houvera etc., houvesse etc., houver etc., sendo regulares as demais f.; o v. reaver, daquele der., só se conjuga nas $\mathrm{f}$. em que haver apresenta a letra $v$ (reouve etc., inclusive); já precaver (e desprecaver) só se conjuga nas f. arrizotônicas

-estar term. [...] estar, do lat. sto, as, stěti, stātum, stāre 'estar de pé, estar a servir (à mesa), estar à espera', conjuga-se estou, ás, á, amos, ais, ão; estava etc.; estive etc. (donde estivera etc.; estiver etc.; estivesse etc.); estarei etc.; estaria etc.; estado; estando e assim os dois der. sobestar, sobreestar/sobrestar, que se conjugam igualmente [...]

Em -aver, não sugerem relação entre hei e a variação haj, pela vocalização da consoante final e uma alternância /a/-/e/ - descrição muito próxima da de sei/saiba e de estou/esteja, ainda que, em -estar, o presente do subjuntivo não seja nem mesmo conjugado.

Além disso, a conjugação mecânica obscurece a variação de radical em hemos e heis, e sobretudo em hás, há, hão, em -aver, e a alternância /i/-/e/ em estive e esteve, em -estar, da mesma forma que em -azer.

Finalmente em -erer, ocupam-se apenas do presente do indicativo de querer (além de requerer, conforme se viu em 3.3.3.3), tratando da alternância vocálica como fenômeno nãoregular e questionando a relação entre forma primitiva e derivada da mesma forma como fazem para saber, em -aber: 
-erer term. o v. querer e seus der. [...] se conjugam: $1^{\mathrm{a}}$ p.s.pres.ind. quero, com -eaberto (embora o pres.subj. todo seja queira, queiras etc.) [...]; as demais f. rizotônicas são com -e- aberto: queres, quer (ou quere), querem; todas as demais $f$. são regulares, salvo o part. dúplice de bem-querer e malquerer, bem-querido e benquisto, malquerido e malquisto

Salientam a existência de uma variante quere - característica do português europeu Cunha; Cintra (1985, p. 420), deixando de chamar atenção para a forma quer, que não recebe vogal temática tanto quanto dos verbos em -zer e -zir.

\subsubsection{REDAÇ̃̃O DOS VERBETES COM OBSERVAÇÕES ESTRANHAS À MORFOLOGIA VERBAL}

Os redatores fazem menção à morfologia verbal em praticamente todos os verbetes de terminação, mas em um número muito reduzido de verbetes, constam também informações estranhas à conjugação verbal. Em onze deles, há referência ao valor aspectual dos verbos: "v. ditos causativos" (em -entar), "aspectualmente freqüentativos, iterativos, afetivos" (em -ejar) e “ incoativo"(em -escer). ${ }^{72}$

Nas onze terminações restantes, salientam-se particularidades de verbos isolados no interior de seu próprio verbete, como em -elir ("com relação a delir, cumpre considerar que Amador Arrais usa da f. dile na $3^{\text {a }}$ p.s. do pres.ind., que presume o paradigma dilo, diles, dile, delimos, delis, dilem, pres.subj. dila, dilas etc., no sXVII"). ${ }^{73}$

\subsection{Considerações finais}

A falta de uniformização na terminologia, no estabelecimento de verbetes e na redação do corpo dos verbetes denuncia lapsos na edição e redação que, embora perfeitamente compreensíveis em obras desse porte, comprometem a descrição da morfologia verbal do português na forma de verbetes de terminação - que, mais que tudo, não se revelou econômica.

O objetivo de "possibilitar a identificação dos padrões de alteração gráficos, históricos, semânticos e/ou morfológicos ocorridos em cada grupo citado" não foi alcançado. Pelo contrário, a descrição dos verbos que constam nas listas alfabéticas dos verbos irregulares nas gramáticas

\footnotetext{
${ }^{72} \mathbf{1}^{\text {a) }}$ São descritos também como freqüentativos os verbos em -açar, -ejar, -inhar, -itar e -izar; como incoativos, os verbos em-escer. $\mathbf{2}^{\circ}$ ) Em -iscar, os redatores assinalam "a noção verb. diminutiva ou afetiva" (em) e, em -lhar, "a noção de dim. (ou, polarmente, aum.)" - que estão associadas ao aspecto em Borba (1976, verbete aspecto), quando fala em "aspecto diminutivo", e Câmara Jr. (1968, verbete aspecto), quando fala em "iterativo a que se acrescenta um grau diminutivo".

${ }^{73}$ Para os verbetes de terminações que incluem observações estranhas à conjugação verbal, Cf.Apêndice 3.2, item 3.2.20.
} 
foi atomizada em alguns verbetes isolados - um evidente retrocesso em relação à organização dos verbos em padrões especiais, tal como estabelecidos por Mattoso Câmara Jr.

No entanto, desconsiderando a análise mórfica da estrutura verbal proposta por Mattoso Câmara Jr., desligando a vogal temática do radical e ligando-a ao sufixo flexional, os lexicógrafos só poderiam reproduzir a solução simplista de alguns manuais de conjugação verbal e algumas gramáticas voltadas para falantes de português como língua estrangeira.

Com isso, fenômenos gráficos irrelevantes para a conjugação verbal ganham importância e são descritos, p.ex., em verbetes de terminações correspondentes a verbos com discordância gráfica - tão dispensáveis quanto os de terminações correspondentes a verbos sem nenhuma particularidade ou de terminações de baixa ocorrência.

É assim que se perde de vista a divisão dos verbos em três grandes grupos, conforme terminados em -ar, -er ou -ir, que podem ser reduzidos a dois, consideradas as semelhanças na estrutura verbal dos verbos da segunda e da terceira conjugações. Não é à toa, portanto, que a indicação da conjugação a que pertencem os verbos aparece marginalmente em menos de trinta verbetes de terminação.

No entanto, o levantamento das terminações correspondentes a verbos com alternância vocálica permitiu que fosse feita, neste trabalho, uma comparação entre o número de verbos das três conjugações com vogais orais médias no radical com e sem alternância vocálica, e também entre o número de verbos da terceira conjugação com vogal nasal fechada anterior e oral fechada posterior com e sem alternância vocálica.

Comparados esses dados, constatou-se que a maioria dos verbos com vogais orais médias no radical na primeira e terceira conjugação - e a totalidade na segunda conjugação - sofre alternância vocálica. Por serem maioria, dentro de sues respectivos padrões especiais, os verbos com alternância vocálica podem ser descritos dentre os regulares.

Com relação à conjugação dos verbos em -guar/-quar e -güir/-qüir, os lexicógrafos reproduzem aquilo que se constatou no Capítulo 2, nem sempre em consonância com Rodrigues (2003), responsável pelas tábuas de conjugação do dicionário. A “babel”, a que se refere Aguiar (1955), instalada na conjugação dos verbos em " $g$ e $q+$-uar", só poderá ser desfeita com base numa pesquisa de uso desses verbos por falantes de português como língua materna. ${ }^{74}$

${ }^{74}$ Exemplos extraídos de um mesmo texto em site da Internet mostram, p.ex., a hesitação em relação ao valor (vocálico ou semivocálico) do $u$ em argüir: "Informando que o BNB já está recebendo como incentivo e não como imposto as diferenças da correção monetária [...] argúem em sua inicial que [...] gozam do benefício do reinvestimento de $40 \%$ do valor do imposto devido [...]" e, mais adiante, "As informações da 
Deve-se esperar o mesmo no que toca aos verbos em -iar que seguem dois padrões, pois cada autor propõe uma lista diferente - o que põe em cheque a descrição até mesmo dos verbos que recebem a mesma classificação.

Receita Federam árgüem em preliminar a decadência do direito à impetração [...]” (http:// www.trf5.gov.br/gabinete_revistaphp, 19/12/2006, 17:43). 


\section{SíNTESE DAS CONSIDERAÇõES FINAIS}

Ao final deste estudo, salienta-se a importância de entender a língua como um sistema feito de unidades que se distribuem segundo critérios reconhecíveis por meio da comparação entre as formas. Assim, não se pode prescindir da descrição criteriosa, deixando-se de lado especulações que não vão além da intuição que todo falante tem ao usar a língua.

Sem esquecer outras descrições da morfologia verbal em português (Luft, 1976; Pontes, 1972) e considerando-se a possibilidade de haver outros estudos sobre o tema aos quais não se tenha tido acesso aqui, não resta dúvida de que a análise mórfica proposta pelo autor contribui enormemente para a compreensão da estrutura verbal em português e, portanto, para a fixação das formas verbais, por parte dos falantes de português como língua materna ou estrangeira.

Também é indiscutível a viabilidade de aplicação da descrição de Câmara Jr. (1975, 1972, 1970), comprovada especialmente na exposição feita por Bechara (1999; 1975). Com a reorganização dos morfemas da estrutura verbal em quadros, evidenciando-se graficamente os morfemas verbais - com faz também Luft (2000) -, foi possível identificá-los mais facilmente do que na forma como estão expostos pelo próprio lingüista e por Bechara $(1999 ; 1975)$.

Não tivesse o lingüista brasileiro identificado os morfemas do verbo por meio da comparação de seus alomorfes nos diferentes modos e tempos e nas diferentes pessoas, estabelecendo um padrão geral, facilmente identificável nas três conjugações, guardadas as especificidades de cada uma delas, com relação mais estreita entre as duas primeiras.

Nestas, também é flagrante a identidade no que toca aos morfemas característicos da alternância vocálica (/e/-/ع/, nos verbos com radical grafada $e$, e /o/-/[//, em todas as formas, e nos verbos com radical grafada $o$, em todas as formas), que também estão sujeitos à alternância na terceira, na qual, entretanto, verbos com outras vogais radicais também sofrem alternância (/o/-

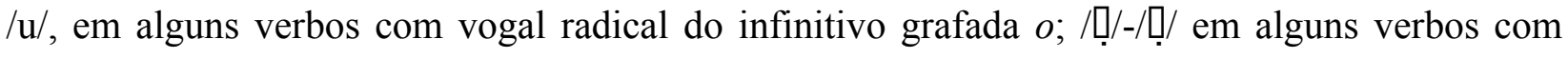
vogal do infinitivo grafada en, descontados, aqui, os casos isolados, como de frigir).

O levantamento quantitativo dos verbos com essas vogais no radical do infinitivo, em Houaiss; Villar (2001a; 2001b), mostrou preponderância da alternância na primeira conjugação 
(62,1\%), ainda mais significativa segunda $(99,3 \%)$ e nos verbos de terceira conjugação com vogais médias no radical $(73,8 \%)$. Esses percentuais fazem ver, nos padrões da alternância vocálica em português, desvios mais significativos na primeira e na terceira conjugações.

A comparação da classificação dos verbos defectivos levantados em gramáticas (Bechara, 1999; Cunha; Cintra, 1985) e manuais de conjugação (Rodrigues, 2003; Lopes, 1992; Ryan, 1991) deram relevância à hipótese de Said Ali (1931), de que a dúvida a respeito da mudança no timbre da vogal pode fazer que o falante hesite entre duas formas, chegando mesmo a evitá-las para não incorrer em erro.

A falta de coincidência entre a classificação dos defectivos que fazem os autores e de gramáticas e manuais de conjugação verbal - assim como em Houaiss; Villar, 2001a; 2001b - faz ver que a descrição (muitas vezes contraditória) oferecida nessas obras de referência não pode ser tomada como norma, especialmente no caso de certos verbos que, no uso, vêm perdendo a defectividade.

Este estudo aponta, ainda, para a necessidade de pesquisa de uso não só dos verbos defectivos, mas também de grupos de verbos cuja conjugação não está bem estabelecida nas gramáticas, manuais de verbos e dicionário consultado (verbos em -iar com duplicidade de formas, verbos em o $u$ pode ser considerado vogal ou semivogal). Exemplos extraídos de sites da Internet - como os que foram transcritos neste estudo - são apenas indicadores da instabilidade no uso, mas não podem ser considerados fonte única: impõe-se a organização de um corpus estabelecido em textos de língua escrita e oral produzidos por usuários da língua comprovadamente escolarizados.

Retomam-se, aqui, algumas constatações referentes à forma de exposição da matéria nos três tipos de obras de referência. Nos estudos de Joaquim Mattoso Câmara Jr., ficam evidentes problemas de redação que poderiam ter sido solucionados pelo estabelecimento do texto por parte de especialistas em lingüística - iniciativa que os editores ainda estão a dever ao lingüista.

O mesmo vale para a excelente gramática de Evanildo Bechara, que com uma edição de texto, acompanhada pelo autor, ofereceria igual facilidade à que oferece a gramática Celso Cunha e Lindley Cintra, na consulta por parte de usuários não especializados em estudos lingüísticos e gramaticais. Dentre as gramáticas voltadas para falantes de português como língua estrangeira, destaca-se a exposição de Eberhard Gärtner, Paul Teyssier, e Pilar Vázquez Cuestas e Maria Albertina Mendez da Luz. Apesar de alguns problemas de conteúdo isolados, também merece 
menção a gramática de Amélia Hutchinson e Janet Lloyd, que tiveram êxito na sua tentativa de facilitar a consulta para fins didáticos.

A comparação da redação dos verbetes de terminações verbais do Dicionário Houaiss da língua portuguesa também revela a necessidade de refinamento na edição de texto, ainda que se reconheça a dificuldade de concretização de um trabalho desse porte, que é demorado e, muitas vezes, inviabiliza a comercialização da obra. É flagrante a falta de economia na descrição da morfologia verbal em pouco menos de seiscentos verbetes, mas é preciso reconhecer que, sem o estabelecimento desses verbetes, muitas das constatações feitas neste estudo não teriam sido possíveis.

Finalmente, a título de proposta a ser ainda posta em prática, apresenta-se, no Apêndice 4, uma tentativa de tornar aparente, para os falantes de português como língua estrangeira, a distribuição dos morfemas verbais em português, sem necessidade de submetê-los à repetição exaustiva, quando da memorização das formas verbais do português. 


\section{REFERÊNCIAS}

Abreu M. H. e Murteira M. R. Grammatica del portoghese moderno.Teoria. Esercizi. Norma europea. Norma brasiliana. Bologna: Zanichelli / Porto Editora, 1998

Academia Brasileira de Letras. Volp - Vocabulário ortográfico da língua portuguesa. 2.ed. Rio de Janeiro: A Academia, 1998

Aguiar, M. Notas de português de Felinto e Odorico. Transcrição e comentário. Rio de Janeiro: Organização Seimões, 1955

Allen Jr., J. H. D. Portughese Word-formation with Suffixes. In: Language. Journal of the Linguistic Society of America. New York: Kraus, 1966, v. 17, n² 2, 1941

Bechara, E. Moderna gramática portuguesa. 37. ed. rev. e ampl. Rio de Janeiro: Lucerna, 1999 1975 . Moderna gramática portuguesa. Cursos de $1^{\circ}$ e $2^{\circ}$ Graus. 19. ed. São Paulo: Nacional,

Benveniste, C. Problèmes de linguistique générale. 4.ed. rev. e corr. Paris: Gallimard, 1966

Bisol, L. A sílaba e seus constituintes. In: Neves, M. H. M. Gramática do português falado (Org.). 2.ed. São Paulo / Campinas: Humanitas / Ed. Unicamp, 1999. v.7, p. 701-39

Borba, F. S. Dicionário de usos do português do Brasil. São Paulo: Ática, 2002. Colaboradores: Sebastião Expedito Ignácio, Maria Helena de Moura Neves, Beatriz Nunes de Oliveira, Marina Bortolotti Bazzoli, Maria Celeste Consolim Dezotti . Uma gramática de valências para o português. São Paulo: Ática, 1996 (Coord.). Dicionário gramatical de verbos do português contemporâneo do Brasil.. São

Paulo: Edunesp, 1990 . Pequeno vocabulário de lingüística moderna. 2.ed. rev. e aum. São Paulo: Nacional, 1976

Câmara Jr., J. M. A alternância portuguesa "fui : foi". In: Confluência. Revista do Instituto de Língua Portuguesa. Rio de Janeiro: Liceu Literário Português, 2004, n. 27 e 28, p. 277-85 . Para o estudo da fonêmica portuguesa. 2.ed. prep. por Raimundo Barbadinho Neto conforme indicações deixadas pelo Autor. Rio de Janeiro: Padrão, 1977 . História e estrutura da língua portuguesa. Rio de Janeiro: Padrão, 1975 . Princípios de lingüística geral. 4.ed. rev. e aum. Rio de Janeiro: Acadêmica, 1974 . Dispersos de J. Mattoso Câmara Jr. Rio de Janeiro: FGV, 1972 . Estrutura da língua portuguesa. Petrópolis: Vozes, 1970 . Problemas de lingüística descritiva. Petrópolis: Vozes, 1969 . Dicionário de filologia e gramática. 3.ed. rev. e aum. São Paulo: J. Ozon, 1968

Carone, F. B. Morfossintaxe. São Paulo: Ática, 1989. Série Fundamentos

Cunha e Cintra, L. Nova gramática do português contemporâneo. 2. ed. Rio de Janeiro: Nova Fronteira, 1985 
Eastlack, C. L. The morphology of the Verb in Portuguese. Dissertation presented to the Faculty of the Graduate School of the University of Texas in Partial Fulfillment of the Requirements for the Degree of Doctor of Philosophy, 1964

Fernández, Salvador. Gramática española. Los sonidos. El nombre y el pronombre. Madrid: Manuales de la Revista de Occidente, 1951

Gärtner, E. Grammatik der portugiesischen Sprache. Tübingen: Niemeyer, 1998a . Uma nova gramática do português para alemães. In: Revista portuguesa de Filologia.

Cimbra: Faculdade de letras da Universidade de Coimbra, 1988b, v. xxII, P. 1-24

Giurescu, A. Une classification des verbes portugais. In: Revue Roumaine de Linguistique.

Bucareste: Editura Academiei Republicei Socialiste România. tomo XXI, nº 4, 1976, p. 483-9

Gleason, H. A. Introduction to Descriptive Linguistics. New York: Holt, Rinehart and Winston, 1961

Hockett, C. F. A Course in Modern Linguistics. 12.ed. New York: Macmillan, 1967

Houaiss, A. e Villar, M. S. Dicionário eletrônico Houaiss da língua portuguesa. Versão 1.0. Rio de Janeiro: Objetiva, 2001a . Dicionário Houaiss da língua portuguesa. Rio de Janeiro: Objetiva, 2001b

Hutchinson, A.; Lloyd, J. Portuguese. An Essential Grammar. London/ New York: Routledge, 2002

IPA. The International Phonetic Alphabet. 2005 www.arts.gla.ac.uk/IPA/ipa.html

Kehdi, V. A morfologia e a sintaxe portuguesas na obra de J. Mattoso Câmara Jr. Tese de livredocência apresentada ao DLCV da FFLCH - USP, 1998

. Formação de palavras em português. São Paulo: Ática, 1992

. Morfemas do português. São Paulo: Ática, 1990

Kury, A.G. Pequena gramática. Para a explicação da Nova Nomenclatura Gramatical. Rio de Janeiro: Agir, 1959

Le nouveau Bescherelle. L'art de conjuguer. Dictionnaire des huit mille verbes usuels. Paris: Hatier, 1966

Lopes, João Antunes. Dicionário de verbos conjugados. 3.ed. Porto: Lello \& Irmão, 1992

Luft, Celso Pedro. Moderna gramática brasileira. Porto Alegre: Globo, 2000

. Gramática resumida. Explicação da Nomenclatura Gramatical Brasileira. Porto Alegre:

Globo, 1978

. Para uma análise morfológica do verbo português. Dissertação para concurso de livredocência de língua portuguesa na UFRS. Porto Alegre, 1976

Lyons, J. Introdução à lingüística teórica. 2. ed. São Paulo: Nacional/Edusp, 1979

Marouzeau, J. Léxique de la terminologie linguistique. Français, allemand, anglais. 2. ed. Paris: Paul Geuthner, 1943 
Masip, V. Gramática de português como língua estrangeira. Fonologia, ortografia e morfossintaxe. São Paulo: EPU, 2000

Nogueira, R. S. Dicionário de verbos portugueses conjugados. 3.ed. Lisboa: Livr. Clássica Edit, 1963

Oliveira, José Luís de. Interpretação da "Nomenclatura gramatical brasileira". Rio de Janeiro: Biblioteca do Exército, 1965

Pagliarini, M. I. Morfofonologia das formas verbais finitas. Dissertação submetida à UFSC para obtenção do grau de mestre em Letras, área de Lingüística, 1978

Perini, M. A. Modern Portuguese. A reference Grammar. New Haven/ London: Yale University Press, 2002

Pontes, E. Estrutura do verbo no português coloquial. Petrópolis: Vozes, 1972

Rodrigues, V. C. Dicionário Houaiss de verbos da língua portuguesa. Conjugação e uso de preposições.São Paulo: Objetiva, 2003

Ryan, M. A.. Conjugação dos verbos em português: prático e eficiente. 8. ed. São Paulo: Ática, 1991

Said Ali, M. Grammatica historica da lingua portugueza. 2. ed. melh. e aum. de lexicologia e formação de palavras e syntaxe do português histórico. São Paulo: Melhoramentos, 1931

Santos, P. M. R. A defectividade verbal em português. Dissertação de mestrado em língua portuguesa apresentada à coordenação dos cursos de oós-graduação em Letras da UFRJ

Teyssier, P. Manuel de langue portugaise Portugal-Brésil. Paris: Klincksieck, 1976

Vázquez Cuesta, P. e Mendes da Luz, M. A. Gramática da língua portuguesa. São Paulo: Martins Fontes, 1980

Zanotto, N. Estrutura mórfica da língua portuguesa. 2.ed. Caxias do Sul: Educs, 1991 


\section{APÊNDICE 1}

\section{Plano de exposição da morfologia Verbal nas obras nas obras examinadas no Capítulo 2}

Neste Apêndice, está transcito o índice da seção sobre a morfologia verbal das obras consultadas na seguinte ordem:

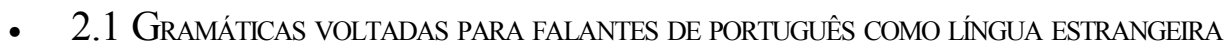

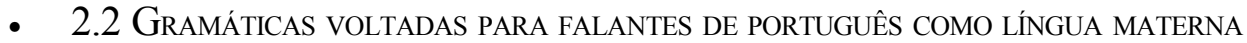

- $\quad$ 2.3 Manuais de CONJUGaÇÃo

\subsection{Gramáticas voltadas PaRa Falantes de PORTUGUÊS COMO Língua ESTANGEIRA}

No capítulo 6 (“Il verbo"), Abreu; Murteira (1998: 61-152, 189-219, E 137-74) tratam paralelamente da morfologia e do uso das formas verbais. Além disso, há seis tábuas de conjugação verbal ("Tavole schematiche" - TS) e onze séries de exercícios ("Ezercizi Norma europea") apenas sobre morfologia verbal.

6.1 Tempi e modi del verbo

6.1.1 Il numero e le persone

6.1.2 Il modo

6.1.3 Il tempo

6.1.4 La voce

6.1.5 L'aspetto

6.2 I verbi ausiliari

6.3 Le voci

6.4 Le coniugazioni dei verbi regolari

6.5 L'indicativo

6.5.1 Usi dell'indicativo

6.6 I tempi dell'indicativo

6.6.1 Presente

6.6.2 Imperfetto

6.6.3 Perfetto semplice

6.6.4 Piuccheperfetto semplice

6.6.5 Piuccheperfetto composto 
6.6.6 Pretérito perfeito composto ${ }^{75}$

6.6.7 Futuro semplice

6.6.8 Futuro composto

6.6.9 Condizionale semplice

6.6.10 Condizionale composto

$6.7 \mathrm{Il}$ congiuntivo

6.7.1 Usi del congiuntivo nelle proposizioni principali

6.7.2 Usi del congiuntivo nelle proposizioni subordinate

6.8 I tempi del congiuntivo

6.8.1 Presente del congiuntivo

6.8.2 Imperfetto del congiuntivo

6.8.3 Perfetto del congiuntivo

6.8.4 Piuccheperfetto del congiuntivo

6.8.5 Futuro semplice del congiuntivo

6.8.6 Futuro composto del congiuntivo

6.9 L'imperativo

6.9.1 Le forme dell'imperativo

6.9.2 La coniugazione completa

6.9.3 L'imperativo negativo

6.9.4 Verbi que hanno l'imperativo irregolare

6.9.5 Uso dell'imperativo

6.10 Le forme nominale

6.10.1 L'infinito

6.10.2 Il participio passato

6.10 .3 Il gerundio

6.11 Particolarità della flessione di alcuni verbi

6.11.1 Verbi com irregolarità grafica

6.11.2 Verbi com alternanza grafica

6.11.3 Altri tipi di irregolarità

6.12 I vallori aspettuali delle perifrasi verbali

6.12.1 Inizio dell'azione

6.12.2 Durata dell'azione

6.12.3 Fine dell'azione

6.12.4 Azione rimasta inconclusa

6.12.5 Ripitizione dell'azione

6.12.6 Altre perifrasi verbali

TS 1 Coniugazione dei verbi ausiliari

TS 2 Coniugazione dei verbi regolari

TS 3 Coniugazione pronominale

TS 4 Coniugazione della voce passiva

TS 5 Coniugazione dei principali verbi irregolari

TS 5 Haver

E11 La coniugazione verbale

11.1 I verbi regolari - Indicativo

11.2 I verbi regolari - Congiuntivo

11.3 I verbi irregolari - Indicativo

11.4 I verbi ausiliari - Indicativo

11.5 I verbi irregolari e ausiliari- Congiuntivo

${ }^{75}$ Certamente por lapso de edição, o título aparece em português, e não em italiano. 
11.8 I verbi com irregolarità grafiche

11.9 I verbi com alternanza vocalica

11.10 L'imperativo e le forme nominali

Gärtner (1998, p. 19-77) expõe a morfologia verbal na primeira seção 1.1 (“Das Verb”) do capítulo sobre o predicado ("Das Prädikat").

1.1.1 Die grammatischen Kategorien des Verbs

1.1.1.1 Person und Numerus

1.1.1.2 Die Tempora

1.1.1.3 Die Modi

1.1.1.4 Die Verbalperiphrasen

1.1.1.5 Das passiv - A voz passiva

1.1.2 Das Formensystem des Verbs

1.1.2.1 Ableitung der regelmässigen Verbformen

1.1.2.2 Übersicht über die Konjugation der regelmässigen Verben

1.1.2.2.1 Einfache Formen des Aktivs

1.1.2.2.1.1 Indikativ - Indicativo

1.1.2.2.1.2 Konjunktiv - Conjuntivo

1.1.2.2.1.3 Konditional - Condicional

1.1.2.2.1.4 Imperativ - Imperativo

1.1.2.2.1.5 Nominalformen - Formas Nominais

1.1.2.2.2 Zuzammengesetzte Formen des Aktivs

1.1.2.2.2.1 Indikativ - Indicativo

1.1.2.2.2.2 Konjunktiv - Conjuntivo

1.1.2.2.2.3 Konditional - Condicional

1.1.2.2.2.4 Nominalformen - Formas Nominais

1.1.2.2.3 Die Formen des objektbezogenen Vorgangspassivs

1.1.2.2.3.1 Indikativ - Indicativo

1.1.2.2.3.2 Konjunktiv - Conjuntivo

1.1.2.2.3.3 Konditional - Condicional

1.1.2.2.1.4 Nominalformen - Formas Nominais

1.1.2.3 Besonderheiten der Formenbildung

1.1.2.3.1 Orthographische Veränderungen

1.1.2.3.2 Besonderheiten des Presente do Indicativo und des Presente do Conjuntivo

1.1.2.3.2.1 Betonungswechsel uns Akzentsetzung

1.1.2.3.2.2 Vokalwechsel - Alternância vocálica

1.1.2.3.2.3 Verben mit stammauslautendem Vokal

1.1.2.3.2.4 Veränderungen des stammauslautendem Konsonanten

1.1.2.3.2.5 Endungsausfall bei Verben auf -zer, -zir und -erer

1.1.2.3.3 Besonderheiten der Perfekstammes

1.1.2.3.3.1 Betonung und Akzentsetzung

1.1.2.3.3.2 Das Pretérito perfeito simples des unregelmässigen Verben

1.1.2.3.3.3 Besonderheiten des Pretérito mais-que-perfeito simples, des Pretérito imperfeito do Conjuntivo und des Futuro do Conjuntivo

1.1.2.3.4 Besonderheiten des Pretérito imperfeito

1.1.2.3.5 Besonderheiten des Futuro

1.1.2.3.6 Besonderheiten der Bildung des Particípio (do pretérito)

1.1.2.3.6.1 Verben mit einem unregelmässigen Partizip ${ }^{76}$

1.1.2.3.6.1 Verben mit doppeltem Partizip ${ }^{77}$

1.1.2.4 Unregelmässige Verben

\footnotetext{
${ }^{76}$ Certamente Partizip está no lugar de particípio.
}

${ }^{77}$ Certamente Partizip está no lugar de particípio. 
Hutchinson; Lloyd (2002, p. 54-81) tratam da morfologia juntamente com o uso das formas no capítulo 7 ("Verbs").

7.1 MoOds AND TENSES

7.2 IndiCATIVE MOOD

7.2.1 Present

7.2.1.1 Meanings

7.2.1.2 Conjugation

7.2.1.3 Irregular Present

7.2.2 Present Perfect

7.2.2.1 Meanings

7.2.2.2 Conjugation

7.2.3 Imperfect

7.2.3.1 Meanings

7.2.3.2 Conjugation

7.2.3.3 Irregular Imperfect

7.2.4 Preterite

7.2.4.1 Meanings

7.2.4.2 Conjugation

7.2.4.3 Irregular Preterite

7.2.4.4 Differences between the Preterite and the Present Perfect

7.2.4.5 Differences between the Preterite and the Imperfect

7.2.5 Past Perfect and Pluperfect

7.2.5.1 Meanings

7.2.5.2 Conjugation

7.2.5.3 Irregular Pluperfect

7.2.6 Future

7.2.6.1 Meanings

7.2.6.2 Conjugation

7.2.4.3 Irregular Future

7.2.6 Future Perfect

7.2.6.1 Meanings

7.2.6.2 Conjugation

7.2.6.3 Irregular Future

7.2.7 Conditional

7.2.7.1 Meanings

7.2.7.2 Conjugation

7.2.8.3 Irregular Conditional

7.2.8 Conditional Perfect

7.2.8.1 Meanings

7.2.8.2 Conjugation

7.3 SubJunctive MOOD

7.3.1 Present Subjunctive

7.3.1.1 Meanings

7.3.1.2 Conjugation

7.3.1.3 Irregular Present Subjunctive

7.3.2 Present Perfect Subjunctive

7.3.2.1 Meanings

7.3.2.2 Conjugation

7.3.3 Past Subjunctive

7.3.3.1 Meanings

7.3.3.2 Conjugation 
7.3.4 Preterite

7.3.4.1 Meanings

7.3.4.2 Conjugation

7.3.5 Future Subjunctive

7.3.5.1 Meanings

7.3.5.2 Conjugation

7.3.6 Future PerfectSubjunctive

7.3.6.1 Meaning

7.3.6.2 Conjugation

7.4 IMPERATIVE MOOD

7.4.1 Conjugation

7.4.2 Irregular Imperative

7.5 Infinitive

7.4.1 Impersonal Infinitive

7.4.2 Personal Infinitive

7.6 Present Participle

7.7 COMPOUND INFINITIVE AND COMPOUND PRESENT PARTICIPLE

7.8 Past Participle

7.8.1 Irregular Past Participle

7.9 Passive voice

7.10 AuXiLIary Verbs

7.11 IMPERSONAL, UNIPERSONAL AND DEFECTIVE VERBS

7.11.1 Impersonal Verbs

7.11.2 Unipersonal Verbs

7.11.3 Defective Verbs

7.12 REFLEXIVE VERBS

7.13 Changing Vowel sounds in Verbal CONJUGation

Em Masip (2000, p. 104-21, 128-35), a morfologia verbal está inserida nas seções 2.7 (“'O grupo do verbo: verbo e advérbio") e 2.9 ("Exercícios de pessoa, número, tempo, modo, conjugação, voz e aspecto verbais") da segunda parte ("Morfossintaxe") sem dar informações sobre uso necessárias para a resolução de algumas das dezessete séries de exercícios de preenchimento de lacunas.

2.7.1 Definição de verbo

2.7.2 Classificação dos verbos

2.7.3 Flexão dos verbos

a) As pessoas verbais e seu número: primeira, segunda e terceira

b) Os tempos verbais e sua formação

c) Os modos

d) As conjugações

Verbo cantar $-1^{\mathrm{a}}$ conjugação completa

Beber - $2^{\mathrm{a}}$ conjugação

Partir $-3^{\mathrm{a}}$ conjugação

Ser - verbo auxiliar 
Estar - verbo auxiliar

Haver - verbo auxiliar

Ter - verbo auxiliar

$I r$ - verbo irregular

Pôr-verbo irregular

Lavar-se - conjugação pronominal

Irregularidades dos presentes de indicativo e subjuntivo

Irregularidades dos pretéritos

Irregularidades dos futuros

Irregularidades dos imperativos

Formas nominais: particípio e gerúndio: irregularidades

e) As vozes verbais: ativa, passiva e reflexiva

f) $\mathrm{O}$ aspecto verbal: relação com o significado e com o tempo

2.9 Exercícios de pessoa, número, tempo, modo, conjugação, voz e aspecto verbais

2.9.1 Exercícios de pessoa e número verbais (pronomes pessoais e de tratamento)

2.9.2 Exercícios de tempos, modos e conjugações verbais (indicativo)

2.9.3 Exercícios de tempos, modos e conjugações verbais (subjuntivo)

2.9.4 Exercícios de tempos, modos e conjugações verbais (imperativos afirmativos)

2.9.5 Exercícios de tempos, modos e conjugações verbais (imperativos negativos)

2.9.6 Exercícios de tempos, modos e conjugações verbais (formas não conjugadas)

2.9.7 Exercícios de verbos irregulares (presente do indicativo e subjuntivo)

2.9.8 Exercícios de verbos irregulares (presente do indicativo e subjuntivo)

2.9.9 Exercícios de verbos irregulares (presente do indicativo e subjuntivo)

2.9.10 Exercícios de verbos irregulares (presente do indicativo e subjuntivo)

2.9.11 Exercícios de verbos irregulares (pretéritos)

2.9.12 Exercícios de verbos irregulares (pretéritos)

2.9.13 Exercícios de verbos irregulares (futuros)

2.9.14 Exercícios de verbos irregulares (imperativos afirmativos)

2.9.15 Exercícios de verbos irregulares (imperativos negativos)

2.9.16 Exercícios de verbos reflexivos

2.9.17 Exercícios de verbos reflexivos

Perini (2002, p. 127-54, 579-96) trata da morfologia verbal nos capítulos 11 (“The Verb")

e 12 ("Irregular Verbs"), inseridos na seção III (“Inflexion") e em dois apêndices.

11.1 Mood, tense, person, number

11.2 Conjugations

11.3 The regular verb

12.1 Vowel shift in the radical

12.2 Irregular verbs

12.3 Anomalous verbs

12.4 Defective verbs

12.5 Double participles

Appendix 1: Regular Verbs

Appendix 2: Irregular and Anomalous 
Teyssier (1984, p. 144-88) apresenta o assunto no capítulo XII ("Morphologie du verbe"). No item I, apenas anuncia a existência dos duplos particípios que são tratados no capítulo seguinte ("Syntaxe du verbe").

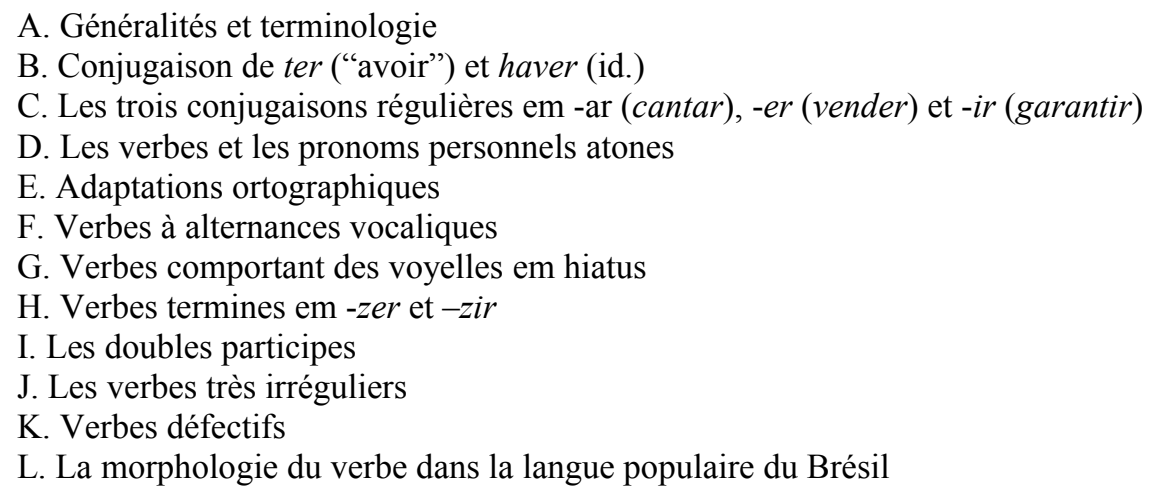

Vázquez Cuesta; Mendes da Luz (1980, p. 404-51) inserem o capítulo “O verbo” na seção de "Morfologia", apresentando uma bibliografia de obras de lingüística sobre o tema.

Generalidades

Visão geral da evolução do verbo do latim ao português

Alternância vocálica

Conjugação dos verbos auxiliares

Verbos regulares da voz activa

A voz passiva

A conjugação pronominal

A conjugação reflexa

A conjugação perifrástica

Verbos que sofrem mudanças ortográficas

Verbos defectivos

Outros tipos especiais de conjugação

Verbos irregulares

Particípios passados duplos

Bibliografia

\subsection{Gramáticas voltadas Para falantes de pORTUguês Como língua Materna}

Na parte intitulada "Gramática descritiva e normativa: as unidades do enunciado", Bechara (1999, p. 209-75) dedica a parte inicial da seção “6 Verbo" à morfologia nesta seqüência, que obedece, não ao índice, mas aos subtítulos que vêm no corpo do texto em negrito, abrindo parágrafo. $^{78}$

\footnotetext{
${ }^{78}$ Em Bechara (1975, p. 103-51), não figuram os itens A, B e C, dentre outras informações acrescentadas ou reformuladas pelo autor na edição revista e ampliada.
} 
Considerações gerais

A - A distinção de verbos nocionais e relacionais.

B - Categorias verbais segundo Roman Jakobson.

Explicação das categorias verbais

C - Tempo e aspecto segundo Eugenio Coseriu.

As pessoas do verbo

Os tempos do verbo

Os modos do verbo

As vozes do verbo

Voz passiva e passividade

Formas nominais do verbo

Verbos regulares, irregulares e anômalos

Verbos defectivos e abundantes

Locução verbal. Verbos auxiliares

Auxiliares causativos e sensitivos

Elementos estruturais do verbo

Tempos primitivos e derivados

A sílaba tônica nos verbos: formas rizotônicas e arrizotônicas

Alternância vocálica ou metafonia

Verbos notáveis quanto à pronúncia ou flexão

Verbos terminados em -zer, -zir: tipos fazer e traduzir

Variações gráficas na conjugação

Verbos em -ear e -iar

Erros freqüentes na conjugação de alguns verbos

Paradigma dos verbos regulares

Conjugação dos verbos auxiliares mais comuns

Conjugação de um verbo pronominal: apiedar-se

Conjugação de um verbo com pronome oblíquo átono

Conjugação dos verbos irregulares

Cunha; Cintra (1985, p. 367-436) tratam do tema na primeira metade do capítulo "Verbo".

\author{
Noções preliminares \\ Tempos simples \\ Verbos auxiliares e o seu emprego \\ Conjugação dos verbos regulares \\ Conjugação da voz passiva \\ Voz reflexiva \\ Conjugação de um verbo reflexivo \\ Conjugação dos verbos irregulares \\ Irregularidade verbal e discordância gráfica \\ Verbos com alternância vocálica \\ Outros tipos de irregularidade \\ Verbos de particípio irregular \\ Verbos abundantes \\ Verbos impessoais, unipessoais e defectivos
}

\title{
2.3 Manuais de Verbos
}

Lopes (1992, p. 9-xx) divide sua introdução em grandes partes:

$\mathrm{O}$ VERBo 


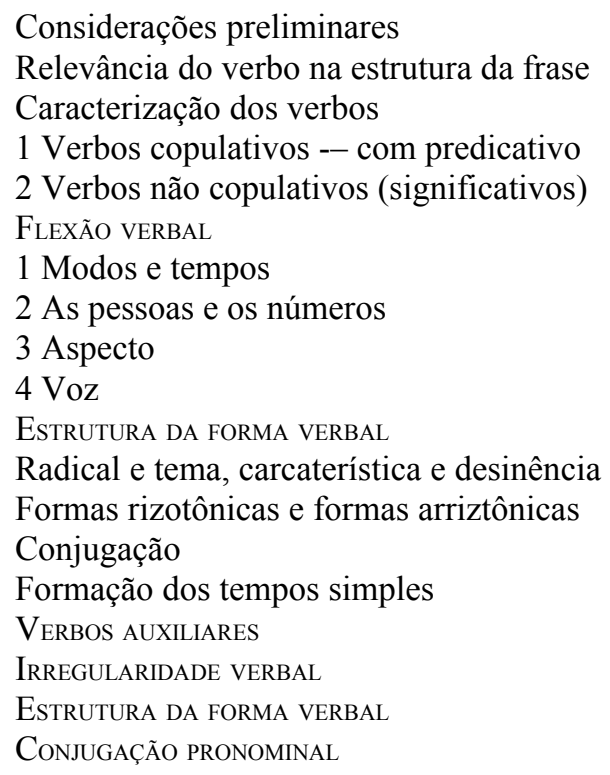

$\mathrm{Na}$ introdução, Rodrigues (2003, p. 5-20) apresenta "Um pouco de teoria para facilitar o uso":

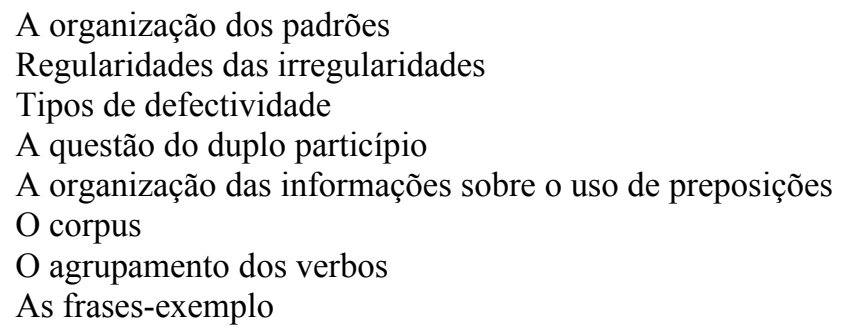

Lista, em seguida, sua "nominata" de mais de catorze mil verbos com remissão para as respectivas 149 tábuas de conjugação verbal (tempos simples de 97 padrões, alguns dos quais subdivididos em subpadrões; tempos compostos e conjugação passiva).

Às tábuas de conjugação Rodrigues (2003, p. 257-364) faz seguir uma seção intitulada "Uso das preposições", com dois glossários (um de 2038 verbos e outro de 469 "grupos de verbos"), em que reúne informações de caráter sintático-semântico, muitas vezes de forma redundante. Compare-se o que registra a autora no verbete do verbo abrir na subseção

- "Exemplário"

abrir

A varanda abria para os rochedos. ABRIR para

Abria-se com a avó. ABRIR-se com

A primavera abria-se em flores. DESATAR em

O doutorado abriu-lhe novas oportunidades. PERMITIR OD a OI

Abriu-se para novas experiências. Sem grupo

- "Grupos de verbos" 
ABRIR PARA

A varanda abria para os rochedos.

abrir $\bullet$ apontar $\bullet$ dar $\bullet$ deitar $\bullet$ olhar

Ryan (1991, p. 5-34) abre seu manual com um "Estudo gramatical do verbo", assim organizado:

\author{
Noções gerais \\ I. Definição \\ II. Conjugação \\ III.Radical e tema \\ IV. Formas rizotônicas e arrizotônicas \\ Flexões verbais \\ I. Número \\ II. Pessoa \\ III. Tempo \\ IV. Modo e formas nominais \\ V. Voz \\ Classificação dos verbos \\ I. Quanto à função \\ II. Quanto à flexão \\ Conjugação com os pronomes $o, a, o s, a s$ \\ I. Ênclise \\ II. Mesóclise
}

Em seguida, propõe 88 "modelos de conjugação verbal" nos tempos simples e compostos, agrupados em auxiliares, regulares (doze grupos), irregulares (sete grupos) e defectivos (três grupos): 


\begin{tabular}{|c|c|c|c|}
\hline & & \multicolumn{2}{|c|}{ Verbos auxiliares } \\
\hline 1 & & \multicolumn{2}{|l|}{ ser } \\
\hline 2 & & \multicolumn{2}{|l|}{ estar } \\
\hline 3 & & \multicolumn{2}{|l|}{ ter } \\
\hline 4 & & \multicolumn{2}{|c|}{ haver } \\
\hline & & \multirow{2}{*}{\multicolumn{2}{|c|}{ Verbos regulares }} \\
\hline & Grupo 1 & & \\
\hline 5 & & \multicolumn{2}{|c|}{$1^{\mathrm{a}}$ conjugação (-ar) cantar } \\
\hline 6 & & \multicolumn{2}{|c|}{$2^{\mathrm{a}}$ conjugação (-er) comer } \\
\hline 7 & & \multicolumn{2}{|c|}{$1^{\mathrm{a}}$ conjugação (-ir) partir } \\
\hline & Grupo 2 & \multicolumn{2}{|c|}{$\begin{array}{l}\text { Verbos cuja última sílaba do radical possui grupo vocálico que } \\
\text { forma ditongo: }\end{array}$} \\
\hline 8 & & & bailar \\
\hline 9 & & -au- & pausar \\
\hline 10 & & - ei- & peneirar \\
\hline 11 & & -eu- & endeusar \\
\hline 12 & & - oi- & amoitar \\
\hline 13 & & - ou- & roubar \\
\hline 14 & & -ui- & cuidar \\
\hline
\end{tabular}

Verbos irregulares

\section{Grupo 1 em -air}

Verbos defectivos

Verbos aos quais faltam s primeira pessoa do singular do presente do indicatico e suas derivadas

Grupo 1 abolir

\begin{tabular}{|c|}
\hline 77 \\
\hline 78 \\
\hline 79 \\
\hline 80 \\
\hline
\end{tabular}




\section{APÊNDICE 2}

\section{VERBETES DESCRITIVOS DA MORFOLOGIA VERBAL}

Neste Apêndice, transcrevi o texto de 604 verbetes de Houaiss; Villar (2001a; 2001b) assim distribuídos:

- $\quad 2.1$ TeRminaÇÕes

- $\quad$ 2.2 Sufixos Verbais

- $\quad 2.3$ Verbos MONOSSILÁBICOS

- $\quad 2.4$ TeRminaÇõES NÃO-ESTABELECIDAS

Nos verbetes de terminação, sufixo e verbo monossilábico, foram suprimidas as informações estranhas à morfologia verbal. Logo depois da entrada, entre parênteses, foi inserido o número de verbos correspondentes à terminação ou ao sufixo e, no caso dos verbos monossilábicos, o número de verbos deles derivados, obtido por meio da "pesquisa combinada", acessível no link "Pesquisas" de Houaiss; Villar (2001a).

Comparem-se as citações que correspondem (a) ao texto integral do dicionário e (b) ao texto parcial transcrito no apêndice, nos seguintes exemplos:

- terminação -abar

(a) term. todos os v. da língua assim terminados são regulares $\odot$ USO ver, no verbete terminação, o que se diz em uso

(b) term. (24) todos os v. da língua assim terminados são regulares

- $\quad$ sufixo -ar

(a) suf. num universo de 100 mil palavras, levantam-se cerca de 12 mil com esta term.: 1) cerca de 300 adj., do lat. -aris, $e$, alternativo do suf. -al do lat. -ális, e; é de notar, para estes casos, que a opção linguageira por -ar adj., quase que sistematicamente, ocorre em palavras cujo rad. encerra $l$, numa tendência clara à dissimulação de dois $l l$; a série de adjetivos, sempre de dois gên., compreende um bom número de pal. que se substantivam, ocasional ou quase regularmente; nesses casos, o gên. da pal. substv. é quase sistematicamente função de silepse, subentendido, assim, o gên. do subst. pensado: os (elementos) preliminares, as (noções) preliminares, a (decisão, sentença) liminar, o (despacho) liminar etc.: acicular, alvar, alveolar, apendicular, apicular, armilar, auricular, axilar, balear, balnear, biliar, bracteolar, bursicular, calendar, 
canicular, capilar, carpelar, caruncular, cavalar, celular, cerebelar, clavicular, coclear, codicilar, consular, conventicular, corpuscular, craniolar, crepuscular, cubicular, cuticular, denticular, dilucular, dipolar, discipular, elementar, epistolar, espetacular, exemplar, fac-similar, falimentar, familiar, fascicular, fibrilar, filamentar, folicular, funicular, furuncular, ganglionar, glaciar, glandular, globular, gongilar, gular, heteropolar, homopolar, incunabular, infibular, intercalar, lamelar, lanar, lanceolar, larvar, liminar, linear, lobular, locular, luminar, lunissolar, lunular, magiar (caso em que não há $l$ radical), malabar, malear, maleolar, mamilar, mandibular, medular, milenar, miliar, molar, molecular, muscular, navicular, nuclear, octangular, ocular, opercular, opuscular, oracular, orbicular, ostiolar, panicular, papilar, parcelar, particular, patelar, peciolar, peciolular, peduncular, peninsular, perpendicular, piacular, pilular, plumular, polar, popular, preambular, preliminar, prostibular, puelar, pulmonar, quacular, quadrilocular, radicular, retangular, reticular, rudimentar (caso em que não há $l$ radical), sacular, salutar, secular, semicircular, sexangular, sexcelular, sextissecular, singular, solear, subliminar, sublinear, sumicular, superciliar, tegular, tentacular, testicular, tissular, titular, torcular, trabecular, triangular, tubercular, tubular, tumular, utricular, uvular, vacuolar, valecular, valvar, valvular, variolar, ventricular, verlenticular, vesicular, vestibular, vexilar, vice-consular, vocabular, vulgar, vulvar etc.; 2) quase todas correspondentes a verbos da nossa $1^{\mathrm{a}}$ conj. - em que há o $a$ temático dessa conj. e o $r$ desinencial do inf. -, que perdura praticamente como a única fecunda; é de notar que todos os v. são substantiváveis, alguns tão regularmente que são pensados como subst. (poder, haver, andar, vagar etc.), outros são pensáveis como subst., em grau decrescente em função do inusitado: o alegar, o esmiuçar, o contemporizar etc.; constitui, assim, uma anomalia a pal. cultivar quando tomada como subst. fem., em técnicas botânicas, como braq. do ing. culti(vated) var(iation), ver-lhe o caso no verbete próprio; 3) e cerca de seis dezenas de subst. (poucos dos quais com valor coletivo), em que a term. não é de form. sistemática; eis a série, em que se notará serem sempre masc., quaisquer que sejam suas orig.: alamar, alfeizar, algar, aliazar, alizar, aljazar, alveitar, ar, avatar, avelar, azar, baltar, bar, bazar, bem-estar, bilhar, bulevar, calamar, calazar, calcanhar, caviar, cocar, coltar, desar, dinar, esgar, espaldar, folar, glaciar, hangar, jacamar, lagar, lar, limiar, linguajar, lupanar, malestar, mar (mas ver o verbete -mar), mesotenar, microbar, milhar, milibar, minibar, olivar, par, patamar, pega-p(a)ra-capar, placar, pomar, pulsar, quasar, radar, samovar, tear, tzar/czar etc.

(b) (13209) suf. num universo de 100 mil palavras, levantam-se cerca de 12 mil com esta term. [...] quase todas correspondentes a verbos da nossa $1^{\mathrm{a}}$ conj. - em que há o $a$ temático dessa conj. e o $r$ desinencial do inf. -, que perdura praticamente como a única fecunda $[\ldots]$

\section{- verbo monossilábico crer}

(a) v. (sXIII cf. IVPM) 1 t.d., t.i. tomar por verdadeiro, ter por certo, ter confiança em (alguém ou algo); acreditar $<$ creram que tudo valera a pena $><$ c. na revolução $><$ c. em Deus $>\square$ ver gram/uso a seguir $\mathbf{2}$ t.d., t.i. confiar em, aceitar como verdadeiras (palavras ou manifestações) de <era certo que o criam e respeitavam $><$ os apóstolos criam a Cristo $><$ tiveram de c. naquela declaração $>\square$ ver gram/uso a seguir 3 t.d.pred. e pron. formar idéia sem base real; imaginar, pensar, presumir $<$ ela ainda o cria sincero $><$ ele se crê feliz $>3.1$ t.d. tomar como provável; pensar <ante o conflito, cremos que fugirá $>4$ t.d. afirmar por um ato de julgamento voluntário; julgar <seria o homem totalmente responsável por sua própria salvação, como o criam os pelagianistas?> 5 int. REL ter fé, crença, falando esp. de crença religiosa, mística; acreditar $<$ devotou-se porque crê $>$ $<e ́$ necessário c. sem vacilar $>\mathbf{6}$ pron. ant. fiar-se, confiar em <era um homem que se cria de seus inimigos $>\odot$ GRAM conj.irreg.: a) pres.ind.: creio, crês, crê, cremos, credes, crêem; b) imper.: crê, creia, creiamos, crede, creiam; c) pres.subj.: creia etc.; part.: crido $\odot$ GRAM/USO presentemente, nas acp. 1 e 2 o verbo quase só é empr. 
como transitivo indireto $\square$ ETIM lat. credo, is, credidi, creditum, credère 'crer, confiar, entregar, recomendar, dar crédito, ter por verdadeiro, ter como certo, julgar', pelo lat.vulg. *credēre > port. arc. creer; ver cred-; f.hist. sXIII creer, sXIII creo, sXIV creyo, sXV crer, sXV creio $\square$ SIN/VAR ver sinonímia de achar e acreditar $\odot$ ANT desacreditar, descrer, duvidar; ver tb. antonímia de acreditar $\odot$ HOM creste /ê/ (2 $2^{\mathrm{a}} \mathrm{p} . \mathrm{s}$.), crestes /ê/ ( $\left.2^{\mathrm{a}} \mathrm{p} . \mathrm{pl}.\right) /$ creste, crestes (fl.crestar) $\odot$ PAR crê ( $\left.3^{\mathrm{a}} \mathrm{p} . \mathrm{s}.\right) /$ cré (s.m.); cresse /ê/ ( $1^{\mathrm{a}} 3^{\mathrm{a}}$ p.s.); cresses /ê/ ( $2^{\mathrm{a}}$ p.s.)/ cresce, cresces (fl.crescer); críamos (1 $\left.{ }^{\mathrm{a}} \mathrm{p} . \mathrm{pl}.\right)$, críeis (2a.pl.)/ criamos, crieis (fl.criar)

(b) crer (v. [...] conj.irreg.: a) pres.ind.: creio, crês, crê, cremos, credes, crêem; b) imper.: crê, creia, creiamos, crede, creiam; c) pres.subj.: creia etc.; part.: crido [...] lat. credo, is, credĭdi, credütum, creděre 'crer, confiar, entregar, recomendar, dar crédito, ter por verdadeiro, ter como certo, julgar', pelo lat.vulg. *credēre > port. arc. creer; ver cred-; f.hist. sXIII creer, sXIII creo, sXIV creyo, sXV crer, sXV creio [...]

Na transcrição de todos os verbetes, corrigiram-se lapsos inequívocos de revisão, como a presença de vírgula no final do verbete -orcar: “[...] forqueis,”. Nos casos que davam margem a mais de uma interpretação o texto foi mantido tal como estava e, em nota:

- comentaram-se lapsos de revisão (relativos a aspectos formais) e/ou edição (relativos a aspectos conceituais), como em -andir, rotulado como el. comp., e não como term.;

- mencionarampse os verbos quando de baixa ocorrência (um ou dois), como em -alfar, que corresponde apenas a escalfar e esfalfar;

- reproduziu-se a definição (ou apenas a primeira quando havia mais de uma) constante no verbete de verbos menos comuns, como escalfar ("aquecer, esquentar (água) no escalfador");

- reproduziu-se informações da tábua de conjugação quando as do verbete de terminação são insuficientes, como em -anir, em que os redatores não mencionam enganir, na tábua nãoconjugado na $1^{\text {a }}$ p.s.pres.ind. e, decorrentemente, no pres.subj., e

- justificou-se a discrepância entre o número de verbos indicado entre parênteses e o mencionado no verbete.

Finalmente, estão listadas as terminações não-estabelecidas, agrupando-as segundo os critérios supostamente usados pelos editores.

\subsection{Terminações}

1 -abar (24) term. todos os v. da língua assim terminados são regulares

2 -aber (7) term. o v. caber (e derivados) tem caibo na $1^{\mathrm{a}} \mathrm{p} . \mathrm{s}$. [do pres.] ind. e o pres.subj. conexo (caiba, caibas, caibamos etc.), e o rad. do perf. em coube (coubeste, coube, coubemos, coubestes, couberam), com os conexos coubera etc., couber etc., coubesse etc.; o v. saber (e derivados) tem sei na $1^{\text {a }}$ p.s.ind., mas o pres.subj. saiba etc.; e o rad. do perf. soube 
(soubeste, soube, soubemos, soubestes, souberam), com os conexos soubera etc., souber etc., soubesse etc.

3 -abir (1) term. o v. desenxabir, de uso teórico, pela freqüência do seu part. desenxabido como adj., postula a possibilidade de conjugação nas f. arrizotônicas $^{79}$

4 -abrir (6) term. o verbo abrir e seus derivados são regulares, salvo no part. aberto; desabrido (ver) é, quase certamente, de outro étimo que desabrir, cujo part. é desaberto

5 -acar (56) term. todos os v. da língua assim terminados são regulares, mas mudam o -c- em $-q u$ - antes de $-e$ desinencial

6 -açar (113) term. de cunho popular em voc. documentados antes do sXIV na língua: pelo exemplário (abraçar, adelgaçar, ameaçar, amelaçar, amordaçar, arruaçar, avoaçar, caçar, chumaçar, couraçar, desembaraçar, embaraçar, enfumaçar, engraçar, enlaçar, fumaçar, mordaçar, sobraçar - são cerca de 90 voc. em um universo de cem mil), vê-se que há casos em que se trata de term. provinda de primitivos terminados em -aço ou -aça, + a term. da $1^{a}$ conj. (braço, ameaça, caça etc.), e casos, com valor sufixal, em voc. compostos de -aço ou -aça + ar como elo intermédio, com caráter de 'repetição, reiteração, reforço' (mordaçar, de morder através de mordaça; enfumaçar, de fumaça de fumo; amelaçar, de melaço de mel); todos os v. da língua assim terminados são regulares, mas mudam o -ç- em -c- antes de -e- ${ }^{80}$

7 -achar (35) term. todos os v. da língua assim terminados são regulares

8 -acir (0) todos os v. da língua assim terminados são regulares ${ }^{81}$

9 -acrar (8) term. todos os v. da língua assim terminados são regulares

10 -actar (8) term. os poucos v. da língua assim terminados são regulares (compacto, compactas etc.; compacte, compactes etc.)

11 -adar (58) term. todos os v. da língua assim terminados são regulares

12 -adir (9) term. os v. da língua com essa term. são regulares (despersuadir, dissuadir, evadir, invadir, persuadir, suadir); adir, entretanto, nas duas acp. principais, só se conjuga nas $\mathrm{f}$. arrizotônicas $^{82}$

13 -adrar (13) term. todos os v. da língua assim terminados são regulares

14 -aer (1) term. de um só v., fóssil, raer, reduzido, na acp. de 'raspar ou vassourar o forno aquecido', ao uso no infinitivo; ver -oer ${ }^{83}$

\footnotetext{
${ }^{79}$ A observação de que desenxabir é de "uso teórico" perde o sentido quando se verifica que o verbo ("retirar o sabor a") está efetivamente conjugado na tábua.

${ }^{80}$ Note-se que os lexicógrafos registram 113 (e não “cerca de 90 voc.") verbos em -açar. "Cem mil” deve ser a quantidade aproximada de palavras de todas as categorias gramaticais registradas no dicionário, considerando-se que o total de verbos é de 13762.

${ }^{81} \mathrm{O}$ número entre parênteses é zero porque não há registro de nenhum verbo em -acir.

${ }^{82} \mathbf{1}^{\circ}$ ) Além dos verbos mencionados, há registro de anadir ("acrescentar, juntar (algo)") e anhadir (com remissão para anadir), que na tábua se conjugam apenas nas formas arrizotônicas. $\mathbf{2}^{\circ}$ ) A observação de que "adir, entretanto, nas duas acp. principais, só se conjuga nas f. arrizotônicas" perde o sentido quando se verifica que, nas três acepções ("acrescentar ou juntar (algo) a uma outra coisa", "pôr-se junto, pôr-se ao lado; agregar-se, incorporar-se", registradas em ${ }^{1}$ adir, e "entrar na posse de (herança)", registrada em ${ }^{2}$ adir), o verbo só se conjuga nas formas arrizotônicas.

${ }^{83}$ A remissão para -oer talvez esteja aí pelo fato de poer, assim como raer, ser declarado verbo "fóssill. De todo modo, em -oer não há remissão cruzada para -aer.
} 
15 -afar (76) term. todos os v. da língua assim terminados são regulares

16 -agar (48) term. todos os v. da língua assim terminados são regulares, mas o - $g$ - passa a -guantes de $-e$ desinencial

17 -agir (9) term. os poucos v. da língua com essa term. são regulares, com o - $g$ - passando a $-j$ antes de -o e - $a$ desinenciais (reajo, donde reaja etc.); vagir, porém, é tido como defectivo, sem as f. que seriam com $-j-$

18 -agnar (2) term. os poucos v. da língua assim terminados são regulares: estagno, estagnas etc., estagne, estagnes etc. ${ }^{84}$

19 -agrar (19) term. todos os v. da língua assim terminados são regulares (açumagrar, agrar, almagrar, avinagrar, conflagrar, consagrar, deflagrar, flagrar, sagrar e conexos e derivados $)^{85}$

20 -aguar (5) term. os v. como os v. como aguar, desaguar, enxaguar, e conexos, como apaniguar, apaziguar, averiguar, minguar, contrastam graficamente com magoar (e, mais genericamente, com os v. em -oar, como abençoar, caçoar, coar, ecoar etc.); tal como no caso de adequar, antiquar, apropinquar, deliquar, obliquar (ver -iquar, -inquar), há neles controvérsia preceptiva quanto à acentuação nas f. rizotônicas, mas a distinção gráfica -guar de -goar visa às possibilidades da silabação (a-guar, de-sa-guar, mas ma-go-ar, re-ma-go-ar, des-ma-go-ar), donde, correlatamente, a acentuação nas f. rizotônicas (águo, águas, água, águam, ágüe, ágües, ágüe, ágüem, mas magôo, magoas, magoa, magoam, magoe, magoes, magoe, magoem)

21 -aiar (0) term. todos os v. da língua assim terminados são regulares ${ }^{86}$

22 -aibrar (5) term. os poucos v. da língua assim terminados são regulares

23 -aidar (0) term. o único v. da língua com esta term. é envaidar, antigo e de raro uso; as suas f. rizotônicas deviam ter sido envaído, envaídas etc., envaíde, envaídes etc., mas hoje em dia é registrado como se regular, envaido, envaidas etc., envaide, envaides etc. ${ }^{87}$

24 -aigar (0) term. os poucos v. da língua com essa term. são regulares, mas trocam o $g$ por $g u$ antes de $e^{88}$

25 -ailar (0) term. o só v. da língua com essa term. (bailar) é regular (bailo, bailas etc., baile, bailes etc. $)^{89}$

\footnotetext{
${ }^{84}$ Os dois verbos são estagnar e desestagnar.

${ }^{85} \mathbf{1}^{\mathbf{0}}$ ) É estranho que a lista de verbos venha seguida de "e conexos e derivados", pois dentre eles já há derivados de flagrar (conflagrar e deflagrar) e sagrar (consagrar); ademais, os restantes não têm derivados. Fica-se ainda sem saber o que seriam os "conexos". $\mathbf{2}^{\circ}$ ) Além dos verbos mencionados, há registro de três derivados de sagrar (desconsagrar, dessagrar e reconsagrar) e outros verbos que não são derivados de nenhum outro: abisagrar ("dar aparência de bisagra a", havendo em bisagra remissão para dobradiça), assumagrar (com remissão para sumagrar, "curtir ou tingir com sumagre ('pó')"), emagrar, ensumagrar ("curtir, preparar com sumagre ("pó')"), envinagrar, sumagrar e vinagrar.

${ }^{86} \mathrm{O}$ número entre parênteses é zero porque raiar e outros 35 verbos em -aiar estão contabilizados em -iar.

${ }^{87} \mathrm{O}$ número entre parênteses é zero porque envaidar está contabilizado em -idar.

${ }^{88} \mathrm{O}$ número entre parênteses é zero porque arraigar e outros três verbos em -aigar estão contabilizados em -igar.

${ }^{89} \mathrm{O}$ número entre parênteses é zero porque bailar está contabilizado em -ilar.
} 
26 -aimar (0) term. todos os v. da língua com essa term. são regulares, isto é, as suas $\mathrm{f}$. rizotônicas ou arrizotônicas têm o ditongo $a i$ (descendente) preservado; mas sua pronúncia é variável, de oral aberto a nasal, consoante as regiões ${ }^{90}$

27 -ainar (0) term. os poucos v. da língua com essa term. são regulares, isto é, preservam o ditongo ai tanto nas f. rizotônicas como nas arrizotônicas, mas seu timbre flutua de oral aberto a nasal, conforme as regiões ${ }^{91}$

28 -aipar (0) term. todos os v. da língua com essa term. são regulares, isto é, preservam o ditongo ai tanto nas f. rizotônicas como nas arrizotônicas ${ }^{92}$

29 -air (24) term. de verbos da $3^{\text {a }}$ conj., como abstrair, atrair, cair, contrair, decair, descair, detrair, distrair, embair, esvair, extrair, protrair, recair, ressair, retrair, retrotrair, sair, sobressair, subtrair, trair (reduzidos, como se vê, a cair e compostos, trair e compostos, sair e compostos, ademais dos dois avulsos, embair e esvair); são co-regulares, conjugáveis segundo o padrão, p.ex., de sair: saio, sais, sai, saímos, saís, saem; saía etc.; saí, saíste, saiu, saímos, saístes, saíram; sairei etc.; sairia etc.; saia, saias, saiamos, saiais, saiam; saísse etc.; sair, saíres, sair, sairmos, sairdes, saírem; saindo; saído; ver -uir ${ }^{93}$

30 -airar (0) term. todos os v. da língua com essa term. são regulares, isto é, preservam o ditongo $a i$ tanto nas f. rizotônicas quanto nas arrizotônicas ${ }^{94}$

31 -airrar (0) term. o só v. da língua com essa term. (abairrar) é regular, preservando o ditongo ai tanto nas f. rizotônicas como nas arrizotônicas (abairro, abairres etc. $)^{95}$

32 -aitar (0) term. os poucos v. da língua com essa term. são regulares (entupigaito, entupigaitamos etc. $)^{96}$

33 -aivar (0) term. todos os v. da língua com essa term. são regulares, preservando o ditongo ai em todas as f. (saraivo, saraivas etc. $)^{97}$

\footnotetext{
${ }^{90} \mathrm{O}$ número entre parênteses é zero porque esfaimar e outros seis verbos em -aimar estão contabilizados em -imar.

${ }^{91} \mathrm{O}$ número entre parênteses é zero porque amainar e outros oito verbos em -ainar estão contabilizados em -inar.

${ }^{92} \mathrm{O}$ número entre parênteses é zero porque naipar ("jogar cartas do mesmo naipe") e outros quatro verbos em -aipar estão contabilizados em -ipar.

${ }^{93} \mathbf{1}^{\mathbf{0}}$ ) Além de embair ("induzir deliberadamente em erro; lograr, iludir, seduzir"), que não segue o padrão de sair apesar de em seu verbete haver a remissão "a respeito da conj. deste verbo, ver -air", e esvair, há registro de desvair, com remissão para esvair. $\mathbf{2}^{\circ}$ ) Na tábua, embair conjuga-se apenas nas formas arrizotônicas e, no seu próprio verbete, observa-e que é "v. defect; us. unicamente nas formas em que o $i$ se segue ao radical", mas também - contraditoriamente - que "a respeito da conj. deste verbo, ver -air". $3^{\circ}$ ) A remissão para -uir talvez esteja aí pelo fato de haver formas paralelas dos verbos nas duas terminações no presente do indicativo (sai e atribui, p.ex.) e no pretérito perfeito do indicativo (sai e atribuí, p.ex.) De todo modo, em -uir há remissão para -ear, e não para -air.

${ }^{94} \mathrm{O}$ número entre parênteses é zero porque pairar e outros seis verbos em -airar estão contabilizados em -irar.

${ }^{95} \mathrm{O}$ número entre parênteses é zero porque abairrar está contabilizado em -irrar.

${ }^{96} \mathrm{O}$ número entre parênteses é zero porque entupigaitar ("causar embaraço ou embaraçar-se; fazer calar ou calar(-se); atrapalhar(-se), confundir(-se), desorientar(-se), desnortear(-se)" e outros cinco verbos em -aitar estão contabilizados em -itar.

${ }^{97} \mathrm{O}$ número entre parênteses é zero porque saraivar e outros oito verbos em -aivar estão contabilizados em -ivar.
} 
34 -aixar (0) term. todos os v. da língua com essa term. são regulares, preservando o ditongo ai em todas as f. (abaixo, abaixamos etc., abaixe etc.) ${ }^{98}$

35 -ajar (25) term. todos os v. da língua com essa term. são regulares

36 -alar (94) term. todos os v. da língua com essa term. são regulares

37 -alcar (7) term. todos os v. da língua com essa term. são regulares, mas o $c$ muda em qu antes de $e$ (decalque, decalques, decalquemos etc.)

38 -alçar (12) term. todos os v. da língua com essa term. são regulares, mas o ç muda em $c$ antes de $e$ (calce, calcemos, realce, realcemos etc.)

39 -aldar (20) term. todos os v. da língua com essa term. são regulares

40 -aldir (3) term. o só v. da língua com essa term., gualdir, documenta-se raramente, de preferência em f. arrizotônicas (gualdimos, gualdis; gualdia etc.; gualdi etc.; gualdira etc.) ${ }^{99}$

41 -aler (3) term. o v. valer (e seus der.) tem a $1^{\text {a }}$ p.s. do pres.ind. valho e o pres.subj. conexo valha etc.

42 -alfar (2) term. todos os v. da língua com essa term. são regulares ${ }^{100}$

43 -algar (15) term. todos os v. da língua com essa term. são regulares, mas o - $g$ - passa a -guantes de $-e$ desinencial

44 -alhar (148) term. todos os v. da língua com essa term. são regulares; ver -lhar quanto à sua morfologia

45 -alir (4) term. os poucos v. da língua com essa term. (balir, combalir, encalir e falir) têm de regra todos as f. arrizotônicas; não têm a $1^{\mathrm{a}} \mathrm{p}$.s.pres.ind. e logo não têm o pres.subj.; há ocorrências de bale, balem, combale, combalem ${ }^{101}$

46 -almar (14) term. todos os v. da língua com essa term. são regulares

47 -alpar (3) term. os poucos v. da língua com essa term. são regulares

48 -alrar (3) term. os poucos v. da língua com essa term. são regulares

49 -alsar (10) term. os v. da língua com essa term. são regulares

50 -altar (18) term. todos os v. da língua com essa term. são regulares

51 -alvar (7) term. os v. da língua com essa term. são regulares

52 -amar (69) term. todos os v. da língua com essa term. são regulares, mas o $a$ antenasal é vogal variável, de oral a nasalado, segundo as regiões

53 -ambar (17) term. todos os v. da língua com essa term. são regulares

54 -amber (3) term. o v. lamber (e seus der.) é regular

\footnotetext{
${ }^{98} \mathrm{O}$ número entre parênteses é zero porque baixar e outros dez verbos em -aixar estão contabilizados em -izar.

99 Além de gualdir ("comer apressadamente; engolir"), há registro também de galdir (com remissão para gualdir), que na tábua se conjuga apenas nas formas arrizotônicas, e esbaldir ("malgastar, dissipar"), que na tábua se conjuga regularmente em todas as formas.

${ }^{100}$ Os dois verbos são escalfar ("aquecer, esquentar (água) no escalfador") e esfalfar.

${ }^{101}$ Combalir é definido como "tornar(-se) débil, fraco; abalar(-se), enfraquecer(-se)" e encalir, como "assar ou cozinhar brevemente (carne) a fim de mantê-la conservada".
} 
55 -amblar (3) term. os poucos v. da língua com essa term. são regulares

56 -ambrar (6) term. os poucos v. da língua com essa term. são regulares

57 -amir (2) term. os v. bramir e rebramir são tidos como defectivos, a saber, sem a $1^{\text {a }}$ p.s.pres.ind. e, decorrentemente, sem o pres.subj.

58 -ampar (28) term. todos os v. da língua com essa term. são regulares

59 -anar (105) term. todos os v. da língua com essa term. são regulares, mas o $a$ antenasal é vogal variável, de oral a nasalado, segundo as regiões

60 -ancar (41) term. todos os v. da língua com essa term. são regulares, mas o $c$ muda em qu antes de $e$ (abanques)

61 -ançar (34) term. todos os v. da língua com essa term. são regulares, mas o $c$ muda em $c$ antes de $e$ (dances etc.)

62 -anchar (23) term. todos os v. da língua com essa term. são regulares

63 -andar (27) term. todos os v. da língua com essa term. são regulares

64 -andir (4) el. comp. dos poucos v. dessa term., escandir e expandir são regulares, mas brandir é tido como defectivo na $1^{\text {a }}$ p.s.pres.ind. e, decorrentemente, no pres.subj. ${ }^{102}$

65 -andrar (5) term. os poucos v. da língua com essa term. são regulares

66 -angar (33) term. os v. da língua com essa term. são regulares, mas o $g$ muda em gu antes de $e$ (fandangues)

67 -anger (11) term. os v. da língua com essa term. têm a $1^{a}$ p.s. do pres.ind. -anjo (com o pres.subj. conexo: tanja, tanjas etc.), sendo as demais f. regulares

68 -angir (3) term. os poucos v. dessa term. são regulares, com o $g$ passando a $j$ antes de $o$ e $a$ desinenciais (tipo ranjo, ranja etc.) ${ }^{103}$

69 -angrar (3) term. os poucos v. da língua com essa term. são regulares

70 -anguir (2) term. ocorre nos v. entanguir e languir, para os quais as preceptivas gramaticais aconselham ou apenas a conj. das f. arrizotônicas ou apenas a omissão da $1^{a}$ p.s. do pres.ind. e, decorrentemente, todo o pres.subj.; em quaisquer casos, o $-u$ - não é pronunciado ${ }^{104}$

71 -anhar (62) term. de verbos da $1^{\mathrm{a}}$ conj., conexos com nomes em -anha ou -anho, de que guardam as conotações 1) de 'aumentativo' (abocanhar [...]) 2) de 'mera conexão ativa' (acalcanhar [...]); todos os v. da língua com essa term. são regulares, mas a vogal antenasal é variável, indo de oral a nasalada, segundo as regiões

72 -anir (6) term. dos v. com essa term., granir é regular, ganir metaforicamente tb. o é, enquanto banir, exinanir e inanir não têm a $1^{\mathrm{a}}$ p.s.pres.ind. e, decorrentemente, o pres.subj. ${ }^{105}$

\footnotetext{
$102 \mathbf{1}^{\mathbf{0}}$ ) Certamente o “el. comp."aí está no lugar de term. $\mathbf{2}^{\mathbf{0}}$ ) Além de brandir, há registro também de bandir ("banir quem não pertence ao mesmo partido ou facção; desterrar, exilar"), que na tábua não se conjuga na $1^{\text {a }}$ p.s. pres.ind. e em todo o pres.subj.

${ }^{103}$ Em rangir, há remissão para ranger.

${ }^{104}$ Entanguir é definido como "tornar(-se) hirto de frio; enregelar(-se), entanguecer(-se)") e, em languir, há remissão para languescer ("perder a vitalidade; definhar(-se)").

${ }^{105}$ Além dos verbos mencionados, há registro também de enganir ("estar ou ficar encolhido (ger. por causa do frio); entanguecer, entanguir"), que, na tábua, não se conjuga na $1^{\text {a }}$ p.s. pres.ind. e em todo o pres.subj.
} 
73 -anjar (12) term. os poucos v. da língua com essa term. são regulares

74 -anquir (1) term. o v. branquir é defectivo na $1^{\mathrm{a}} \mathrm{p} . \mathrm{s} . p r e s . i n d$. e, decorrentemente, no pres.subj.; por isso, não se impõe a mudança ortográfica do $q u \mathrm{em} c$ (que ocorreria antes de $o$ e $a$ desinenciais)

75 -ansar (6) term. os poucos v. da língua com essa term. são regulares

76 -ansir (3) term. o v. transir $(s=z)$ e seus der. (retransir e pertransir) só se conjugam nas f. arrizotônicas $^{106}$

77 -antar (57) term. todos os v. da língua com essa term. são regulares

78 -anter (0) term. o v. manter conjuga-se como ter, ver $^{107}$

79 -antir (1) term. o v. garantir (e seus der. potenciais tipo regarantir, desgarantir, pergarantir etc.) é regular

80 -anzar (11) term. todos os v. da língua com essa term. são regulares

81 -anzir (3) term. o v. franzir (e seus der. desfranzir, refranzir) é regular

82 -apar (36) term. todos os v. da língua com essa term. são regulares

83 -apir (1) term. o v. usucapir é regular, embora raro na $1^{\mathrm{a}}$ p.s.pres.ind. e no pres.subj. ${ }^{108}$

84 -aptar (8) term. todos os v. da língua com essa term. são regulares (raptas, rapte, raptem, rapto etc.

85 -arar (77) term. 1) todos os v. da língua com essa term. são regulares, sendo fonologicamente irrelevante a diferença fonética entre $\mathrm{o}-a$ - das f. rizotônicas (anteorais ou antenasais) e o $-a$ das f. arrizotônicas (anteorais ou antenasais); 2) do ponto de vista morfológico, são grupáveis a) os v. da base lat. v. paro, as, āvi, ātum, àre 'aprestar, aparelhar, preparar, ordenar, dispor, adquirir, obter, ordenar etc.' [...] b) verbos em que a base rad. termina em -ar [...] c) são latinismos puros arar e exarar; d) o brasileirismo quarar é tido como var. de corar (cor+ar); e) por fim, há abichar e abicharar, enfumar e enfumarar, esfumar e esfumarar, filhar e filharar, fumar e fumarar, lambar e lambarar, em notável coerência, em que o segundo el. encerra a função a um tempo mórfica e semântica - como suf. intensificador e desambiguador ${ }^{109}$

\footnotetext{
${ }^{106}$ Transir é definido como "passar através de; transpassar"; retransir, como "passar (algo) de lado a lado, ou de uma ponta a outra; penetrar, trespassar" e pertransir, como "transir de maneira completa; atravessar de lado a lado".

${ }^{107} \mathrm{O}$ número entre parênteses é zero porque manter está contabilizado em ter.

${ }^{108}$ Usucapir é definido como "adquirir-se por uso".

${ }^{109} \mathbf{1}^{\mathbf{0}}$ ) Como a observação de que é "fonologicamente irrelevante a diferença fonética entre o - $a$ - das f. rizotônicas (anteorais ou antenasais) e o $-a$ - das f. arrizotônicas (anteorais ou antenasais)" é cabível apenas para um conjunto de terminações iniciadas em -a, que pode ser seguido de consoante oral (como -arar, mas também em -alar, -atar, etc.) ou nasal (como -amar, -anar, etc.), fica desconsiderada para efeito da análise feita neste trabalho. $\mathbf{2}^{\circ}$ ) Na verdade, os redatores não agrupam os verbos do ponto de vista morfológico, mas de uma mescla de referências etimológicas ("de base lat.", "latinismos puros", "brasileirismo"), mórficas ("em que a base rad. termina em -ar", "suf.") e semânticas ("intensificador e desambiguador"). 30) É estranho que os redatores falem em "função mórfica e semântica", pois na terminologia gramatical função é termo relacionado à sintaxe: seria preferível que tivessem falado em estrutura mórfica e carga semântica. $4^{\circ}$ ) Difícil entender o sentido dos adjetivos intensificador e, sobretudo, desambiguador. Em nenhum dos pares de verbos, o "segundo elemento" (supostamente -arar) funciona como sufixo intensificador. Comparem-se, p.ex., as definições de abicharar (com remissão para abichalhar, "dar ou tomar características de efeminado
} 
86 -arbar (6) term. os poucos v. da língua com essa term. são regulares

87 -arcar (19) term. os v. da língua com essa term. são regulares, mas o - c- muda em -qu- antes de $-e$ desinencial (embarque etc.)

88 -arçar (3) term. os poucos v. da língua com essa term. são regulares, mas o -ç- muda em -cantes de -e desinencial (disfarce, disfarces, disfarcemos)

89 -archar (3) term. os poucos v. da língua com essa term. são regulares

90 -arcir (1) term. o v. ressarcir, tido como defectivo (na $1^{\mathrm{a}}$ p.s.pres.ind. e, decorrentemente, no pres.subj., e, antes, em todas as f. rizotônicas), é hoje em dia regular (com a mudança do -cem -ç- antes de -o e - $a$ desinenciais, tipo ressarço, ressarçava)

91 -ardar (37) term. todos os v. da língua com essa term. são regulares

92 -arder (1) term. o v. arder é regular

93 -ardir (3) term. os v. encardir e desencardir são regulares

94 -arfar (4) term. os poucos v. da língua com essa term. são regulares

95 -argar (11) term. os v. da língua com essa term. são regulares, mas o - $g$ - se muda em -guantes de -e-(alargues etc.)

96 -argir (2) term. os v. espargir e despargir foram tidos como defectivos (sem a $1^{\text {a }}$ p.s.pres.ind. e sem o pres.subj., ou só conjugáveis nas f. arrizotônicas), mas modernamente estão regularizados, mudando o - $g$ - em - $j$ - antes de $-o$ - e $-a$ - desinenciais (esparjo, esparges, esparja etc.); apresentam tb. um segundo part.pas. esparso e desparso ${ }^{110}$

97 -arir (3) term. o v. guarir é defectivo na $1^{1}$ p.s.pres.ind. e no pres.subj.; os v. malparir e parir têm nas $1^{\mathrm{a}}$ p.s.pres.ind. malpairo e pairo e, decorrentemente, o pres.subj. malpaira e paira etc., regulares as demais f. ${ }^{111}$

98 -arjar (2) term. os poucos v. da língua com essa term. são regulares ${ }^{112}$

99 -arlar (4) term. os poucos v. da língua com essa term. são regulares ${ }^{113}$

100-armar (5) term. os poucos v. da língua com essa term. são regulares

101-arnar (7) term. os poucos v. da língua com essa term. são regulares

102-arnir (3) term. os v. escarnir, garnir e guarnir são tidos como defectivos, sem as f. rizotônicas ${ }^{114}$

103-arpar (9) term. os v. da língua com essa term. são regulares

104-arpir (1) term. o v. carpir é defectivo na $1^{\mathrm{a}}$ p.s.pres.ind. e, decorrentemente, no pres.subj.

quanto ao gosto, ao procedimento etc.", e "tornar-se homossexual”, na segunda acepção, esta pronominal) e abichar ("obter, conseguir (qualquer tipo de vantagem ou recompensa)").

${ }^{110}$ Como não há registro de desparso no dicionário, fica desconsiderada a indicação de um segundo particípio para despargir para efeito da análise feita neste trabalho.

111 Guarir é definido como "recuperar a saúde (de alguém ou a própria); sarar(-se), sanar(-se)") e malparir, como "ter um parto ruim").

${ }^{112}$ Os dois verbos são sarjar ("abrir sarja em; fazer incisão em”, sendo sarja "incisão superficial na pele para extrair sangue ou, no caso de um tumor, para extrair pus”) e tarjar.

${ }^{113}$ Um dos verbos é charlar ("conversar por mero passatempo, sem assunto determinado").

${ }^{114}$ Em garnir e guarnir, há remissão para guarnecer e, em escarnir, para escarnecer. 
105-arrar (47) term. todos os v. da língua com essa term. são regulares

106-arrer (2) term. o v. varrer (e derivados) é regular ${ }^{115}$

107-arrir (3) term. o v. barrir, metaforicamente conjugado, só é defectivo na $1^{\text {a }}$ p.s. pres.ind. e pres.subj.; o verbo garrir só é conjugado nas f. arrizotônicas ${ }^{116}$

108-artar (23) term. todos os v. da língua com essa term. são regulares

109-artir (11) term. o v. partir e seus der. são regulares

110-arvar (6) term. os poucos v. da língua com essa term. são regulares

111-arzir (2) term. os v. esparzir e desparzir são regulares ${ }^{117}$

112-asar (22) term. os v. da língua com essa term. são regulares

113-ascar (25) term. todos os v. da língua com essa term. são regulares, mas o $c$ muda em qu antes de $e$ (descasque, descasquemos etc.)

114-ascer (4) term. os v. nascer e pascer (e derivados) fazem na $1^{\mathrm{a}}$ p.s. do pres. do ind. -asço (e, conexo, o pres. do subj. -asça, -asças etc.), sendo regulares suas demais f. (pasço é tida como f. teórica, reputando-se o v. defectivo dela); para a pronúncia desta term., ver -scer ${ }^{118}$

115-asgar (3) term. os poucos v. da língua com essa term. são regulares, mas o - $g$ - muda em - guantes de -e-(engasguemos etc.)

116-asir (2) term. o v. asir e seu der. desasir só são conjugados nas f. arrizotônicas ${ }^{119}$

117-asmar (11) term. todos os v. da língua com essa term. são regulares; o v. pasmar só tem, canonicamente, o part. regular pasmado; ver, porém, pasmo

118-asnar (3) term. os poucos v. da língua com essa term. são regulares ${ }^{120}$

119-asnir (1) term. o v. grasnir no sentido metafórico é regular ${ }^{121}$

120-aspar (3) term. os poucos v. da língua com essa term. são regulares

121-assar (32) term. todos os v. da língua com essa term. são regulares

122-astar (33) term. todos os v. da língua com essa term. são regulares (gastar, entretanto, tem dois part. - gastado e gasto -, mas seu der. desgastar, só desgastado)

\footnotetext{
${ }^{115}$ Os dois verbos são varrer e barrer

$\left.{ }^{116} \mathbf{1}^{\mathbf{0}}\right)$ Barrir é definido como "emitir barritos", sendo barrito "o som vocal emitido pelo elefante e por alguns outros animais; barrido", e garrir, como "falar em excesso; tagarelar, matraquear". 20 Além dos verbos mencionados, há registro de esmarrir ("perder a seiva, o vigor; ressequir, desanimar"), que na tábua não se conjuga na $1^{a}$ p.s. pres.ind. e em todo o pres.subj. $3^{\circ}$ ) A descrição do comportamento do verbo garrir está comprometida pela redação: tal como está parece que, no sentido metafórico, o verbo não é conjugado na $1^{\mathrm{a}}$ p.s. pres.ind. e em todo o pres.subj. Para outros verbos com observação sobre a conjugação em sentido metafórico, os redatores não falam em defectividade: grasnir, p.ex., "no sentido metafórico é regular" conforme descrito em -asnir.

${ }^{117}$ Os dois verbos são esparzir (com remissão para espargir) e sua variante (desparzir).

${ }_{118} \mathbf{1}^{\text {}}$ ) Os redatoes não descrevem a defectividade de pascer e, na tábua, conjugam-se pascer e repascer em todas as formas, de modo que não se pode afirmar qual seria a conjugação do verbo pascer para os lexicógrafos.

${ }^{119}$ Os dois verbos são asir ("agarrar(-se), segurar(-se) com firmeza" na segunda acepção) e desasir ("fazer cair ou cair aquilo que estava asido, seguro; $\operatorname{soltar}(-\mathrm{se})$, desprender(-se)").

${ }^{120}$ Um dos verbos é grasnar ("emitir som (corvos e abutres); corvejar, crocitar").

${ }^{121}$ Em grasnir, há remissão para grasnar ("emitir som (corvos e abutres); corvejar, crocitar").
} 
123-astrar (21) term. os v. da língua com essa term. são regulares

124-atar (131) term. todos os v. da língua com essa term. são regulares

125-ater (10) term. o v. ater conjuga-se como ter, ver; os demais com essa term. são regulares ${ }^{122}$

126-atir (1) term. o v. latir é, metaforicamente, regular

127-atrar (4) term. o só v. da língua com essa term. (idolatrar) é regular

128-audar (0) term. os v. da língua com essa term. são regulares, isto é, mantêm mesmo nas f. rizotônicas o ditongo au: defraudo etc., descaudas etc., fraudem etc.; mas saudar (e ressaudar) tem variação nas f. arrizotônicas (sa-u-da-mos ou sau-da-mos) e hiato nas rizotônicas (saúdo, saúdas, saúda, saúdam, saúde, saúdes, saúdem) $)^{123}$

129-aular (0) term. o v. enjaular é regular e mantém em todas as f. o ditongo au já abaular, apaular, desembaular, embaular conjugam-se como saudar; ver -audar ${ }^{124}$

130-aurar (0) term. os poucos v. da língua com essa term. são regulares e mantêm o ditongo au em todas as f. ${ }^{125}$

131-aurir (2) term. os v. haurir e exaurir eram tidos como defectivos, sem a $1^{\mathrm{a}}$ p.s.pres.ind. e, decorrentemente, sem pres.subj.; modernamente, tendem a regularizar-se; exausto ocorre às vezes como segundo part.pas. de exaurir

132-ausar (0) term. os poucos v. da língua com essa term. são regulares e mantêm o ditongo -auem todas as f. ${ }^{126}$

133-autar (0) term. os v. da língua com essa term. são regulares e mantêm preservado em todas as f. o ditongo $-a u^{-127}$

134-avar (50) term. todos os v. da língua com essa term. são regulares

135-aver (4) term. o v. haver faz no pres.ind. hei, hás, há, havemos ou hemos, haveis ou heis, hão; o pres.subj. haja etc.; o rad. do perf. houve, donde houvera etc., houvesse etc., houver etc., sendo regulares as demais f.; o v. reaver, daquele der., só se conjuga nas f. em que haver apresenta a letra $v$ (reouve etc., inclusive); já precaver (e desprecaver) só se conjuga nas f. arrizotônicas $^{128}$

\footnotetext{
${ }^{122}$ Ater está contabilizado em ter.

${ }^{123} \mathrm{O}$ número entre parênteses é zero porque fraudar e saudar, e os outros três verbos em -audar estão contabilizados em -udar.

${ }^{124} \mathrm{O}$ número entre parênteses é zero porque enjaular e outros seis verbos em -aular estão contabilizados em -ulhar.

${ }^{125} \mathrm{O}$ número entre parênteses é zero porque deaurar ("cobrir com ouro ou algo similar"), instaurar, minotaurar (com remissão para minotaurizar, "tornar semelhante ao Minotauro") e restaurar estão contabilizados em -urar.

126 O numero entre parênteses é zero porque apausar ("promover pausa em"), causar e pausar estão contabilizados em -usar.

${ }^{127} \mathrm{O}$ numero entre parênteses é zero porque causar e outros cinco verbos em -ausar estão contabilizados em -usar.

${ }^{128}$ A expressão adverbial de contraposição "já" é indevida, pois não há diferença entre a defectividade de reaver e precaver (conjugados apenas nas formas arrizotônicas), embora a redação leve a crer que sim: "só se conjuga nas f. em que haver apresenta a letra v (reouve etc., inclusive)" e "só se conjuga nas f. arrizotônicas", respectivamente.
} 
136-avir (1) term. os v. com essa term., o próprio avir e contravir e desavir, conjugam-se como vir, $\operatorname{ver}^{129}$

137-avrar (7) term. todos os v. da língua com essa term. são regulares

138-axar (17) term. todos os v. da língua com essa term. (o $x$ é sempre chiante) são regulares

139-azar (21) term. todos os v. da língua com essa term. são regulares

140-azer (33) term. 1) fazer (e derivados como bem-fazer, contrafazer, desafazer, desfazer, esfazer, estupefazer, liquefazer ou liqüefazer, malfazer, perfazer, putrefazer, rarefazer, refazer, satisfazer, torrefazer, transfazer, tumefazer) tem no pres.ind. faço (donde pres.subj. faça etc.), fazes, faz, fazemos etc.; rad. do perf. fiz, fizeste, fez, fizemos etc. (donde fizera etc., fizesse etc., fizer etc.), part. feito, fut. farei etc., fut.pret. ou cond. faria etc.; 2) jazer (e adjazer, circunjazer, subjazer) é modernamente regular, salvo na $3^{\mathrm{a}}$ p.s.pres.ind. jaz; 3) prazer (aprazer, comprazer, desaprazer, descomprazer, desprazer, reaprazer, reprazer), salvo na $3^{\mathrm{a}}$ p.s.pres.ind. que faz praz, é regular, subsistindo, porém, no rad. do perf., a par da f. moderna regular prazi etc. (com prazera, prazesse, prazer etc.), a f. antiga prouve etc. (prouvera etc., prouvesse etc., prouver etc.); 4) trazer (destrazer, retrazer) tem no pres.ind. trago (donde todo o pres.subj. traga, tragas etc.), trazes, traz, trazemos, trazeis, trazem, perf. trouxe etc. (donde trouxera etc., trouxesse etc., trouxer etc.), fut. trarei etc. e fut.pret. ou cond. traria etc. ${ }^{130}$

141-ear (1094) term. de verbos da $1^{a}$ conj., dominantemente freqüentativos, em número notável (mais de 900 em meio a cerca de 10 mil da conj. em apreço); esta term. é fecunda ainda; tem irregularidade específica, a saber, nas f. rizotônicas o hiato $-e-a$ - se desfaz em $-e i-a$ - (ou -ei$e-)$, enquanto nas arrizotônicas a vogal de base rad. - $e$ - se faz vogal variável, de pronúncia flutuante/e:i/, razão por que, no vulg., há por vezes cruzamentos entre os v. em -ear e os em -iar; mas o padrão culto oferece extrema co-regularidade em todos os v. em causa; tome-se, como paradigma, o v. nortear: norteio, norteias, norteia, norteamos, norteais, norteiam; norteava etc.; norteei etc.; nortearei etc.; nortearia etc.; norteie, norteies, norteie, norteemos, norteeis, norteiem; norteasse etc.; nortear etc.; norteando; norteado - note-se certa tendência de usar a semivogal (na oralidade e na literalidade) em verbos que, sem ela, tendem a homofonizar-se com v. parônimos: afeiamos, para não confundir-se com afiamos; arreiais, para não confundir-se com arriais; enfeiastes, para não confundir-se com enfiastes; os v. em -ear são semanticamente equivalentes aos em -ejar (ver); a língua, contudo, tem feito opção por um dos dois, isto é, o v. freqüentativo em -ear (ou inversamente em -ejar) nem sempre é sinonímico do v. freqüentativo em -ejar (ou inversamente em -ear); ver -iar ${ }^{131}$

142-ebar (6) term. os poucos v. da língua com esta term. têm a vogal -e-, nas f. rizotônicas, aberta: deba, debem, desensebas, desensebe, ensebes, ensebo, gebam, rebe etc.

143-eber (11) term. os v. com esta term. são, em princípio, regulares, tendo nas f. rizotônicas fechado o -e- na $1^{\mathrm{a}}$ p.s. do pres.ind. (percebo) e nas conexas do pres.subj. (perceba, percebas, perceba, percebam) e aberto nas restantes f. rizotônicas (percebes, percebe, percebem); há variações mesmo cultas regionais em que estas últimas $\mathrm{f}$. abertas se preservam fechadas: nas

\footnotetext{
${ }^{129}$ O número entre parênteses é um porque, estando avir, contravir, desavir e reavir ("voltar a avir(-se) com; tornar(-se) a avir; reconciliar(-se)") contabilizados em vir, esta terminação corresponde apenas ao verbo desenxavir (com remissão para desenxabir), que na tábua é conjugado regularmente em todas as formas.

${ }^{130}$ Não há registro de reaprazer e reprazer (derivados de prazer) nem de retrazer (derivado de trazer).

${ }^{131}$ Note-se que os lexicógrafos registram 1094 verbos em -ear, dentre 13209 verbos em -ar (e não "mais de 900 em meio a cerca de 10 mil da conj. em apreço").
} 
f. arrizotônicas, o -e- de base tende à harmonização vocálica com a vogal tônica, constituindo, assim, uma vogal variável: percebia/percibia, mas percebemos (em Portugal faz-se -ereduzido)

144-ebrar (13) term. os v. da língua com esta term. têm a vogal -e-, nas f. rizotônicas, aberta: alquebro, azebras, celebra, concelebram, descerebre, encerebres, quebre, requebrem etc.

145-ecar (55) term. os v. da língua com esta term. têm a vogal -e-, nas f. rizotônicas, aberta, além de trocarem o -c- em -qu- antes da vogal -e- desinencial: abeco, abibliotecas, abonecas, abotecam, amoleque, amoqueques, amunheque, defequem etc.

146-eçar (18) term. os v. da língua com esta term. têm a vogal -e-, nas f. rizotônicas, aberta, além de trocarem o $-\varsigma_{-}$- pelo $-c$ - antes da vogal -e- desinencial: adereço, apreças, começa, descabeçam, desempece, empeces, encabece, enderecem etc.

147-ecer (288) term. de v. latinos em -escěre (ver -escer); sua fecundidade como incoativo ficou cedo manifesta em port. nos v. da $2^{\mathrm{a}}$ conj., fecundidade que perdurou na língua por largo lapso de tempo, originando grande número de tais v. com radicais vulg. e vern.: enquanto os v. em -escer somam cerca de 53, os v. em -ecer montam a cerca de 220 são em princípio regulares, tendo, nas f. rizotônicas, fechado o $-e$ - na $1^{\mathrm{a}} \mathrm{p} . \mathrm{s}$. do pres.ind. (aborreço, e nas conexas do pres.subj. aborreça, aborreças, aborreça, aborreçam) e aberto nas demais (aborreces, aborrece, aborrecem); o -c- muda-se em -ç- antes do - $a$ - desinencial, como se vê acima; há variações, mesmo cultas, regionais em que estas últimas f. (abertas) se preservam fechadas $^{132}$

148-echar (24) term. 1) os v. com esta term. conexos com subst. em -echo /ê/ têm o -erizotônico fechado: apetrecho, barbechas, bochecha, desfecham, endeche, entreches, entrefeche, pelechem, repeches etc.; 2) os conexos com subst. em -echa /é/ têm o -erizotônico aberto: aflecho, afrechas, brecha, desfrecham, embreche, encalameches, esmeche, flechem, frecho, mechas, pecha etc.; no coloquial informal, há a tendência de v. do grupo (1) passarem ao (2) ${ }^{133}$

149-ecrar (3) term. os v. da língua com esta term. têm o -e-aberto nas f. rizotônicas: execro, obsecras etc. ${ }^{134}$

150-ectar (14) term. os v. da língua com esta term. têm o -e- aberto nas f. rizotônicas (e preservam o grupo consonântico impróprio): detecto, expectas, infecta, prospectam, umecte etc.

\footnotetext{
${ }^{132}$ Note-se que os lexicógrafos registram 288 (e não "cerca de 220") verbos em -ecer bem 67 (e não“cerca de 53 ”) em -escer.

${ }^{133}$ De acordo com o critério proposto, dez verbos pertencem ao grupo 1 - apetrechar, barbechar, bochechar, desfechar, endechar, entrechar, entrefechar, fechar, pelechar e petrechar -, pois são cognatos de substantivos em cujo verbete há indicação de timbre fechado para a vogal - apetrecho, barbecho, bochecho, desfecho, decho, entrecho, fecho, pelecho e petrecho -; nove, ao grupo 2 - amechar, aflechar, afrechar, desfrechar, encalamechar, esmechar, flechar, frechar e mechar -, pois são cognatos de substantivos em cujo verbete há indicação de timbre aberto para a vogal - flecha, frecha e mecha. Fica sem solução o timbre da vogal em cinco verbos - brechar, desembrechar, embrechar, pechar e repechar -, pois são cognatos de substantivos em cujo verbete não há indicação do timbre da vogal - brecha, embrechado, embrecho e brecha e pecha.

${ }^{134}$ Obsecrar é definido como "pedir encarecidamente; suplicar, implorar".
} 
151-ectir (4) term. todos os v. da língua com esta term. (deflectir, flectir, genuflectir e inflectir) são var. de formas em -etir, conjugando-se igualmente, mas, nestes casos, preservando a seqüência consonântica $-c t$ - intacta $^{135}$

152-edar (45) term. os v. da língua com esta term. têm o -e-aberto nas f. rizotônicas: alamedo, alevedas, almoeda, amoedam, aquede, arredes, arremede, azedem; o v. apiedar (e despiedar e desapiedar) muda tradicionalmente esse - $e$ - rizotônico em -a-: apiado, despiades, desapiadem etc., mas hoje em dia abona-se tb. apiedo etc.; o v. redar conjuga-se como dar, no sentido de 'dar novamente', e como o padrão acima, no sentido de 'jogar rede'136

153-eder (17) term. os poucos v. da língua com esta term. são em princípio regulares, com o -efechado na $1^{\mathrm{a}}$ p.s. do pres.ind. (cedo, e nas f. conexas do pres.subj. ceda, cedas, ceda, cedam) e aberto nas restantes f. rizotônicas (cedes, cede, cedem)

154-edir (18) term. os v. da língua com esta term. pertencem ao grupo 1) de -gredir (agredir, progredir, regredir, transgredir), com a mudança de - $e$ - em - $i$ - nas f. rizotônicas - tipo agrido (e decorrentemente agrida, agridas, agrida, agridamos, agridais, agridam), agrides, agride, agridem (mas agredimos, agredis imper. agride, agridam, agredi, agridam) -, sendo as demais regulares; ao grupo 2) de pedir (e derivados) e medir (e derivados) (comedir, desimpedir, despedir, expedir, impedir, reexpedir, remedir, repedir), com a $1^{\mathrm{a}} \mathrm{p} . \mathrm{s}$. do pres.ind. em -eço (donde pres. do subj. -eça, -eças etc.), -edes, -ede, -edem (todas essas f. com -eaberto), sendo todas as demais f. regulares ${ }^{137}$

155-edrar (10) term. os v. da língua com esta term. têm o -e- aberto nas f. rizotônicas: apedro, desempedras, desmedra, empedram, encedre, expedres, medre, redrem etc.

156-efar (4) term. os poucos v. da língua com esta term. têm aberto o - $e$ - nas $\mathrm{f}$. rizotônicas: atarefo, blefas, ensanefa etc. ${ }^{138}$

157-egar (129) term. os v. da língua com esta term. têm aberto o - e- nas f. rizotônicas, além de mudarem o -g- em -gu- antes de -e- desinencial: ablego [...] etc.; chegar (achegar, desachegar, conchegar, desaconchegar) têm, entretanto, o -e- rizotônico fechado: achego, achegues, chegas, conchegam, desachega, desaconchegue etc. ${ }^{139}$

158-eger (9) term. os poucos v. da lígua com esta term. são em princípio regulares, com o -efechado na $1^{\text {a }}$ p.s. do pres.ind. (rejo, e nas conexas do pres.subj. reja, rejas, reja, rejam) e aberto nas restantes f. rizotônicas (reges, rege, regem); o -g-muda-se em -j- antes de -o- ou $-a$ - desinenciais

\footnotetext{
${ }^{135}$ Flectir é definido como "dispor em curva, em flexão; dobrar, curvar, voltear" e inflectir, como "inclinar, formando uma curva algo acentuada"; em deflectir, há remissão para defletir ("ocasionar alteração ou desvio da posição natural de (alguém ou algo) para (um dos lados); deflectir, deflexionar, desviar").

$\left.136 \mathbf{1}^{\mathbf{0}}\right)$ Em alevedar, há remissão para levedar e aquedar é definido como "tornar(-se) quieto; aquietar(-se), sossegar(-se)". $\mathbf{2}^{\circ}$ ) O verbo redar está contabilizado em dar.

${ }^{137}$ Note-se que "grupo de -gredir" (segmento final de verbos como agredir) se opõe a "grupo de pedir" (verbo, e não segmento final de verbos).

${ }^{138}$ Ensanefar é definido como "guarnecer, enfeitar com sanefa(s)", sendo sanefa, "larga tira de tecido que se coloca na parte superior da cortina ou reposteiro, nas vergas das janelas etc., ger. rematada com franja ou galão".

$\left.139 \mathbf{1}^{\circ}\right)$ Ablegar é definido como “afastar para longe, mandar embora; banir, exilar, desterrar”. $\mathbf{2}^{\mathbf{0}}$ ) Desachegar é definido como "pôr(-se) afastado de (o que estava achegado, próximo); separar(-se), afastar(-se); em conchegar, há remissão para aconchegar.
} 
159-eglar (1) term. o só v. da língua com essa term. tem o -e-aberto nas f. rizotônicas: arreglo, arreglas, arreglam, arregle, arreglem etc.

160-egmar (2) term. os únicos (deflegmar e desflegmar) v. da língua com esta term. têm aberto o -e- rizotônico (e preservam intacta a seqüência consonântica): deflegmo, desflegmas; deflegme, desflegmes etc. ${ }^{140}$

161-egrir (1) term. o v. denegrir (que alterna com denigrir, ver -igrir) muda o - e- em - $i$ - nas $\mathrm{f}$. rizotônicas - denigro (donde todo o pres.subj. denigra etc.), denigres, denigre, denigrem, imper. denigre, denigra (denegri), denigram, sendo todas as demais f. regulares

162-eguar (2) term. o v. da língua com esta term. (atreguar) tem o -u-tônico nas f. rizotônicas: atreguo, atreguas, atregua, atreguam; atregúe, atregúes, atregúe, atregúem; ver tb. -aguar, in fine $e^{141}$

163-eguir (7) term. o v. seguir (e seus der. conseguir, desseguir, perseguir, prosseguir, retrosseguir, subseguir) tem a $1^{\text {a }}$ p.s. do pres.ind. sigo (donde todo o pres.subj. siga, sigas etc.), e as restantes f. rizotônicas com -e- aberto (segues, segue, seguem; imper. segue; como se vê acima, o - $g u$ - muda em - $g$ - antes de - $o$ - e - $a$ - desinenciais

164-eiçar (0) term. os poucos v. da língua com esta term. preservam sempre o fechamento do ditongo -ei- (e o -ç-se muda em -c-antes de -e-desinencial): desbeicem, desbeiço, embeiças, esbeiçam, esbeicemos etc. ${ }^{142}$

165-eifar (0) term. o só v. da língua com esta term. preserva o fechamento do timbre do ditongo -ei- em todas as f.: ceifo, ceifas, ceifam, ceife, ceifava, ceifará etc. ${ }^{143}$

166-eigar (0) term. os poucos v. da língua com esta term. preservam o timbre fechado do ditongo - $e$ - em todas as f. (mudando - $g$ - em -gu- antes de -e-desinencial): amanteigo, ameigas, desarreiga, entaleigam, leigue, amanteigues, ameigue, desarreiguem etc.; em certas áreas, a redução desse ditongo a $-e$ - nas $f$. arrizotônicas (amantegar) gera um - $e$ - aberto rizotônico: amantego, amantegas etc., não canônico ${ }^{144}$

167-eijar (0) term. sempre com -ei- fechado, são regulares todos os v. com esta term.: aleijo, beijas, enqueija, queijamos, rebeije, rebeijemos etc.; em certas áreas, a redução do -ei- a -efechado (alejar, por aleijar) nas f. arrizotônicas acarreta timbre aberto das f. rizotônicas (alejo, alejas etc.), não canônico ${ }^{145}$

\footnotetext{
${ }^{140}$ Em deflegmar (be como em sua variante desflegmar), há remissão para retificar (cujas acepções não se aplicam aos dois verbos) mas são indiretamente definidos em deflegmação ("ato ou efeito de deflegmar, de separar a parte aquosa de uma substância").

${ }^{141}$ Além do verbo mencionado, há registro de eguar (“andar sem rumo certo; bestar, errar"). $\mathbf{2}^{\circ}$ ) A remissão para "-aguar, in fine" não se justifica, pois a conjugação descrita lá não coincide com a descrita aqui.

${ }^{142} \mathbf{1}^{\circ}$ ) O número entre parênteses é zero porque desbeiçar ("ferir ou mutilar o(s) beiço(s) de"), desembeiçar ("eliminar a aparência embeiçada de"), embeiçar ("tornar(-se) cativo por amor ou sedução; enamorar(-se), encantar(-se), apaixonar(-se); trazer ou ser trazido pelo beiço") e esbeiçar ("estender, esticar ou fazer descair (os beiços)") estão contabilizados em -içar.

${ }^{143} \mathbf{1}^{\circ}$ ) O número entre parênteses é zero porque ceifar e aceifar estão contabilizados em -ifar.

$144 \mathbf{1}^{\circ}$ ) O número entre parênteses é zero porque amanteigar e outros seis verbos em -eigar estão contabilizados em -igar. $\mathbf{2}^{\mathbf{0}}$ ) Em desarreigar, há remissão para desarraigar; entaleigar é definido como "colocar em taleiga ('saco')", e leigar, "transformar(-se) em leigo, em laico; laicizar, secularizar(-se)".

${ }^{145} \mathrm{O}$ número entre parênteses é zero porque beijar e outros cinco verbos em -eijar estão contabilizados em -ijar.
} 
168-eimar (0) term. os v. com esta term. são regulares: aboleimo, aceimas, afleima, afreimamos, atoleimais, infuleimam, queime, requeimes, teime, teimem etc., mantendo sempre fechado o timbre do ditongo $-e i^{146}$

169-einar (0) term. os poucos v. da língua com esta term. são regulares: deceino, reinas, treinas, deceinamos, reinais etc. ${ }^{147}$

170-eirar (0) term. todos os v. da língua com esta term. são regulares, preservando o timbre fechado do ditongo -ei- tanto nas f. arrizotônicas quanto nas rizotônicas: abadeiro, abarreiras, abeira, abrasileiramos, acavaleirais, aceiram, aceleire, aleires, aligeire, alqueiremos, amadeirais, amaneirem etc.; um grande número de v. de uso corrente desse grupo é equiparado aos v. em -erar, com as decorrentes modificações na conj., não canônicas (intero, interas, intera, interam, intere, interem etc., com -e- aberto, em lugar de inteiro, inteiras, inteira, inteiram, inteire, inteires, inteirem etc. $)^{148}$

171-eitar (0) term. os v. da língua com esta term. são todos regulares, preservando o timbre fechado do ditongo -ei-, tanto nas f. arrizotônicas quanto nas rizotônicas; aceitar, porém, além do part.pas. regular, tem aceito e tb. aceite; e sujeitar tem o regular e sujeito $^{149}$

172-eivar (0) term. os poucos v. da língua com esta term. são regulares, preservando o timbre fechado do ditongo -ei- em todas as f. ${ }^{150}$

173-eixar (0) term. os v. da língua com esta term. são regulares, preservando o timbre fechado do ditongo - $e i$ - em todas as f. ${ }^{151}$

174-eizar (0) term. os dois v. que consignam esta term. (homogeneizar e heterogeneizar) fazem, nas f. rizotônicas, hiato típico: homogeneizo, heterogeneizas, homogeneiza, heterogeneízam, homogeneize etc. ${ }^{152}$

175-ejar (270) term. de verbos da $1^{\mathrm{a}}$ conj., que podem ser agrupados em: 1) verbos de form. diversa (arpejar [it.]; azulejar [ár.]; desejar [lat.]; solfejar [it.]); 2) verbos em que -ejar, com caráter sufixal, lhes atribui aspecto freqüentativo (alvejar, bacorejar, espacejar, farejar, gorgolejar, pestanejar, praguejar, velejar etc.); os muitos v. da língua com esta term. são regulares, até porque o timbre fechado do -e- se preserva tanto nas f. arrizotônicas quanto nas f. rizotônicas: alveja, branquejo, desejais, espacejemos, farejamos, gorgoleje, mercadejes, pestanejam, planejemos, pragueje, rouquejeis, solfejem etc

\footnotetext{
${ }^{146} \mathrm{O}$ número entre parênteses é zero porque teimar e outros catorze verbos em -eimar estão contabilizados em -imar.

${ }^{147} \mathbf{1}^{\mathbf{0}}$ ) O número entre parênteses é zero porque reinar e outros oito verbos em -einar estão contabilizados em -inar. $\mathbf{2}^{\mathbf{0}}$ ) Diferentemente do que fazem em -izar, aqui os redatores não observam a acentuação gráfica nas formas rizotônicas do radical do presente de cafeinar e descafeinar.

${ }^{148} \mathbf{1}^{\mathbf{0}}$ ) O número entre parênteses é zero porque os 160 verbos em -eirar estão contabilizados em -irar. $\mathbf{2}^{\mathbf{0}}$ ) Depois de observarem que "todos os v. da língua com esta term." preservam "o timbre fechado do ditongo -ei- tanto nas f. arrizotônicas quanto nas rizotônicas", os redatores afirmam contraditoriamente que "um grande número de v. de uso corrente desse grupo é equiparado aos v. em -erar [...] com -e-aberto".

${ }^{149} \mathrm{O}$ número entre parênteses é zero porque deitar e outros 49 verbos em -eitar estão contabilizados em -itar.

${ }^{150} \mathrm{O}$ número entre parênteses é zero porque enseivar ("dotar ou ser dotado de seiva (esp. vegetal)") e outros três verbos em -eivar estão contabilizados em -ivar.

${ }^{151} \mathrm{O}$ número entre parênteses é zero porque os 21 verbos em -eixar estão contabilizados em -ixar.

${ }^{152} \mathbf{1}^{\mathbf{0}}$ ) O número entre parênteses é zero porque homogeneizar e heterogeneizar estão contabilizados em -izar (assim como ateizar, europeizar e plebeizar, descritos lá). $\mathbf{2}^{\circ}$ ) A observação de que o hiato é "típico" mostra que esses dois verbos deveriam ter sido incluídos em -izar, tanto quanto o foram europeizar e plebeizar e, portanto, o verbete -eizar não deveria ter sido estabelecido.
} 
176-elar (247) term. todos os v. da língua com esta term. têm nas f. rizotônicas o - e- aberto: abroquelo, acautelas, desmantela, desfarele, peles, embarrelem etc.

177-eler (3) term. os v. reler, treler, tresler são der. de ler; ver, e como este se conjugam; exceler (que alterna com excelir), para uns não tem a $1{ }^{\mathrm{a}}$ p.s. do pres.ind., donde, decorrentemente, não tem o pres.subj., enquanto para outros é regular (com excelo, donde excela, com -e- fechado), sendo com -e-aberto as restantes f. rizotônicas (exceles, excele, excele) $)^{153}$

178-elhar (65) term. todos os v. da língua com esta term. são regulares e mantêm o -e- fechado mesmo nas f. rizotônicas: aconselho, aparelhas, assemelha, avermelham, emparelhe, espelhes, semelhem; entretanto, grelhar (por influência do timbre aberto do subst. grelha) abre $\mathrm{o}$-e-nas f. rizôtonicas; ver -lhar quanto à sua morfologia

179-elir (12) term. há dois grupos de v. com esta term.: 1) o de delir e excelir (este alterna com exceler, ver -eler), sem a $1^{\mathrm{a}}$ p.s. do pres.ind. (e, assim, sem o pres.subj. todo) e com o - $e$ aberto nas f. rizotônicas restantes; 2) o de compelir, convelir, expelir (com segundo part. expulso), impelir, propelir, repelir e revelir, com o -e- feito - $i$ - na $1^{\mathrm{a}} \mathrm{p}$.s. do pres.ind. (compilo, donde todo o pres.subj. compila etc.) e o -e-aberto em todas as restantes f. rizotônicas (compeles, compele, compelem); com relação a delir, cumpre considerar que Amador Arrais usa da f. dile na $3^{\mathrm{a}}$ p.s. do pres.ind., que presume o paradigma dilo, diles, dile, delimos, delis, dilem, pres.subj. dila, dilas etc., no sXVII ${ }^{154}$

180-eltrar (2) term. os dois v. da língua com essa term. (enfeltrar e feltrar) abrem o timbre do -enas f. rizotônicas (feltro, enfeltras etc.) ${ }^{155}$

181-elvar (4) term. os poucos v. da língua com esta term. abrem o timbre do - e- nas f. rizotônicas (arrelvo, desrelvas, relva etc. $)^{156}$

182-emar (24) term. os v. da língua com esta term. são, em princípio, regulares, mas o timbre do $-e-$, por ser antenasal, é aberto ou fechado (segundo as regiões) nas f. rizotônicas

183-embrar (8) term. todos os v. da língua com esta term. são regulares

184-emer (9) term. os v. da língua com esta term. são regulares; o -e-, nas f. rizôtonicas, varia de aberto a nasalado, segundo as regiões

185-emir (4) term. dos v. com esta term. 1) remir só se conjuga nas f. arrizotônicas, moderadamente, sendo as rizotônicas supridas pelo regular redimir 2) acupremir, fremir, premir, só são defectivos na $1^{\mathrm{a}}$ p.s. do pres.ind. e, decorrentemente, todo o pres.subj.; há as f. alternativas, fremer e premer que se conjugam como em -emer, ver

186-empar (3) term. os poucos v. da língua com esta term., inclusive empar, são regulares ${ }^{157}$

\footnotetext{
${ }^{153} \mathbf{1}^{\mathbf{0}}$ ) Os verbos reler e treler estão contabilizados em ler. $\mathbf{2}^{\mathbf{0}}$ ) É indevida a inclusão de tresler (devidamente mencionado em -esler) na lista de verbos em -eler. $3^{\circ}$ ) Além de exceler ("destacar-se ou salientar-se muito de outros; ser excelente; excelir"), há registro de sobreexceler e sobrexceler.

${ }^{154}$ Além dos verbos mencionados, há registro de amarelir, conjugado como os verbos do "grupo 2"; e relir (com remissão para rir), declarado "forma antiga não-conjugável pelos padrões atuais".

${ }^{155}$ Feltrar é definido como "guarnecer ou cobrir de feltro ('tecido'); enfeltrar" e sua variante enfeltrar, como "transformar em feltro ('tecido'); feltrar".

156 Arrelvar é definido como "cobrir(-se) ou ornar(-se) de relva" e relvar, como "cobrir(-se) de relva; enrelvar(-se)", não havendo registro de desrelvar.

${ }^{157}$ Empar é definido como "sustentar (uma videira, parreira, feijoeiro etc.) por meio de varas ou estacas".
} 
187-emplar (1) term. os poucos v. da língua com esta term. são regulares ${ }^{158}$

188-enar (63) term. os v. da língua com esta term. são, em princípio, regulares, mas o timbre do -e-, por ser antenasal, é aberto ou fechado nas f. rizotônicas, segundo as regiões

189-encar (5) term. os poucos v. da língua com esta term. são regulares, mas trocam o - c- por -qu- antes de -e-desinencial (desencrenques etc.)

190-ençar (4) term. o v. diferençar é regular, mas troca o -ç- em -c-antes de -e- desinencial (diferences etc.); quanto a diferenciar, seu sinônimo, ver -iar ${ }^{159}$

191-encer (6) term. os v. da língua com esta term. são regulares, mudando o $-c$ - em -ç- antes de -o- e- $a$-desinenciais (tipo vencer:venço:vença)

192-encher (4) term. o v. encher e seus der. são regulares

193-endar (25) term. os v. da língua com esta term. são regulares

194-ender (65) term. os v. da língua com esta term. são regulares; alguns, além do part. regular (tipo acendido), têm um segundo, irregular, de preferência us. com os v. ser e estar e demais v. de estado (aceso, apenso, distenso, propenso, suspenso), além das funções adjetivas de $\operatorname{ambos}^{160}$

195-endrar (5) term. os poucos v. da língua com esta term. são regulares

196-engar (20) term. os poucos v. da língua com esta term. são regulares, mas trocam o - $g$ - por -gu- antes de -e-desinencial (derrengues etc.)

197-enhar (22) term. de v. de $1^{\text {a }}$ conj., conexos com nomes em -enha ou -enho, numa relação de 'ação; ato/agente/fato' [...]; os v. com esta term. são regulares, embora o timbre - $e$ - nas f. rizotônicas varie de aberto a fechado nasal, segundo as regiões

198-enhir term. (1) o v. renhir só se conjuga nas f. arrizotônicas

199-enir (7) term. há dois grupos de v.: 1) manutenir e lenir, que só se conjugam nas f. arrizotônicas, e 2) desprevenir, devenir, fretenir (metaforicamente), prevenir, que trocam o -e- em - $i$ - nas f. rizotônicas - -ino, -ines, -ine (-enimos, -enis), -inem -, donde todo o pres.subj. (-ina, -inas, -ina, -inamos, -inais, -inam $)^{161}$

200-ensar (24) term. os v. da língua com essa term. são regulares

201-entar (207) term. de verbos da $1^{\mathrm{a}}$ conj., com o el. -ent- do part.pres. + -a-, vogal temática da $1^{a}$ conj. $+-r$ desin. verb. do inf.; ocorre em v. ditos causativos, isto é, de v. cog. de outros v. mas que semanticamente se distinguem dos primitivos por se associarem à idéia de motivação causal do primitivo $[. .$.

202-entir (14) term. todos os v. com essa term. fazem a $1^{\text {a }}$ p.s.pres.ind. -into (donde todo o pres.subj. -inta, -intas, -inta, -intamos, -intais, -intam); todas as demais f. são regulares

\footnotetext{
${ }^{158} \mathrm{O}$ verbo único é contemplar.

${ }^{159}$ A existência de uma variante em -iar do verbo diferençar é fato isolado e só mereceria menção no verbete dos dois verbos.

${ }^{160}$ Apender é definido como "juntar (uma coisa) a (outra); anexar" e propender, como "pender ou inclinar-se para (a frente ou para um dos lados)".

161 Além dos verbos mencionados, há registro de revenir (“aquecer (peça esp. de aço, previamente temperado ou normalizado), a uma temperatura abaixo da faixa de transformação, a fim de ampliar-lhe a durabilidade e a tenacidade"), que faz parte do grupo " 2 ".
} 
203-entrar (11) term. os v. da língua com essa term. (inclusive entrar) são regulares

204-enzer (2) term. o v. benzer e der., rebenzer (sem falar dos potenciais desbenzer, trebenzer, transbenzer etc.), são regulares; há um part. irregular, bento, com verbos de estado (tendo sido benzido, tendo sido bento)

205-epar (9) term. os v. da língua com essa term. abrem o -e- nas f. rizotônicas (decepo, desencepas, destrepa, discrepam, encepe, estrepes, increpe, trepem etc.)

206-eptar (3) term. os poucos v. da língua com essa term. são regulares, com o - e- aberto nas f. rizotônicas e a preservação da seqüência consonântica -pt-: intercepto, receptas, repta etc. ${ }^{162}$

207-equar (2) term. os poucos v. da língua com essa term. (adequar, coadequar, inadequar) são tidos como conjugáveis, regularmente, só nas f. arrizotônicas; modernamente, porém, ocorrem f. rizotônicas segundo dois padrões - adéquo/adequo, adéquas/adequa etc. ${ }^{163}$

208-equir (1) term. o só v. da língua com essa term., ressequir, conjuga-se apenas nas f. arrizotônicas

209-er (797) term. 1) ocorre no inf. de todos os v. port. da $2^{\mathrm{a}}$ conj. (cerca de 668), term. composta da vogal temática $-e-$, da $2^{a}$ conj., + a desin. $-r$ do inf.; 2) há nela os segg. v. monossilábicos no inf. pessoal: crer, ler, ser, ter e ver; 3) com essa term. -er /ê/ não há subst. em port. (alijados pelo poder dessa conj.), salvo os inf. mesmos substv. (o poder, o saber, o crer, o dever, o haver etc.) ou f. compostas com eles (o bel-prazer, o bem-fazer, o de-comer; 4) o v. viger é da $2^{\mathrm{a}}$ conj. (e não vigir) ${ }^{164}$

210-erar (151) term. todos os v. da língua com essa term. são regulares, mas com o -e-aberto nas f. rizotônicas (abebero, adulteras, altera, blateram, cancere, depauperes, desaglomere, esmerem etc.)

211-erbar (7) term. os poucos v. da língua com essa term. são regulares, mas com o -e- de timbre aberto nas f. rizotônicas (acerbo, assoberbas, averba, desacerbam, desaverbe, exacerbes etc.)

212-ercar (8) term. os poucos v. da língua com essa term. têm o - e- aberto nas f. rizotônicas e o -c- mudado em -qu-, antes de -e-desinencial (acerco, altercas, cerca, descercam, enxerque, esterques, merques etc.)

213-erçar (3) term. os poucos v. da língua com essa term. têm o - e- aberto nas f. rizotônicas e o -ç- mudado em -c- antes de -e-desinencial (alicerço, alicerce, terças, terces etc.) ${ }^{165}$

214-ercer (1) term. o v. exercer faz na $1^{\text {a }}$ p.s.pres.ind. exerço (donde pres.subj. exerça, exerças etc., com - $e$ - fechado nas f. rizotônicas), regularizando-se nas demais exerces, exerce, exercem (com - $e$ - aberto); as f. arrizotônicas são totalmente regulares

215-erdar (6) term. os v. da língua com essa term. têm o -e-aberto nas f. rizotônicas (co-herdo, deserdas, enlerda, exerdem, herde, deserdem etc.)

\footnotetext{
${ }^{162}$ Reptar é definido como "manter oposição a" (em ${ }^{1}$ reptar) e "locomover-se de rastos; arrastar-se" (em ${ }^{2}$ reptar).

${ }^{163}$ Não há registro de co-adequar.

${ }^{164} \mathbf{1}^{\mathbf{}}$ ) O número entre parênteses é zero porque os 797 verbos (e não "cerca de 668") estão contabilizados nas terminações correspondentes a verbos da segunda conjugação. $\mathbf{2}^{\mathbf{0}}$ ) A observação de que “o v. viger é da $2^{\mathrm{a}}$ conj. (e não vigir)" caberia em viger (com remissão para -iger, onde o verbo é devidamente mencionado com relação à sua defectividade).

${ }^{165}$ Terçar é definido como "mesclar (três substâncias, componentes, elementos etc.) em partes iguais".
} 
216-erder (2) term. os v. perder e disperder fazem na $1^{\mathrm{a}}$ p.s.pres.ind. -erco (donde todo o pres.subj. -erca, -ercas, -erca, -ercamos, -ercais, -ercam, com -e- fechado nas f. rizotônicas) e com -e- aberto nas restantes f. rizotônicas - -erdes, -erde, -erdem; todas as demais f. são regulares ${ }^{166}$

217-erer (8) term. o v. querer e seus der. (bem-querer, desquerer, maisquerer, malquerer, requerer) se conjugam: $1^{\mathrm{a}}$ p.s.pres.ind. quero, com -e- aberto (embora o pres.subj. todo seja queira, queiras etc.), mas requerer faz requeiro (e, decorrentemente, requeira etc.); as demais f. rizotônicas são com -e- aberto: queres, quer (ou quere), querem; todas as demais f. são regulares, salvo o part. dúplice de bem-querer e malquerer, bem-querido e benquisto, malquerido e malquisto

218-ergar (11) term. os poucos v. com essa term. na língua têm o -e-aberto nas f. rizotônicas e a mudança do - $g$ - em -gu- antes do -e-desinencial (alberga, avergas, desenverga, envergam, enxergue, postergues, verguem etc.)

219-erger (4) term. os v. absterger e asperger são regulares, com a alternância vocálica de -efechado, em asperjo e absterjo, e aberto, em absterges, asperge, abstergem etc.; notar a mudança de - $g$ - em - $j$ - antes do - $o$ - e - $a$ - desinenciais (absterjo; absterja etc.) ${ }^{167}$

220-ergir (9) term. os v. 1) aspergir, convergir, divergir fazem a $1^{\text {a }}$ p.s.pres.ind. em -irjo (donde o pres.subj. -irja, -irjas etc.), regularizando-se nas demais f., que, nas rizotônicas, têm o -eaberto; 2) detergir, emergir, imergir e submergir (que se preconizava sem a $1^{\mathrm{a}} \mathrm{p} . \mathrm{s}$.pres.ind. e, assim, sem o pres.subj.) modernamente tendem a fazer -erjo (donde -erja, -erjas etc.), regularizando-se nas demais, com o - e- aberto nas f. rizotônicas; salvo para detergir, o part. é abundante, com o irregular em -erso ${ }^{168}$

221-erguer (5) term. o v. erguer e seus der. faz na $1^{\text {a }}$ p.s.pres.ind. ergo (com -e-fechado, donde todo o pres.subj. erga etc.), e já com -e- aberto nas f. rizotônicas (ergues, ergue, erguemos, ergueis, erguem); todas as demais f. são regulares; notar a mudança do - gu- em - $g$ - antes do -o- e- $a$ - desinenciais ${ }^{169}$

222-erir (35) term. todos os v. com essa term. (alguns de uso raro) fazem a $1^{\mathrm{a}} \mathrm{p}$.s. do pres.ind. em -iro (donde o pres.subj. em -ira etc.), regularizando-se nas demais f., que têm o - $e$ - aberto nas f. rizotônicas

223-erlar (2) term. os dois v. da língua com essa term. (emperlar, perlar) abrem o -e- nas f. rizotônicas ${ }^{170}$

224-ermar (7) term. os v. da língua com essa term. têm o -e-aberto nas f. rizotônicas (apalermo, atermas, desenferma, enferma, erme, mermes, palermem etc.)

225-ernar (35) term. os v. da língua com esta term. têm o -e-aberto nas f. rizotônicas (aderno, alternas, amoderna, atabernam, ataverne, badernes, cerne, confraternem, consternem etc.)

\footnotetext{
${ }^{166}$ Disperder é definido como "pôr a perder; arruinar, destruir".

${ }^{167}$ Absterger é definido como "retirar material putrefato de (ferimentos); limpar" e, em asperger, há remissão para aspergir.

${ }^{168}$ Além dos verbos mencionados, há registro de cergir, com remissão para cerzir, e reimergir, que faz parte do grupo " 2 ".

${ }^{169}$ É indevida a inclusão de erguemos e ergueis na lista de formas rizotônicas "com -e- aberto".

${ }^{170}$ Perlar é definido como "dar formato ou aparência de pérola a; emperlar, emperolar" e sua variante emperlar, como "guarnecer(-se) ou adornar(-se) com pérolas".
} 
226-ernir (6) term. os poucos v. da língua com esta term. são tidos como conjugáveis só nas f. arrizotônicas, com tendência a admitirem as rizotônicas em -ernes, -erne e -ernem

227-errar (33) term. todos os v. da língua com esta term. têm o - e- aberto nas f. rizotônicas (aberras, aferra, berram, cerrem, desaferres, desenterre, embezerrem, emperres, erro etc.)

228-errir (1) term. o só v. aguerrir conjuga-se nas f. arrizotônicas

229-ersar (9) term. os v. da língua com esta term. têm o -e-aberto nas f. rizotônicas (adverso, conversas, desconversa, dispersam, malverse, reverses, tergiverse, versem etc.)

230-ertar (28) term. os v. da língua com esta term. têm o - $e$-aberto nas f. rizotônicas (acerto, acobertas, alerta, apertam, concerte, desertes, desperte, dissertem etc.)

231-erter (19) term. o v. verter (e seus vários der.) faz a $1^{\mathrm{a}} \mathrm{p}$.s. do pres.ind. verto, com -efechado (donde o pres.subj. verta, com - $e$-fechado); todas as demais f. são regulares

232-ertir (4) term. os v. advertir e divertir fazem na $1^{\mathrm{a}} \mathrm{p}$.s. do pres.ind. -irto (donde o pres.subj. -irta, irtas etc.), regularizando-se nas demais f., que têm - $e$ - aberto quando rizotônicas (-ertes, -erte, - ertem $)^{171}$

233-ervar (13) term. os v. da língua com esta term. têm o -e-aberto nas f. rizotônicas (conservo, acervas, enerva, inervam, observe, preserves, reservem etc.)

234-erver (2) term. os v. ferver e referver são regulares, mas com a alternância vocálica do -efechado na $1^{a}$ p.s. do pres.ind. (donde o pres.subj.) e -e-aberto nas demais f. rizotônicas; inverter conjuga-se como ver, ver ${ }^{172}$

235-ervir (3) term. excluído intervir, que se conjuga como vir (ver), os poucos v. da língua com esta term., servir e seus der., fazem na $1^{\mathrm{a}}$ p.s. do pres.ind. sirvo (donde sirva etc. no pres.subj.), serves etc., regularizando-se (mas o - $e$ - aberto nas f. rizotônicas) ${ }^{173}$

236-erzir (1) term. o v. cerzir troca o -e-por - $i$ - nas f. rizotônicas (cirzo, donde cirza, cirzes, cirze, cirzem)

237-esar (53) term. os v. da língua com esta term. têm o -e-aberto nas f. rizotônicas (aburgueso, achinesas, afrancesa, aportuguesam, aprese, arreveses, empavese, lesem etc.)

238-escar (7) term. os poucos v. da língua com esta term. têm o -e-aberto nas f. rizotônicas, com mudança do -c-em -qu- antes de -e-desinencial (arabesco, copidescas, despesca, pescam, refresque, pesques, arabesque etc.)

239-escer (67) term. de verbos da $2^{\text {a }}$ conj. provenientes, como cultismos, de v.lat. em -sco,-scis, -scěre (p.ex., floresco, scis, scěre 'florescer', efervesco, scis, scěre 'aquecer-se, aquentar-se, esquentar-se', coalesco, scis, coalüi, coalĭtum, coalescĕre 'crescer com, medrar, aumentar, avultar' etc.); tais cultismos começam a aparecer no sXIV, não raro sob a f. de -ecer (ver), mas é a partir do sXVII em diante que se faz a oposição culta sobre sua grafia, que já pelos fins do sXIX está relativamente regularizada; ver o que se diz a respeito da pronúncia desta term. em -scer

\footnotetext{
${ }^{171}$ Além dos verbos mencionados, há registro de adivertir (com remissão para divertir) e animadivertir ("dar atenção a; atender, cuidar").

${ }^{172} \mathrm{O}$ verbo interver (e não "inverter"), com remissão para entrever, está contabilizado em ver.

${ }^{173}$ Os verbos intervir e desintervir ("encerrar intervenção em empresa, administração pública etc.") estão contabilizados em vir.
} 
240-esclar (2) term. os v. (mesclar e entremesclar) com esta term. têm o -e- aberto nas f. rizotônicas (mesclo, entremesclas, mescle, entremescles etc.)

241-escrer (0) term. o só verbo com esta term. é descrer, que se conjuga como crer, ver ${ }^{174}$

242-esdar (0) term. o só v. da língua com esta term. é der. de dar e se conjuga como este (desdou, desdás, desdá etc. $)^{175}$

243-esgar (6) term. os poucos v. da língua com esta term. têm o -e-aberto nas f. rizotônicas, mudando o - $g$ - para - $g u$ - antes do -e-desinencial (embetesgo, empesgas, enesga, envesgam, embetesgues, empesgue, enesguem pesgue etc.)

244-esler (0) term. o só v. com esta term. é tresler, que se conjuga como ler, ver ${ }^{176}$

245-esmar (7) term. os poucos v. da língua com esta term. têm o -e-aberto nas f. rizotônicas (enresmo, esmas, lesma, quaresmam, resme, sesmes, enresme, lesmem etc.)

246-espar (3) term. os poucos v. da língua com esta term. têm o - $e$-aberto nas f. rizotônicas (encrespo, crespas, desencrespa, encrespem, encrespes etc.)

247-espir (2) term. o v. despir faz na $1^{\mathrm{a}}$ p.s. do pres.ind. dispo (donde todo o pres.subj. dispa etc.), regularizando-se nas demais f., sendo que as rizotônicas têm o -e-aberto; crespir, raro de uso, tende a seguir esse padrão ${ }^{177}$

248-essar (33) term. os v. da língua com esta term. têm o - $e$ - aberto nas f. rizotônicas (apresso, arremessas, arrevessa, atravessam, cesse, confesses, desinteresse, espessem etc.)

249-estar (67) term. os v. da língua com esta term. são regulares, com o - e- aberto nas $\mathrm{f}$. rizotônicas (admoesto, atestas, desinfesta, incestam, manifeste, reflorestes, requeste, testem etc.); mas estar, do lat. sto, as, stěti, stātum, stāre 'estar de pé, estar a servir (à mesa), estar à espera', conjuga-se estou, ás, á, amos, ais, ão; estava etc.; estive etc. (donde estivera etc.; estiver etc.; estivesse etc.); estarei etc.; estaria etc.; estado; estando e assim os dois der. sobestar, sobreestar/sobrestar, que se conjugam igualmente; no culto, porém, registra-se, em épocas várias da língua, instar, distar, eqüidistar, obstar e constar (em que se perdeu a noção de derivação), que se conjugam como v. regulares da $1^{\mathrm{a}}$ conj.

250-estir (10) term. os v. da língua com essa term. fazem a $1^{\mathrm{a}} \mathrm{p}$.s. do pres.ind. -isto (donde todo o pres.subj. -ista etc.), regularizando-se nas demais f., que têm o - $e$ - aberto quando rizotônicas

251-estrar (13) term. os poucos v. da língua com esta term. são regulares, mas com o - e- aberto nas f. rizotônicas (adestro, amestras, fenestra, inadestram, orquestre, palestre, seqüestres, sestrem etc.) $)^{178}$

252-etar (204) term. os v. da língua com esta term. são regulares, mas com o -e- aberto nas f. rizotônicas (afeto, alfabetas, arquiteta, briquetam, colchete, decretem etc.)

253-eter (19) term. com exceção dos v. deter, entreter e reter, que se conjugam como TER (ver), os v. da língua com esta term. são regulares, com a alternação vocálica -e- fechado na $1^{\mathrm{a}} \mathrm{p} . \mathrm{s}$.

\footnotetext{
${ }^{174} \mathrm{O}$ número entre parênteses é zero porque descrer está contabilizado em crer.

${ }^{175} \mathrm{O}$ número entre parênteses é zero porque desdar está contabilizado em dar.

${ }^{176} \mathrm{O}$ número entre parênteses é zero porque tresler está contabilizado em ler.

${ }^{177}$ Crespir é definido como "tornar crespo, áspero, rugoso; encrespar(-se)".

${ }^{178}$ Fenestrar é definido como "fazer abertura, rasgar fenestra ou fenestral em" e sestrar, como "fazer passos de capoeira, de luta corpora".
} 
do pres.ind. -eto (donde o pres.subj. -eta, etas etc. tb. -e-fechado), e -e-aberto nas restantes f. rizotônicas (-etes, -ete, -etem) ${ }^{179}$

254-etir (7) term. os poucos v. da língua com esta term. fazem a $1^{\mathrm{a}} \mathrm{p}$.s. do pres.ind. -ito (donde o pres.subj. com -ita etc.), regularizando-se nas demais f., que têm o - e- aberto quando rizotônicas

255-etrar (13) term. os v. da língua com esta term. são regulares, mas com o -e- aberto nas f. rizotônicas (compenetro, cronometras, impetra, penetram, perpetre, podometres, quilometre, soletrem etc.)

256-eudar (0) term. o v. com esta term., enfeudar, é regular, preservando o ditongo -eufechado $^{180}$

257-eumar (0) term. o v. da língua com esta term., afleumar, é regular, preservando o ditongo fechado $-e$ - $^{181}$

258-eusar (0) term. os v. da língua com esta term. adeusar, desendeusar, endeusar são regulares, preservando em todas as f. o ditongo fechado $-\mathrm{eu}^{-182}$

259-evar (21) term. os v. da língua com esta term. são regulares, mas com o - e- aberto nas f. rizotônicas (abrevo, almocrevas, ceva, desenlevam, eleve, enleves, leve, nevem etc.)

260-ever (16) term. os v. da língua com essa term. distinguem dois grupos: 1) antever, entrever, prever, rever e telever conjugam-se como ver; 2) os demais são regulares, com alternância vocálica no pres.ind. como devo (-e- fechado, donde pres.subj. deva, devas, deva, devam) e deves, deve, devem (-e- aberto), sendo que escrever (e os der. adscrever, circunscrever, descrever, inscrever, manuscrever, prescrever, proscrever, reescrever, sobrescrever, subscrever e transcrever) faz, ademais, o part.pas. em escrito (-scrito $)^{183}$

261-evir (0) term. os poucos v. com esta term. são der. de vir (ver), conjugando-se como este ${ }^{184}$

262-exar (14) term. os poucos v. da língua com esta term. se dividem em dois grupos: 1) o dos em que $0-x$ - vale como/cs/ (anexar, desanexar, indexar, telexar), que são regulares, mas com $\mathrm{o}-\mathrm{e}$ - aberto nas $\mathrm{f}$. rizotônicas (anexo, desanexas, indexem etc.); 2 ) o dos em que o - $x$ - vale $\mathrm{como} / \mathrm{ch} /$ (avexar, desavexar, vexar), que são regulares e mantêm o $-e$ - fechado nas $\mathrm{f}$. rizotônicas ${ }^{185}$

\footnotetext{
${ }^{179} \mathbf{1}^{\circ}$ ) Os verbos deter, entreter e reter estão contabilizados em ter. $\mathbf{2}^{\circ}$ ) Certamente "alternação" aí está no lugar de alternância.

${ }^{180} \mathrm{O}$ número entre parênteses é zero porque enfeudar ("formar feudo em") e desenfeudar ("retirar ou eliminar o feudo de; libertar de jugo") estão contabilizados em -udar.

${ }^{181} \mathrm{O}$ número entre parênteses é zero porque afleumar (“tornar(-se) fleumático, calmo, pachorrento") está contabilizado em -umar.

$182 \mathbf{1}^{\circ}$ ) Diferentemente do que fazem em -izar, aqui os redatores não observam a acentuação gráfica nas formas rizotônicas do radical do presente de reusar. $\mathbf{2}^{\circ}$ ) $\mathrm{O}$ número entre parênteses é zero porque endeusar e outros dois verbos em -usar estão contabilizados em -usar.

${ }^{183}$ Os verbos antever, entrever, prever, rever e telever estão contabilizados em ver.

${ }^{184} \mathrm{O}$ número entre parênteses é zero porque devir, entrevir, revir e sobrevir estão contabilizados em vir.

${ }^{185} \mathbf{1}^{\mathbf{0}}$ ) Além dos verbos mencionados, há registro de complexar, desindexar, multiplexar, reanexar, reindexar, sexar (“determinar o sexo (esp. em aves), por meio de técnicas apropriadas de sexagem"), do grupo 2. $\mathbf{2}^{\circ}$ ) Há registro também de correxar ("soltar a voz (a perdiz)", em cujo verbete não há indicação de pronúncia, assim como ocorre no Volp (1988).
} 
263-exer (2) term. o v. mexer (e derivados) é regular, com alternância vocálica no pres.ind.: mexo (com -e- fechado, donde o pres.subj. mexa, mexas, mexa, mexam) e mexes, mexe, mexem (com -e-aberto) ${ }^{186}$

264-extar (1) term. o só v. da língua com esta term. gráfica é pretextar: a pronúncia do -e- nas f. rizotônicas é controversa, já como aberto, já como fechado; o fato gráfico, porém, não impede que os usuários equiparem este v. aos terminados em -estrar, ver ${ }^{187}$

265-ezar (27) term. os v. com esta term. são regulares, mas com o -e- aberto nas f. rizotônicas (afortalezo, ajaezas, aveza, axadrezam, desenfeze, embelezes, enfeze, enxadrezem etc.)

266-iar (604) term. de v. da $1^{\mathrm{a}}$ conj., contrasta com -ear, e tem número tb. considerável de v., mais de 400 , sendo ainda relativamente fecunda; não apresenta a co-regularidade de -ear, mas seus v., em grande maioria, seguem o padrão, tomado aqui como exemplo, de assobiar: assobio, assobias, assobia, assobiamos, assobiais, assobiam; assobiava etc.; assobiei etc.; assobiarei etc.; assobiaria etc.; assobiasse etc.; assobiar etc.; assobiando; assobiado - o que significa tratar-se de v. regular; há, entretanto, uns quantos - como ansiar e odiar - que cruzam as f. rizotônicas como se fossem em -ear (anseio/odeio, anseias/odeias, anseialodeia, anseiam/odeiam, mas ansiamos/odiamos, ansiais/odiais, donde anseie/odeie, anseies/odeies, anseie/odeie, anseiem/odeiem, mas ansiemos/odiemos, ansieis/odieis) e uns quantos outros como agenciar, alumiar, apreciar, balbuciar, cadenciar, clemenciar, depreciar, desapreciar, desnegociar, despremiar, desremediar, diligenciar, evidenciar, gerenciar, incendiar, indulgenciar, mediar, premiar, presenciar, promediar, remediar, silenciar, vivenciar - que acusam a um tempo o padrão regular de assobiar e o irregular de ansiar, casos em que, pelo menos no Brasil, o padrão de ansiar parece corresponder a uma faixa etária mais velha ou a um registro ruralizante ou popularizante; mobiliar e desmobiliar flutuam, nas f. rizotônicas, entre o acento intensivo em - $b i$ - ou em -li- (apelando-se, no primeiro caso, para grafias como mobilhar, desmobilhar, mobilar e desmobilar, que tornam regulares os v. em causa); em casos de paronímia (do tipo afiar:afear, arriar:arrear, ciar:cear, enfiar:enfear, estiar:estear, piar:pear), ocorre troca de padrões, já no código escrito, já no oral - como forte índice de pequena culturalização formal; ver -oar ${ }^{188}$

\footnotetext{
${ }^{186} \mathrm{O}$ único derivado registrado é remexer.

${ }^{187} \mathbf{1}^{\mathbf{0}}$ ) Certamente a remissão para -estrar aí está no lugar da remissão para -estar. $\mathbf{2}^{\mathbf{0}}$ ) Diante da observação de que "a pronúncia do - $e$ - nas f. rizotônicas é controversa, já como aberto, já como fechado", não fíca claro o que os redatores querem dizer com "o fato gráfico, porém, não impede que os usuários equiparem este v. aos terminados em" -estar.

${ }^{188} \mathbf{1}^{\mathbf{0}}$ ) Note-se que os lexicógrafos registram 604 (e não "mais de 400") verbos em -iar. $\mathbf{2}^{\circ}$ ) Na série de verbos "que acusam a um tempo o padrão regular de assobiar e o irregular de ansiar", devem ser incluídos outros (despreciar, menospreciar e reapreciar, derivados de apreciar; negociar, primitivo do citado desnegociar, e seu outro derivado renegociar, bem como e lumiar e realumiar, respectivamente variante e derivado de alumiar). $\mathbf{3}^{\circ}$ ) Como a observação de que "pelo menos no Brasil, o padrão de ansiar parece corresponder a uma faixa etária mais velha ou a um registro ruralizante ou popularizante" vem modalizada pelo verbo parecer, a informação toma caráter de curiosidade e, por isso, fica desconsiderada para efeito da análise feita neste trabalho. $3^{\mathbf{0}}$ ) Nos casos de paronímia citados, não fica claro o que seria essa "troca de padrões". Considerando-se que haja mesmo uma troca, é difícil imaginar que se diga enfeiou o dedo dentro do ouvido (e não enfiou o dedo dentro do ouvido, como está abonado no verbete enfiar) ou as cores berrantes enfiavam o ambiente (e não as cores berrantes enfeavam o ambiente (como está abonado no verbete enfear). $4^{\circ}$ ) A observação de que "grafias como mobilhar, desmobilhar, mobilar e desmobilar [...] tornam regulares os v. em causa" é contraditória com a afirmação de mobiliar e desmobiliar flutuam, nas f. rizotônicas, entre o acento intensivo em - $b i$ - ou em -li-". $\mathbf{5}^{\circ}$ ) A remissão para -oar é indevida: caberia aqui remissão para -ear (onde há remissão para -iar).
} 
267-ibar (16) term. os v. da língua com esta term. são regulares ${ }^{189}$

268-ibir (7) term. os poucos v. da língua com esta term. são regulares; graficamente, coibir e proibir tomam acento agudo nas f. rizotônicas: -oíbo, -oíbes, -oíbe, -oíbem, -oíba, -oíbas, -oiba, -oibam

269-iblar (1) term. o só v. com esta term., driblar, é regular

270-icar (468) term. os muitos v. da língua com essa term. são regulares, mas trocam o -c- em -qu- antes do -e- desinencial (tipo fabrico, fabrique); tais v. podem ser agrupados nas duas categorias morfológicas segg: 1) v. diretamente provindos do lat. ou formados à sua imagem: abdicar, causticar, claudicar, fabricar, suplicar; 2) v. aspectualmente freqüentativos, iterativos, afetivos, ver in fine de -ico ${ }^{190}$

271-içar (79) term. os v. da língua com esta term. são regulares, mas trocam o -ç- por -c- antes de -e-desinencial (tipo atiço, atice)

272-ichar (31) term. os v. da língua com esta term. são regulares

273-iclar (1) term. os sós v. da língua com esta term. (ciclar e reciclar) são regulares ${ }^{191}$

274-idar (80) term. do lat. -itāre; sua presença em port. ocorre desde as orig. da língua, sendo, porém, muito rara (duvidar, gravidar, intimidar, lapidar, olvidar, ruidar, solidar), ao contrário de seu correspondente -itar (ver), muito prolífico; os v. da língua com esta term. são regulares, mas ruidar, nas f. rizotônicas, tem acento agudo no - $i$ - $(\text { ruido, ruidas etc. })^{192}$

275-idir (12) term. os v. da língua com essa term. são regulares

276-idrar (7) term. os poucos v. da língua com essa term. são regulares

277-ifar (24) term. os v. da língua com essa term. são regulares ${ }^{193}$

278-ifrar (6) term. os poucos v. da língua com essa term. são regulares

279-igar (83) term. os v. da língua com essa term. são regulares, mas trocam o - g- por - gu- antes de -e- desinencial (tipo abriga - abrigue)

280-iger (1) term. o v. viger é tido como defect. na $1^{\text {a }}$ p.s. do pres.ind. (o que acarretaria a ausência do pres.subj., embora ocorra vija etc.); no mais, é regular; o - $g$ - muda-se em - $j$ - antes de - $o$ - ou $-a$ - desinenciais

281-igir (15) term. os v. da língua com essa term. são regulares, com a $1^{a}$ p.s. do pres.ind. -ijo (donde todo o pres.subj. -ija etc.)

282-iglar (1) term. o v. da língua com essa term. (siglar) é regular

283-igmar (2) term. os v. da língua com essa term. são regulares, preservando a seqüência consonântica $-g m^{-194}$

\footnotetext{
189 Aqui está contabilizado ressaibar (“adquirir ressaibo; ressabiar”), para o qual não foi estabelecida terminação.

${ }^{190}$ Em -ico, observa-se "o nexo que há entre o suf. -ico dim. e verbos em -icar, já iterativos, já freqüentativos, já afetivos (pejorativos ou nobilitativos)".

${ }^{191}$ O número entre parênteses é um porque só há registro de ciclar.

${ }^{192}$ Aqui estão contabilizados os verbos em -aidar, -oidar e -uidar, além de peidar, para o qual não foi estabelecida terminação.

${ }^{193}$ Aqui estão contabilizados os verbos em -eifar e -oifar.
} 
284-ignar (8) term. os v. da língua com essa term. são regulares, preservando a seqüência consonântica -gn-

285-igrir (1) term. o v. denigrir (que alterna com denegrir, ver -egrir) é regular

286-iguar (9) term. os poucos v. da língua com essa term. (apaziguar, averiguar, biguar, contiguar, paziguar, santiguar) têm o -u- tônico nas f. rizotônicas: -iguo, -iguas, -igua, -iguamos, -iguais, -iguam; -igúe, -igúes, -igúe, -igüemos, -igüeis, -igúem; ver -aguar, in fine ${ }^{195}$

287-ijar (22) term. os v. da língua com essa term. são regulares ${ }^{196}$

288-ilar (124) term. os v. da língua com essa term. são regulares ${ }^{197}$

289-ilchar (3) term. os v. da língua com essa term. (despilchar, empilchar) são regulares ${ }^{198}$

290-ildar (3) term. os v. da língua com essa term. (humildar, tildar) são regulares ${ }^{199}$

291-ilhar (193) term. os v. da língua com essa term., inclusive ilhar, são regulares; ver -lhar quanto à sua morfologia

292-ilir (1) term. o v. resilir é regular ${ }^{200}$

293-ilmar (4) term. os v. da língua com essa term. (filmar e derivados) são regulares

294-ilrar (2) term. os v. da língua com essa term. são regulares (bilrar, chilrar) ${ }^{201}$

295-iltar (2) term. o v. da língua com essa term. (aviltar) é regular ${ }^{202}$

296-iltrar (2) term. os v. da língua com essa term. (filtrar, infiltrar) são regulares

297-ilvar (2) term. term. o v. da língua com essa term. (silvar) é regular ${ }^{203}$

298-imar (85) term. os v. da língua com essa term. são regulares ${ }^{204}$

299-imbar (13) term. os v. da língua com essa term. são regulares

300-imir (15) term. os v. da língua com essa term. são regulares; exprimir, imprimir, reimprimir têm abundância no part.pas. -presso

301-impar (10) term. os v. da língua com essa term., inclusive impar, são regulares ${ }^{205}$

\footnotetext{
${ }^{194}$ Os verbos são enigmar ("fazer que fique obscuro; tornar enigmático") e estigmar (com remissão para estigmatizar).

195 A remissão para "-aguar, in fine" não se justifica, pois a conjugação descrita lá não coincide com a descrita aqui.

${ }^{196}$ Aqui estão contabilizados os verbos em -eijar.

${ }^{197}$ Aqui estão contabilizados os verbos em -ailar e -oilar.

${ }^{198}$ Despilchar é definido como "despojar (alguém) ou desfalcar-se das pilchas (adornos, jóias, dinheiro, pertences de arreios etc.)" e empilchar, como “enfeitar(-se) com pilchas; adereçar(-se), adornar(-se)”).

${ }^{199}$ Humildar é definido como "tornar(-se) ou mostrar(-se) humilde; humilhar(-se)") e tildar, como"pôr til (sinal diacrítico) em".

${ }^{200}$ Risilir é definido como "pôr fím a uma convenção, a um contrato, a um ato; rescindir, anular".

${ }^{201}$ Bilrar é definido como "trabalhar com bilros ("peça'); produzir renda com bilros" e, em chilrar, há remissão para chilrear ("emitir chilros (os pássaros); chalrear, chilrar").

${ }^{202} \mathrm{O}$ segundo verbo é a variante viltar.

${ }^{203} \mathrm{O}$ segundo verbo é ensilvar ("cercar ou cobrir de silvas ou formar silva (arbusto espinhoso)").

${ }^{204}$ Aqui estão contabilizados os verbos em -aimar, -eimar e -oimar.

${ }^{205}$ Impar é definido como "respirar mal; abafar, ofegar".
} 
302-implir (2) term. os v. adimplir e inadimplir, pouco us. na $1^{\mathrm{a}} \mathrm{p} . \mathrm{s}$. do pres.ind. e, decorrentemente, no pres.subj., são regulares ${ }^{206}$

303-inar (319) term. os muitos v. da língua com essa term. são regulares; arruinar e ruinar têm o $-i$ - graficamente acentuado nas f. rizotônicas: arruíno, ruíno, arruíne, ruíne etc. ${ }^{207}$

304-incar (21) term. os v. da língua com essa term. são regulares, mas o - $c$ - muda em - qu- antes de -e desinencial (tipo brinco - brinque)

305-inçar (9) term. os poucos v. da língua com essa term. são regulares, mas o -ç- muda em -cantes de -e desinencial (tipo pinço - pince)

306-inchar (21) term. os v. da língua com essa term., inclusive inchar, são regulares

307-indar (7) term. os v. da língua com essa term. são regulares

308-indir (6) term. os poucos v. da língua com essa term. são regulares

309-indrar (4) term. os poucos v. da língua com essa term. são regulares (cilindrar, desmelindrar, melindrar $)^{208}$

310-infar (4) term. os poucos v. da língua com essa term. são regulares (grinfar, paraninfar, trinfar) ${ }^{209}$

311-inflar (2) term. o v. inflar e derivados são regulares ${ }^{210}$

312-ingar (29) term. os v. da língua com essa term. são regulares, mas o -g-muda em - gu- antes de -e desinencial (tipo pingo - pingue)

313-ingir (21) term. os v. da língua com essa term. são regulares, com a troca de - $g$ - por $-j$-, antes de - $o$ e - $a$ desinenciais, e um segundo part.pas. -into, em tingir, retingir e destingir (este, mais raro, pela paronímia com distinto)

314-ingrar (2) term. os poucos v. da língua com essa term. (singrar, zingrar) são regulares ${ }^{211}$

315-inguar (4) term. os poucos v. da língua com essa term. (aminguar, deslinguar, minguar) são regulares, com as adequações gráficas: -ínguo, -ínguas, -íngua, inguamos etc.; -íngüe, -íngües , -ingüe, -ingüemos etc.; mas ver -aguar, in fine ${ }^{212}$

\footnotetext{
206 Adimplir é definido como "dar cumprimento a (obrigação, negócio etc.); executar" e seu rerivado inadimplir, como "deixar de cumprir (contrato, condição de contrato, prestação) nos termos e prazo convencionados; descumprir".

${ }^{207}$ Aqui estão contabilizados os verbos em -ainar (amainar e outros oito) -einar (reinar e outros oito) e -oinar (amoinar, "pedir esmola" e outros três) e também arruinar e outros dezoito verbos, para os quais não foi estabelecida terminação.

${ }^{208} \mathrm{O}$ quarto verbo é amelindrar.

${ }^{209}$ Grinfar é definido como "soltar a voz (a andorinha ou a calhandra)" e trinfar como "soltar a sua voz (a andorinha); grinfar, trissar".

${ }^{210} \mathrm{O}$ único derivado registrado é desinflar.

${ }^{211}$ Zingrar é definido como "dirigir troça ou gracejo a; dizer motejo, agir com zombaria; escarnecer, motejar, zombar".

${ }^{212}$ A remissão para "-aguar, in fine” não se justifica, pois a conjugação descrita lá não coincide com a descrita aqui.
} 
316-inguir (3) term. os v. distinguir, extinguir e restinguir são regulares, trocando, pois, o -gupor - $g$ - antes de - o e - $a$ desinenciais (distingo e, assim, distinga etc.), não obstante ocorrências de hiperurbanismo com a pronúncia do $-u-{ }^{213}$

317-inhar (156) term. de v. da $1^{\mathrm{a}}$ conj., conexos em geral com nomes em -inha ou -inho: 1) já numa mera relação mórfica, pois -inha ou -inho, em tais casos, não têm valor sufixal nem conotação própria [...] 2) já numa relação morfossemântica em que -inha/-inho é dim. ou se contamina dessa conotação, levando ao v. certa aura dim., pejorativa ou cariciosa e, por vezes, aspecto freqüentativo[...] 3) os v. da língua com essa term. são regulares: [...] preservam, sobretudo nas f. rizotônicas, os hiatos $a-i$ e $o-i$

318-inir (12) term. os v. da língua com essa term. são regulares

319-inquar (2) term. os v. da língua com essa term. (alonginquar, apropinquar) são regulares, com as adequações gráficas: -ínquo, -ínquas, -ínqua, -inquamos etc.; -ínqüe, -ínqües, -ínqüe, -inqüemos etc.; mas ver -aguar, in fine ${ }^{214}$

320-instar (1) term. o v. instar, o só que é a sua própria term, é regular (como seus der. potenciais desinstar, pré-instar, reinstar etc.)

321-intrar (3) term. o v. pelintrar, que é o único com essa term., é regular ${ }^{215}$

322-inzar (4) term. os poucos v. da língua com essa term. são regulares: acinzar, cinzar, encinzar, ranzinzar

323-ipar (44) term. os v. da língua com essa term. são regulares ${ }^{216}$

324-ipsar (3) term. os v. eclipsar e deseclipsar são regulares, preservando o grupo consonântico impróprio inalterado

325-iquar (3) term. os poucos v. da língua com essa term. (antiquar, coliquar, obliquar) são tidos como conjugáveis nas f. arrizotônicas; há ocorrências de rizotônicas com vacilação na tônica: antiquo ou antíquo, antiquas ou antíquas etc.; mas ver -aguar, in fine ${ }^{217}$

326-ir (756) term. 1) no inf. de todos os v. da $3^{\mathrm{a}}$ conj. (cerca de 639), term. composta da vogal temática $-i$ - da $3^{\mathrm{a}}$ conj. + a desin. $-r$ do inf.pes.; 2) há nela os segg. v. monossilábicos no inf.: ir, rir, vir $[\ldots]$; ver -or ${ }^{218}$

327-irar (223) term. todos os v. da língua com essa term. são regulares ${ }^{219}$

\footnotetext{
${ }^{213}$ Restinguir é definido como "tornar a extinguir".

214 A remissão para "-aguar, in fine" não se justifica, pois a conjugação descrita lá não coincide com a descrita aqui.

${ }^{215}$ Além de pelintrar ("tornar(-se) pelintra", sendo pelintra "que ou aquele que é pobre e mal-ajambrado mas pretende fazer boa figura"), há registro de apelintrar ("tornar(-se) pelintra") e descintrar (com remissão para descimbrar, "retirar os cimbres de (uma abóboda, um arco etc.) após o término de sua construção").

${ }^{216}$ Aqui estão contabilizados os verbos em -aipar (naipar, "jogar cartas do mesmo naipe”, e outros quatro).

${ }^{217}$ A remissão para "-aguar, in fine" não se justifica, pois a conjugação descrita lá não coincide com a descrita aqui.

${ }^{218} \mathbf{1}^{\mathbf{0}}$ ) O número entre parênteses é zero porque os 756 verbos (e não “cerca de 639”) estão contabilizados nas terminações correspondentes a verbos da terceira conjugação. $\mathbf{2}^{\mathbf{0}}$ ) A remissão para -or (registrado como sufixo nominal) é indevida. Caberia em -er caso naquela terminação houvesse menção aos derivados de pôr. Ainda assim, em -or, trata-se apenas dos valores do sufixo nominal ("do lat. -ōris, $e$ ").

219 Aqui estão contabilizados os verbos em -airar (pairar e outros seis), -eirar (beirar e outros 159) e -oirar (aloirar e outros 22).
} 
328-irir (6) term. os v. da língua com essa term. são regulares

329-irmar (8) term. o v. firmar e seus der. são regulares

330-irpar (1) term. o só v. da língua com essa term., extirpar, é regular

331-irrar (6) term. os v. da língua com essa term. são regulares ${ }^{220}$

332-isar (69) term. os v. da língua com essa term. são regulares ${ }^{221}$

333-iscar (50) term. os v. da língua com essa term. são regulares, mas trocam o - $c$ - por - qu- antes de -e desinencial (tipo mordiscas-mordisques); faiscar toma, ademais, acento gráfico no $i$ nas f. rizotônicas (tipo faíscas-faísques); nos casos em que há patente o suf. -isco dim. + -ar é tb. sensível a noção verb. diminutiva ou afetiva: aceniscar, chuviscar, fariscar, lambiscar, mariscar, mordiscar, namoriscar, neviscar, trociscar, troviscar

334-isgar (5) term. os v. visgar, desvisgar e fisgar são regulares, mas trocam o -g-por - gu- antes de -e desinencial (tipo fisgamos-fisguemos)

335-islar (1) term. o v. legislar, o só com essa term., é regular

336-ismar (10) term. os v. da língua com essa term. são regulares

337-isnar (2) term. o v. tisnar e seus der. potenciais (destisnar, retisnar etc.) são regulares ${ }^{222}$

338-ispar (8) term. os poucos v. da língua com essa term. (bispar, chispar, crispar) são regulares 223

339-issar (12) term. os v. da língua com essa term. são regulares: alunissar, amerissar, aterrissar, encomissar, enremissar, inspissar, missar, plissar, trissar; os três primeiros se inspiram em aterrissar, gal. afeiçoado segundo o padrão do fr. atterrissage 'aterrissagem, ação de entrar em contato com o solo' (em aeronáutica e astronáutica), doc. desde 1922 em fr. e, em port., ainda na década de 1920; em Rebelo Gonçalves (1966), reflete-se bem a resistência purista erguida contra o v.: registra ele ${ }^{1}$ aterrar 'causar terror', 'aterrar 'cobrir com terra' e ${ }^{3}$ aterrar 'pousar (o avião) em terra', a que acrescenta "Forma que pretere aterrissar (gal.)", a que junta ainda aterro (ê) em conexão com os três sentidos verbais; o fato é que, enjeitado, o v. (e seus cog.) vem prevalecendo e dando, como se viu, o padrão aeronáutico e astronáutico [...]

340-istar (35) term. todos os v. da língua com essa term. são regulares

341-istir (15) term. os v. da língua com essa term. são regulares

342-istrar (12) term. os v. da língua com essa term. são regulares

343-itar (283) term. pospositivo, do lat. -itāre, f. iterativa de v. da $1^{\mathrm{a}}$ conj. lat. formados de v. de outras conj.; sua presença em port. ocorre desde as orig. da língua, não acusando, porém, a não ser em casos raros, a evolução para -idar (ver), foneticamente esperável; tais v. podem ser grupados nas cinco categorias morfológicas segg.: 1) eruditismos diretamente provindos do lat. ou formados à sua imagem [...], alguns dos quais são, de fato, freqüentativos; 2)

\footnotetext{
${ }^{220}$ Aqui está contabilizado o verbo em -airrar (abairrar).

${ }^{221}$ Aqui estão contabilizados os verbos em -oisar (coisar, "palavra-ônibus us. para suprir um verbo que, por lapso ou ignorância, não ocorre a quem fala; são inúmeros os seus significados", e outros cinco).

${ }^{222}$ Além do verbo tisnar ("tornar(-se) negro; enegrecer(-se) com carvão, fumo etc."), há registro apenas destisnar ("retirar tisna ou mancha(s) escura(s) de; clarear, desenegrecer"), não havendo registro de retisnar.

${ }^{223}$ Bispar é definido como "desempenhar as funções de bispo".
} 
eruditismos de estrutura freqüentativa, conexos, por conseguinte, com os anteriores (em que o suf. -it- é freqüentativo) [...] 3) eruditismos formados de supn. e/ou part.pas. em -t- ou -(c)t[...] 4) eruditismos de base adj., mas através de radicais subst. em -ĭtas,átis (padrão felix:felicitas:felicitáre) [...] 5) em eruditismos de rad. terminados em -t-, ou populismos em dim. em -ito/-ita integrados na $1^{\text {a }}$ conj. (-ar) [...] (análise mais detida permite que alguns exemplos das séries citadas possam aparecer em mais de uma); os muitos v. da língua com essa term. são (em sentido próprio ou figurado) regulares; ajesuitar, porém, traz acento gráfico nas f. rizotônicas (ajesuito, ajesuitas, ajesuíta, ajesuítam; ajesuíte, ajesuítes, ajesuite, ajesuítem $)^{224}$

344-itir (17) term. os v. da língua com essa term. são regulares

345-itmar (1) term. o verbo ritmar e seus der. potenciais (arritmar, desritmar, disritmar) são regulares, preservando a seqüência consonântica inalterada (ritmo, ritmas, ritma, ritmamos etc. e não rítmo, rítmas, rítma ou rítimo, rítimas etc. e menos ainda ritimo, ritimas etc.) $)^{225}$

346-itrar (10) term. os poucos v. com essa term. são regulares

347-itrir (1) term. o v. nitrir é, metaforicamente, regular ${ }^{226}$

348-ivar (82) term. os v. da língua com essa term. são regulares ${ }^{227}$

349-iver (6) term. os v. da língua com essa term. são regulares

350-ivrar (2) term. os poucos v. da língua com essa term. (livrar, deslivrar e seus der. potenciais) são regulares

351-ixar (50) term. todos os v. da língua com essa term. gráfica são regulares, quer o $x$ valha /cs/ (afixar, aprefixar, crucifixar, desafixar, enfixar, prefixar, sufixar, transfixar), quer valha como /ch/ (lixar, maxixar, mixar, rixar); no primeiro caso há, neológico, o v. mixar tb., como 'mesclar' 228

352-izar (1130) term. de v. da $1^{\mathrm{a}}$ conj., com caráter freqüentativo (agonizar, arborizar, fiscalizar etc.) ou causativo (civilizar, humanizar, realizar, suavizar etc.); os muitos v. da língua com essa term. são regulares; quando essa term. é precedida de vogal (ajuizar, arcaizar, desajuizar, desenraizar, desjuizar, desraizar, emboizar, enraizar, europeizar, hebraizar, judaizar, plebeizar), o $i$ se faz graficamente acentuado nas f. rizôtonicas (-aízo, -eízo, -uízo, -aize, -eize, -uize etc. $)^{229}$

\footnotetext{
${ }^{224}$ Aqui estão contabilizados os verbos em -aitar (entupigaitar e outros cinco), -eitar (deitar e outros 49), -oitar (abiscoitar e outros 23) e -uitar (circuitar e outros quatro verbos, além de ajesuitar).

${ }^{225}$ Desnecessário (e contraproducente para a fixação das formas adequadas) conjugar formas verbais não previstas pelas normas de acentuação (rítmo, rítmas, rítma ou rítimo) ou formas de uma suposta variante ritimar, não-registrada neste dicionário. Menos ainda qualquer uma dessas formas verbais com deslocamento impróprio de acento (rítmo, rítmas, rítma ou rítimo).

${ }^{226}$ Nitrir é definido como "emitir nitridos ou relinchos (o eqüídeo); relinchar, rinchar, trinir"

${ }^{227}$ Aqui estão contabilizados os verbos em -aivar (saraivar e outros oito) -eivar (enseivar e outros ) e -oivar (noivar e outros dois), e também uivar, para o qual não foi estabelecida terminação.

${ }^{228}$ Aqui estão contabilizados os verbos em -aixar (abaixar e outros nove), -eixar (deixar e outros vinte) e -oixar (afroixar, com remissão para afrouxar, e outros dois).

229 Aqui estão contabilizados os verbos em -eizar (homogeneizar e outros quatro) e -orizar (horrorizar e outros 73).
} 
353-izer (13) term. o v. dizer (e seus der.) faz a $1^{\text {a }}$ p.s. do pres.ind. digo (donde o pres.subj. diga etc.), dizes, diz etc.; o perf. disse etc. (donde dissera etc., dissesse etc., disser etc.); o imp. dize ou diz, diga, dizei, e o part. dito

354-Ihar (0) term. que engloba grande parte dos verbos em -alhar, -elhar, -ilhar, -olhar e -ulhar; quando conexos com o el. -lha, ver, preservam a noção de dim. (ou, polarmente, aum.), com expressividade fonética de contraste e com conotação pej. por vezes, vistas analiticamente em -alha, -alho, -elho, -ilha, -ilho e -ulho; o caráter sufixal dessa term. - -lhar, em verdade, pode ter um suf. -lh(a/o), de -cula-/-culu-, + o - $a$ - da vogal temática da $1^{\mathrm{a}}$ conj., + o - $r$ desinencial do infinitivo - é mais ou menos vivo conforme o usuário da língua tenha mais ou menos consciência, na sincronia, da diacronia de cada pal. em causa; nas listagens segg., ressalta-se com (v) cada pal. em que parece ser viva a consciência sufixal, caracterizada pela presença física do rad. de base como autônomo do suf. -lhar: 1) abandalhar, abrutalhar (v.) [...]; 2) aconselhar [...], assemelhar (v) [...]; 3) abarbilhar (v.) [...]; 4) abrolhar, aferrolhar (v) [...] 5) aborbulhar (v) $[\ldots]^{230}$

355-oar (261) term. de v. da $1^{\text {a }}$ conj., que devem ser contrastados com os de term. -uar (ver); são cerca de 220 v., regulares; no informal, porém, ocorrem confusões de paradigma, como em abotoar, avoar etc. - que têm a $1^{a}$ p.s. do pres.ind. abotôo, avôo etc.; o ensino busca evitá-lo, estremando as f. próximas, como acoar: acuar, assoar: assuar, soar: suar ${ }^{231}$

356-obar (19) term. os poucos v. da língua com esta term. são regulares, mas têm o -o- aberto nas f. rizotônicas (abobo, adobas, afoba, alfarrobam, arrobe, conglobes, dobe, improbem)

357-obrar (15) term. os poucos v. da língua com esta term., inclusive obrar, têm a vogal -oaberta nas f. rizotônicas (cobro, desdobras, dessoçobra, dobram, exprobre, manobres, obre, recobrem)

358-obrir (6) term. o v. cobrir e seus der. fazem a $1^{\mathrm{a}}$ p.s. do pres.ind. -ubro (donde todo o pres.subj. -ubra etc.), regularizando-se nas demais f., que, se rizotônicas, têm o -o- aberto; o part., porém, é em -oberto (com -e-aberto)

359-obstar (1) term. o só v. com esta term. é o próprio v. obstar (com seus der. virtuais ou potenciais), que é regular (preservando a seqüência consonântica -bs-)

360-obter (0) term. com esta term. só há na língua o v. obter, que se conjuga como ter, ver ${ }^{232}$

361-obvir (0) term. esta term. é só do v. obvir mesmo, que, raro, se conjuga como vir, ver ${ }^{233}$

362-ocar (112) term. os v. da língua com esta term., inclusive ocar, têm a vogal -o- aberta nas f. rizotônicas e mudam o - c- em -qu- antes de - $e$ - desinencial (aboco, avocas, choca, colocam, desloque, enfoques, fofoque, provoquem)

\footnotetext{
${ }^{230} \mathbf{1}^{\circ}$ ) O número entre parênteses é zero porque os 506 verbos em -lhar estão contabilizados em -alhar, -elhar, -ilhar -olhar e -ulhar. $\mathbf{2}^{\circ}$ ) Em -lha, lê-se: "suf. provindo do lat. -cula- ou -lia-, com a noção de dim. (ou polarmente aum.), com expressividade fonética de contraste e com conotação pej., por vezes; ver -alha, -alho, -elho, -ilha, -ilho, -olho e -ulho".

${ }^{231} \mathbf{1}^{\mathbf{}}$ ) Note-se que os lexicógrafos registram 261 (e não "cerca de 220") verbos em -oar. $\mathbf{2}^{\mathbf{0}}$ ) As formas abotôo e avôo são absolutamente regulares, sem qualquer identidade com o paradigma de -uar. É provável que a "confusão de paradigma" se dê nos verbos em -uar: o "informal" sôo, ao lado de suo, embora não haja nenhuma observação a esse respeito em -uar.

${ }^{232} \mathrm{O}$ número entre parênteses é zero porque obter e reobter estão contabilizados em ter.

${ }^{233} \mathrm{O}$ número entre parênteses é zero porque obvir está contabilizado em vir.
} 
363-oçar (26) term. os v. da língua com esta term. são regulares, com o -o- aberto nas f. rizotônicas e o -ç- mudado em -c-antes de -e-desinencial (adoço, almoças, coça, destroçam, emboce, encaroces, esboce, remocem)

364-ochar (27) term. os v. da língua com esta term. são regulares, com o -o- aberto nas f. rizotônicas (abrocho, acochas, agarrocha, atocham, broche, desabroches, deboche, garrochem)

365-oclar (1) term. o v. da língua com esta term., acaboclar, é regular, com o -o- aberto nas f. rizotônicas (acaboclo, acaboclas, acabocla, acaboclam, acabocle, acabocles, acabocle, acaboclem)

366-odar (24) term. os v. da língua com essa term. são regulares, com o -o- aberto nas f. rizotônicas (abnodo, açodas, acomoda, apodam, chapode, denodes, desacomode, podem)

367-oder (3) term. o v. poder (e der. potenciais como repoder, despoder, trespoder, ultrapoder etc.) faz a $1^{\mathrm{a}} \mathrm{p}$.s. do pres.ind. posso (donde o pres.subj. possa etc.), podes, pode, podem (com -o- aberto); perf. pude, pudeste, pôde (com acento gráfico fechado), pudemos, pudestes, puderam (com -e-desinencial aberto) (donde pudera etc., pudesse etc. e puder com -esempre aberto); as demais f. são regulares ${ }^{234}$

368-odir (4) term. os v. da língua com essa term., embora us. nas $3^{\mathrm{as}}$ p., ocorrem tb. na $2^{\mathrm{a}}$ (com o -o- aberto no pres.ind.), havendo ocorrências de explodo (com -o-fechado) e expludo (donde, decorrentemente, exploda etc. ou expluda etc.)

369-odrir (1) term. o v. apodrir, raro, não se conjuga na $1^{\mathrm{a}} \mathrm{p} . \mathrm{s}$. do pres.ind. (donde não ter pres.subj.); nas f. rizotônicas, o - $O$ - é aberto

370-oer (10) term. de verbos da $2^{\text {a }}$ conj., como condoer, corroer, doer, esmoer, moer, remoer, roer e soer, sem contar com poer, como fóssil de pôr; o modelo de moer serve, em princípio, de paradigma: môo, móis, mói, moemos, moeis, moem; moía etc.; moí, moeste, moeu, moemos, moestes, moeram; moerei etc.; moeria etc.; moa, moas, moa, moamos, moais, moam; moesse etc.; moer etc.; moendo; moído; soer vem sendo considerado defectivo na $1^{\mathrm{a}}$ p.s. do pres.ind. e, decorrentemente, no pres.subj. ${ }^{235}$

371-ofar (14) term. os v. da língua com essa term. são regulares, mas com o -o- aberto nas f. rizotônicas (abalofo, afofas, apostrofa, esbofam, estofe, filosofes, fofe, mofem)

372-ofrar (8) term. os poucos v. da língua com essa term. são regulares, mas com o -o- aberto nas f. rizotônicas (alcachofro, aljofras, chofra, desenxofram, encofre, enxofres, gofre, alcachofrem)

373-ofrer (2) o v. sofrer é regular, sendo sofro com -o- fechado (e assim o pres.subj. sofra, sofras, sofram) e as restantes f. rizotônicas com - $O$ - aberto ${ }^{236}$

\footnotetext{
${ }^{234}$ Além do verbo mencionado, há registro de eroder e foder, que diferentemente de poder (e derivados) apresentam apenas alternância vocálica nas formas rizotônicas do radical do presente.

${ }^{235}$ Assim está registrado o "verbo fóssil": poer $v$. (sXIII cf. FichIVPM) ant. t.d. m.q. pôr $\circ$ ETIM f.hist. sXIV pooer".

${ }^{236}$ Além de sofrer, há registro de malsofrer, "suportar com dificuldade".
} 
374-ogar (30) term. os v. da língua com essa term. são regulares, mas com o -o- aberto nas f. rizotônicas e a troca do - $c$ - em - $g u$ - antes do -e-desinencial (ab-rogo, ad-rogas, advoga, afobam, arrogue, bajogues, catalogue, dorroguem $)^{237}$

375-ograr (5) term. os poucos v. da língua com essa term. são regulares, com o -o- aberto nas f. rizotônicas (deslogro, logras, malogra, sogram, deslogre, logres, malogre, sogrem) $)^{238}$

376-oiar (11) term. os poucos v. da língua com essa term. são regulares, mas com o ditongo -oiaberto nas f. rizotônicas: -óio, -óias, -óia, -óiam, -óie, -óies, -óiem; há os que recomendam o -oi- fechado, mesmo nas rizotônicas para aboiar 'acompanhar o trabalho dos bois, embalá-los ao aboio'

377-oiçar (0) term. os poucos v. da língua com essa term. (que em geral alterna com -ouçar) são regulares, mantendo o timbre fechado do ditongo -oi- (ou -ou-) nas f. rizotônicas, mas o -çmuda em -c-antes de -e-desinencial: baloiço, baloice, baloiçamos, baloicemos ${ }^{239}$

378-oidar (0) term. os v. da língua com essa term. (que alterna com -oudar) são regulares, mantendo o timbre fechado do ditongo -oi- (ou -ou-) nas f. rizotônicas ${ }^{240}$

379-oifar (0) term. os v. encoifar e desencoifar e os de igual term. (potenciais) são regulares, mantendo o ditongo - $o i$ - fechado nas f. rizotônicas ${ }^{241}$

380-oilar (0) term. os v. da língua com essa term. (que alterna com -oular) são regulares, mantendo fechado o ditongo -oi- (ou -ou-) nas f. rizotônicas ${ }^{242}$

381-oimar (0) term. o v. coimar e seus der. (acoimar, desacoimar, descoimar, encoimar, escoimar) são regulares, mantendo fechado o ditongo -oi-, que em certas regiões chega a ser nasalizado ${ }^{243}$

382-oinar (0) term. os v. azoinar e estroinar são regulares, mas o timbre do ditongo -oi- nas f. rizotônicas varia de aberto a nasal, segundo as regiões

383-oirar (0) term. os v. da língua com essa term. (que sempre alterna com -ourar) são regulares, mantendo o timbre fechado do ditongo -oi- (ou -ou-) nas f. rizotônicas ${ }^{244}$

384-oisar (0) term. os poucos v. da língua com essa term. (que sempre alterna com -ousar) são regulares, mantendo fechado o timbre do ditongo -oi- (ou -ou-) nas f. rizotônicas ${ }^{245}$

\footnotetext{
${ }^{237}$ Certamente "a troca de -c- em -gu-" aí está no lugar de a troca de -g-em -gu-.

${ }^{238}$ Sograr é definido como "ser sustentado pelo sogro".

${ }^{239} \mathrm{O}$ número entre parênteses é zero porque baloiçar e outros onze verbos em -oiçar estão contabilizados em -içar.

${ }^{240} \mathrm{O}$ número entre parênteses é zero porque adoidar e endoidar estão contabilizados em -idar.

${ }^{241} \mathrm{O}$ número entre parênteses é zero porque encoifar e desencoifar estão contabilizados em -ifar.

${ }^{242} \mathrm{O}$ número entre parênteses é zero porque lantejoilar e outros cinco verbos em -oilar estão contabilizados em -ilar.

${ }^{243} \mathrm{O}$ número entre parênteses é zero porque acoimar (“obrigar a pagar coima; multar”) e outros cinco verbos em -oimar estão contabilizados em -imar.

${ }^{244} \mathrm{O}$ número entre parênteses é zero porque doirar e outros 21 verbos em -oirar estão contabilizados em -irar.

${ }^{245} \mathrm{O}$ número entre parênteses é zero porque coisar ("palavra-ônibus us. para suprir um verbo que, por lapso ou ignorância, não ocorre a quem fala; são inúmeros os seus significados”) e outros cinco verbos em -oisar estão contabilizados em -isar.
} 
385-oitar (0) term. os v. da língua com essa term. (que alterna com -outar) são regulares, mantendo fechado o timbre do ditongo -oi- (ou -ou-) nas f. rizotônicas ${ }^{246}$

386-oivar (0) term. os poucos v. da língua com essa term. são regulares, mantendo fechado o timbre do ditongo -oi- nas f. rizotônicas ${ }^{247}$

387-oixar (0) term. os v. afroixar e entroixar (que alternam com afrouxar e entrouxar) são regulares e mantêm fechado o timbre do ditongo -oi- (ou -ou-) nas f. rizotônicas ${ }^{248}$

388-ojar (22) term. os v. da língua com essa term. são regulares, mas têm o -o- aberto nas f. rizotônicas: alojo, amojas, anoja, bojam, despoje, estojes, poje, rojem

389-olar (122) term. os v. da língua com essa term. são regulares, mas têm o -o- aberto nas f. rizotônicas: abemolo, acebolas, acrisola, assolam, cantarole, degoles, descoles, perolem

390-olcar (5) term. os poucos v. da língua com essa term. são regulares, mas têm o -o- aberto nas f. rizotônicas e o $-c$ - mudado em -qu- antes de -e- desinencial: polco, robolcas, revolca, polque, rebolques, revolquem ${ }^{249}$

391-olçar (2) term. os poucos v. da língua com essa term. são regulares, com o -o- aberto nas f. rizotônicas e o -ç- mudado em -c- antes de -e-desinencial: abolço, abolças, bolça, bolçam, abolces, bolcem ${ }^{250}$

392-oldar (13) term. os v. da língua com essa term. são regulares, com o -o- aberto nas f. rizotônicas: amoldo, contramoldas, desmolda, dessoldam, destolde, moldes, solde, toldem

393-olfar (5) term. os v. da língua com essa term. são regulares, mas com o -o- aberto nas f. rizotônicas: desengolfo, engolfas, golfa, regolfam, solfe, desengolfes, engolfe, golfe, regolfem

394-olgar (12) term. os v. da língua com essa term. são regulares, mas com o -o- aberto nas f. rizotônicas e o -g- mudado em -gu- antes de - e- desinencial: amolgo, colgas, desamolga, desempolgam, empolgue, folgues, refolgue, resfolguem

395-olhar (52) term. os v. da língua dessa term., olhar inclusivamente, são regulares, com o -oaberto nas f. rizotônicas: abrolho, aferrolhas, afolha, bolham, enfolhe, repolhes, restolhe, trambolhem; ver -lhar quanto à sua morfologia

396-olher (11) term. os v. da língua com essa term. são regulares, com a alternância vocálica tipo escolho (com -o- fechado, donde o pres.subj. escolha, escolhas, escolha, escolham) e as restantes f. rizotônicas com -o- aberto (escolhes, escolhe, escolhem)

397-olir (10) term. os poucos v. da língua com essa term. fazem 1) abolir, demolir, emolir, rebolir (não confundir com rebulir 'tornar a bulir') omissão da $1^{1}$ p.s. do pres.ind. (e, logo, de todo o pres.subj.), regularizando-se nas demais f., mas com as rizotônicas com -o- aberto; 2) engolir e desengolir com mudança do -o- em -u- na $1^{\text {a }}$ p.s. do pres.ind. e todo o pres.subj.,

\footnotetext{
${ }^{246} \mathrm{O}$ número entre parênteses é zero porque pernoitar e outros 23 verbos em -oitar estão contabilizados em -itar.

${ }^{247} \mathrm{O}$ número entre parênteses é zero porque noivar e outros dois verbos em -oivar estão contabilizados em -ivar.

${ }^{248} \mathrm{O}$ número entre parênteses é zero porque afroixar (com remissão para afrouxar) e outros dois verbos em -oixar estão contabilizados em -izar.

${ }^{249}$ Rebolcar é definido como "lançar, fazer rolar como bola; precipitar" e, em revolcar, há remissão para rebolcar.

${ }^{250}$ Bolçar é definido como “expelir em jato pela boca; vomitar”) e, em abolçar, há remissão para abolçar.
} 
regularizando-se nas demais f. e com o -o- aberto nas rizotônicas; 3) polir, despolir e repolir, com mudança do -o- em - $u$ - nas f. rizotônicas e todo o pres.subj. ${ }^{251}$

398-olmar (5) term. os v. da língua dessa term. são regulares, com o -o- aberto nas f. rizotônicas: colmo, descolma, despolmas, empolmam, escolme, colmes, despolme, descolmem

399-olpar (1) term. o v. despolpar (com polpar virtualmente) é regular, com o -o- aberto nas f. rizotônicas: despolpo, despolpas, despolpa, despolpam, despolpe, despolpes, despolpe, despolpem

400-olsar (5) term. os poucos v. da língua com essa term. são regulares, com o -o- aberto nas $\mathrm{f}$. rizotônicas: abolso, bolsas, desembolsa, embolsam, reembolse, abolses, abolse, desembolsem

401-oltar (6) term. os poucos v. da língua com essa term. são regulares, com o -o- aberto nas $\mathrm{f}$. rizotônicas: escolto, revoltas, solta, viravoltam, volte, escoltes, revolte, soltem

402-olvar (2) term. os raros v. da língua com essa term. são regulares, com o -o- aberto nas f. rizotônicas: desensolvo, ensolvas, desensolva, ensolvem, desensolvem ${ }^{252}$

403-olver (15) term. os v. da língua com essa term. são regulares, com a alternativa vocálica tipo revolvo (com o -o- fechado, donde o pres.subj. resolva, dissolvas, envolva, volvam) e as restantes f. rizotônicas com $-o$ - aberto ${ }^{253}$

404-omar (23) term. os v. da língua com essa term. são regulares, mas o -o-, mesmo nas f. rizotônicas, é variável, segundo as regiões e classes, indo de aberto a nasalado

405-ombar (22) term. os v. da língua com essa term. são regulares

406-ombrar (8) term. os v. da língua com essa term. são regulares

407-omer (4) term. o v. comer e seus der. são regulares, com o -o- das f. rizotônicas variando de aberto a nasalado, segundo as regiões; carcomer, embora etimologicamente controverso, é do padrão $0^{254}$

408-ompar (3) term. os poucos v. da língua com essa term. são regulares ${ }^{255}$

409-omper (5) term. o v. romper e seus der. são regulares

410-omprar (2) term. o v. comprar (com seus der.) é regular ${ }^{256}$

411-onar (241) term. todos os v. da língua com essa term. são regulares, mas o -o- das $\mathrm{f}$. rizotônicas varia, segundo as classes e regiões, de -o- aberto a nasalado

412-oncar (8) term. os v. da língua dessa term. são regulares, mudando o -ç- em -c-antes do -edesinencial (tipo destronco, destronque) 257

413-onçar (3) term. os poucos v. da língua com essa term. são regulares, mudando o -ç- em -cantes do -e- desinencial (tipo engonçar, engonce) $)^{258}$

\footnotetext{
${ }^{251}$ Além dos verbos mencionados, há registro de depolir, com remissão para despolir.

${ }^{252}$ Ensolvar é definido como "umedecer pólvora de (arma de fogo), para que não dispare") e desensolvar, como "extrair a pólvora úmida de (canhão); desassolvar".

${ }^{253}$ Certamente, "alternativa"aí está em lugar de alternância.

${ }^{254} \mathrm{O}$ número entre parêntese é dois porque só há registro de comer e descomer.

${ }^{255}$ Um dos verbos é apompar ("tornar (algo) pomposo").

${ }^{256} \mathrm{O}$ único derivado registrado é recomprar.

${ }^{257}$ Certamente o "-ç- em -c-" aí está no lugar de -c- em -qu-.

${ }^{258}$ Engonçar é definido como "prender com engonço(s); pôr dobradiça em").
} 
414-onchar (8) term. os poucos v. da língua com essa term. são regulares

415-ondar (15) term. os v. da língua com essa term. são regulares

416-onder (4) term. os v. com essa term. são regulares

417-ondir (1) term. o v. condir, raro, é de conj. arrizotônica

418-ongar (14) term. os v. dessa term. são regulares, mudando o - $g$ - em - gu- antes de -edesinencial (tipo alongo, alongue)

419-onhar (21) term. de verbos da $1^{\mathrm{a}}$ conj., em baixo número, como aliás o dos nomes conexos em -onha e -onho, havendo mera relação mórfica entre os nomes e os verbos do padrão -o- + -ar: avergonhar, congonhar, desavergonhar, desenfronhar, desvergonhar, empeçonhar, encoronhar, enfronhar, entressonhar, envergonhar, ponhar, sonhar; os v. da língua com essa term. são regulares

420-onir (1) term. o v. monir, raro, não tem a $1^{\text {a }}$ p.s. do pres.ind. e, assim, não tem o pres.subj.; regular nas demais $\mathrm{f}^{259}$

421-onjar (2) term. o v. esponjar (e seus der. potenciais) é regular ${ }^{260}$

422-onrar (2) term. o v. honrar (desonrar, cohonrar) é regular ${ }^{261}$

423-onsar (2) term. os v. com essa term., assonsar e responsar, são regulares ${ }^{262}$

424-onstar (1) term. o v. constar é regular

425-onstrar (1) term. o v. demonstrar é regular

426-ontar (36) term. os v. dessa term. são regulares

427-onter (0) term. o v. conter conjuga-se como ter, $\operatorname{ver}^{263}$

428-ontrar (4) term. os v. dessa term. são regulares

429-onvir (0) term. os v. dessa term., convir, desconvir, reconvir, conjugam-se como vir, ver ${ }^{264}$

430-onzar (4) term. os raros v. dessa term. são regulares ${ }^{265}$

431-opar (24) term. os v. com essa term. são regulares, com o -o- aberto nas f. rizotônicas: atropo, copas, ensopa, envelopam, enxarope, galopes, sincope, topem

432-oplar (2) term. o v. acoplar (e derivados) é regular, com o -o- aberto nas f. rizotônicas (acoplo, acoplas, acopla, acoplam, acople, acoples, acople, acoplem)

433-oprar (5) term. os v. da língua com essa term. são regulares, com o -o- aberto nas f. rizotônicas: alopro, assopras, ressopra, sopram, alopre, assopres, ressopre, soprem

\footnotetext{
${ }^{259}$ Monir é definido como "chamar a depor sobre o assunto de uma monitória", sendo monitória "chamamento a depor sobre si ou outrem feito por autoridade; ordem ou mandado judicial").

${ }^{260} \mathrm{O}$ segundo verbo é lisonjar.

${ }^{261}$ Não há registro de "cohonrar" (nem de co-honrar).

${ }^{262}$ Assonsar é definido como "ficar ou fazer ficar um tanto cansado (o cavalo)" e responsar, como "rezar responsos por; sufragar com responsos", sendo responso "conjunto de palavras pronunciadas ou cantadas nos ofícios da Igreja católica, alternadamente por uma ou mais vozes, de uma parte, e pelo coro, como representante da assistência, de outra parte".

${ }^{263} \mathrm{O}$ número entre parênteses é zero porque conter está contabilizado em ter.

${ }^{264} \mathrm{O}$ número entre parênteses é zero porque convir, desconvir e reconvir estão contabilizados em vir.

${ }^{265}$ Um dos verbos é zonzar (“tornar-se zonzo, tonto; azonzar, entontecer, zonzear".
} 
434-optar (2) term. os v. optar e cooptar são regulares, com o -o-aberto nas f. rizotônicas e preservação da seqüência consonântica -pt-: opto, cooptas, opta, cooptam, opte, cooptes, cooptem

435-orar (165) term. os v. da língua com esta term., orar inclusive, são regulares, com o -oaberto nas f. rizotônicas: aboboro, acaloras, afervora, clangoram, deflore, desvigores, empiore, tutorem

436-orcar (15) term. os poucos v. da língua com esta term. são regulares, com o -o-aberto nas f. rizotônicas e o -c-mudado em -qu- antes de -e-desinencial: alborco, alporcas, alporquem, borca, deborcam, desborque, desenforques, emborque, enforquem, forqueis

437-orçar (7) term. os poucos v. da língua com esta term., orçar inclusive, são regulares, com o -o- aberto nas f. rizotônicas e o -ç- mudado em - $c$ - antes de -e-desinencial: desforço, escorças, esforça, forçam, orce, reforces, desforce, escorcemos, esforceis, forcem

438-orcer (6) term. o v. torcer e seus der. são regulares, com a alternância vocálica do tipo torço, com -o- fechado (donde o pres.subj. torça, torças, torça, torçam) e as demais f. rizotônicas com -o- aberto: torces, torce, torcem; o - $c$ - passa a -ç- antes do -o- e - $a$-desinenciais

439-orchar (1) term. o v. escorchar é regular, com o -o- aberto nas f. rizotônicas (escorcho, escorchas, escorche, escorches etc.)

440-ordar (20) term. os $\mathrm{v}$. da língua dessa term. são regulares, com o -o- aberto nas f. rizotônicas: abordo, acordas, borda, concordam, desborde, engordes, recorde, transbordem

441-order (2) term. o v. morder e der. são regulares, com a alternância vocálica tipo mordo (com -o- fechado, donde o pres.subj. morda, mordas, morda, mordam) e as demais f. rizotônicas $\operatorname{abertas}^{266}$

442-orgar (2) term. os poucos v. da língua com essa term. (morgar e outorgar) são regulares, com o - $o$ - aberto nas f. rizotônicas e a mudança de - $g$ - em - $g u$ - antes de $-e$ - desinencial: morgo, morgues, morguemos; outorgo, outorgas, outorgue, outorguemos etc.

443-orir (10) term. dos v. dessa term.: 1) colorir, descolorir, multicolorir não têm a $1^{\mathrm{a}} \mathrm{p} . \mathrm{s}$. do pres.ind. e, assim, o pres.subj., regularizando-se nas demais f., sendo que as rizotônicas têm o -o- aberto; 2) desfloir, florir, reflorir, despavorir e espavorir são tidos como só conjugáveis nas f. arrizotônicas; note-se, porém, que há para algumas $\mathrm{f}$. alternativas regulares da $1^{\mathrm{a}}$ conj.: desflorar, florar, reflorar ${ }^{267}$

444-orizar (0) term. dos v. terminados em -izar, há não poucos em -orizar, correspondentes à parte final do voc. de base + -izar; assim, os voc. de base podem grupar-se da seguinte maneira: 1) terminados em -or de subst. vulgares ou de cultismos lat.: afervorizar [...] 2) de igual term. em verdade de cp. latinos: exteriorizar [...] 3) em pal. terminadas em -or(ia): alegorizar $[\ldots]$ 4) em pal. terminadas em -or(o/a): fosforizar [...] 5) em pal. terminadas em -or (o/a): meteorizar $[.$.$] 6) numa neologia estrangeira: sanforizar 268$

\footnotetext{
${ }^{266} \mathrm{O}$ único derivado registrado é remorder.

${ }^{267}$ Além dos verbos mencionados, há registro de esbaforir-se, que na tábua é conjugado apenas nas formas arrizotônicas.

${ }^{268} \mathbf{1}^{\mathbf{0}}$ ) O número entre parênteses é zero porque os 74 verbos em -orizar estão contabilizados em -izar. $\mathbf{2}^{\mathbf{0}}$ ) Note-se que, nos itens 4 e 5, se repete a mesma informação ("em pal. terminadas em -or(o/a)"), com dois exemplos (fosforizar e meteorizar).
} 
445-orjar (8) term. os v. da língua com essa term. são regulares, com o -o- aberto nas $\mathrm{f}$. rizotônicas: alforjo, desalforjas, desenforja, escorjam, esgorje, forjes, alforje, desalforjem

446-orlar (1) term. o v. orlar é regular, com o -o- aberto nas f. rizotônicas

447-ormar (19) term. os v. da língua dessa term. são regulares, com o -o- aberto nas $\mathrm{f}$. rizotônicas (conformo, deformas, desconforma, desformam, disforme, enformes, forme, informem $)^{269}$

448-ormir (4) term. só o v. dormir e seus der. (adormir, entredormir, redormir, tresdormir, maldormir) têm a $1^{\text {a }}$ p.s. do pres.ind. durmo (donde todo o pres.subj. durma etc.), regulares as demais f., com o-o- aberto nas rizotônicas restantes ${ }^{270}$

449-ornar (31) term. os v. da língua dessa term. são regulares, com o -o- aberto nas f. rizotônicas (abichorno, abochornas, acorna, adornam, amorne, contornes, desorne, retornem)

450-ornir (3) term. os poucos v. com essa term. - desgornir, fornir, gornir - só têm f. arrizotônicas $^{271}$

451-orpar (2) term. os poucos v. da língua com essa term. são regulares, com o - o- aberto nas f. rizotônicas (desencorpo, encorpes etc.

452-orquir (2) term. os v. extorquir e retorquir não têm a $1^{1} \mathrm{p}$.s. do pres.ind. e, assim, todo o pres.subj., regularizando-se nas demais f., que têm - $O$ - aberto nas restantes rizotônicas

453-orrar (297) term. os v. da língua com esta term. são regulares, com o -o- aberto nas f. rizotônicas (aforro, amadorras, azorra, borram, desforre, forres, jorre, torrem)

454-orrer (20) term. os v. da língua com esta term. são regulares, com a alternância vocálica do tipo recorro (com -o- fechado, donde o pres.subj. socorra, socorras, socorra, socorram) e as demais f. rizotônicas com -o- aberto (socorres, socorre, socorrem)

455-orrir (2) term. o v. sorrir conjuga-se como rir (ver) e aborrir não tem a $1^{\mathrm{a}} \mathrm{p} . \mathrm{s}$. do pres.ind. nem todo o pres.subj., regularizando-se nas demais f., que têm -o- aberto nas restantes rizotônicas ${ }^{272}$

456-orsar (2) term. os v. endorsar, extrorsar e introrsar são regulares, com o -o- aberto nas f. rizotônicas ${ }^{273}$

457-ortar (27) term. os v. da língua com esta term. são regulares, com o -o- aberto nas f. rizotônicas (aborto, aerotransportas, aporta, cabortam, comporte, exportes, reporte, suportem)

\footnotetext{
${ }^{269}$ Além dos verbos mencionados, há registro de onze derivados de formar ou informar.

${ }^{270}$ Não havendo registro de redormir, tresdormir e maldormir esta terminação corresponde apenas a dormir e seus derivados adormir ("provocar o sono em; fazer dormir; adormecer"), desdormir ("deixar de dormir; passar em claro") e entredormir.

${ }^{271}$ Gornir é definido como "passar cabo, amarra etc., por um gorne ou outra abertura semelhante" e desgornir, como "retirar (o cabo) do gorne".

${ }^{272} \mathbf{1}^{\circ}$ ) Os verbos sorrir e ressorrir estão contabilizados em rir. $\mathbf{2}^{\circ}$ ) Além de aborrir, há registro de desaborrir.

${ }^{273}$ Em endorsar, há remissão para adorsar ("tornar(-se) curvo como o lombo; arquear") e introrsar é definido como "tornar(-se) introrso", sendo introrso em morf. bot. "voltado em direção ao eixo", não havendo registro de extrorsar.
} 
458-ortir (2) term. o v. sortir troca o -o- em - u- nas f. rizotônicas (logo, tb., em todo o pres.subj.); o v. enfortir, raro, usa-se nas f. arrizotônicas ${ }^{274}$

459-orvar (7) term. os v. da língua com esta term. são regulares, com o -o- aberto nas f. rizotônicas

460-orver (6) term. o v. sorver e seus der. são regulares, com a alternância vocálica do tipo sorvo (com -o- fechado, donde o pres.subj. sorva, sorvas, sorva, sorvam) e as demais f. rizotônicas com -o- aberto (sorves, sorve, sorvem)

461-osar (32) term. os v. da língua com esta term. são regulares, com o -o- aberto nas f. rizotônicas (apoteoso, desposas, dosa, esclerosam, estenose, gloses, necrose, tosem)

462-oscar (10) term. os v. da língua com esta term. são regulares, com o -o- aberto nas f. rizotônicas e a mudança do - $c$ - em -qu- antes do -e-desinencial: abosco, desenroscas, fosca, roscam, tosque, abosques, abosquemos, enrosquem; moscar (embora modernamente apareçam f. suas como as anteriores) tem suas f. rizotônicas com $u$ : musco, muscas, musca, moscamos, moscais, muscam; musque, musques, musque, mosquemos, mosqueis, musquem

463-oser (4) term. o v. coser e seus der. são regulares, com a alternância vocálica do tipo coso (com -o- fechado, donde o pres.subj. cosa, cosas, cosa, cosam) e as demais f. rizotônicas com o -o- aberto (coses, cose, cosem)

464-osmar (1) term. o v. gosmar é regular e com o -o- aberto nas f. rizotônicas ${ }^{275}$

465-osnar (1) term. o v. rosnar é regular, com o -o- aberto nas f. rizotônicas

466-ossar (19) term. os v. da língua com esta term. são regulares, com o -o- aberto nas f. rizotônicas (acosso, amossas, apossa, brossam, desaposse, desengrosses, emposse, reendossem)

467-ossir (1) term. o só v. com esta term., tossir, muda o -o- em -u- na $1^{\mathrm{a}} \mathrm{p}$.s. do pres.ind. (e, assim, em todo o pres.subj.), regularizando-se nas demais f., que têm o -o- aberto nas restantes rizotônicas

468-ostar (26) term. os v. da língua com esta term. são regulares, com o -o- aberto nas f. rizotônicas (acosto, antegostas, aposta, desencostam, desgoste, impostes, poste, tostem)

469-ostir (1) term. o único v. da língua com essa term. é rostir, só conjugado nas f. arrizotônicas $^{276}$

470-ostrar (5) term. os poucos v. da língua com essa term. são regulares, com o -o- aberto nas f. rizotônicas: amostro, entremostras, mostra, prostram, amostre, entremostres, mostre, prostrem $^{277}$

471-otar (113) term. os vários v. da língua com essa term. são regulares, com o -o- aberto nas f. rizotônicas: abarroto, alvorotas, amarrota, bisbilhotam, cambalhote, desbotes, dote, notem

\footnotetext{
${ }^{274}$ Enfortir é definido como "tornar consistente (tecido), no pisão ('máquina')".

${ }^{275}$ Gosmar é definido como "expelir pela boca (mucosidade, escarro); cuspir muito; escarrar”.

${ }^{276}$ Rostir é definido como "dar pancada(s) no rosto de; esbofetear".

${ }^{277}$ Além dos verbos mencionados, há registro de demostrar (com remissão para demonstrar).
} 
472-oubar (0) term. os v. arroubar e roubar são regulares; há a tendência de igualá-los, nas f. arrizotônicas, aos v. em -obar, com a conseqüente conj. segundo o padrão assim criado, não canônico $^{278}$

473-oucar (0) term. os v. da língua com essa term. são regulares, com a troca do -c- em -quantes do -e- desinencial (tipo apouco, apouques); há a tendência, em alguns deles, de igualálos nas f. arrizotônicas aos v. em -ocar, com a conseqüente conj. segundo o padrão assim criado, não canônico (ademais de criador de ambigüidades: aloucar/alocar, desloucar/deslocar, destoucar/destocar, retoucar/retocar, toucar/tocar) ${ }^{279}$

474-ouçar (0) term. os v. da língua com essa term. são regulares, com a mudança do -ç- em -cantes de -e-desinencial (tipo retouço, retouce) $)^{280}$

475-oudar (0) term. os poucos v. com essa term. são regulares ${ }^{281}$

476-oujar (0) term. os v. ajoujar e bajoujar são regulares ${ }^{282}$

477-oular (0) term. os v. enceroular, lantejoular e lentejoular são regulares ${ }^{283}$

478-oupar (0) term. os poucos v. da língua dessa term. são regulares; há a tendência, em certos casos, de igualá-los aos v. em -opar, com a conseqüente conj. nas f. rizotônicas por esse padrão, não canônico ${ }^{284}$

479-ourar (0) term. os v. da língua com essa term. são regulares; há a tendência de igualá-los, por vezes, aos v. em -orar, com a conseqüente conj. segundo esse padrão, o que não é canônico ${ }^{285}$

480-ousar (0) term. os poucos v. da língua com essa term. são regulares; pousar, desse padrão, não deve ser confundido com posar, do padrão -osar, ver ${ }^{286}$

481-outar (0) term. os v. da língua dessa term. (que alterna com -oitar) são regulares ${ }^{287}$

482-ouvar (2) term. o v. louvar (e derivados) é regular ${ }^{288}$

\footnotetext{
${ }^{278} \mathrm{O}$ número entre parênteses é zero porque aboubar, "ter, passar a ter ou encher-se de boubas", sendo bouba definido como "pequena lesão cutânea; escoriação"; arroubar, "tornar(-se) arrebatado, extasiado; enlevar(se), assombrar(-se)" e roubar estão contabilizados em -ubar.

279 O número entre parênteses é zero porque apoucar e outros dezessete verbos em -oucar estão contabilizados em -ucar.

${ }^{280} \mathrm{O}$ número entre parênteses é zero porque balouçar e outros dez verbos em -ouçar estão contabilizados em -uçar.

${ }^{281} \mathrm{O}$ número entre parênteses é zero porque adoudar e endoudar estão contabilizados em -udar.

${ }^{282} \mathrm{O}$ número entre parênteses é zero ajoujar ("prender com ajoujo (cães, bois etc.)") e outros três verbos em -oujar estão contabilizados em -ujar.

283 O número entre parênteses é zero porque, enceroular e outros quatro verbos em -oular estão contabilizados em -ular.

${ }^{284} \mathrm{O}$ número entre parênteses é zero porque poupar e outros cinco verbos em -oupar estão contabilizados em -upar.

${ }^{285}$ O número entre parênteses é zero porque os dourar e outros 23 verbos em -ourar estão contabilizados em -urar.

${ }^{286} \mathbf{1}^{\mathbf{0}}$ ) O número entre parênteses é zero porque pousar e outros sete verbos em -ousar estão contabilizados em -usar. $2^{\circ}$ ) Não devendo os verbos em -ousar ser confundidos com os em -osar, a remissão é indevida. Em verbetes onde se observa confusão de padrões (-oupar e -ourar), a remissão seria cabível, mas não é feita.

287 O número entre parênteses é zero porque tresnoutar e outros dezenove verbos em -outar estão contabilizados em -utar.
} 
483-ouvir (3) term. o v. ouvir e seus der. desouvir, entreouvir, reouvir fazem na $1^{\mathrm{a}} \mathrm{p}$.s. do pres.ind. ouço (donde pres.subj. todo ouça, ouças etc.), regularizando-se em todas as demais $\mathrm{f}^{289}$

484-ouxar (7) term. os poucos v. dessa term. são regulares, não devendo ser confundidos com os do padrão -oxar ou -ochar, ver

485-ovar (26) term. todos os v. da língua com essa term., ovar inclusive, são regulares, com o -oaberto nas f. rizotônicas: aprovo, comprovas, desova, escovam, inove, oves, reprove, trovem

486-over (13) term. os v. da língua com essa term. são regulares, com a alternância vocálica do tipo demovo (com -o- fechado, donde o pres.subj. demova, demovas, demova, demovam) e as restantes f. rizotônicas com o-o- aberto (demoves, demove, demovem); quanto a prover, ver ver; chover é do padrão, se us. figurada ou personalizadamente ${ }^{290}$

487-ovir (0) term. o só v. com essa term. é provir, der. de vir, ver ${ }^{291}$

488-oxar (9) term. os v. da língua com essa term. gráfica, quer o - $x$ - valha/cs/ (paradoxar, xeroxar), quer valha/ch/ (arroxar, broxar, moxar, muxoxar), são regulares, com o -o- aberto nas f. rizotônicas: -oxo, -oxas, -oxa, -oxam, -oxe, -oxes, -oxe, -oxem (xeroxar alterna com xerocar, do padrão -ocar, ver) ${ }^{292}$

489-ozar (7) term. os poucos v. da língua com essa term. são regulares, com o -o- aberto nas f. rizotônicas (gozo, afolozas, algoza, antegozam, goze, afolozes, algozes, antegozem, gozem); compare algozes /ô/ s.m.pl. e a f. verb. homógrafa acima, com o -o- aberto

490-ozer (5) term. o v. cozer e seus der. são regulares, com o -o-fechado em cozo (donde o pres.subj. coza, cozas, coza, cozam) e aberto nas demais f. rizotônicas (cozes, coze, cozem)

491-uar (99) term. os v. terminados em -uar são regulares (com reserva do que adiante se diz), sendo, assim, acentuados tonicamente no - $u$ - rad. (mas não graficamente) das f. rizotônicas, p.ex. atuo, atuas, atua, atuam; atue, atues, atue, atuem; atua, atue, atuem; há, porém, certa confusão de paradigmas em -oar e -uar, quando a vogal rad. é antecedida de $c$-, $q$ - ou $g$-, do que provêm os seg. quadros: -coar, -cuar, -goar, -quar, -guar; 1) -coar: arrincoar, atacoar, decoar, ecoar, escoar, falcoar, incoar, transcoar; são v. que se grafam com -c- para marcarem o hiato $o-a$ e, decorrentemente, numa conj. regular, que é a de todos do grupo, conjugam-se, p.ex., como escôo, escoas, escoa, escoamos, escoais, escoam; escoava etc.; escoei etc.; escoarei etc.; escoaria etc.; escoe etc.; escoasse etc.; escoar etc.; escoando; escoado; 2) -cuar: evacuar, recuar, acuar: são v. que se grafam com -c- para marcarem o hiato $u$ - $a$ e, decorrentemente, numa conj. regular, que é a de todos do grupo, conjugam-se, p.ex., como recuo, recuas, recua, recuamos, recuais, recuam; recuava etc.; recuei etc.; recuarei etc.; recuaria etc.; recue etc.; recuasse etc.; recuar etc.; recuando; recuado; 3) -goar : apregoar, arregoar, avergoar, desbagoar, esbagoar, magoar, pregoar, regoar: são v. que se grafam com -goar (em contraste com -guar) para marcarem o hiato $o$ - $a$, decorrentemente,

\footnotetext{
${ }^{288} \mathrm{O}$ número entre parênteses é zero porque louvar e deslouvar ("não louvar, não elogiar; depreciar”) estão contabilizados em -uvar.

${ }^{289}$ Os únicos derivados registrados são entreouvir e reouvir.

${ }^{290} \mathrm{O}$ verbo prover está contabilizado em ver.

${ }^{291}$ O número entre parênteses é zero porque provir está contabilizado em vir.

${ }^{292}$ Além dos verbos mencionados, há registro de dois outros em que "o - $x$ - vale /cs/ - afloxar (com remissão para afrouxar) e boxar (com remissão para boxear), - e um em que "o - $x$ - vale /ch/" - também enroxar ("fazer ficar ou ficar roxo; $\operatorname{arroxar}(-\mathrm{se})$, arroxear(-se), $\operatorname{roxar}(-\mathrm{se})$ ").
} 
numa conj. regular, conjugam-se, p.ex., como apregôo, apregoas, apregoa, apregoamos, apregoais, apregoam; apregoava etc.; apregoei etc.; apregoarei etc.; apregoaria etc.; apregoe etc.; apregoasse etc.; apregoar etc.; apregoando; apregoado; 4) -quar: são v. que se grafam com -quar (em contraste com -cuar) para marcarem, latinamente, a ausência do hiato $u$ - $a$ (já que $q u$ é orign. uma consoante gutural surda com prolongamento bilabial). Os v. adequar, antiquar, coliquar, obliquar são conjugáveis nas f. arrizotônicas; em relação a alonginquar e apropinquar, nas f. rizotônicas, o acento tônico é no -i-: alongínquo, alongínquas, alongínqüe; apropínquo, apropínqües, apropínqüe; 5) -guar: são v. que se grafam com -guar (em contraste com -goar) para marcarem a ausência do hiato $u$ - $a$ (já que $g u$ é orign. em lat. uma consoante gutural sonora com prolongamento bilabial). Os v. aguar, desaguar, enxaguar, aminguar, minguar, deslinguar, fraguar, embora haja controvérsia preceptiva quanto à acentuação nas formas rizotônicas, devem ser conjugados como águo, ágües, ágüe; mínguo, mínguas, míngua, minguamos, minguais, minguam; deslínguo, deslíngües, deslíngüe, deslinguamos, deslinguais, deslinguam (alguns gramáticos aceitam padrões como aguo, aguas, agua, aguam; agúe, agúes, agúe, agúem); atreguar e eguar têm o -u- tônico nas f. rizotônicas; para apaniguar, apaziguar, averiguar, biguar, contiguar, santiguar há também controvérsia quanto à vogal que recebe a tonicidade: conjugam-se, p.ex., como apaníguo ou apaniguo, apazígüe ou apazigúe; averígüemou averigúem; ver $-\operatorname{aer}^{293}$

492-ubar (15) term. os poucos v. com esta term. são regulares

493-ubir (1) term. o v. subir (e der. potenciais) muda o - u- em -o-aberto no pres.ind. sobes, sobe, sobem; nas demais f. é regular

494-ublar (6) term. os poucos v. da língua com esta term. são regulares

495-ubrar (3) term. os v. elucubrar e lucubrar são regulare ${ }^{294}$

496-ucar (63) term. os v. da língua com esta term. são regulares, com a troca de -c-por -quantes de -e- desinencial (tipo educas, eduques); quando -ucar é antecedido de vogal, o - $u$ toma acento agudo nas f. rizotônicas: tipo abaiúco, abaiucamos; embaúque, embauquemos ${ }^{295}$

497-uçar (37) term. ocorre em v. da $1^{\text {a }}$ conj. cujo rad. nominal formador termina em -uç-, [...], pode assumir caráter de suf. em palavras como empapuçar e lambuçar (este arcaizado em favor de lambujar e enlambuzar); os v. da língua com esta term. são regulares, com a troca do -ç- por -c- antes de -e-desinencial (tipo aguças, aguces); em esmiuçar, o - $u$ - toma acento agudo nas f. rizotônicas (tipo esmiúço, esmiuçamos; esmiúce, esmiucemos) $)^{296}$

498-uchar (25) term. os v. da língua com esta term. são regulares; em agauchar, gauchar (e engauchar) o -u- toma acento agudo nas f. rizotônicas (tipo agaúcho, agauchamos; gaúchas, gaucharam)

\footnotetext{
${ }^{293} \mathbf{1}^{\mathbf{0}}$ ) Aqui não estão incluídos os verbos em -guar e -quar. $\mathbf{2}^{\mathbf{}}$ ) A “confusão de paradigmas em -oar e -uar, quando a vogal rad. é antecedida de $c$-, $q$ - ou $g$-" não justifica que se façam, no verbete -uar, observações específicas dos verbos em -coar (item 1) ou -goar (item 3). Assim também, os verbos em -cuar (item 2) não merecem descrição especial, pois têm comportamento exatamente igual ao de atuar, conjugado regularmente no início do verbete. Apenas os verbos em -quar (item 4) e em -guar" (item 5) mereceriam ser tratados neste verbete. $\mathbf{3}^{\mathbf{0}}$ ) Certamente a remissão para -aer aí está no lugar da remissão para -oar.

${ }^{294} \mathrm{O}$ terceiro verbo é anubrar (com remissão para nubrar).

295 Aqui estão contabilizados os verbos em -oucar. 2) Embaucar é definido como "iludir com astúcia; enganar; atrair" e abaiucar, como "dar ou tomar aspecto de baiúca, bodega ou tasca".

${ }^{296}$ Aqui estão contabilizados os verbos em -ouçar
} 
499-ucir (2) term. o v. aducir só se conjuga nas f. arrizotônicas ${ }^{297}$

500-ucrar (1) term. o v. lucrar (e der. potenciais) é regular

501-udar (49) term. exceto se se tratar de -audar ou -eudar, os v. em -udar são regulares ${ }^{298}$

502-udir (11) term. os v. aludir, deludir, desiludir, eludir, iludir são regulares; acudir e sacudir, com exceção da $1^{\mathrm{a}}$ p.s., mudam o - $u$ - em -o- aberto nas outras f. rizotônicas do pres.ind. (-odes , -ode, -odem), subsistindo a conj. regular nas demais $\mathrm{f}$.

503-uer (0) term. os v. terminados graficamente em -uer (por conseguinte, da $2^{\mathrm{a}}$ conj.) só ocorrem com a sílaba final -guer e tão-somente nos comp. de erguer (reeguer, semi-erguer, sobreerguer, soerguer), em que o - $u$ - só tem a função de fazer o - $g$ - soar como -gue-; assim, a conj., co-regular dos vários v. citados, segue o paradigma ergo, ergues, ergue, erguemos, ergueis, erguem; erguia etc.; ergui, ergueste, ergueu, erguemos, erguestes, ergueram; erguera etc.; erguerei etc.; ergueria etc.; erga, ergas, erga, ergamos, ergais, ergam; erguesse etc.; erguer etc.; erguendo; erguido 299

504-ufar (16) term. os v. da língua com esta term. são regulares

505-uflar (3) term. os poucos v. da língua com esta term. são regulares

506-ugar (39) term. os v. da língua com esta term. são regulares, com a troca de - $g$ - por -guantes de -e-desinencial (tipo alugo, alugue)

507-ugir (13) term. os v. da língua com esta term. são 1) fugir e seus der. (confugir, refugir, subterfugir, transfugir), que faz na $1^{\mathrm{a}} \mathrm{p}$.s. do pres.ind. fujo (donde todo o pres.subj. fuja etc.), foges, foge, fogem (com -o- aberto), regularizando-se em todas as demais f.; 2) encorrugir, estrugir, mugir, remugir, restrugir, rugir, tugir, que (própria ou figuradamente) são regulares, com a mudança do - $g$ - em - $j$ - antes de - o- ou - $a$ - desinenciais (tipo rujo, ruja)

508-ugnar (6) term. os poucos v. da língua com esta term. são regulares e preservam a seqüência consonântica -gn-: pugno (e não púguino ou puguino) $)^{300}$

509-uiar (0) term. os poucos v. da língua com esta term. (aleluiar, bubuiar, conluiar, gapuiar) são regulares ${ }^{301}$

510-uidar (0) term. os v. cuidar, descuidar, recuidar são regulares; liquidar ou liqüidar são do padrão -idar, ver ${ }^{302}$

\footnotetext{
${ }^{297}$ Além de aducir (“trabalhar, amaciar (metal) a fim de torná-lo dúctil, moldável”), há registro de escucir-se ("esgueirar-se, safar-se").

$298 \mathbf{1}^{\mathbf{0}}$ ) Aqui estão contabilizados os verbos em -audar, -eudar e -oudar. $\mathbf{2}^{\mathbf{}}$ ) Diferentemente do que fazem em -izar, aqui os redatores não observam a acentuação gráfica nas formas rizotônicas do radical do presente de agraudar e ensaudar, de um lado, e de amiudar; desmiudar e esmiudar (ambos com remissão para esmiuçar), e miudar (com remissão para miudear, "narrar com os mínimos detalhes; detalhar, pormenorizar"), de outro. $\mathbf{3}^{\mathbf{0}}$ ) Note-se que enfeudar e desenfeudar não apresentam falta de regularidade que justifique a afirmação de que "exceto se se tratar de [...] -eudar, os v. em -udar são regulares".

${ }^{299}$ O número entre parênteses é zero porque erguer e outros quatro verbos com esta terminação estão contabilizados em -erguer.

${ }^{300}$ Desnecessário (e contraproducente para a fixação das formas adequadas) conjugar formas de uma suposta variante puguinar, não-registrada neste dicionário. Menos ainda qualquer uma dessas formas verbais com deslocamento impróprio de acento (púguino).

${ }^{301} \mathrm{O}$ número entre parênteses é zero porque aleluiar e outros dezoito verbos em -uiar estão contabilizados em -iar.
} 
511-uir (72) term. os v. terminados em -uir, da $3^{\mathrm{a}}$ conj., pertencem a dois grupos: o daqueles em que o -u- é foneticamente pronunciado (como abluir, abnuir, afluir, aluir, anuir, atribuir, bluir, circunfluir, cominuir, concluir, confluir, constituir, construir, contribuir, defluir, derruir, desfruir, desinfluir, desobstruir, despoluir, despossuir, destituir, destruir, difluir, diluir, diminuir, diruir, distribuir, eluir, estatuir, estruir, evoluir, excluir, expluir, fluir, fruir, gruir, imbuir, incluir, influir, instituir, instruir, intuir, minuir, obstruir, ocluir, poluir, possuir, precluir, promiscuir, prostituir, pruir, puir, recluir, reconstituir, reconstruir, redistribuir, refluir, reinstituir, renuir, repossuir, repruir, restituir, retribuir, ruir, substituir, usufruir, zuir), e daqueles em que o - u- não é pronunciado, é mero recurso gráfico, como nos casos tratados em -erguer, -anguir, -anquir, -eguir, -equir, -inguir, -orquir; há três padrões que devem ser considerados na conjugação dos v. em -uir com o -u- pronunciado: 1) o dos v. construir, destruir, reconstruir, que apresentam variações de flexão, em relação ao padrão mais geral a saber: construo, construis/constróis, construi/constrói, construímos, construís, construem/constroem; construía etc.; construí, construíste, construiu, construímos, construístes, construíram; construíra etc.; construirei etc.; construiria etc.; construa etc.; construísse etc.; construir, construíres, construir, construirmos, construirdes, construírem; construindo; construído; note-se que, no Brasil, se usa no pres.ind. das f. -uo, -óis, -ói, -oem (com -o-aberto), enquanto em Portugal a tendência é mantê-los dentro do padrão primeiro, sem estranheza, porém, ao segundo; 2) o dos v. argüir, delinqüir, redargüir, com dois subpadrões (o de argüir e redargüir): arguo, argúis, argúi, argüimos, argüis, argúem; argüi, argüiste, argüiu, argüimos, argüistes, argüiram; argüia etc.; argüira etc.; argüirei etc.; argüiria etc.; argua etc.; argüisse etc.; argüir etc.; argüindo; argüido, e o de delinqüir: delínquo/delinquo, delínqües/delinqúis, delínqüe/delinqúi, delinqüimos, delinqüis, delínqüem/delinqúem; delinqüia etc.; delinqüi, delinqüiste, delinqüiu, delinqüimos, delinqüistes, delinqüiram; delinqüira etc.; delinqüirei etc.; delinqüiria etc.; delínqua/delinqua, delínquas/delinquas, delínqua/delinqua, delinquamos, delinquais, delínquam/delinquam; delinqüisse etc.; delinqüir etc.; delinqüindo; delinqüido; sobre essa dualidade, ver o que é dito in fine de -uar, inteiramente aplicável ao caso de delinqüir; 3) o dos demais v. (como exemplo, influir): influo, influis, influi, influímos, influís, influem; influía etc.; influí, influíste, influiu, influímos, influístes, influíram; influíra etc.; influirei etc.; influiria etc.; influa etc.; influísse etc.; influir etc.; influindo; influído; ver -ear ${ }^{303}$

512-uitar (0) term. os v. puitar e circuitar são conexos com um hiato atual (puíta) e um hiato diacrônico (cir-cu-i-tus), postulando nas f. rizotônicas igual padrão: puíto, puítas, puíta, puitam, puíte, puites, puite, puitem; circuito, circuítas, circuíta, circuitamos, circuitais, circuitam $^{304}$

\footnotetext{
${ }^{302} \mathbf{1}^{\circ}$ ) O número entre parênteses é zero porque cuidar e outros três verbos em -uidar estão contabilizados em -idar. $\mathbf{2}^{\circ}$ ) Liquidar, e também alanguidar ("tornar(-se) lânguido, enlanguescido; abater(-se), enfraquecer(-se), extenuar(-se)"), não poderia ter sido considerado verbo em -uidar, pois o - $u$ - participa do dígrafo -qu- e não tem força de vogal.

${ }^{303} \mathbf{1}^{\mathbf{0}}$ ) Certamente por lapso de revisão é que -erguer está incluído na série de casos "em que o - $u$ - não é pronunciado, é mero recurso gráfico" nos verbos em -uir. $2^{\circ}$ ) O "padrão mais geral" dos verbos "com o - $u$ pronunciado" é, estranhamente, o último a ser descrito (item 3). $3^{\circ}$ ) Não se justifica a remissão para -ear.

${ }^{304} \mathbf{1}^{\circ}$ ) O número entre parênteses é zero porque acuitar, "tornar(-se) aflito; apoquentar(-se), atormentar(-se)" e, em luitar, há remissão para luta, estão contabilizados em -itar. $\mathbf{2}^{\circ}$ ) Tanto circuitar quanto puitar ("estacionar (a canoa) no meio do rio, lançando à agua a puíta com uma pedra amarrada na ponta", sendo puita, "corda de embira us. nas jangadas como amarra") deveriam ter sido descritos em -itar, por serem "conexos com um hiato".
} 
513-ujar (37) term. ocorre em verbos da $1^{\mathrm{a}}$ conj., cujo rad. nominal termina em -uj- ou -ugem $[\ldots]^{305}$

514-ujir (2) term. o v. intrujir é regular ${ }^{306}$

515-ular (173) term. os v. da língua com esta term. são regulares; se a term. é precedida de vogal (salvo enjaular, ver -aular), o -ú- se grafa acentuado nas f. rizotônicas: abaúlo, apaúlas, embaúla, faúlam, abaúle, apaúles, embaúle, faúlem ${ }^{307}$

516-ulcar (4) term. os poucos v. da língua com esta term. são regulares, mudando o - $c$ - em -quantes de -e-desinencial (tipo inculcas, inculques)

517-ulgar (7) term. os v. da língua com esta term. são regulares, mudando o - $g$ - em - $g u$ - antes de -e-desinencial (p.ex., julgas, julgues)

518-ulgir (3) term. os v. fulgir, prefulgir, refulgir são regulares, com troca do -g- por -j- antes de -o- e-a-desinenciais (tipo fuljo e fulja, fuljas, fuljamos, fuljais, fuljam) ) $^{308}$

519-ulhar (57) term. os v. da língua com esta term. são regulares; ver -lhar quanto à sua morfologia ${ }^{309}$

520-ulir (4) term. dos v. da língua com esta term., ebulir só se conjuga nas f. arrizotônicas (sem pres.subj., por conseguinte), enquanto bulir, escapulir e rebulir têm todas as f. regulares, salvo as rizotônicas do pres.ind. (-oles, -ole, -olem, com -o- aberto)

521-ulpar (4) term. o v. culpar (e derivados) é regular

522-ulpir (3) term. os v. esculpir e insculpir (e der. virtuais ou potenciais) são regulares

523-ulsar (8) term. os poucos v. da língua com essa term. são regulares

524-ultar (20) term. os v. da língua com essa term. são regulares

525-umar (63) term. os v. da língua com essa term. são regulares; aziumar e ciumar têm o -ugraficamente acentuado nas f. rizotônicas (aziúmo, ciúmas, aziúma, ciúmam, aziúme, ciúmes, ciúmem $)^{310}$

526-umbar (10) term. os v. da língua com essa term. são regulares

527-umbir (7) term. os v. da língua com essa term. são regulares, própria ou figuradamente

528-umbrar (14) term. os v. da língua com essa term. são regulares, própria ou figuradamente

529-umir (9) term. com exceção dos v. sumir e consumir, cujas f. rizotônicas do pres.ind. fazem -omes, -ome, -omem, os demais v. da língua com essa term. são regulares

530-umprir (2) term. os v. cumprir e descumprir são regulares

\footnotetext{
${ }^{305}$ Aqui estão contabilizados os verbos em -oujar.

306 Os dois verbos são intrujir ("ter compreensão de (algo); compreender, perceber, entrujir, intrujar") e entrujir (com remissão para intrujir).

${ }^{307}$ Aqui estão contabilizados os verbos em -aular e -oular.

${ }^{308}$ Prefulgir é definido como "brilhar intensamente; resplandecer, refulgir".

${ }^{309}$ Diferentemente do que fazem em -izar, aqui os redatores não observam a acentuação gráfica nas formas rizotônicas do radical do presente de faulhar ("lançar em forma de faúlhas", havendo em faúlha remissão para fagulha).

${ }^{310}$ Aqui estão contabilizados o verbo em -eumar. $\mathbf{2}^{\circ}$ ) Aziumar é definido como “tornar-se azedo, ácido".
} 
531-unar (31) term. os v. da língua com essa term. são regulares; unar e reiunar têm -uacentuado nas f. rizotônicas ${ }^{311}$

532-uncar (5) term. os v. com esta term. são regulares, mudando o - c- em -qu- antes de $-e$ desinencial (tipo trunco, trunques)

533-unçar (4) term. os v. da língua com esta term. são regulares, mudando o -ç- em -c-antes de -e-desinencial (tipo abagunço, abagunce)

534-unchar (8) term. os v. da língua com esta term. são regulares

535-undar (31) term. os v. da língua com esta term. são regulares

536-undir (15) term. os v. da língua com esta term. são regulares

537-unfar (4) term. os v. da língua com esta term. são regulares

538-ungar (15) term. os v. da língua com esta term. são regulares, mudando o -g- em -gu- antes de -e- desinencial (tipo comungo, comungues)

539-ungir (13) term. os v. da língua com esta term. são (no sentido próprio ou no figurado) regulares, com a troca de - $g$ - por $-j$ - antes de $-o$ - e $-a$ - desinenciais (tipo unjo, unja etc.)

540-unhar (27) term. de v. da $1^{a}$ conj., conexos em geral com nomes em -unha e -unho, com os quais há mera relação mórfica com o acréscimo de -ar, sem conotação semântica especial [...] os v. da língua com esta term. são regulares

541-unhir (4) term. os poucos v. da língua com esta term. (brunhir, engrunhir, grunhir), se conjugados em sentido figurado, podem ser regulares ${ }^{312}$

542-unir (11) term. os v. da língua com esta term., se conjugados em sentido figurado, são regulares; reunir marca, nas f. rizotônicas, o hiato: reúno, reúnes, reúne, reúnem, reúna, reúnas, reúnam ${ }^{313}$

543-untar (21) term. os v. da língua com esta term., untar inclusive, são regulares

544-unver (0) term. o v. circunver conjuga-se como ver ${ }^{314}$

545-unzar (2) term. os v. grugunzar e vunzar são regulares ${ }^{315}$

546-upar (31) term. os v. da língua com esta term. são regulares ${ }^{316}$

\footnotetext{
$311 \mathbf{1}^{\mathbf{0}}$ ) Não há registro de "unar", mas de aunar (“juntar em um todo; adunar, unir”), que efetivamente "tem -u- acentuado nas f. rizotônicas". $\mathbf{2}^{\mathbf{0}}$ ) Além dele e de reiunar ("cortar a ponta da orelha de (animal), ger. a direita, para indicar que é reiúno"), aqui está contabilizado defaunar ("eliminar a fauna de (ambiente)"), para o qual não foi estabelecida terminação.

$3121^{\circ}$ ) Em brunhir, há remissão para brunir (“dar lustro, fazer brilhar (por alisamento, polimento)"); engrunhir é definido como "fazer (o frio, a doença) ficar encolhido, entanguido; engurujar, engelhar" e grunhir, como "engurunhir" (com remissão para engrunhir); $2^{\circ}$ ) Os redatores afirmam simplesmente que esses verbos "podem ser regulares", mas não explicitam qual seria a irregularidade ou, mais provavelmente, a defectividade. Na tábua, os verbos são conjugados regularmente.

${ }^{313}$ Diferentemente do que fazem em -izar, aqui os redatores não observam a acentuação gráfica nas formas rizotônicas do radical do presente de reunir.

${ }^{314} \mathrm{O}$ número entre parênteses é zero porque circunver está contabilizado em ver.

${ }^{315}$ Grugunzar é definido como "pensar insistentemente (em algo); meditar, refletir, matutar", e vunzar, como "remexer (caixa, mala, gaveta etc.)".

${ }^{316}$ Aqui estão contabilizados os verbos em -oupar.
} 
547-upir (5) term. os poucos v. da língua com esta term. podem ser regulares; entupir e desentupir, porém, mais correntemente, fazem no pres.ind. as f. rizotônicas em -opes, -ope, -opem, com -o- aberto ${ }^{317}$

548-uprar (1) term. o v. estuprar é regular

549-uprir (1) term. o v. suprir é regular

550-urar (183) term. todos os v. da língua com esta term. são regulares

551-urbar (8) term. os poucos v. da língua com esta term. são regulares

552-urcar (4) term. os poucos v. da língua com esta term. são regulares, trocando o - c- por -quantes de -e-desinencial (p.ex. bifurco, bifurque)

553-urçar (2) term. os poucos v. da língua com esta term. são regulares, trocando o -ç- por $-c$ antes de -e-desinencial (p.ex. acamurço, acamurce) ${ }^{318}$

554-urchar (1) term. o v. murchar é regular

555-urdar (3) term. os poucos v. da língua com esta term. são regulares ${ }^{319}$

556-urdir (6) term. os poucos v. da língua com esta term. são regulares

557-urgar (7) term. os poucos v. da língua com esta term. são regulares, trocando o - $g$ - por - $g u$ antes de -e-desinencial (p.ex. purgo, purgues)

558-urgir (7) term. os v. da língua com esta term. são regulares, com mudança do - $g$ - em -jantes de - $o$ - e - $a$ - desinenciais; o verbo surgir, em sentido marítimo, tem um segundo part. surto

559-urir (3) term. os v. da língua com esta term. não se conjugam na $1^{\mathrm{a}}$ p.s. do pres.ind.; são eles adurir, comburir, prurir e reprurir, der. do v.lat. urěre 'queimar' - ver em -ust- (notar que transitam da $3^{\mathrm{a}}$ conj.lat. para a $3^{\mathrm{a}}$ port.), ademais de parturir - do v.lat. parturíre 'estar de parto, estar para parir, parir' 320

560-urlar (1) term. o v. burlar é regular

561-urmar (2) term. os poucos v. com esta term. são regulares ${ }^{321}$

562-urnar (4) term. os poucos v. da língua com esta term. são regulares ${ }^{322}$

563-urnir (3) term. os poucos v. da língua com esta term., se conjugados com sentido figurado, podem ser regulares ${ }^{323}$

317 Além dos verbos mencionados, há registro de engrupir e mançupir ("comer sofregamente, como um glutão"), sendo estes dois últimos, na tábua, conjugados regularmente em todas as formas.

318 Além de acamurçar ("preparar (pele de animal) como se faz com a da camurça"), há registro de encamurçar ("cobrir com camurça (os martelos do piano)").

${ }^{319}$ Um dos verbos é chafurdar.

${ }^{320}$ Em-ust-, observa-se que o "el.comp. interpositivo do v.lat. uro, is, ussi, ustum, urĕre 'queimar (no sentido próprio e no figurado, no físico e no moral)" aparece em cultismos port. do sXVI em diante".

${ }^{321}$ Os verbos são enturmar e esvurmar (“espremer pus de (tumor ou pústula); retirar pus espremendo”).

${ }^{322}$ Um dos verbos é enfurnar.

$323 \mathbf{1}^{\mathbf{0}}$ ) Os verbos são burnir (com remissão para brunir, "dar lustro, fazer brilhar (por alisamento, polimento)"), esburnir ("dar (algo) de má vontade ou por obrigação") e gurnir, ("trabalhar afanosamente"). $\mathbf{2}^{\mathbf{0}}$ ) Os redatores afirmam simplesmente que esses verbos "podem ser regulares", mas não explicitam qual seria a irregularidade ou, mais provavelmente, a defectividade. $\mathrm{Na}$ tábua, os verbos são conjugados regularmente. 
564-urpar (2) term. os poucos v. da língua com esta term. são regulares ${ }^{324}$

565-urrar (30) term. os v. da língua com esta term. são regulares

566-ursar (6) term. os poucos v. da língua com esta term. são regulares

567-urtar (4) term. os poucos v. da língua com esta term. são regulares

568-urtir (3) term. os v. da língua com esta term. são regulares

569-urvar (9) term. os v. da língua com esta term. são regulares

570-urzir (1) term. o v. zurzir é regular

571-usar (33) term. os v. da língua com esta term., usar inclusive, são regulares

572-uscar (14) term. os v. da língua com esta term. são regulares, mudando o -c- em -qu- antes de -e- desinencial (tipo busco, busque)

573-usgar (1) term. o v. rusgar é regular, mudando o - $g$ - em -gu- antes de -e-desinencial (tipo rusgo, rusgue)

574-usmar (1) term. o v. chusmar é regular ${ }^{325}$

575-uspir (2) term. o v. cuspir (e seus der. virtuais ou potenciais) só é irregular nas f. rizotônicas do pres.ind. -ospes, -ospe, -ospem, com -o- aberto ${ }^{326}$

576-ustar (22) term. os v. da língua com esta term. são regulares

577-uster (0) term. o v. suster conjuga-se como ter, ver ${ }^{327}$

578-ustir (2) term. os v. enrustir e rustir são regulares

579-ustrar (12) term. os v. da língua com esta term. são regulares; abalaustrar e balaustrar, porém, têm acento agudo no -u- nas f. rizotônicas ${ }^{328}$

580-utar (84) term. os v. da língua com esta term. são regulares, inclusive $u t a r^{29}$

581-utir (12) term. os v. da língua com esta term. são regulares

582-utrir (4) term. o v. nutrir e seus der. são regulares

583-uvar (9) term. os poucos v. da língua com esta term. são regulares; enviuvar e viuvar têm acento agudo no -u- nas f. rizotônicas ${ }^{330}$

584-uxar (20) term. os v. da língua com esta term. são regulares ${ }^{331}$

\footnotetext{
$\overline{324}$ Os verbos são deturpar e usurpar.

${ }^{325}$ Chusmar é definido como "prover (embarcação) de chusma", sendo chusma "o conjunto de remadores de uma embarcação; churma" na segunda acepção).

${ }^{326}$ Os verbos são cuspir e guspir.

${ }^{327} \mathrm{O}$ número entre parênteses é zero porque suster está contabilizado em ter.

${ }_{328}^{32} \mathbf{1}^{\circ}$ ) Diferentemente do que fazem em -izar, aqui os redatores não observam a acentuação gráfica nas formas rizotônicas do radical do presente de abalaustrar e balaustrar. $\mathbf{2}^{\circ}$ ) Aqui estão contabilizados enclaustrar (e outros três), para os quais não foi estabelecida terminação.

${ }^{329}$ Aqui estão contabilizados os verbos em -autar e -outar.

${ }^{330}$ Aqui estão contabilizados os verbos em -ouvar.

${ }^{331}$ Aqui estão contabilizados os verbos em -ouxar.
} 
585-uzar (232) term. ocorre em verbos da $1^{\mathrm{a}}$ conj. cujo rad. nominal termina em -uz ou mesmo -ugem (ver -ujar) [...], em que o suf. presume um -z-de ligação compatibilizador do hiato potencial

586-uzir (31) term. os vários v. da língua com essa term. são regulares, salvo na $3^{\mathrm{a}}$ p.s. do pres.ind. e no imper.: $-u z$

\subsection{SUfixos Verbais}

1 -ar (0) sufixo num universo de 100 mil palavras, levantam-se cerca de 12 mil com esta term.: 1) cerca de 300 adj [... 2) quase todas correspondentes a verbos da nossa $1^{a}$ conj. - em que há o $a$ temático dessa conj. e o $r$ desinencial do inf. -, que perdura praticamente como a única fecunda $[\ldots]^{332}$

$2-\operatorname{cer}(0)$ sufixo $\rightarrow-$ scer $^{333}$

3 -scer (0) sufixo incoativo [...] 1) não é difícil compreender que a form. em -scer é a culta ante a form. em -cer, vulg. ou mais propriamente semiculta ou semivulgar; 2) que o conceito de v. incoativo, 'que capta a ação verbal iniciante', é tanto mais claro quanto mais óbvia seja a existência de um v. que lhe seja $\operatorname{cog}$., pois a maioria dos v. de ação incluem início e continuidade (e, acaso, fim) da ação (destarte, se disponho na minha competência do v. aquietar, ser-me-á mais fácil captar o sentido de aquiescer, na área dos cultismos, assim como, se disponho de avermelhar, ser-me-á mais perceptível o caráter incoativo de envermelhecer); 3) isto postula a questão de por que, na grafia da língua, se mantêm as duas grafias, questão que em primeira instância se relaciona com a pronúncia do $-s$ final da sílaba [...] 4) incursão semidialetológica, é lícito que, de orig., astuto, aspe(c)to, estado, este, instruir (isto é, $-s$ final de sílaba antes de consoante surda) fosse pronunciado como /s/ mesmo, enquanto em deslavado, esbarrar, esmola (isto é, o $-s$ final da sílaba antes de consoante sonora), já estivesse assimilado à sonoridade da consoante, donde /z/; esse estado de coisas perdurou na língua padrão, inclusive em extensas áreas conexas com a cidade de São Paulo e sua extensão bandeirante; em Portugal, porém, nos inícios do sXIX, quando da transmigração, quase em massa, da corte real e seus áulicos e dependentes (que no conjunto teriam dobrado a população do Rio de Janeiro, mais heterogênea no seu falar), a pronúncia culta port., pelo menos a cortesã, já se havia, quanto a esses dois fonemas, palatalizado, donde $\mathrm{o} / \mathrm{s} />/ \mathrm{x} /$ e o $/ \mathrm{z} />/ \mathrm{j} /$, difusão que foi beneficiada pelo maior centro cultural e mais panbrasileiro até aquele então, infletiva para várias áreas, até mesmo o porto de Santos e a baixada santista (na modernidade, o padrão paulista reage, graças aos meios orais de comunicação de massa); 5) essa evolução, sobretudo no que tange a Portugal, deve ter sido objeto de ensino, intensivo, com repercussões já no $\mathrm{sXX}$, no Brasil: assim, para memorizar a inicial ex- (em exame, exórdio, exausto, exibir, exuberância), a pronúncia preconizada foi /eyz/, de que os nordestinos cultos fazem garbo, enquanto no Sul a ditongação não existe, mas a vogal inicial, variável por posição, tende a ser um /ê/, nos casos em que a inicial vocabular é

\footnotetext{
${ }^{332} \mathbf{1}^{\circ}$ ) O número entre parênteses é zero porque os 13209 verbos (e não "cerca de 12 mil") estão contabilizados nas terminações correspondentes a verbos da primeira conjugação. $\mathbf{2}^{\mathbf{}}$ ) Os verbos poder e haver estão indevidamente mencionados no item $2.3^{\circ}$ ) Diferentemente do que fazem -er e -ir, aqui os redatores não mencionam o verbo monossilábico dar.

${ }^{333} \mathrm{O}$ número entre parênteses é zero porque os verbos em -cer estão contabilizados em -ecer, -encer, -ercer e -orcer.
} 
grafada exç-, o fenômeno no Brasil reduz-se a /ês/ (excedente, exceção etc.), enquanto em Portugal passa para o padrão de $-s c$ - a seguir considerado; 6) esse padrão é uma assimilação progressiva do $-s$ final de sílaba já palatalizado $/ \mathrm{x} /$ ao $-s$ - gráfico seguinte, donde, p.ex. fascínio/faxinyio/ ou /fayxinyo/, que foi objeto de ensino no Brasil, nas primeiras décadas do sXX, tipificado por uma ditongação premonitória da grafia: /nayser/, /creyser/, /deyser/; 7) é de atribuir, assim, à escolaridade port. a diferença perdurante da grafia -scer /xer/ e -cer /ser/, que no Brasil não é senão fato gráfico, com eventual ultracorreção do tipo - $(i)$ scer; ver -sc- ${ }^{334}$

\subsection{VERBOS MONOSSILÁBICOS}

1 crer (2) v. [...] conj. irreg.: a) pres.ind.: creio, crês, crê, cremos, credes, crêem; b) imper.: crê, creia, creiamos, crede, creiam; c) pres.subj.: creia etc.; part.: crido [...] Етाм. lat. credo, is, cred̆̈di, credĭtum, credĕre 'crer, confiar, entregar, recomendar, dar crédito, ter por verdadeiro, ter como certo, julgar', pelo lat.vulg. *credēre > port. arc. creer; ver cred-; f.hist. sXIII creer, sXIII creo, sXIV creyo, sXV crer, sXV creio [...] $]^{335}$

2 dar (3) v. [...] conj. irreg.: a) pres.ind.: dou, dás, dá, damos, dais, dão; b) perf.: dei, deste, deu, demos, destes, deram; mais-que-perf.: dera etc.; c) imper.: dá, dê, demos, dai, dêem; d) pres.subj.: dê, dês, dê, demos, deis, dêem; e) imp.subj.: desse etc. f) fut. subj.: der etc. [...] Eтім. lat. do, das, dĕdi, dātum, dăre 'dar, presentear, causar, conceder, permitir, oferecer, ofertar, apresentar, atirar, lançar; reduzir a um estado qualquer, produzir, falecer, dizer, contar, relatar etc.'; ver $d a(d)$-; f.hist. 1211 dar, sXIII dare [... $]^{336}$

3 ir (1) v. [...] conj. irreg.: 1) pres.ind.: vou, vais, vai, vamos, ides, vão 2) pret.imp.: ia etc. 3) perf.: fui, foste, foi, fomos etc. 4) mais-que-perf.: fora etc. 5) imper.: vai, vá, vamos, ide, vão 6) pres.subj. vá, vás, vá, vamos, vades, vão 7) imp.subj.: fosse etc. 8) fut.subj.: for etc. [...] ETIM. lat. eo, is, īvi ou $\breve{i}$, ìtum, ìre; ressalte-se, contudo, que em port. o étimo deste verbo é bem mais complexo do que se informa, estão na base de sua constituição em port. três radicais verbais que, do ponto de vista do lat., eram absolutamente isolados entre si, v.lat. vado, is, vaděre, v.lat. eo, is, ìre e fui, perfectum de esse; com os dois primeiros rad. conjugam-se as f. do pres.ind., pret.imperf.ind., fut.pres.ind., fut.pret.ind., pres.subj., imper. afirmativo e negativo, inf., gerúndio e part., com a seguinte distribuição: rad. de vadĕre, pres.ind. exceto da $2^{\mathrm{a}}$.p.pl., pres.subj., $2^{\mathrm{a}}$ p.s. imper. afirmativo, imper. negativo todo; rad. de $\overline{\text { ire, }} 2^{\mathrm{a}}$ p.pl. ind.pres., pret.imperf.ind., fut.pres.ind., fut.pret.ind., $2^{\mathrm{a}}$ p.pl. imper. afirmativo, formas nominais, inf., gerúndio e part.; com o rad. $f u$-, de esse, conjugam-se pret.perf.ind., pret.m.-q.-perf.ind., pret.imperf.subj., fut.subj.; ver ${ }^{2} i$-; f.hist. 944 uai, sXIII $\operatorname{ir}[\ldots]^{337}$

\footnotetext{
${ }^{334} \mathrm{O}$ número entre parênteses é zero porque os verbos correspondentes em -scer estão contabilizados em -ascer e -escer.

${ }^{335}$ Aqui estão contabilizados crer e descrer.

${ }^{336}$ Aqui estão contabilizados dar, desdar e redar. $\mathbf{2}^{\mathbf{0}}$ ) Note-se que só estão conjugadas as formas dos radicais do presente e do perfeito, tendo sido omitidas do futuro do presente e do futuro do pretérito do indicativo, também irregulares.

${ }^{337}$ A afirmação de que "o étimo deste verbo é bem mais complexo do que se informa" aplica-se ao registro de CunHa (1986: verbete $i r$ ), em seu dicionário etimológico: "Do lat. ìre", mas soa leviana por induzir o usuário a julgar novidade uma descrição mais do que registrada em outras fontes, como em SAID Ali (1931: 149 e 155): "O verbo defectivo *var ou *vaer (lat. vadere) tem o presente do indicativo vou, vais (port. ant. vás), vamos, vão, faltando a $2^{\mathrm{a}}$ do plural. As tres primeiras formas e as ultimas supprem as formas pessoaes de que ficou privado o verbo ir. Vamos concorre com imos e é linguagem geralmente mais aceita." e "O pret. perf. fui, que em portuguez tanto serve para o verbo ser como para o verbo ir faz fui, foste, foi, fomos, fostes, foram. Em
} 
4 ler (3) v. [...] a respeito da conj. deste verbo, ver gram no verbete crer [...] ETIM lat.cl. lĕgo, is, lègi, lectum, legěre 'recolher, apanhar; enrolar, tirar; escolher, captar com os olhos; ler em voz alta' $[\ldots]^{338}$

5 pôr (41) v. [...] d) conj. irreg.: pres.ind.: ponho, pões, põe, pomos, pondes, põem; pret.imp.: punha etc.; perf.: pus, puseste, pôs, pusemos etc.; mais-que-perf.: pusera etc.; fut.pres.: porei etc.; fut.pret.: poria etc.; imper.: põe, ponha, ponhamos, ponde, ponham; pres.subj.: ponha etc.; imp.subj.: pusesse etc.; fut.subj.: puser etc.; gerúndio: pondo; particípio: posto e) pl. (do subst.): pores [...] EтIM. lat. pono, is, posŭi, positum, poněre 'pôr, colocar, postar; pousar; plantar; fixar, estabelecer, construir, edificar, executar, fazer; expor; atribuir, considerar; empregar; aplicar; apor; propor, oferecer; dispor, ordenar, arranjar; expor; relatar, contar'; ver -por; f.hist. sXIII põ, sXIII pon, sXIII ponnades, sXIII porrei, sXIII pos, 1365 poron, sXIV põe, sXIV poese, sXIV põham, sXIV poia, sXIV poiinham, sXIV poño, sXIV posso, sXIV poussem, sXIV pugj, sXIV puynha, sXV poiria, sXV ponia, sXV ponte, sXV poz [...] $]^{339}$

$6 \operatorname{rer}(1) / \hat{e} / v$. [...] Етім. lat. rado, is, rasi, rasum, radĕre 'raspar, rapar, arranhar', cp. it. radere, fr.ant. rere, provç. raire, cat. raure, esp. raer, port.ant. rer; ver ras-; f.hist. 1899 rêr ${ }^{340}$

7 rir (3) v. [...] Етім. lat. riděo, es, rīsi, rïı́sum, ridēre 'rir, rir-se de; sorrir, gracejar; zombar'; ver rid-; f.hist. sXIII riindo, sXIV riin, sXIV rijr, sXIV rriyr, sXV rir [... $]^{341}$

8 ser (1) v. [...] conj. irreg.: modo indicativo a) pres.: sou, és, é, somos, sois, são; b) pret.imperf.: era, eras, era, éramos, éreis, eram; c) pret.perf.: fui, foste, foi, fomos, fostes, foram; d) pret.m.-q.-perf.: fora (ô), foras (ô), fora (ô), fôramos, fôreis, foram; e) fut.pres.: serei, serás, será, seremos, sereis, serão; f) fut.pret.: seria, serias, seria, seríamos, seríeis, seriam; 3) modo imper.: a) sê, seja, sejamos, sede, sejam; 4) modo subjuntivo a) pres.: seja, sejas etc.; b) imperf.: fosse (ô), fosses (ô), fosse (ô), fôssemos, fôsseis, fossem (ô); c) fut.: for

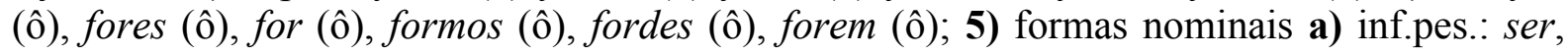
seres, ser, sermos, serdes, serem; b) gerúndio: sendo; c) part.: sido [...] EтाM. lat. seděo, es, sēdi, sessum, sedēre 'estar sentado, assentar-se, ficar sentado', fundido com formas do v.lat. esse 'ser'; da idéia original de 'estar sentado' passou à de 'ser'; ver s(er)-; f.hist. 938 sudes, 1044 seia, 1289 syha, sXIII e, sXIII eran, sXIII fui, sXIII seer, sXV sia, c1543 sees [...] $]^{342}$

$9 \operatorname{ter}(11) v .[\ldots]$ conj. irreg.: 1) pres.ind.: tenho, tens, tem, temos, tendes, têm; 2) imperf.: tinha, tinhas etc.; 3) perf.: tive, tiveste, teve, tivemos, tivestes, tiveram; 4) mais-que-perf.: tivera, tiveras etc. 5) fut.pres.: terei, terás etc.; 6) fut.pret.: teria, terias etc.; 7) imper.: tenha, tem,

port. ant. usou-se foi para a $1^{\mathrm{a}}$ pessoa e fuste para a $2^{\mathrm{a}}[\ldots]^{\prime \prime}$.

${ }_{338} \mathbf{1}^{\mathbf{0}}$ ) Aqui estão contabilizados ler, reler e tresler. $\mathbf{2}^{\mathbf{0}}$ ) Diferentemente do que se verifica no verbete de outros verbos monossilábicos, não o verbo ler não é conjugado, havendo mera remissão para crer.

${ }^{339}$ Aqui estão contabilizados pôr e derivados.

${ }^{340} \mathrm{Na}$ tábua, rer não se conjuga por ser "Forma antiga não conjugável pelos padrões atuais".

${ }^{341} \mathbf{1}^{\mathbf{0}}$ ) Aqui estão contabilizados rir, sorrir e ressorrir. $\mathbf{2}^{\mathbf{0}}$ ) Note-se que não se conjuga o verbo rir, embora haja remissão para este verbete em -orrir: "o v. sorrir conjuga-se como rir (ver)".

${ }^{342}$ Note-se que a formação de ser ("lat. seděo, es, sēdi, sessum, sedère [...] fundido com formas do v.lat. esse") é descrita sem referência à distribuição dos dois radicais latinos nas formas do verbo português, diferentemente do que se faz em ir: "com os dois primeiros rad. [do lat. vado, is, vaděre e do lat. eo, is, ìre] conjugam-se as f. do pres.ind., pret.imperf.ind., fut.pres.ind., fut.pret.ind., pres.subj., imper. afirmativo e negativo, inf., gerúndio e part., com a seguinte distribuição: rad. de vaděre, pres.ind. exceto da $2^{\mathrm{a}}$.p.pl., pres.subj., $2^{a}$ p.s. imper. afirmativo, imper. negativo todo; rad. de ire, $2^{a}$ p.pl. ind.pres., pret.imperf.ind., fut.pres.ind., fut.pret.ind., $2^{\mathrm{a}}$ p.pl. imper. afirmativo, formas nominais, inf., gerúndio e part.; com o rad. fu-, de esse, conjugam-se pret.perf.ind., pret.m.-q.-perf.ind., pret.imperf.subj., fut.subj.”. 
tenha, tenhamos, tende, tenham; 8) imper.neg.: não tenhas, não tenha etc.; 9) pres.subj.: tenha, tenhas etc.; 10) imperf.subj.: tivesse, tivesses etc.; 11) fut.subj.: tiver, tiveres etc.; 12) inf.pes.: ter, teres, ter, termos, terdes, terem [...] Етім. lat. tenĕo, es, üi, tentum, ère 'segurar, agarrar, pegar em, possuir, ter, ser dono, obter, adquirir, granjear etc.'; doc. 1047 teve, sXII teer, 1211 teenr (mera var. gráf. da f. anterior), sXIII teendo, ainda no sXVI teer, quando começa a coexistir com teer, f. esta que tb. já ocorre no sXIII; a partir do sXIV documenta-se tb. ter, que se estabiliza no sXVII; o rad. do perfeito foi teve (teui, tenvi), que cedo acusa a metafonia tive: teve (com generalização regular a partir do sXVI: tivera: tivesse: tiver); a $1^{\mathrm{a}}$ p.s. do pres.ind. tenho, foneticamente regular, é seguramente base de tenha etc.; o part.pas. teúdo, regular arc. (a.sXVI), manteve-se substv. em parte da cognação (teúdo, conteúdo, manteúdo); ver ten-; além das acp. referidas no desenvolvimento deste verbete, o IVPM registrou e datou as seguintes outras, que no nosso texto não figuram por arcaicas na língua: 'aguardar, esperar' (sXIII); 'dar-se bem' (sXIII); 'haver, existir' (sXIV) 343

$10 \operatorname{ver}(10) v .[. .$.$] conj. irreg.: a) pres.ind.: vejo, vês, vê, vemos, vedes, vêem; b) pret.imp.: via$ etc.; c) perf.: vi etc.; d) mais-que-perf.: vira etc.; e) imper.: vê, veja, vejamos, vede, vejam; f) pres.subj.: veja etc.; g) imp.subj.: visse etc.; h) fut.subj.: vir etc.; i) part.: visto [...] Етім. lat. viděo, es, vīdi, vīsum, ère 'ver; olhar, ir ver; perceber; compreender; examinar, considerar; ver com os olhos do espírito'; ver vid-; f.hist. sXIII uēer, sXIII uiren, sXIV bio, sXIV vee, sXIV veer, $\mathrm{sXIV}$ vegote, $\mathrm{sXIV}$ vejo, $\mathrm{sXIV}$ viu, $\mathrm{sXIV}$ vyo ${ }^{344}$

11 vir (15) v. [...] conj. irreg.: 1) pres.ind.: venho, vens, vem, vimos, vindes, vêm 2) pret.imp.: vinha etc.; 3) perf.: vim, vieste, veio, viemos etc. 4) mais-que-perf.: viera etc. 5) imper.: vem, venha, venhamos, vinde, venham 6) pres.subj.: venha etc.; 7) imp.subj. viesse etc. 8) fut.subj. vier etc. 9) gerúndio: vindo 10) part.: vindo [...] ETIM. lat. venĭo, is, vēni, ventum, venīre 'vir, chegar, abordar, abicar, agredir, atacar, avançar, acometer, romper etc.'; ver -vir; f.hist. 1101 uen, sXII viir, sXII vinir, sXIII ueeeren, sXIII uijr, sXIII veer, sXIII venir, 1393 vyr, sXIV virs, sXIV-XV vir, sXV viinr ${ }^{345}$

\subsection{TERMinaÇõES NÃO-ESTABELECIDAS}

Ferindo-se o princípio da uniformização, não foram estabelecidas 103 possíveis terminações, em grande parte correspondentes a verbos de baixa ocorrência: 63 delas corresponderiam a um único verbo (como -ibrar, para vibrar); 21, a dois verbos (como -argüir, para arg e redargüir); quatro, a três verbos (como -auchar, para agauchar, gauchar e encauchar), e quatro, a quatro verbos (como -ispor, para dispor, indispor, predispor e redispor).

\footnotetext{
${ }^{343} \mathbf{1}^{\circ}$ ) Aqui estão contabilizados ter e derivados. $\mathbf{2}^{\circ}$ ) Note-se que conjugam também formas regulares, como as do futuro do presente e do pretérito do indicativo.

${ }^{344} \mathbf{1}^{\mathbf{0}}$ ) Aqui estão contabilizados ver e derivados. $\mathbf{2}^{\mathbf{0}}$ ) Note-se que não se conjugam todas as formas com irregularidade, como as do futuro do pretérito perfeito.

${ }^{345}$ Aqui estão contabilizados vir e derivados.
} 


\subsubsection{TeRminaÇões QUe CORRESPONDERIAM A VERbos QUE SERIAM CLASSIFICADOS SIMPLESMENTE COMO REGULARES}

1 -ablar (1) para cablar ("transmitir (mensagem telegráfica) por cabo submarino")

2 -abrar (3) para cabrar ("levantar o nariz de (aeronave), ou ter (aeronave) seu nariz inclinado para cima, durante o vôo; voar ou fazer voar (a aeronave) dessa maneira", na primeira acepção), descalabrar (com remissão para escalavrar, e endiabrar) e endiabrar

3 -aflar (1) para aflar, ("lançar ou inspirar (o ar) pela boca ou nariz; bafejar, soprar" na primeira acepção)

4 -afrar (2) para açafrar (com remissão para açafroar, "tingir com açafrão") e espinafrar

5 -albar (1) para o dealbar (“tornar branco; clarear” na primeira acepção)

6 -ampir (1) para campir ("fazer a perspectiva do horizonte em (um quadro)")

7 -anfar (2) para afanfar ("atingir com golpes; bater, surrar") e ganfar ("apanhar com destreza; agarrar, segurar" na primeira acepção)

8 -anfrar (1) para chanfrar ("fazer chanfro em; cortar em ângulo ou de esguelha; recortar em forma de meia-lua; biselar" na primeira acepção)

9 -antrar (1) para achantrar ("não declarar")

10 -arsar (1) para esparsar ("fazer ir ou ir para todos os lados; espalhar(-se), difundir(-se), espargir(-se), na primeira acepção)

11 -astir (2) para bastir ("erigir edificação; construir") e embastir (com remissão para embastecer, "tornar(-se) basto, espesso; compactar(-se), embastir(-se)")

12 -eiar (2) para enseiar ("formar seio em", sendo seio "dobra ou prega sinuosa; curvatura, volta, sinuosidade") e veiar ("tornar visíveis veias ou quaisquer vasos sanguíneos de")

13 -embar (5) para verbos como mambembar

14 -emblar (1) para temblar ("pôr acordes (instrumentos), uns com os outros; ajustar, harmonizar")

15 -enrar (1) para atenrar

16 -ibrar (13) para verbos como vibrar

17 -igrar (7) para verbos como migrar

18 -imbrar (4) para cimbrar ("dar forma de cimbre; azumbrar, corcovar" na primeira acepção sendo cimbre "armação provisória, ger. de madeira, que serve de molde e de suporte durante a construção de arcos e abóbadas; címbrio, simples"), descimbrar ("retirar os cimbres de (uma abóboda, um arco etc.) após o término de sua construção; descintrar"), timbrar e zimbrar ("golpear, fustigar com açoite ou similar; dar pancadas em; açoitar, vergastar, zurzir" na primeira acepção)

19 -iplar (1) para atiplar (“dar característica de tiple ('soprano') a (voz, instrumento); afinar, esganiçar")

20 -irtar (1) para hirtar ("tornar-se hirto; eriçar-se") 
21 -isdar (1) para satisdar (“oferecer fiança, dar caução")

22 -udrar (1) para enludrar ("fazer ficar ludro, sujo; turvar")

23 -ufir (1) para bufir (com remissão para bufar)

24 -umbrir (1) para zumbrir-se ("tornar-se curvo; arquear-se, dobrar-se, vergar-se")

25 -usir (1) para ico ilusir (com remissão para iludir).

26 -unstar (1) para circunstar ("estar ao redor" na primeira acepção)

27 -uplar (1) para decuplar (com remissão para decuplicar)

28 -urfar (1) para surfar

\subsubsection{TERMINAÇões QUE CORRESPONDERIAM A VERBOS QUE SERIAM DECLARAdOS REGULARES COM DESCRIÇÃo dA PARTICULARIDAdE}

1 -aibar (1) para ressaibar ("adquirir ressaibo; ressabiar", sendo ressaibo, "mau sabor; ranço"), com preservação do ditongo

2 -aislar (1) para aislar ("isolar (algo ou alguém) em ilha; ilhar, insular"), com preservação do ditongo

3 -apsar (1) para colapsar ("causar ou sofrer um colapso", na primeira acepção), com preservação do encontro consonantal

4 -arctar (2) para arctar ("apertar muito, estreitamente") e coarctar ("reduzir(-se) a limites mais restritos; restringir(-se), estreitar(-se), circunscrever(-se)"), com preservação do encontro consonantal

5 -augir (1) para augir ("atingir o auge de”), com discordância gráfica

6 -aunar (1) para defaunar, com preservação do ditongo

7 -austrar (2) para abalaustrar ("colocar balaústre(s) em; guarnecer com balaústre(s); balaustrar") e balaustrar, com preservação do ditongo

8 -ãzar (1) para anãzar (com remissão para ananicar, "tornar nanico ou anão; impedir que alcance o desenvolvimento natural; anãzar, ananzar" na primeira acepção), com o grafema $\tilde{a}$ atipicamente em sílaba medial ${ }^{346}$

9 -eclar (1) para teclar, com alternância vocálica

10 -eflar (1) para reflar (“atacar com o refle (sabre-baioneta)”), com alternância vocálica

11 -egnar (2) para desimpregnar e impregnar, com preservação do encontro consonantal

12 -egrar (11) para verbos como regrar, com alternância vocálica

13 -eidar (1) para peidar, com preservação do ditongo

\footnotetext{
${ }^{346} \mathrm{O}$ grafema $\tilde{a}$ é usado para indicar a nasalização do /a/ quando a vogal faz parte de ditongos nasais /प̣/ e.// e quando é marca de feminino. Neste último caso, aparece em um reduzidíssimo número de nomes, aos quais se pode acrescentar um sufixo diminutivo sem que haja troca de grafemas (irmã: irmãzinha, fã: fanzinha). No caso do acréscimo de outros sufixos, contudo, usa-se an (fã: fanzine: fanzoca; mão: manzorra, cão: canzarrão).
} 
14 -eldar (1) para beldar (“falar muito sem nada dizer; tagarelar”), com alternância vocálica

15 -elgar (1) para adelgar, com alternância vocálica

16 -elpar (2) para felpar ("recobrir, dotar de felpa(s)") e enfelpar ("forrar com felpa ('tecido')", na primeira acepção), com alternância vocálica

17 -eltar (1) para esbeltar, com alternância vocálica

18 -emptar (1) exemptar, com remissão para isentar, com preservação do encontro consonantal

19 -ilgar (1) para empocilgar, com discordância gráfica

20 -iptar (1) para encriptar, com preservação do encontro consonantal

21 -irgar (2) para desvirgar (com remissão para desvirginar) e sirgar ("atar ou dotar com sirgas", na primeira acepção, sendo sirga "cabo para reboque de navios"), com discordância gráfica

22 -oldrar (1) para espoldrar ("podar pela segunda vez (a videira)”, na primeira acepção), com alternância vocálica

23 -orber (1) para absorber, com alternância vocálica

24 -orfar (2) para morfar ("comer em demasia", na primeira acepção) e amorfar (com remissão para morfar), com alternância vocálica

25 -oslar (1) para broslar (com remissão para bordar), com alternância vocálica

26 -otrar (1) para apotrar-se (“adquirir (o cavalo) birras de potro”, na primeira acepção), com alternância vocálica

27 -uctar (1) para eructar, com preservação do encontro consonantal

28 -udlar (1) para pudlar (“transformar (ferro) em aço, separando o carbono; apurar”), com preservação do encontro consonantal atípico do português

29 -uivar (1) para o verbo único uivar, com preservação do ditongo

\subsubsection{TERMINAÇÕES QUE CORRESPONDERIAM A DERIVAdOS DE VERBOS MONOSSILÁBICOS}

1. -abster (1) para o próprio abster

2. -advir (1) para o próprio advir

3. -anspor (1) para transpor

4. -apor (6) para verbos como o próprio apor

5. -epor (6) para antepor e mais cinco verbos

6. -erpor (2) para interpor e superpor

7. -expor (3) para expor, subexpor e superexpor

8. -impor (3) para impor, desimpor e reimpor

9. -ispor (4) para dispor, indispor, predispor e redispor

10. -obpor (1) para sobpor 
11. -ompor (5) para verbos como compor

12. -opor (5) para verbos como o próprio opor

13. -ospor (1) para pospor

14. -ubpor (1) para subpor

15. -upor (2) para supor e pressupor

2.4.4 TERMINAÇÕES QUE CORRESPONDERIAM A VERBOS DE TERCEIRA CONJUGAÇÃo EM QUE O $U$ É SEMIVOGAL

1. -argüir (2) para argüir e redargüir, com a tônica no - $u$ - nas formas que seriam rizotônicas, como descrito em -uir

2. -ingüir (1) para o verbo único desmilingüir-se, que na tábua se conjuga com o - $u$ - átono em todas as formas

3. -inqüir (1) para delinqüir, com o - $u$-átono em todas as formas e também com - $u$ - tônico nas formas que seriam rizotônicas, como descrito em -uir

4. -orqüir (1) para retorqüir, que na tábua não se conjuga na $1^{\mathrm{a}}$ p.s. pres.ind. e pres.subj.

\subsubsection{TERMINAÇÕES QUE CORRESPONDERIAM A VERbos DE TERCEIRA CONJUGAÇÃo EM QUE O $U$ É COMPONENTE DE DÍGRAFO}

1. -inquir (1) para relinquir (“deixar, abandonar, renunciar”), que na tábua não se conjuga na $1^{\mathrm{a}}$ p.s.pres.ind.

2. -oquir (1) para moquir (com remissão para comer), que na tábua se conjuga apenas nas formas arrizotônicas

3. -osquir (1) para mosquir (com remissão para comer), que na tábua se conjuga apenas nas formas arrizotônicas

4. -uquir (1) para suquir (“ $P[\ldots]$ ingerir alimento(s); comer”), que na tábua se conjuga apenas nas formas arrizotônica

5. -usquir (1) para susquir-se ("TRM [...] retirar-se apressadamente, safar-se, pirar"), que na tábua se conjuga apenas nas formas arrizotônicas

\subsubsection{TERMinaÇões QUe CORRESPONDERIAM A VERBos FósSEIS OU POUCO USADOS}

1. - -ager (1) para trager ("ant." com remissão para trazer), que na tábua vem com a observação "Forma antiga não conjugável pelos padrões atuais"

2. -exir (1) para exir ("ir para fora; sair"), que na tábua veêm com a observação "Forma antiga não conjugável pelos padrões atuais"

3. -ipir (1) para chipir (“tocar com a mão ou exercer pressão manual sobre; apertar, apalpar, que na tábua vem com a observação "Verbo não conjugado por apresentar peculiriadesde morfossintáticas do falar de Cabo Verde" 
4. -oir (1) para abrigoir ("ter contenda com alguém; disputar"), que na tábua vem com a observação "Forma antiga não conjugável pelos padrões atuais"

5. -oler (1) para eqüipoler (“ser eqüipolente a ou entre si; equivaler"), que na tábua vem com a observação "Forma antiga não conjugável pelos padrões atuais"

6. -ulcir (1) para demulcir ("p.us. [...] tornar mole ou macio, molificar; tornar laxo"), que na tábua não se conjuga na $1^{\mathrm{a}}$ p.s.sing. do pres. ind. e em todo o pres. subj.

7. -uxir (2) para cuxir (com remissão para pilar, "moer ou pisar (algo) no pilão"), e kuxir (com remissão para cuxir), que na tábua vêm com a observação "Verbo não conjugado por apresentar peculiriadesde morfossintáticas do falar de Cabo Verde" 


\section{APÊNDICE 3}

\section{TerminaÇões QUaNTIFICADAS POR GRUPOS DE INTERESSE}

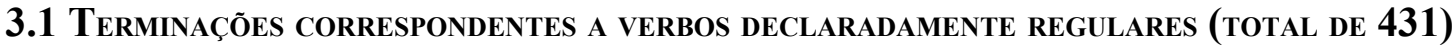

\begin{tabular}{|c|c|c|c|c|}
\hline $1^{\text {a }}$ CONJ. & 35.-alpar & 70.-armar & 105.-eixar & 140.-idar \\
\hline 1. -abar & 36.-alrar & 71.-arnar & 106.-ejar & 141.-idrar \\
\hline 2. -acar & 37.-alsar & 72.-arpar & 107.-elhar & 142.-ifar \\
\hline 3. -açar & 38.-altar & 73.-arrar & 108.-emar & 143.-ifrar \\
\hline 4. -achar & 39.-alvar & 74.-artar & 109.-embrar & 144.-igar \\
\hline 5. -acrar & 40.-amar & 75.-arvar & 110.-empar & 145.-iglar \\
\hline 6. -actar & 41.-ambar & 76.-asar & 111.-emplar & 146.-igmar \\
\hline 7. -adar & 42.-amblar & 77.-ascar & 112.-enar & 147.-ignar \\
\hline 8. -adrar & 43.-ambrar & 78.-asgar & 113.-encar & 148.-ijar \\
\hline 9. -afar & 44.-ampar & 79.-asmar & 114.-ençar & 149.-ilar \\
\hline 10.-agar & 45.-anar & 80.-asnar & 115.-endar & 150.-ilchar \\
\hline 11.-agnar & 46.-ancar & 81.-aspar & 116.-endrar & 151.-ildar \\
\hline 12.-agrar & 47.-ançar & 82.-assar & 117.-engar & 152.-ilhar \\
\hline 13.-aiar & 48.-anchar & 83.-astar & 118.-enhar & 153.-ilmar \\
\hline 14.-aibrar & 49.-andar & 84.-astrar & 119.-ensar & 154.-ilrar \\
\hline 15.-aidar & 50.-andrar & 85.-atar & 120.-entrar & 155.-iltar \\
\hline 16.-aigar & 51.-angar & 86.-atrar & 121.-eptar & 156.-iltrar \\
\hline 17.-ailar & 52.-angrar & 87.-audar & 122.-erar & 157.-ilvar \\
\hline 18.-aimar & 53.-anhar & 88.-aular & 123.-erbar & 158.-imar \\
\hline 19.-ainar & 54.-anjar & 89.-aurar & 124.-estar & 159.-imbar \\
\hline 20.-aipar & 55.-ansar & 90.-ausar & 125.-estrar & 160.-impar \\
\hline 21.-airar & 56.-antar & 91.-autar & 126.-etar & 161.-inar \\
\hline 22.-airrar & 57.-anzar & 92.-avar & 127.-etrar & 162.-incar \\
\hline 23.-aitar & 58.-apar & 93.-avrar & 128.-eudar & 163.-inçar \\
\hline 24.-aivar & 59.-aptar & 94.-axar & 129.-eumar & 164.-inchar \\
\hline 25.-aixar & 60.-arar & 95.-azar & 130.-eusar & 165.-indar \\
\hline 26.-ajar & 61.-arbar & 96.-ebar & 131.-evar & 166.-indrar \\
\hline 27.-alar & 62.-arcar & 97.-eglar & 132.-exar & 167.-infar \\
\hline 28.-alcar & 63.-arçar & 98.-egmar & 133.-ezar & 168.-inflar \\
\hline 29.-alçar & 64.-archar & 99.-eijar & 134.-ibar & 169.-ingar \\
\hline 30.-aldar & 65.-ardar & 100.-eimar & 135.-iblar & 170.-ingrar \\
\hline 31.-alfar & 66.-arfar & 101.-einar & 136.-icar & 171.-inguar \\
\hline 32.-algar & 67.-argar & 102.-eirar & 137.-içar & 172.-inhar \\
\hline 33.-alhar & 68.-arjar & 103.-eitar & 138.-ichar & 173.-instar \\
\hline 34.-almar & 69.-arlar & 104.-eivar & 139.-iclar & 174.-intrar \\
\hline
\end{tabular}




\begin{tabular}{|c|c|c|c|c|}
\hline 175.-inzar & 222.-oldar & 269.-orvar & 316.-umbar & 8. -emer \\
\hline 176.-ipar & 223.-olfar & 270.-osar & 317.-umbrar & 9. -encer \\
\hline 177.-ipsar & 224.-olgar & 271.-oscar & 318.-unar & 10.-encher \\
\hline 178.-irar & 225.-olhar & 272.-osmar & 319.-uncar & 11.-ender \\
\hline 179.-irmar & 226.-olmar & 273.-osnar & 320.-unçar & 12.-enzer \\
\hline 180.-irpar & 227.-olpar & 274.-ossar & 321.-unchar & 13.-erger \\
\hline 181.-irrar & 228.-olsar & 275.-ostar & 322.-undar & 14.-erver \\
\hline 182.-isar & 229.-oltar & 276.-ostrar & 323.-unfar & 15.-exer \\
\hline 183.-iscar & 230.-olvar & 277.-otar & 324.-ungar & 16.-iger \\
\hline 184.-isgar & 231.-omar & 278.-oucar & 325.-unhar & 17.-iver \\
\hline 185.-islar & 232.-ombar & 279.-ouçar & 326.-untar & 18.-ofrer \\
\hline 186.-ismar & 233.-ombrar & 280.-oudar & 327.-unzar & 19.-olher \\
\hline 187.-isnar & 234.-ompar & 281.-oujar & 328.-upar & 20.-olver \\
\hline 188.-ispar & 235.-omprar & 282.-oular & 329.-uprar & 21.-omer \\
\hline 189.-issar & 236.-onar & 283.-oupar & 330.-urar & 22.-omper \\
\hline 190.-istar & 237.-oncar & 284.-ourar & 331.-urbar & 23.-onder \\
\hline 191.-istrar & 238.-onçar & 285.-ousar & 332.-urcar & 24.-orcer \\
\hline 192.-itar & 239.-onchar & 286.-outar & 333.-urçar & 25.-order \\
\hline 193.-itmar & 240.-ondar & 287.-ouvar & 334.-urchar & 26.-orrer \\
\hline 194.-itrar & 241.-ongar & 288.-ouxar & 335.-urdar & 27.-orver \\
\hline 195.-ivar & 242.-onhar & 289.-ovar & 336.-urgar & 28.-oser \\
\hline 196.-ivrar & 243.-onjar & 290.-oxar & 337.-urlar & 29.-over \\
\hline 197.-ixar & 244.-onrar & 291.-ozar & 338.-urmar & $3^{\mathrm{a}}$ CONJ. \\
\hline 198.-izar & 245.-onsar & 292.-uar & 339.-urnar & 1. -abrir \\
\hline 199.-oar & 246.-onstar & 293.-ubar & 340.-urpar & 2. -acir \\
\hline 200.-obar & 247.-onstrar & 294.-ublar & 341.-urrar & 3. -adir \\
\hline 201.-obstar & 248.-ontar & 295.-ubrar & 342.-ursar & 4. -agir \\
\hline 202.-ofar & 249.-ontrar & 296.-ucar & 343.-urtar & 5. -angir \\
\hline 203.-ofrar & 250.-onzar & 297.-uçar & 344.-urvar & 6. -anir \\
\hline 204.-ogar & 251.-opar & 298.-uchar & 345.-usar & 7. -antir \\
\hline 205.-ograr & 252.-oplar & 299.-ucrar & 346.-uscar & 8. -anzir \\
\hline 206.-oiar & 253.-oprar & 300.-udar & 347.-usgar & 9. -apir \\
\hline 207.-oiçar & 254.-optar & 301.-ufar & 348.-usmar & 10.-ardir \\
\hline 208.-oidar & 255.-orar & 302.-uflar & 349.-ustar & 11.-artir \\
\hline 209.-oifar & 256.-orcar & 303.-ugar & 350.-ustrar & 12.-arzir \\
\hline 210.-oilar & 257.-orçar & 304.-ugnar & 351.-utar & 13.-asnir \\
\hline 211.-oimar & 258.-orchar & 305.-uiar & 352.-uvar & 14.-atir \\
\hline 212.-oinar & 259.-ordar & 306.-uidar & 353.-uxar & 15.-ibir \\
\hline 213.-oirar & 260.-orgar & 307.-ujar & $2^{\mathrm{a}}$ CONJ. & 16.-idir \\
\hline 214.-oisar & 261.-orjar & 308.-ular & 1. -amber & 17.-igir \\
\hline 215.-oitar & 262.-orlar & 309.-ulcar & 2. -arder & 18.-igrir \\
\hline 216.-oivar & 263.-ormar & 310.-ulgar & 3. -arrer & 19.-ilir \\
\hline 217.-oixar & 264.-ornar & 311.-ulhar & 4. -ascer & 20.-imir \\
\hline 218.-ojar & 265.-orpar & 312.-ulpar & 5. -eber & 21.-implir \\
\hline 219.-olar & 266.-orrar & 313.-ulsar & 6. -eder & 22.-indir \\
\hline 220.-olcar & 267.-orsar & 314.-ultar & 7. -eger & 23.-ingir \\
\hline 221.-olçar & 268.-ortar & 315.-umar & & \\
\hline
\end{tabular}


24.-inguir

25.-inir

26.-irir

27.-istir

28.-itir 29.-itrir

30.-udir

31.-ugir

32.-ujir

33.-ulgir 34.-ulpir

35.-umbir

36. -umir

37.-umprir

38.-undir

39.-ungir 40.-unir

41.-uprir

42.-urdir

43.-urgir

44.-urtir 45.-urzir

46.-ustir

47.-utir

48.-utrir

49.-uzir 


\subsection{TeRMinaÇões CORRESPONDENTES A VERbOS DECLARADAMENTE ABUNDANTES, CO-REGULARES, DEFECTIVOS E IRREGULARES (TOTAL DE 23)}

\begin{tabular}{|c|c|c|c|}
\hline DEFECTIVOS & 5. -arir & IRREGULARES & -ender \\
\hline 1. -anquir & 6. -arnir & 1. -iar & -enzer \\
\hline 2. -arpir & 7. -emir & 2. -uspir & ABUNDANTES NO \\
\hline 3. -arrir & 8. -iger & IRREGULARES E CO- & PARTICÍPIO \\
\hline тIDOs сомо & 9. -oer & REGULARES & 1. -imir \\
\hline DEFECTIVOS & DEFECTIVOS & 1. -ear & IRREGULARES E \\
\hline 1. -agir & REGULARIZADOS & CO-REGULARES & ABUNDANTES NO \\
\hline 2. -amir & 1. -arcir & 1. -air & PARTICÍPIO \\
\hline 3. -andir & 2. -argir & & 1. -ergir \\
\hline 4. -anquir & 3. -aurir & PARTICÍPIO & \\
\hline
\end{tabular}

\subsection{Terminações de baixa ocorrênCIa (TOTAL de 124)}

\begin{tabular}{ll}
\multicolumn{1}{l}{1 veRBo } \\
1. & -abir \\
2. & -aer \\
3. & -aidar \\
4. & -ailar \\
5. & -airrar \\
6. & -anquir \\
7. & -anter \\
8. & -antir \\
9. & -apir \\
10. & -arcir \\
11. & -arder \\
12. & -arpir \\
13. & -asnir \\
14. & -atir \\
15. & -eglar \\
16. & -egrir \\
17. & -emplar \\
18. & -enhir \\
19. & -equir \\
20. & -ercer \\
21. & -errir \\
22. & -erzir \\
23. & -escrer \\
24. & -esdar
\end{tabular}

25. -esler
26. - -eumar
27. -extar
28. -iblar
29. - -iclar
30. -iger
31. - -iglar
32. -igrir
33. -instar
34. - -itmar
35. -obstar
36. -obvir
37. -oclar
38. -odrir
39. -olpar
40. -ondir
41. -onir
42. -onstar
43. -onstrar
44. -onter
45. -onvir
46. -orchar
47. -orlar
48. -osmar
49. -osnar
50. -ossir

51. -ostir

52. -ovir

53. -ubir

54. -ucrar

55. - unver

56. -uprar

57. -urchar

58. -urlar

59. -urzir

60. -usgar

61. -usmar

62. -uster

2 VERBOS

1. -agnar

2. -alfar

3. -amir

4. -anguir

5. -argir

6. -arjar

7. -arrer

8. -arzir

9. -asir

10. -egmar

11. -eguar

12. -eifar
13. -eltrar
14. -enzer
15. -equar
16. -erder
17. -erlar
18. -esclar
19. -espir
20. -eudar
21. -exer
22. -igmar
23. -ilrar
24. -iltrar
25. -ilvar
26. -implir
27. -inflar
28. -ingrar
29. -inquar
30. -islar
31. -isnar
32. -ivrar
33. -obter
34. -ofrer
35. -oidar
36. -oifar
37. -olçar
38. -olvar
39. -omprar
40. -onjar
41. -onrar
42. -onsar
43. -oplar
44. -optar
45. -order
46. -orgar
47. -orpar
48. -orquir
49. -orrir
50. -orsar
51. -ortir
52. -oudar
53. -ouvar
54. -ucir
55. -ujir
56. -umprir
57. -unzar
58. -urçar
59. -urmar
60. -urpar
61. -uspir
62. -ustir 


\subsection{TERMINAÇÕES CORRESPONDENTES A VERBOS SIMPLESMENTE CLASSIFICADOS COMO REGULARES (TOTAL DE 182)}

\begin{tabular}{|c|c|c|c|c|}
\hline 1 $^{\mathrm{a}}$ CONJ. & 37. -armar & 74. -iltar & 111.-onrar & 148.-usmar \\
\hline 1. -abar & 38. -arnar & 75. -iltrar & 112.-onsar & 149.-ustar \\
\hline 2. -achar & 39. -arpar & 76. -ilvar & 113.-onstar & 150.-utar \\
\hline 3. -acrar & 40. -arrar & 77. -imar & 114.-onstrar & 151.-uxar \\
\hline 4. -adar & 41. -artar & 78. -imbar & 115.-ontar & $2^{\mathrm{a}}$ CONJ. \\
\hline 5. -adrar & 42. -arvar & 79. -impar & 116.-ontrar & 1. -amber \\
\hline 6. -afar & 43. -asar & 80. -inchar & 117.-onzar & 2. -arder \\
\hline 7. -agrar & 44. -asnar & 81. -indar & 118.-ubar & 3. -arrer \\
\hline 8. -ajar & 45. -aspar & 82. -indrar & 119.-ublar & 4. -encher \\
\hline 9. -alar & 46. -assar & 83. -infar & 120.-ubrar & 5. -iver \\
\hline 10. -aldar & 47. -astrar & 84. -inflar & 121.-ucrar & 6. -omper \\
\hline 11. -alfar & 48. -atar & 85. -ingrar & 122.-ufar & 7. -onder \\
\hline 12. -almar & 49. -atrar & 86. -instar & 123.-uflar & \\
\hline 13. -alpar & 50. -avar & 87. -intrar & 124.-ulpar & $\begin{array}{l}3^{\mathrm{a}} \text { CONJ. } \\
1\end{array}$ \\
\hline 14. -alrar & 51. -avrar & 88. -inzar & 125.-ulsar & 1. -antir \\
\hline 15. -alsar & 52. -azar & 89. -ipar & 126.-ultar & 2. -anzir \\
\hline 16. -altar & 53. -embrar & 90. -irar & 127.-umbar & 3. -ardir \\
\hline 17. -alvar & 54. -empar & 91. -irmar & 128.-unchar & $\begin{array}{l}\text { 4. -artir } \\
5\end{array}$ \\
\hline 18. -ambar & 55. -emplar & 92. -irpar & 129.-undar & $\begin{array}{l}\text { J. -arzir } \\
6 \text {-idir }\end{array}$ \\
\hline 19. -amblar & 56. -endar & 93. -irrar & 130.-unfar & 6. -idir \\
\hline 20. -ambrar & 57. -endrar & 94. -isar & 131.-untar & \%. -igrir \\
\hline 21. -ampar & 58. -ensar & 95. -islar & 132.-unzar & $\begin{array}{l}\text { 8. - -ilir } \\
\text { 0 }\end{array}$ \\
\hline 22. -anchar & 59. -entrar & 96. -ismar & 133.-upar & 9. -indir \\
\hline 23. -andar & 60. -ibar & 97. -isnar & 134.-uprar & 10.-inir \\
\hline 24. -andrar & 61. -iblar & 98. -ispar & 135.-urar & $\begin{array}{l}11 .- \text { IrII } \\
12 \text { istix }\end{array}$ \\
\hline 25. -angrar & 62. -ichar & 99. -istar & 136.-urbar & $\begin{array}{l}\text { 12.-istır } \\
13 \text {-itir }\end{array}$ \\
\hline 26. -anjar & 63. -iclar & 100.-istrar & 137.-urchar & $14 .-1 t 1 r$ \\
\hline 27. -ansar & 64. -idrar & 101.-itrar & 138.-urdar & $14 .-$ ujIr \\
\hline 28. -antar & 65. -ifar & 102.-ivar & 139.-urlar & 15.-uIpIr \\
\hline 29. -anzar & 66. -ifrar & 103.-ivrar & 140.-urmar & 16.-umprir \\
\hline 30. -apar & 67. -iglar & 104.-ombar & 141.-urnar & 1/.-undir \\
\hline 31. -arbar & 68. -ijar & 105.-ombrar & 142.-urpar & 18.-uprir \\
\hline 32. -archar & 69. -ilar & 106.-ompar & 143.-urrar & 19.-urdir \\
\hline 33. -ardar & 70. -ilchar & 107.-omprar & 144.-ursar & 20. -urtIr \\
\hline 34. -arfar & 71. -ildar & 108.-onchar & 145.-urtar & 21. -urzir \\
\hline 35. -arjar & 72. -ilmar & 109.-ondar & 146.-urvar & 22. -ustir \\
\hline 36. -arlar & 73. -ilrar & 110.-onjar & 147.-usar & 24.-utrir \\
\hline
\end{tabular}

3.5 TeRMinaÇões CORRESPONDENTES EXCLUSIVAMENTE A DERIVAdOS DE VERBOS MONOSSILÁbICOS (TOTAL DE 12)

$\begin{array}{lllllll}\text { CRER } & \text { 1. } & \text {-escrer } & \text { DAR } & 1 . & \text {-esdar }\end{array}$ 


$\begin{array}{rrrrr}\text { 1. -esler } & \text { 2. -obter } & \text { VER } & \text { 1. - -evir } & \text { 4. -ovir } \\ \text { TER } & \text { 3. -onter } & \text { 1. - -unver } & \text { 2. -obvir } & \\ \text { 1. - anter } & \text { 4. - uster } & \text { VIR } & \text { 3. -onvir }\end{array}$




\subsection{TerminaÇões CORRESPONDENTES A VERbos QUE SEGUEM PARADIGMAS DIFERENTES (TOTAL DE 68)}

\begin{tabular}{ll}
\multicolumn{1}{c}{ 2 PADRõEs } & 14.-audar \\
1. -aber & 15.-aular \\
2. -abrir & 16.-aurir \\
3. -adir & 17.-aver \\
4. -agir & 18.-avir \\
5. -air & 19.-echar \\
6. -alir & 20.-edar \\
7. -andir & 21.-edir \\
8. -anir & 22.-egar \\
9. -arir & 23.-eirar \\
10.-arrir & 24.-eitar \\
11.-asmar & 25.-eler \\
12.-astar & 26.-elhar \\
13.-ater & 27.-ender
\end{tabular}

28. -enir
29. -enzer
30. -erer
31. -ergir
32. -erver
33. -ervir
34. -estar
35. -eter
36. -eusar
37.-ibir
38. -idar
39. -imir
40. -inar
41. -ingir
42. -iscar
43.-ITAR

44. -izar
45. -oder
46.-oer
47.-orir
48.-orrir
49.-ortir
50.-ucar
51.-uçar
52.-uchar
53.-udar
54.-udir
55.-ugir
56.-uir
57.-ular

58.-umar

59.-usar

60.-ustrar

61.-uvar
3 PADRÕES
1. -elir
2. -ever
3. -olir

3.7 TERMinaÇões CORRESPONDENTES A VERBOS COM PARTICULARIDADES SEM RELAÇÃo COM A CONJUGAÇão VERBal (TOTAL DE 18)

\begin{tabular}{|c|c|c|c|}
\hline $\begin{array}{ll} & / \mathrm{x} / \text { ou } / \mathrm{CS} / \\
\text { 1. } & \text {-axar } \\
\text { 2. } & \text {-exar } \\
\text { 3. } & \text {-ixar } \\
\text { 4. } & \text {-oxar }\end{array}$ & $\begin{array}{ll}\text { COM OBSERVAÇ̃̃o DO } & \begin{array}{l}\text { ENCONTRO } \\
\text { CONSONANTAL }\end{array} \\
\text { 1. } & \text {-ectar } \\
2 . & \text {-ectir } \\
\text { 3. } & \text {-egmar } \\
4 . & \text {-eptar }\end{array}$ & $\begin{array}{ll}\text { 5. } & \text {-igmar } \\
6 . & \text {-ignar } \\
7 . & \text {-ipsar } \\
8 . & \text {-itmar } \\
9 . & \text {-obstar } \\
10 . & \text {-optar }\end{array}$ & $\begin{array}{l}\text { 11. - ugnar } \\
\text { SEM OBSERVAÇÃo Do } \\
\text { ENCONTRO } \\
\text { CONSONANTAL } \\
\text { 1. } \\
\text { 2. -actar } \\
\text { 2. } \\
\text { 3. } \\
\text {-agnar } \\
\text {-aptar }\end{array}$ \\
\hline
\end{tabular}

\subsection{TERMinaÇÕES CORRESPONDENTES A VERBOS DA PRIMEIRA CONJUGAÇÃo COM DITONGO NO INFINITIVO (TOTAL DE 56)}

\begin{tabular}{|c|c|}
\hline $\begin{array}{c}\text { COM DESCRIÇÃO DA } \\
\text { PARTICULARIDADE } \\
\text { PRINCIPAL }\end{array}$ & $\begin{array}{l}\text { 13.-eixar } \\
\text { 14. -eudar } \\
\text { 15. -eumar }\end{array}$ \\
\hline 1. -aipar & 16.-eusar \\
\hline 2. -airar & 17. -oiçar \\
\hline 3. -airrar & 18.-oidar \\
\hline 4. -aivar & 19. -oilar \\
\hline 5. -aixar & 20.-oifar \\
\hline 6. -aurar & 21.-oirar \\
\hline 7. -ausar & 22. -oisar \\
\hline 8. -autar & 23.-oitar \\
\hline 9. -eiçar & 24. -oivar \\
\hline 10.-eifar & 25.-oixar \\
\hline 11.-eitar & 26. -ouçar \\
\hline 12.-eivar & 27.-ousar \\
\hline
\end{tabular}

$\begin{gathered}\text { COM NEGAÇÃO DA } \\ \text { PARTICULARIDADE } \\ \text { PRINCIPAL }\end{gathered}$
1. - -audar
2. -eizar
COM DESCRIÇÃO DE
VERBOS COM HIATO
1. -aular
2. -uidar
3. -uitar
SEM DESCRIÇÃO DA
PARTICULARIDADE
PRINCIPAL
1. -aibrar
2. -aigar

3. -ailar

4. -aitar

5. -oudar

6. -oujar

7. -oular

8. -outar

9. -ouvar

10. -ouxar

COM DESCRIÇÃo DE PARTICULARIDADE ADICIONAL

1. -aidar

2. -aimar

3. -ainar

4. -eigar

5. -eijar 
6. -eimar

8. -eirar

10.-oimar

12.-oucar

7. -einar

9. -oiar

11.-oinar

13. -oupar

14. -ourar

3.9 TerminaÇões CoRrespondentes ParCialmente a Verbos da PRIMEIRA CONJUGaÇão COM HIATO NO RADICAL (TOTAL DE 19)

$\begin{array}{llll}\text { COM DESCRIÇÃO DA } & \text { 5. -iscar } & \mathbf{1 0} \text {-uchar } & \text { 16. -ustrar } \\ \text { PARTICULARIDADE } & \text { 6. -itar } & 11 \text {-udar } & \text { 17. -uvar } \\ \text { 1. -ibir } & \text { 7. -izar } & 12 . \text {-ular } & \text { SEM DESCRIÇão DA } \\ \text { 2. -idar } & 8 . \text {-ucar } & \mathbf{1 3} \text {-umar } & \text { PARTICULARIDADE } \\ \text { 3. -inar } & 9 . \text {-uçar } & 14 . \text {-unar } & \text { 1. -ulhar } \\ \text { 4. -inhar } & & 15 . \text {-unir } & \text { 2. -usar }\end{array}$

\subsection{TERMINAÇões CORRESPONDENTES A VERBOS DE PRIMEIRA E SEGUNDA CONJUGAÇÕES COM} ALTERNÂNCIA INSUFICIENTEMENTE DESCRITA (TOTAL DE 20)

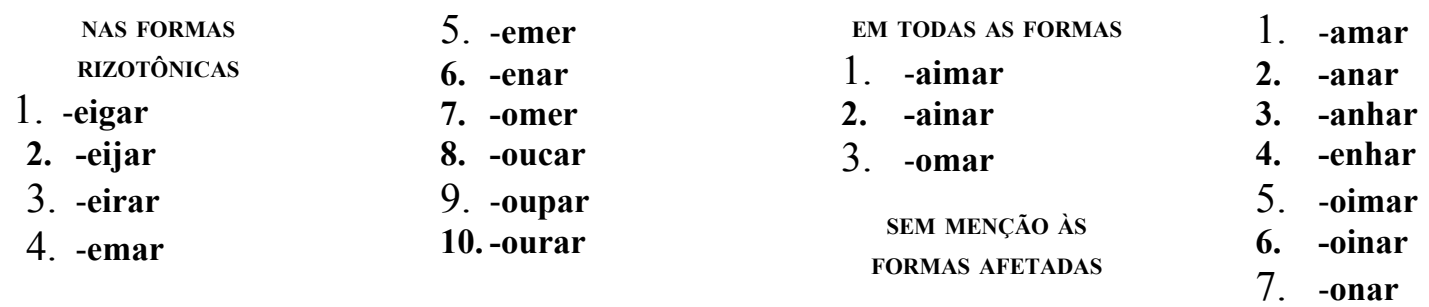

\section{11 TeRminaÇões CORRESPONDENTES A VERBOS de PRIMEIRA E SEGUNDA CONJUGaÇões} EXCLUSIVAMENTE COM DISCORDÂNCIA GRÁFICA (TOTAL DE 49)

\begin{tabular}{|c|c|c|c|}
\hline DECLARADA REGULAR & 14. -unçar & 7. -algar & 21. -igar \\
\hline SEM RESTRIÇÃO & 15. -ungar & 8. -ancar & 22. -incar \\
\hline 1. -encer & 16. -urcar & 9. -ançar & 23. -inçar \\
\hline 2. -iger & 17. -urçar & 10. -angar & 24. -ingar \\
\hline 3. -oiçar & 18. -urgar & 11. -arcar & 25. -iscar \\
\hline $\begin{array}{l}\text { 4. -oncar } \\
\text { 5. -onçar }\end{array}$ & $\begin{array}{l}\text { 19. -uscar } \\
\text { 20. -usgar }\end{array}$ & 12. -arçar & 26. -isgar \\
\hline 6. -ongar & & 13. -argar & DESCRITA SEM \\
\hline 7. -ouçar & $\begin{array}{l}\text { DECLARADA REGULAR } \\
\text { COM RESTRIÇÃO }\end{array}$ & 14. -ascar & INFERÊNCIA DE NÃO- \\
\hline 8. -ucar & 1. -acar & 15. -asgar & 1. -eicar \\
\hline 9. -uçar & 2. -açar & 10. -encar & \\
\hline 10. -ugar & 3. -agar & 1\%. -ençar & $\begin{array}{l}\text { DESCRITA COM } \\
\end{array}$ \\
\hline $\begin{array}{l}\text { 11. -ulcar } \\
\text { 12. -ulgar }\end{array}$ & 4. -aigar & $\begin{array}{l}\text { 18. -engar } \\
\text { 19. -icar }\end{array}$ & $\begin{array}{l}\text { INFERENCIA DE NAO- } \\
\text { REGULARIDADE }\end{array}$ \\
\hline $\begin{array}{l}\text { 12. -ulgar } \\
\text { 13. -uncar }\end{array}$ & $\begin{array}{ll}\text { 5. } & \text {-alcar } \\
6 . & \text {-alçar }\end{array}$ & 20. -içar & 1. -anger \\
\hline
\end{tabular}




\subsection{TERMINAÇÕES CORRESPONDENTES A VERBOS DE PRIMEIRA E SEGUNDA CONJUGAÇÕES EXCLUSIVAMENTE COM ALTERNÂNCIA VOCÁLICA (TOTAL DE 105)}

DECLARADA REGULAR
SEM RESTRIÇÃo
1. -eptar
2. -estar
3. -eter
4. -ever
5. -exer
6. -obstar
7. -ochar
8. -oclar
9. -odar
10. -ofrer
11. -ograr
12. -oldar
13. -olhar
14. -olher
15. -olmar
16. -olpar
17. -olsar
18. -oltar
19. -olvar
20. -olver
21. -opar
22. -oplar
23. -oprar
24. -optar
25. -orar
26. -orchar
27. -ordar
19

\begin{tabular}{|c|c|}
\hline 28. -order & 2. -eder \\
\hline 29. -orjar & 3. -erar \\
\hline 30. -orlar & 4. -erbar \\
\hline 31. -ormar & 5. -erver \\
\hline 32. -ornar & 6. -estrar \\
\hline 33. -orpar & 7. -etar \\
\hline 34. -orrar & 8. -etrar \\
\hline 35. -orrer & 9. -evar \\
\hline 36. -orsar & 10. -exar \\
\hline 37. -ortar & 11. -ezar \\
\hline 38. -orvar & 12. -obar \\
\hline 39. -orver & 13. -oer \\
\hline 40. -osar & 14. -ofar \\
\hline 41. - oser & 15. -ofrar \\
\hline 42. -osmar & 16. -oiar \\
\hline 43. -osnar & 17. -ojar \\
\hline 44. -ossar & 18. -olar \\
\hline 45. -ostar & 19. -olfar \\
\hline 46. -ostrar & DESCRITA SEM \\
\hline 47. -otar & INFERÊNCIA DE NÃO- \\
\hline 48. -ovar & REGULARIDADE \\
\hline 49. -over & 1. -ebar \\
\hline 50. -oxar & 2. -ebrar \\
\hline $\begin{array}{l}\text { 50. -oxar } \\
\text { 51. -ozar }\end{array}$ & 3. -echar \\
\hline & 4. -ecrar \\
\hline 52. -ozer & 5. -ectar \\
\hline $\begin{array}{l}\text { DECLARADA REGULAR } \\
\text { COM RESTRIÇ̃̃o }\end{array}$ & 6. $\quad$-edar \\
\hline 1. -eber & $8 . \quad$-efar \\
\hline
\end{tabular}

9. - eglar

10. -egmar

11. -elar

12. -eler

13. -eltrar

14. -elvar

15. -epar

16. -erdar

17. -erlar

18. -ermar

19. -ernar

20. -errar

21. -ersar

22. -ertar

23. -ervar

24. -esar

25. -esclar

26. -esmar

27. -espar

28. -essar

29. -obrar
DESCRITA COM INFERÊNCIA DE NÃO- REGULARIDADE
1. -erder
2. -erer
3. -erter
4. -extar
5. -oder

\subsection{TerminaÇões CORRespondentes a Verbos de PRimeira e SEgunda CONJUGaÇões COM DISCORDÂNCIA GRÁFICA E ALTERNÂNCIA VOCÁLICA AO MESMO TEMPO (TOTAL DE 26)}

\begin{tabular}{|c|c|c|c|}
\hline $\begin{array}{l}\text { DECLARADA REGULAR } \\
\text { SEM RESTRIÇÃO }\end{array}$ & $\begin{array}{l}\text { DECLARADA REGULAR } \\
\text { COM RESTRIÇÃO }\end{array}$ & $\begin{array}{ll}\text { 2. } & \text {-eçar } \\
3 & \text {-eoar }\end{array}$ & $\begin{array}{l}\text { DESCRITA COM } \\
\text { INFERÊNCIA DE NÃO- }\end{array}$ \\
\hline 1. -erger & 1. -ecer & $\begin{array}{ll}\text { 5. } & \text {-egar } \\
4 & \text {-ercar }\end{array}$ & REGULARIDADE \\
\hline 2. -oçar & 2. -eger & 5 -ercar & 1. -ercer \\
\hline 3. -olçar & 3. -ogar & 6. -ergar & 2. -erguer \\
\hline 4. -orcar & 4. -olcar & 7. -escar & SEM MENÇÃ̃O ÀS \\
\hline 5. -orçar & 5. -olgar & 8. -esgar & PARTICULARIDADES \\
\hline 6. -orcer & DESCRITA SEM & -ocar & MORFOLÓGICAS \\
\hline 7. -orgar & INFERÊNCIA DE NÃO- & & 1. -escer \\
\hline 8. -oscar & REGULARIDADE & & \\
\hline 9. -ouçar & 1. -ecar & & \\
\hline
\end{tabular}




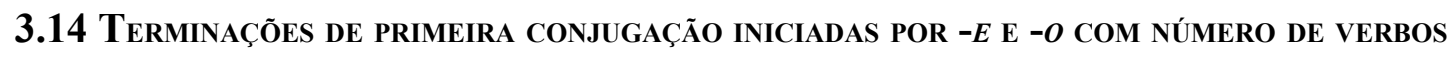
(TOTAL DE VERBOS 4517)

\begin{tabular}{|c|c|c|c|c|}
\hline SEM ALT.VOC. & -egmar (2) & -esar (53) & -oiar (10) & -orjar (8) \\
\hline -ear (1092) & -egnar (2) & -escar (7) & -ojar (22) & -orlar (1) \\
\hline -echar (9) & -egrar (11) & -esclar (2) & -olar (122) & -ormar (19) \\
\hline -egar (5) & -elar (247) & -esgar (6) & -olcar (5) & -ornar (31) \\
\hline -eiar (2) & -eldar (1) & -esmar (7) & -olçar (2) & -orpar (2) \\
\hline -ejar (270) & -elgar (1) & -espar (3) & -oldar (13) & -orrar (297) \\
\hline -elhar (64) & -elhar (1) & -essar (33) & -oldrar (1) & -orsar (2) \\
\hline -oar (261) & -elpar (2) & -estar (67) & -olfar (5) & -ortar (27) \\
\hline -oiar (1) & -eltar (1) & -estrar (13) & -olgar (12) & -orvar (2) \\
\hline & -eltrar (2) & -etar (204) & -olhar (52) & -osar (32) \\
\hline COM ALT.VOC. & -elvar (4) & -etrar (13) & $-\operatorname{olmar}(5)$ & -oscar (10) \\
\hline -ear (L) & -epar (9) & -evar (21) & -olpar (1) & -oslar (1) \\
\hline -ebar (b) & -eptar (3) & -exar (14) & -olsar (5) & -osmar (1) \\
\hline -edrar (15) & $-\operatorname{erar}(151)$ & -ezar (27) & -oltar (6) & -osnar (1) \\
\hline -ecar (55) & -erbar (7) & -obar (19) & -olvar (2) & -ossar (19) \\
\hline -eçar (18) & -ercar (8) & -obrar (15) & -opar (24) & -ostar (26) \\
\hline -eclar (1) & -erçar (3) & -obstar (1) & -oplar (2) & -ostrar (5) \\
\hline -ecrar (3) & -erdar (6) & -ocar (112) & -oprar (5) & $-\operatorname{otar}(113)$ \\
\hline - ectar (14) & -ergar (11) & -oçar (26) & -optar (2) & -otrar (1) \\
\hline -echar (I0) & -erlar (2) & -oclar (1) & -orar $(165)$ & -ovar (26) \\
\hline -edar (45) & -ermar (7) & -ochar (27) & -orcar (15) & -oxar (9) \\
\hline -edrar (10) & -ernar (35) & -odar (24) & -orçar (7) & $\operatorname{-ozar}(7)$ \\
\hline -efar (4) & -errar (33) & -ofar (14) & -orchar (1) & \\
\hline -eflar (1) & -ersar (9) & -ofrar (8) & -ordar (20) & INDEFINIDO \\
\hline -egar (124) & $-\operatorname{ertar}(28)$ & -ogar (30) & $-\operatorname{orfar}(2)$ & -echar (5) \\
\hline -eglar (1) & -ervar (13) & -ograr (5) & -orgar (2) & -extar (1) \\
\hline
\end{tabular}

\subsection{TERminaÇões de SEgunda CONJUGaÇão INICIADAS POR -E E - $O$ COM NÚMERO DE VERboS} (TOTAL DE VERBOS 572)

\begin{tabular}{|c|c|c|c|c|}
\hline COM ALT.VOC. & -erer (8) & -ever (16) & -orber (1) & -ozer (5) \\
\hline -eber (11) & -erger (4) & $-\operatorname{exer}(2)$ & -orcer (6) & \\
\hline -ecer (288) & -erguer (5) & -oder (3) & -order (2) & DEFECTIVOS \\
\hline -eder (17) & -erter (19) & -oer (10) & -orrer $(20)$ & -oler (1) \\
\hline -eger (9) & -erver (2) & -ofrer (2) & -orver (6) & DEFECTIVO $S$ \\
\hline -ercer (1) & -escer (67) & -olher (11) & $-\operatorname{oser}(4)$ & COM ALT.VOC. \\
\hline -erder (2) & -eter (19) & -olver (15) & -over (13) & -eler (2) \\
\hline
\end{tabular}

\subsection{TERMINAÇÕES CORRESPONDENTES A VERBOS DE TERCEIRA CONJUGAÇÃO COM ALTERNÂNCIA VOCÁLICA E SEM DEFECTIVIDADE (TOTAL DE 21)}

\begin{tabular}{|c|c|c|c|}
\hline DESCRITA COM & 5. -ergir & 12. -etir & 19. -umir \\
\hline INFERÊNCIA DE NÃO- & 6. -erir & 13. -obrir & 20. -upir \\
\hline REGULARIDADE & 7. -ertir & 14. -ormir & DECLARADA \\
\hline 1. -ectir & 8. -ervir & 15. -ossir & IRREGULAR \\
\hline 2. - -edir & 9. -erzir & 16. -ubir & 21. -uspir \\
\hline $\begin{array}{ll}\text { 3. } & \text {-egrir } \\
4 & \text {-entir }\end{array}$ & 10. -espir & 17. -udir & \\
\hline 4. -entir & 11. -estir & 18. -ugir & \\
\hline
\end{tabular}




\subsection{TeRminaÇÕES CORRESPONDENTES A VERBoS DE TERCEIRA CONJUGaÇ̃̃o COM DEFECTIVIDAdE E SEM ALTERNÂNCIA VOCÁLICA (TOTAL DE 20)}

\begin{tabular}{|c|c|c|c|}
\hline DESCRITA SEM & 4. -anguir & 11.-iquar & DESCRITA COM \\
\hline INFERÊNCIA DE NÃO- & 5. -ansir & 12. -ondir & INFERÊNCIA DE NÃO- \\
\hline REGULARIDADE & 6. -asir & 13. -ornir & REGULARIDADE \\
\hline 1. -abir & 7. -aver & 14.-ostir & 1. -adir \\
\hline 2. -aldir & 8. -enhir & 15. -ucir & 2. -anir \\
\hline 3. -alir & $\begin{array}{l}\text { 9. -equir } \\
\text { 10. -errir }\end{array}$ & 16. -urir & $\begin{array}{l}\text { 3. -iger } \\
\text { 4. -onir }\end{array}$ \\
\hline
\end{tabular}

\subsection{TERMINAÇões CORRESPONDENTES A VERBOS DE TERCEIRA CONJUGAÇÃO COM ALTERNÂNCIA VOCÁLICA E DEFECTIVIDAdE (TOTAL DE 13)}

\begin{tabular}{|c|c|c|c|c|c|}
\hline DESCRITA SEM & 3. -ernir & & DESCRITA COM & 3 & -olir \\
\hline INFERÊNCIA DE NÃO- & 4. -odir & & FERÊNCIA DE NÃO- & 4 & -orir \\
\hline REGULARIDADE & 5. -odrir & & REGULARIDADE & 5 & -orquir \\
\hline 1. -elir & 6. -ortir & 1 & -eler & 6 & -orrir \\
\hline 2. -enir & & & -ergir & 7 & -ulir \\
\hline
\end{tabular}

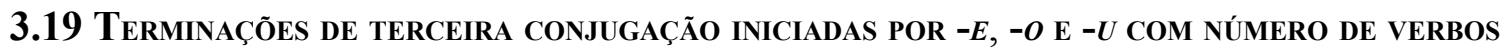 (TOTAL DE VERBOS 4517)}

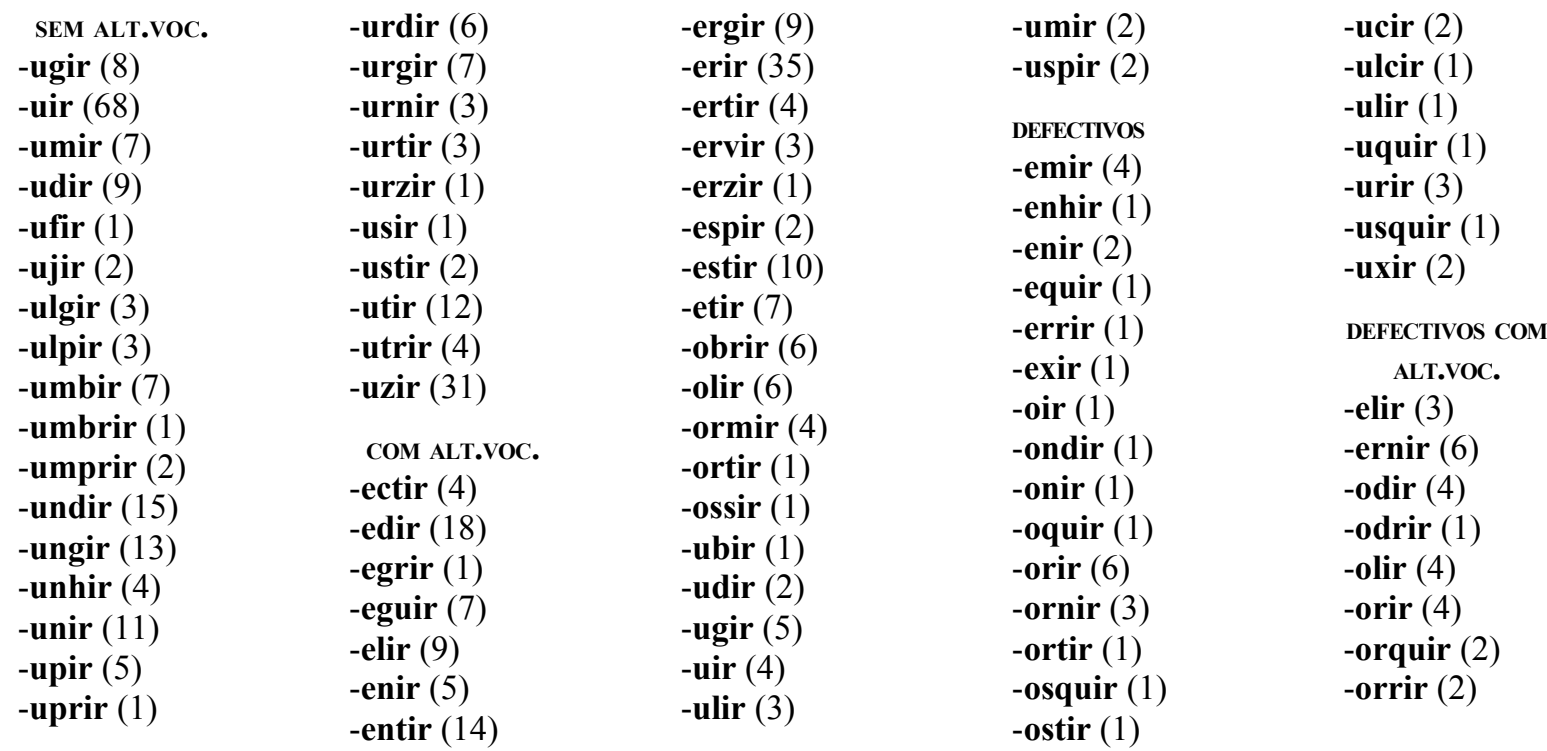

3.20 Verbetes QUe INCLUEM OBSERVAÇões ESTRANHAS À MORFOLOGIA VERbal (TOTAL DE 22)

\begin{tabular}{|c|c|c|c|c|}
\hline 1. -açar & 6. -ecer & 11.-estar & 16.-itar & 21.-unhar \\
\hline 2. -anhar & 7. -ejar & 12.-inhar & 17.-izar & 22. -urir \\
\hline 3. -arar & 8. -enhar & 13. -idar & 18. -onhar & \\
\hline 4. -ear & 9. -entar & 14.-iscar & 19. -orizar & \\
\hline 5. -elir & 10.-escer & 15. -issar & 20.-lhar & \\
\hline
\end{tabular}




\section{APÊnDICE 4}

\section{Modelo de Ficha de CONJUGaÇão Verbal}

Neste Apêndice, apresenta-se a Ficha de conjugação do presente do indicativo, usada nos cursos de português para estrangeiros do Centro de Língua da FFLCH-USP, mas reorganizada de acordo com algumas das constatações feitas neste estudo.

Trata-se de exercícios - nem de uso, nem de fixação, mas de compreensão da estrutura que caracteriza o padrão geral em português, salientando-se as coincidências entre a VT, o SMT e o SNF.

No caso das alternâncias vocálicas - que vem sendo negligenciada em algumas gramáticas voltadas para falantes de português como língua estrangeira -, é necessário que o professor chame atenção para a oposição entre as vogais médias abertas e fechadas (que, nas duas primeiras conjugações, não se manifesta na língua escrita.

No caso dos verbos com alterações no RI de SbPr, que quase sempre se manifestam em 1 IdPr, o agrupamento desses verbos prepara os alunos para, quando do estudo das formas do presente naquele modo, perceber a regularidade nas alterações consonantais e/ou vocálicas.

Como a necessidade imediata dos alunos é a fala, exercitam-se apenas os verbos mais comuns nas formas de 1, 3, 4 e $6 \mathrm{IdPr}$, que ficam representadas pelo pronome sujeito no intuito de minimizar a terminologia técnica, restrita a: radical, vogal da primeira, segunda e terceira conjugações, marca do tempo e marca da pessoa.

Note-se, ainda, que esses exercícios devem ser feitos a partir da consulta das tábuas de conjugação de Ryan (1991), ou de qualquer outro manual de que os alunos dispõem e, de preferência, com o acompanhamento do professor. 


\section{Ficha de ConjugaÇão do PResente do indicativo}

1 Complete o quadro com a vogal característica de cada conjugação, a marca do tempo e a marca da pessoa:

\begin{tabular}{|c|c|c|c|c|c|c|c|c|c|c|c|}
\hline & radical $\mathrm{v} 1^{\mathrm{a}}$ & $\mathrm{T}$ & $\mathrm{P}$ & radical & $\mathrm{v} 2^{\mathrm{a}}$ & $\mathrm{T}$ & $\mathrm{P}$ & radical & $\mathrm{v} 3^{\mathrm{a}}$ & $\mathrm{T}$ & $\mathrm{P}$ \\
\hline & compr & & & vend & & & & divid & & & \\
\hline eu & compr & & & vend & & & & divid & & & \\
\hline ele, ela, você, a gente & compr & & & vend & & & & divid & & & \\
\hline nós & compr & & & vend & & & & divid & & & \\
\hline eles, elas, vocês & compr & & & vend & & & & divid & & & \\
\hline
\end{tabular}

2 Complete o quadro dos verbos com as formas com mudança de grafia na consoante radical para manutenção da pronúncia $(c \rightarrow c, g \rightarrow j$, e $g u \rightarrow g)$ :

\begin{tabular}{|l|c|c|c|}
\cline { 2 - 4 } \multicolumn{1}{c|}{} & pertencer & dirigir & distinguir \\
\hline eu & & & \\
\hline ele, ela, você, a gente & pertence & dirige & distingue \\
\hline nós & pertencemos & dirigimos & distinguimos \\
\hline eles, elas, vocês & pertencem & dirigem & distinguem \\
\hline
\end{tabular}

3 Complete o quadro com as formas dos verbos em -ear e do verbo ler com ditongação na vogal do radical $(e \rightarrow$ $e i)$ :

\begin{tabular}{|l|c|c|}
\cline { 2 - 3 } \multicolumn{1}{c|}{} & passear & ler \\
\hline eu & & \\
\hline ele, ela, você, a gente & & \\
\hline nós & passeamos & lemos \\
\hline eles, elas, vocês & & \\
\hline
\end{tabular}

4 Complete o quadro com as formas dos verbos em -iar com ditongação na vogal do radical $(i \rightarrow e i)$, comparando-as com as formas da maioria dos verbos em -iar (sem mudança no radical):

\begin{tabular}{|l|c|c|c|}
\cline { 2 - 4 } \multicolumn{1}{c|}{} & sem mudança no radical & \multicolumn{2}{c|}{$(i \rightarrow e i)$} \\
\cline { 2 - 4 } \multicolumn{1}{c|}{} & pronunciar & intermediar & odiar \\
\hline eu & pronuncio & & \\
\hline ele, ela, você, a gente & pronuncia & & \\
\hline nós & pronunciamos & intermediamos & odiamos \\
\hline eles, elas, vocês & pronunciam & & \\
\hline
\end{tabular}

5 Complete o quadro com as formas dos verbos da primeira conjugação com vogal $e$ aberta no radical e do verbo querer, comparando-as com as formas de muitos verbos com a vogal $e$ fechada:

\begin{tabular}{|l|c|c|c|}
\cline { 2 - 4 } \multicolumn{1}{c|}{} & vogal $e$ fechada & \multicolumn{2}{c|}{ vogal $e$ aberta } \\
\hline eu & desej & levar & querer \\
\hline ele, ela, você, a gente & desej & & \\
\hline nós & desej & & queremos \\
\hline eles, elas, vocês & desej & levamos & \\
\hline
\end{tabular}


6 Complete o quadro com as formas dos verbos da primeira conjugação com vogal $o$ aberta no radical:

\begin{tabular}{|l|c|}
\cline { 2 - 2 } \multicolumn{1}{l|}{} & morar \\
\hline eu & \\
\hline ele, ela, você, a gente & \\
\hline nós & moramos \\
\hline eles, elas, vocês & \\
\hline
\end{tabular}

7 Complete o quadro com as formas dos verbos da segunda conjugação com vogal $e$ aberta no radical:

\begin{tabular}{|l|c|}
\cline { 2 - 2 } \multicolumn{1}{c|}{} & mexer \\
\hline eu & mexo \\
\hline ele, ela, você, a gente & \\
\hline nós & mexemos \\
\hline eles, elas, vocês & \\
\hline
\end{tabular}

8 Complete o quadro com as formas dos verbos da segunda conjugação com vogal $o$ aberta no radical:

\begin{tabular}{|l|c|}
\cline { 2 - 2 } \multicolumn{1}{l|}{} & correr \\
\hline eu & corro \\
\hline nós ela, você, a gente & \\
\hline eles, elas, vocês & corremos \\
\hline
\end{tabular}

9 Complete o quadro com as formas dos verbos da terceira conjugação com vogal $e$ aberta no radical, prestando atenção na grafia das formas em negrito:

\begin{tabular}{|l|c|c|c|}
\cline { 2 - 4 } \multicolumn{1}{c|}{} & sentir & progredir & servir \\
\hline eu & sinto & progrido & sirvo \\
\hline ele, ela, você, a gente & sente & progride & \\
\hline nós & sentimos & progredimos & servimos \\
\hline eles, elas, vocês & sentem & progridem & \\
\hline
\end{tabular}

10 Complete o quadro com as formas dos verbos da terceira conjugação com vogal $o$ aberta no radical, prestando atenção na grafia das formas em negrito:

\begin{tabular}{|l|c|}
\cline { 2 - 2 } \multicolumn{1}{c|}{} & dormir \\
\hline eu & durmo \\
\hline ele, ela, você, a gente & \\
\hline nós & dormimos \\
\hline eles, elas, vocês & \\
\hline
\end{tabular}

11 Complete o quadro com a forma dos verbos em -uir, com mudança de grafia (com vogal $u$ ou $o$ aberta no radical):

\begin{tabular}{|l|c|c|}
\cline { 2 - 3 } \multicolumn{1}{c|}{} & $u$ & $o$ aberto \\
\hline eu & distribuir & construir \\
\hline ele, ela, você, a gente & distribuo & construo \\
\hline nós & & \\
\hline eles, elas, vocês & distribuem & \\
\hline
\end{tabular}


12 Complete o quadro com as formas de alguns verbos com introdução da vogal $i$ no radical, prestando atenção na grafia das formas em negrito:

\begin{tabular}{|l|c|c|c|c|}
\cline { 2 - 5 } \multicolumn{1}{c|}{} & caber & saber & sair & rir \\
\hline eu & & & & \\
\hline ele, ela, você, a gente & cabe & sabe & sai & ri \\
\hline nós & cabemos & sabemos & saímos & rimos \\
\hline eles, elas, vocês & cabem & sabem & saem & \\
\hline
\end{tabular}

13 Complete o quadro com as formas de alguns verbos com mudança na consoante do radical, prestando atenção na pronúncia das formas em negrito:

\begin{tabular}{|l|c|c|c|c|}
\cline { 2 - 5 } \multicolumn{1}{c|}{} & perder & pedir & poder & ouvir \\
\hline eu & & & & \\
\hline ele, ela, você, a gente & perde & pede & pode & ouve \\
\hline nós & perdemos & pedimos & podemos & ouvimos \\
\hline eles, elas, vocês & perdem & pedem & podem & ouvem \\
\hline
\end{tabular}

14 Complete o quadro com as formas dos verbos em -zer (com ou sem mudança na consoante do radical) e sem marca de pessoa

\begin{tabular}{|l|c|c|c|}
\cline { 3 - 4 } \multicolumn{1}{c|}{} & sem mudança na consoante & \multicolumn{2}{c|}{ com mudança na consoante } \\
\hline eu & produzir & dizer & fazer \\
\hline ele, ela, você, a gente & produzo & & \\
\hline nós & & & \\
\hline eles, elas, vocês & produzimos & dizemos & fazemos \\
\hline
\end{tabular}

15 Complete os quadro com as formas com nasalização da vogal do radical:

\begin{tabular}{|l|c|c|c|c|}
\cline { 2 - 5 } \multicolumn{1}{c|}{} & ter & pôr & ver & vir \\
\hline eu & & & & \\
\hline ele, ela, você, a gente & & & & \\
\hline nós & temos & pomos & vimos & vimos \\
\hline eles, elas, vocês & & & & \\
\hline
\end{tabular}

16 Complete o quadro com as formas dos verbos com mudança de grafia na marca de pessoa (com e sem mudança de radical):

\begin{tabular}{|l|c|c|c|c|}
\cline { 2 - 5 } \multicolumn{1}{c|}{} & \multicolumn{2}{c|}{ sem mudança de radical } & \multicolumn{2}{c|}{ com mudança de radical } \\
\hline \multicolumn{1}{c|}{ dar } & estar & ir & ser \\
\hline eu & & & & \\
\hline nós ela, você & & & & \\
\hline eles, elas, vocês & damos & estamos & vamos & somos \\
\hline
\end{tabular}


16 Complete o quadro com as formas com acento gráfico:

\begin{tabular}{|l|c|c|c|}
\cline { 2 - 4 } \multicolumn{1}{c|}{} & enxaguar & voar & reunir \\
\hline eu & & & \\
\hline ele, ela, você & & & \\
\hline nós & enxaguamos & voamos & reunimos \\
\hline eles, elas, vocês & & & \\
\hline
\end{tabular}


Anexo 1

Quadro Para os SUfixos MOdo-TeMporais nOS Verbos PORTUGUESES (CÂMARA JR., 1975, P. 146)

\begin{tabular}{|c|c|}
\hline$\phi$ & $\begin{array}{l}\text { Indicativo presente } \\
\text { Indicativo pretérito perfeito }- \text { singular e } 1 .^{\mathrm{a}} \text { e } 2 .^{\mathrm{a}} \text { pessoa plural }\end{array}$ \\
\hline $\begin{array}{l}\text { VA (Atono) } \\
\text { IA (/I/ tônico) }\end{array}$ & $\begin{array}{l}\text { Indicativo pretérito imperfeito (1.a conjugação) } \\
\text { Indicativo pretérito imperfeito }\left(2 .^{\mathrm{a}} \text { e } 3 .^{\mathrm{a}} \text { conjugação) }\right.\end{array}$ \\
\hline RA (Átono) & $\begin{array}{l}\text { Indicativo pretérito mais-que-perfeito } \\
\text { Indicativo pretérito perfeito }-3 .^{2} \text { pessoa plural }\end{array}$ \\
\hline $\begin{array}{ll}\text { E } & \text { (Atono) } \\
\text { (Tónico) } \\
\text { A } \\
\text { (Atono) } \\
\text { (Tônico) }\end{array}$ & 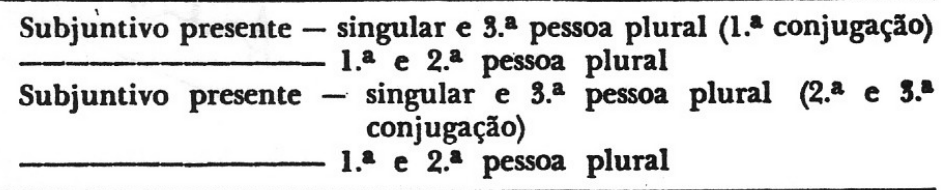 \\
\hline $\begin{array}{l}\text { SSE /SE/ } \\
\text { (Atono) }\end{array}$ & Subjuntivo pretérito \\
\hline $\mathbf{R}$ & $\begin{array}{l}\text { Suhjuntivo futuro } \\
\text { Infinitivo }\end{array}$ \\
\hline $\begin{array}{l}\text { RE (Tónico) } \\
\text { RA }-\end{array}$ & $\begin{array}{c}\text { Indicativo futuro do presente }-2 .^{\mathrm{a}} \text { pessoa plural, } 1 .^{\mathrm{a}} \text { pessoa } \\
\text { singular plural } \\
2 .^{\mathrm{a}} \text { pessoa singular, } 3 .^{2} \mathrm{sin}- \\
\text { gular e plural }\end{array}$ \\
\hline \multicolumn{2}{|c|}{ RIA (/I/ tónico) Indicativo futuro do pretérito } \\
\hline NDO /(N)DU/ & Gerúndio \\
\hline DO & Particípio perfeito \\
\hline
\end{tabular}


Anexo 2

Quadro Para os Sufixos NúMero-Pessoais nos Verbos PORTUGUeSes (CÂMara JR, 1975, P. 147)

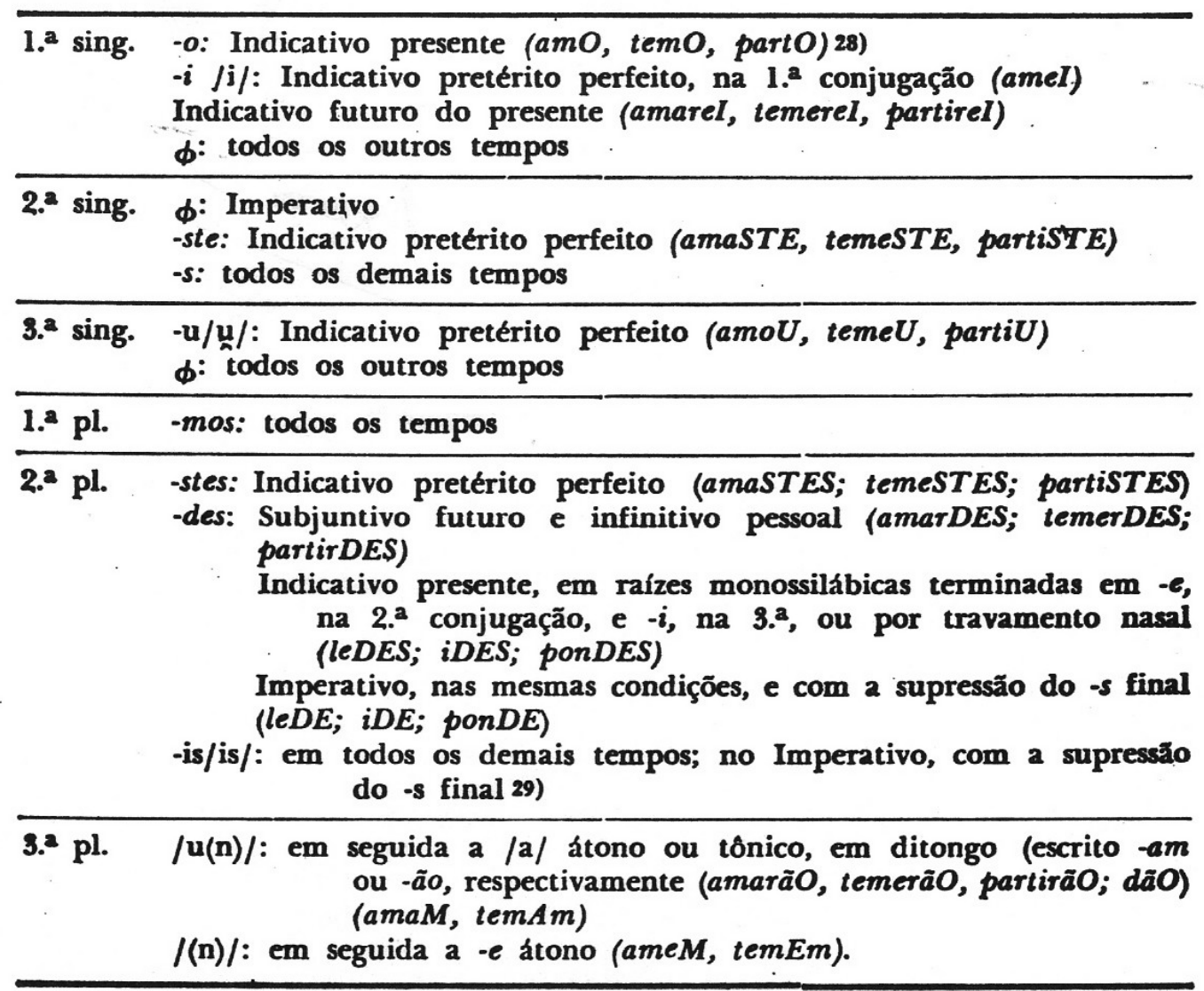

